ELISA BAND

CRIAÇÃO COM COLETIVOS HETEROGÊNEOS

São Paulo

2020 



\title{
ELISA BAND
}

\section{CRIAÇÃO COM COLETIVOS HETEROGÊNEOS}

\author{
(versão corrigida)
}

Dissertação apresentada à Escola de Comunicação e Artes da Universidade de São Paulo para obtenção do título de mestre em Artes Cênicas

Área de concentração: Teoria e Prática do Teatro

Orientador: Prof. Dr. Antônio Carlos de Araújo Silva

São Paulo

2020 
Autorizo a reprodução e divulgação total ou parcial deste trabalho, por qualquer meio convencional ou eletrônico, para fins de estudo e pesquisa, desde que citada a fonte.

Catalogação na Publicação Serviço de Biblioteca e Documentaçäo

Escola de Comunicaçöes e Artes da Universidade de Säo Paulo Dados inseridos pelo(a) autor(a)

Band, Bliess

Criaç̄o con coletivos heterogeneos / Bliea Band; orientador, Ant8nio Carloe de Arajjo Silva. -- Säo Paulo, 2020 .

204 p.: il.

Dinzertação (Mentrado) - Programa de P6a-Graduação em Arten Cenican - Becola de Comunicaçóen e Arten / Univeraidade de Sĩo Paulo.

Bibliografia

Verašo original

1. Teatro Contefporaneo 2. Performance 3. Coletivos Heterogeneon 4. Arte e Clinica I. de Aralijo Silva, Antônio Carloe II. Titulo.

CDD 21.ed. - 792 
BAND, Elisa. Criação com coletivos heterogêneos. Dissertação apresentada à Escola de Comunicação e Artes da Universidade de São Paulo para obtenção do título de mestre em Artes Cênicas.

\section{BANCA EXAMINADORA}

Orientador: Prof. Dr. Antônio Carlos de Araújo Silva Universidade de São Paulo

Profa. Dra. Christine Greiner

Pontifícia Universidade Católica de São Paulo

Prof. Dr. Peter Pál Pelbart

Pontifícia Universidade Católica de São Paulo

Aprovada em: de de 2020. 

Dedico ao Samuel pelo amor, pela afinidade de mundos e pelo companheirismo fundamental nesta dissertação e na vida.

E à minha família, Nica, Sylvio, Ayala, Sacha e Lucia, pelo afeto diário e reinventado. 



\section{Agradecimentos}

A meu orientador, Antônio Carlos de Araújo. Com generosidade, inteligência e olhar minucioso, confiou em mim e propiciou a abertura de caminhos na escrita, no pensamento e na criação.

A Sílvia Fernandes e Peter Pál Pelbart, que no exame de qualificação corrigiram a rota de um modo que foi um alívio e um estímulo. E bem antes, pelos aprendizados afetivos e estéticos. Silvinha, por confiar em mim quando nem eu acreditava muito. Peter, pela amizade e abertura para que pudéssemos construir novas proximidades.

A Tatiana Filinto, Ana Dugaich, Carol Rodrigues, Fernanda Machado, Felipe Arruda, Marcílio Godoy, Júlia Rosemberg, pelo alinhavo dessa rede afetiva e criativa com tanta delicadeza.

A Luana Chnaiderman, pelo diálogo e leitura de várias partes do texto, pela amizade cuidadosa e verdadeira, neste trabalho e na vida.

A Renan Marcondes, pela interlocução amorosa e criativa, que abre pensamentos, danças e invenções.

A Laís Barreto, pelas afinidades, conversas, amizade inspiradora e cuidadosa, e trocas tão frutíferas na arte e na vida.

A Erin Manning, pelos nossos encontros e pela tarde de conversa sobre belezas discordantes e sabores que explodem dentro da boca. A Francisco Trento, pelo incentivo e insistência para eu falar com a Erin.

Aos colegas de orientação, pela amizade, pelas afinidades e contribuições para a pesquisa. Nossas reuniões mensais me ensinaram tanto, essa pesquisa tem um pouco de cada um de vocês: Alberto Villarreal, Camila Moreira, Diego Moschkovich, Eder Asa, Francis Wilker, João Bernardo Caldeira, Murilo Gaulês, Rafael Bicudo e Vinícius Meloni.

A Cássio Santiago, pela parceria frutífera em parte desta trajetória.

A Cristine Peron e Arnaldo de Melo pelas descobertas inaugurais e a amizade.

A Marli Barros e ao professor José Aury Cunha pelo carinho e prontidão nas ajudas geográficas e filosóficas.

A Rachel Brumana, Andreia Duarte e Lili Monteiro, pelos momentos divertidos e inspiradores que passamos juntas.

A Tamara Elizabeth Cury Sciré, pela eficiência e gentileza.

À Universidade de São Paulo e ao Programa de Pós-Graduação em Artes Cênicas da ECA/USP, seu corpo docente, discente e funcionários. Também agradeço ao Programa de Aperfeiçoamento ao Ensino (PAE) da USP pela bolsa de supervisão de estágio.

À Capes, pela concessão da bolsa de mestrado e pelo apoio financeiro para a realização desta pesquisa. 
Aos professores Julia Guimarães Mendes, Marcos Bulhões, Marcelo Denny (in memoriam), Artur Matuck e Luís Fernando Ramos, pelo espaço de criação e investigação.

As instituições, fotógrafos e fotógrafas que cederam as fotos utilizadas nesta dissertação: Programa Igual Diferente, MAM - SP, Karina Bacci, Ser em Cena, Fabio Barrocal, Luiz Dávila/ Vila Imagem, Simone Mina, Luciane Torres.

A Antônio Luiz Duran, Ana Bozeda, Ana Gold, Daniel Tapo, Daves Ottani, Erika Inforsato, Janaina Leite, Maria Tendlau, Marília Simões, Peri Pane, Peter Ribbon, Samira Brandão pelas leituras, conversas, auxílios e gentilezas durante a feitura deste trabalho. A Tarcila Lucena, pela revisão cuidadosa e competente.

A Lucia Camargo (in memoriam), Rodolfo Garcia Vásquez, Ivam Cabral, Joaquim Gama, Dione Leal, Elen Londero, Margarete de lara, Marie Iko, Djanira Batista, Heide Lins, Brenda Oliver, Kimberly Luciana, e toda a equipe da SP Escola de Teatro - Centro de Formação das Artes do Palco, que me acolheu e me ajudou a construir um percurso de pesquisa cênica.

A Mauricio Paroni pelas aprendizagens, amizade, e criações.

A Tom Vieira pela amizade dedicada, as criações conjuntas, por seus achados impossíveis e a sua inquietude contagiante.

A Sergio Zlotnic, um amor antigo que só aumenta. Por ter ajudado a dar corpo para a pesquisa e me dar palavras que abrem mundos, e pelas inspirações e frutos que esse encontro produz na arte e na vida.

A Monica Salgado, por tornar a existência mais possível.

A Thais Ruiz, Katia Bocci e Luiz Francisco de Carvalho Filho, que foram ótimos anfitriões, generosos e corajosos.

A Cayo Eduardo e Evelyn Eduardo, pela dedicação, amizade e criatividade no nosso percurso.

A Liliana e Nicholas Wahba, Claudia Niemeyer, Michele Ayed, Guilherme Zaramella, Fatima Monteiro, Fernanda Papaterra, Celso Leme, Wanderley Júnior, Elie Wahba, Ruth Bicudo, Cássia Navarro, e toda a equipe da Ser em Cena por me acolher e confiar em mim, e pela parceria frutífera nesse percurso que estamos trilhando juntos.

A Daina Leyton, Gregório Sanches, Leonardo Castilho, Laysa Elias, Mirella Estelles, Fátima Freire, Rogério Ratão, Karina Bacci, Laura Teixeira, Iraci Ferreira, Victor Danta, Amanda dos Santos, Bárbara Jimenez, Fernanda Zarvo, equipe e funcionários do Educativo do MAM. Agradeço pelas trocas, afetos e invenção de caminhos. Pelos aprendizados éticos e estéticos da convivência com vocês.

Em especial, as pessoas do Grupo de Pesquisa e Criação em Performance, aos participantes do curso de performance do Igual Diferente, ao elenco da ONG Ser em Cena, da cia. Ueinzz, e da cia. Zaum. Tantas pessoas e encontros. Agradeço por tudo o que me ensinaram, por terem confiado em mim e me acolhido, pelo nosso trajeto de invenções e pelos mundos que ainda vamos criar. 


\section{Resumo}

Esta dissertação descreve processos de criação cênica com coletivos heterogêneos, que podem ter entre seus integrantes pacientes psiquiátricos, pessoas com afasia ou com outras particularidades que as distanciam dos padrões hegemônicos de normalidade. Por meio do relato de experiências no meu trabalho como diretora, dramaturga e professora na Cia. Ueinzz, Cia. Zaum, ONG Ser em Cena, Grupo de Estudos e Criação em Performance e no curso de performance do programa Igual Diferente do Museu de Arte Moderna de São Paulo, o estudo investiga como as singularidades de diferentes modos de existência podem instaurar uma linguagem própria. Buscamos compreender como os materiais cênicos que criamos abrem possibilidades em relação à linguagem teatral, no sentido de rever, à luz desses coletivos, alguns aspectos do teatro contemporâneo e da performance, como a experimentação de diferentes temporalidades, a criação de outros de si e o deslocamento de uma ideia harmônica de beleza. Desse modo, a heterogeneidade acaba se constituindo como elemento de linguagem, de composição dramatúrgica e de encenação. Por fim, refletimos como essas práticas são estéticas e existenciais, e podem nos abrir a outras lógicas de criação e de vida. 



\begin{abstract}
This dissertation describes processes of scenic creative work with heterogeneous groups that may include amongst their members psychiatric patients, people with aphasia or other specific traits that distance them from hegemonic standards of normality. In reporting on my experience as director, playwriter and teacher at Cia. Ueinzz, Cia Zaum, NGO Ser em Cena, Grupo de Estudos e Criação em Performance, and at the Performance Course of the Program Igual Diferente of the Museum of Modern Art in São Paulo, I investigate in this study how singularities of different modes of existence may give rise to a new language. We seek to understand how do the scenic materials that we create, open possibilities of theatre language so as to review, in the light of these groups, some aspects of contemporary theatre and performance by experimenting different temporalities, the creation of another self and the shift of a harmonic concept of beauty. Thus, heterogeneity becomes an element of language, of dramaturgic composition and mise en scène. Finally, we reflect upon how those practices are aesthetic and existential and may open to us other logics of creativity and life.
\end{abstract}





\section{Lista de fotografias}

Fotografia 1 - Comendador Peçanha - Cia Zaum, 2005 ............................. 25

Fotografia 2 - Comendador Peçanha - Cia Zaum, 2005 ............................. 26

Fotografia 3 - Comendador Peçanha - Cia Zaum, 2005 ............................ 30

Fotografia 4 - Finnegans Ueinzz - Cia Ueinzz, 2009 ............................... 36

Fotografia 5 - Performance 3062014- Igual Diferente - MAM, 2014.............. 38

Fotografia 6 - Performance 7 bilhões e um - Grupo de estudos e criação em

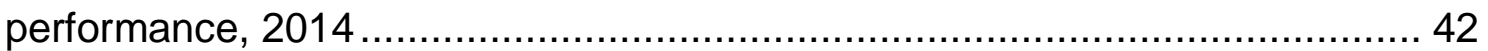

Fotografia 7 - Do outro lado do oceano - Ser em Cena, 2016 ...................... 44

Fotografia 8 - Curso de performance do lgual Diferente - MAM, 2018 .......... 53

Fotografia 9 - Curso de performance do Igual Diferente - MAM, 2018 .......... 62

Fotografia 10 - Silêncios, moléculas, dinossauros - Ser em Cena, 2018 ......... 64

Fotografia 11 - Perfomance Oito léguas para Fibo - Igual Diferente - Mostra

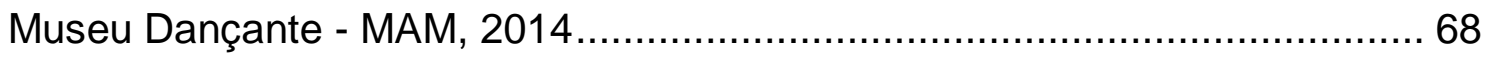

Fotografia 12 - Curso de performance do Igual Diferente - MAM, 2018 ......... 72 Fotografia 13 - Performace 7 bilhões e um - Grupo de estudos e criação em

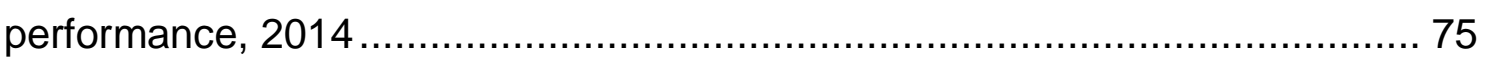

Fotografia 14 - Performance Oito léguas para Fibo - Igual Diferente - Mostra

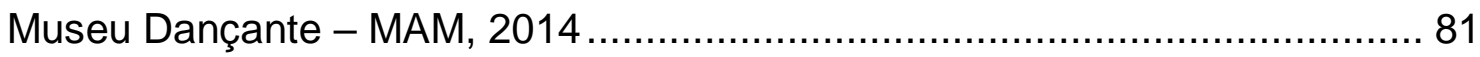

Fotografia 15 - Curso de performance do Igual Diferente - MAM, 2018 ......... 82

Fotografia 16 - Curso de performance do Igual Diferente - MAM, 2015 .......... 93

Fotografia 17- Performance 8 léguas para Fibo- Igual Diferente- Mam, 2014105 Fotografia 18 - Cena: A incrível orquestra de um homem só. Do outro lado do oceano - Ser em Cena, 2016

Fotografia 19 - Cena: A incrível orquestra de um homem só. Do outro lado do oceano - Ser em Cena, 2016 115

Fotografia 20 - Cena: O duplo. Silêncios, moléculas, dinossauros - Ser em Cena, 2019 119

Fotografia 21 - Comendador Peçanha - Cia Zaum, 2005 ............................ 128

Fotografia 22 - Curso de performance do Igual Diferente - MAM, 2018....... 131

Fotografia 23 - Cena: Desastre número um. Silêncios, moléculas, dinossauros - Ser em Cena, 2018. 133 
Fotografia 24 - Cena: Alfândega. Do outro lado do oceano - Ser em Cena, 2016

Fotografia 25 - Cena: Deriva. Finnegans Ueinzz - Cia Ueinzz, 2009............. 144

Fotografia 26 - Cena: Sala de espera do visto. Do outro lado do oceano - Ser

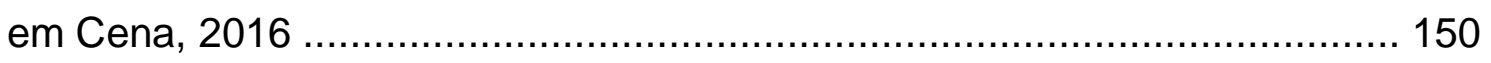

Fotografia 27 - Cena: Sala de espera do visto. Do outro lado do oceano - Ser

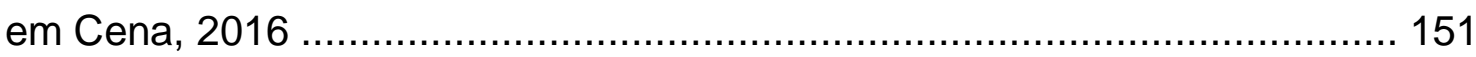

Fotografia 28 - Finnegans Ueinzz - Cia Ueinzz, 2009 .................................. 164

Fotografia 29 - Cena: Os marinheiros se lembram da terra. Do outro lado do oceano - Ser em Cena, 2016

Fotografia 30 - Cena: Comitê de observação das criaturas marinhas. Do outro lado do oceano - Ser em Cena, 2016 .................................................. 171

Fotografia 31 - Cena: Comitê de observação das criaturas marinhas. Do outro

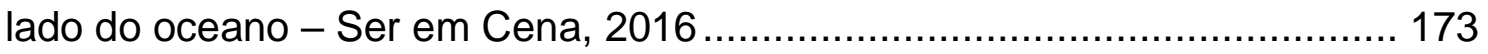

Fotografia 32 - Curso de performance do Igual Diferente - MAM, 2018 ........ 176

Fotografia 33 - Finnegans Ueinzz - Cia Ueinzz, 2009 ................................ 185

Fotografia 34 - Cena: O amor. Silêncios, moléculas, dinossauros - Ser em

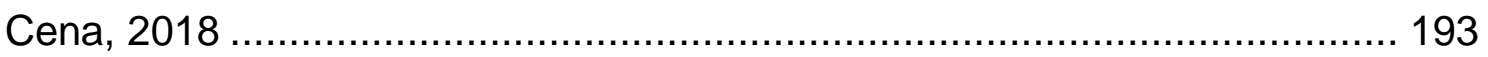

Fotografia 35 - Do outro lado do oceano - Ser em Cena, 2016 .................... 196

Fotografia 36 - Do outro lado do oceano - Ser em Cena, 2016 ..................... 198 


\section{SUMÁRIO}

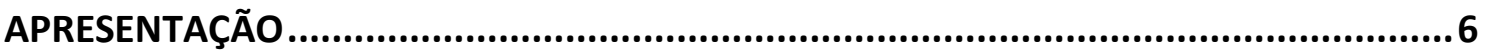

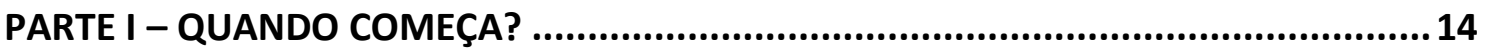

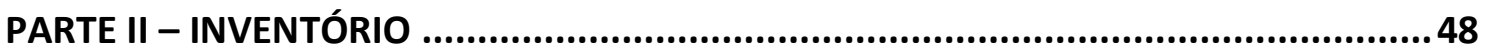

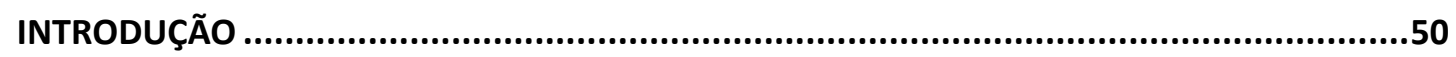

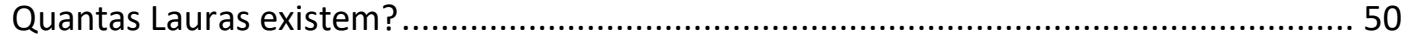

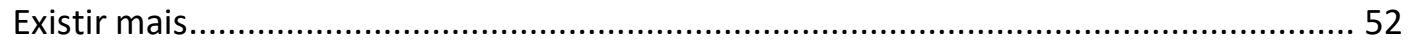

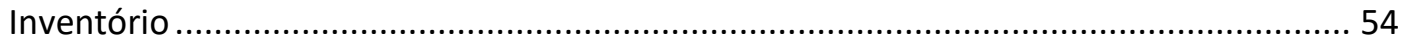

Improvisar saídas, programar o acaso ……................................................................. 55

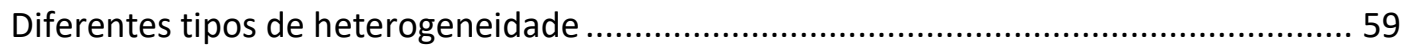

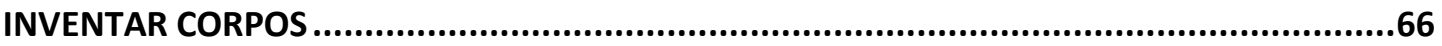

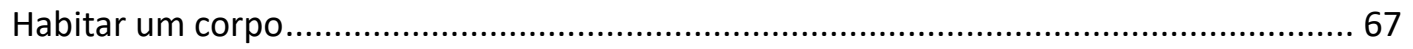

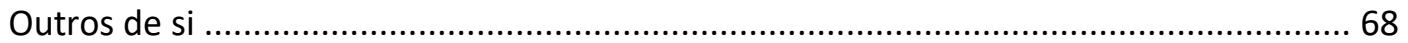

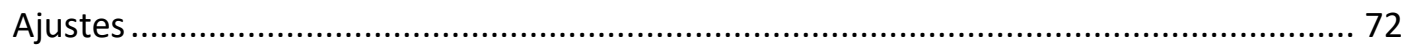

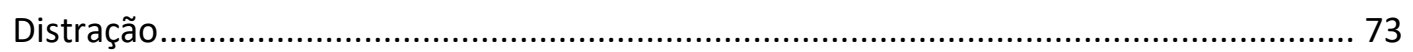

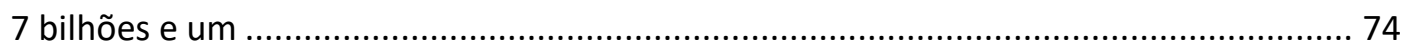

Então ele loucamente abriu a janela e viu o óbvio: seu corpo estava partido.................... 76

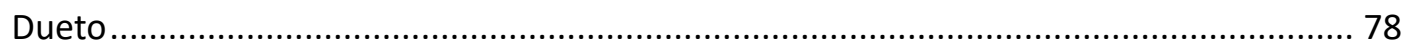

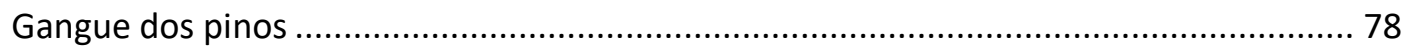

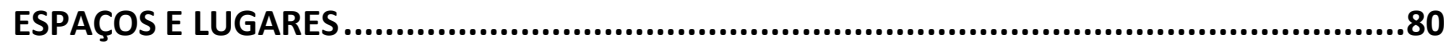

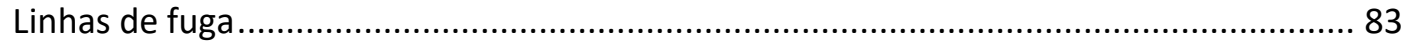

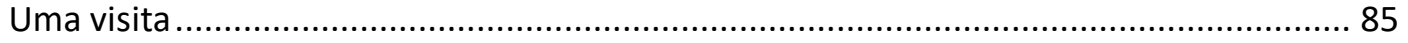

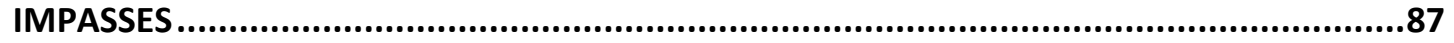

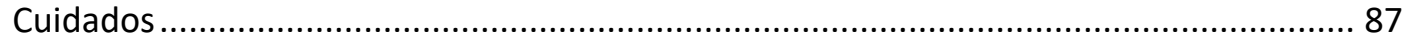

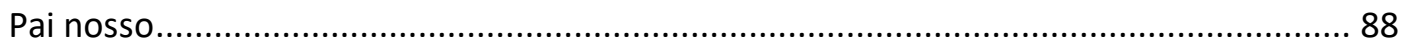

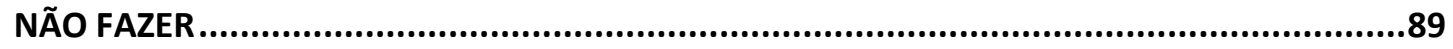

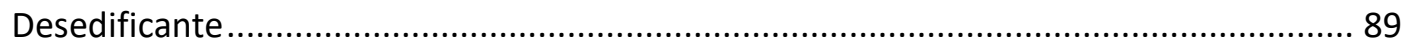

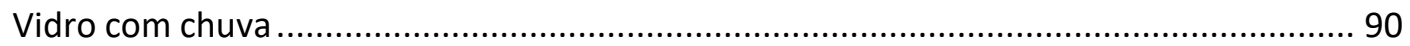

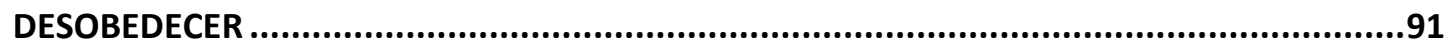

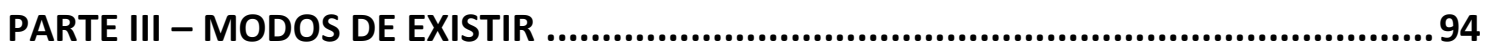

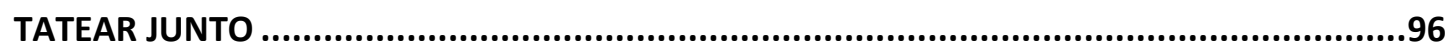

No dia 22 de abril de 2011 você me amava? ................................................................... 96

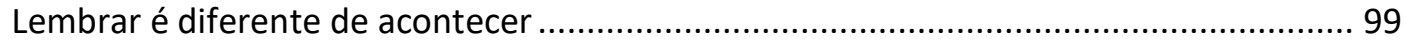




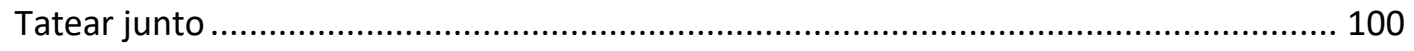

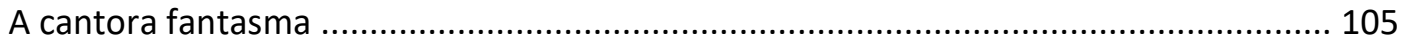

O roubo dos pertences da cantora fantasma ............................................................. 109

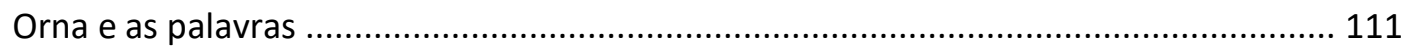

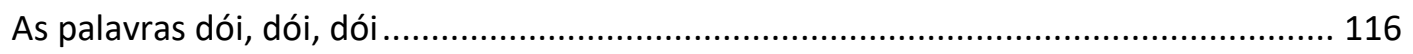

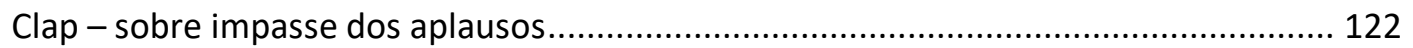

Reinvenções: produzindo outros Outros ................................................................... 124

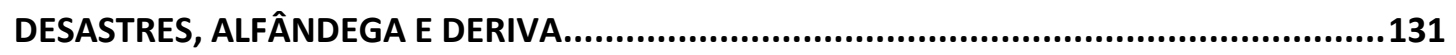

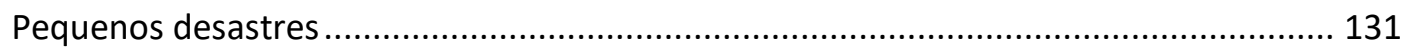

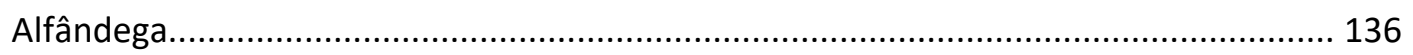

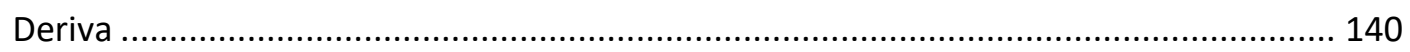

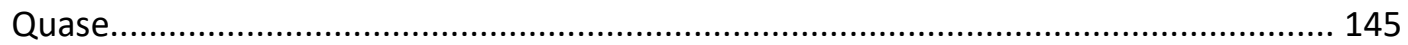

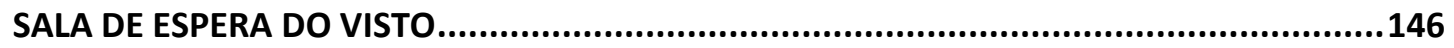

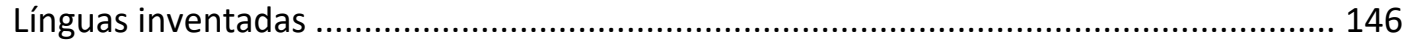

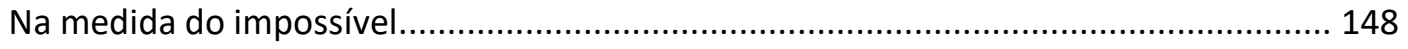

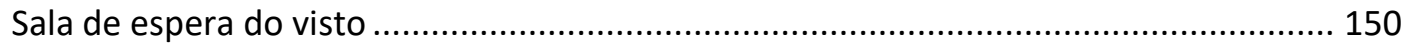

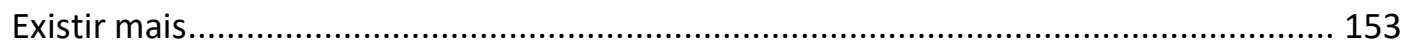

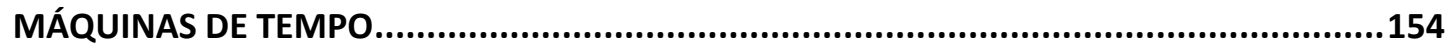

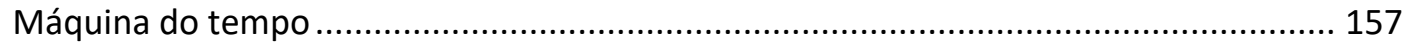

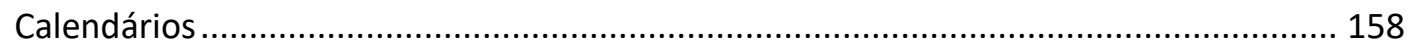

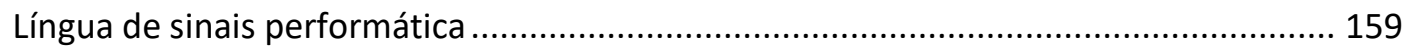

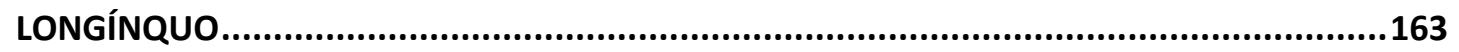

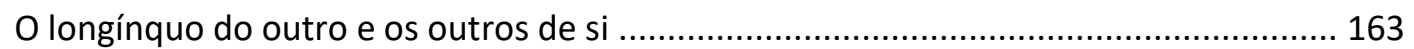

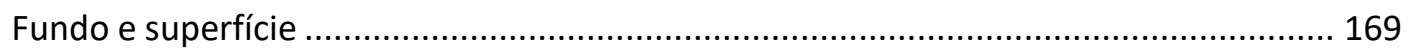

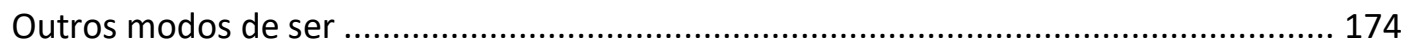

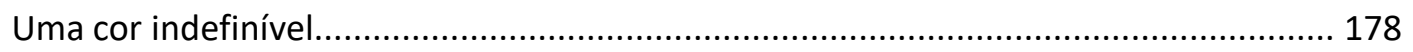

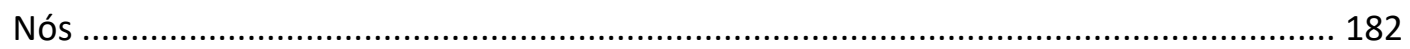

Encenação heterogênea ............................................................................................ 185

APÊNDICE - MÉTODO SEM MÉTODO .......................................................... 191

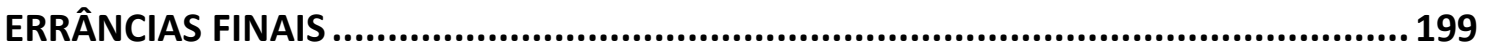

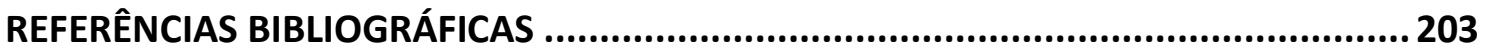


APRESENTAÇÃO 
Autonomia

Diante do perigo, a holotúria se divide em duas: deixando uma sua metade ser devorada pelo mundo, salvando-se com a outra metade.

Ela se bifurca subitamente em naufrágio e salvação, em resgate e promessa, no que foi e no que será.

No centro do seu corpo irrompe um precipício de duas bordas que se tornam estranhas uma à outra.

Sobre uma das bordas, a morte, sobre outra, a vida. Aqui o desespero, ali a coragem.

Se há balança, nenhum prato pesa mais que o outro. Se há justiça, ei-la aqui.

Morrer apenas o estritamente necessário, sem ultrapassar a medida. Renascer o tanto preciso a partir do resto que se preservou.

Nós também sabemos nos dividir, é verdade. Mas apenas em corpo e sussurros partidos. Em corpo e poesia. Aqui a garganta, do outro lado, o riso, leve, logo abafado.

Aqui o coração pesado, ali o Não Morrer Demais, três pequenas palavras que são as três plumas de um vôo.

O abismo não nos divide.

O abismo nos cerca.

(poema de Wislawa Szymborska) 
Os avós de uma amiga moravam em um lugar fronteiriço na região da Croácia. Com o passar do tempo, duas guerras, diferentes regimes e indexações, esse território mudou de nome, leis e línguas. Desse modo, o casal morou em cinco países diferentes sem sair do lugar. Finalizando a escrita da dissertação de mestrado, percebo o quanto me desloquei: escrever sobre a própria prática é também inventar mapas, línguas e nomes.

Há cinco cheiros que eu gosto: tomilho, hálito de gato, unha sendo lixada, qualquer coisa de lavanda (pode ser perfume ou desinfetante, a própria lavanda nunca cheirei) e madeireira. Gosto muito de listas. E de anotar os sonhos, que lembro todas as manhãs. Talvez pareça disparatado, mas listas, sonhos e disparates não só me apresentam, como estão intimamente conectados à essa pesquisa. Uma vez aprendi que o paradoxo não se resolve, convive-se com ele: preciso escrever, mas não gosto de quem fala que escrever é algo vital. Gosto do que escapa do grandioso ou do oficial, e vai em direção ao que é menor, que desencaixa. Gosto do que desvia, abre possibilidades, brechas, dentro do que parecia impossível, e faz a gente ganhar ares e territórios. Nas aulas de educação física no colégio, havia o costume de duas pessoas escolherem os times. Não sei como se escolhiam essas duas pessoas, mas eram sempre as mesmas. Uma de cada vez, falavam o nome das outras. Uma de cada vez. Entre cada nome, um silêncio. Que. Durava. Muito. Tempo. Havia uma alegria crescente em quem era logo chamada, e um desconforto em quem ia ficando. No final sobrávamos nós, sempre, eu e mais alguém. Tínhamos que desenvolver um jeito de estar ali do melhor modo possível. As meninas que escolhiam, meninas que não erravam o passo nem a coreografia nem 0 gol nem $0 x$ da questão, passeavam 0 olhar sobre nós para ver quem seria a próxima. Isso poderia demorar minutos. Horas. Dias. Elas decidiriam quem ia sobrar, as dos movimentos certos. A gente quase se acostumava. Aos poucos, desenvolvíamos estratégias: sussurrávamos "me chama!", quase chorávamos, nos revoltávamos, fingíamos indiferença, ou olhávamos para outro lugar. Esses momentos na quadra contribuíram na invenção de outros modos de criar junto e de se organizar coletivamente, menos ligados à ideia de eficácia, produtividade ou ideal. 
II.

Participei de alguns processos de criação com coletivos formados por pessoas das mais diversas idades, corpos, formações e bagagens de vida. Algumas tinham passado por experiências com loucura, ou tinham outros tipos de particularidades que as colocavam distantes de uma ideia comum de "normalidade", ou de um treinamento técnico nas artes cênicas.

Comecei a perceber como essas experiências produziam uma beleza de caráter extraordinário e que se dava nas descobertas do dia a dia, feita de fragilidades e assimetrias. Ali encontrei uma potência diferente da maioria das criações que já havia visto ou participado no teatro, e isso acontecia pela multiplicidade dos modos de existências presentes nesses coletivos.

O campo comum era de criação artística, principalmente cênica, mas a potência e a originalidade desses processos eram também feitas de instâncias afetivas, coletivas, políticas, clínicas e sociais. Fui percebendo que não somente essas pessoas podiam fazer teatro, mas que também elas esgarçavam e faziam repensar algumas ideias do teatro e da performance, que poderiam ganhar uma nova vitalidade com esse tipo de criação.

III.

Fui aos poucos pensando em juntar as ideias que estavam me habitando, pensamentos sobre as práticas de criação artística que venho desenvolvendo com coletivos variados. Em algum momento, tive um fôlego um pouco maior para dar o próximo passo. Esse fôlego tem a ver com querer compartilhar algumas perguntas, vulnerabilidades, descobertas e aprendizados.

Um parágrafo por vez. Eu me assusto com tamanhos, preciso olhar onde estou e tomar fôlego para o próximo passo. Às vezes retrocedo, desconfio, duvido. Depois volto a respirar e a experimentar os meus passos: a escrita dentro desse ambiente. A escrita também experimenta um jeito de viver.

E por isso ela é corporal, intensa e cansa, embaralhando teoria e prática que não são avessos, mas fluxos. Ao escrever sobre, revivo esses processos, vendo-os de outro jeito, o que os transforma, e também me transforma. Conseguir distância para observar eventos que foram vividos tão de perto e tão intensamente me fez estranhar meu próprio percurso. No espanto de ver as 
mesmas coisas de um outro jeito, o processo desta pesquisa e de sua escrita de alguma forma ampliou meus territórios existenciais de um modo que, às vezes, pode parecer mínimo, no entanto, foram movidas profundidades e placas tectônicas para que certas palavras e frases pudessem aparecer.

IV.

Ah. E escrevo no meio do desastre. O que é ruim: ao mesmo tempo que escrevo, tenho que dar um jeito de viver, e com a perspectiva de que sempre pode ficar pior. A quarentena que dura seis meses, a visão diária de um país desgovernado que mata as pessoas de quem deveria cuidar, a indeterminação em sua proximidade com a morte e com a invenção de outros tipos de cotidiano. Mas escrever torna um pouco melhor atravessar esses dias. Descrevo aglomerações, trios que se misturam com outros trios transformando a dança, pessoas que se juntam formando um montinho humano em que é possível sentir a respiração da pessoa que está ao lado, e nesses momentos me sinto uma paleontóloga descrevendo mundos antigos. As pistas que posso dar, iluminando possibilidades para outras pessoas e grupos em suas criações, ficam com um cheiro de arqueologia. Continuo mesmo assim. Alguma hora surge a cura e as coisas voltam, mas voltam para onde? Esta dissertação e os processos nela analisados são justamente para questionar uma ideia de normalidade e imaginar outras possibilidades: de existência, de estética, de micropolíticas, pois as que estão aí, mesmo desde antes, bem antes, não dão conta.

Descrevo essas experiências sem querer ser farol nem fóssil, e acredito que, mesmo de dentro da catástrofe, podemos inventar outras modalidades de corpos, de relação com o corpo, de estéticas, de éticas coletivas, de jeitos de produzir diferenças que abram caminhos, ou pelo menos trilhas, ou brechas, frestas, pontos de fuga, linhas de fuga, pontos de apoio, balsas, jangadas, linhas de errância, derivas, saídas de emergência, válvulas de escape, pequenas iniciativas, devires moleculares, dancinhas mínimas, línguas inventadas, silêncios, esperas, hesitações, e possamos, mesmo no meio do desastre, inventar mundos possíveis dentro deste. 
V.

Esta dissertação procura investigar como as práticas que temos desenvolvido ao longo dos anos com coletivos heterogêneos instauram uma linguagem cênica. Todas essas experiências de alguma maneira foram nos dando pistas de diferentes modos de organização coletiva e criação artística, assim como da invenção de narrativas que têm a ver com legitimar o assimétrico, o dissonante, o estranho, e transformar isso em linguagem, criar sentidos.

Além disso, essas experiências podem ser maneiras de desfazer, ou de oferecer alternativas, às estratégias e práticas de silenciamento, exclusão e invisibilidade de alguns variados modos de existência. Ao longo dos anos, sem querer, fui me especializando em uma grande gama de diferenças, experimentando diversos tipos de heterogeneidade. Fui aprendendo como essas diversidades experimentam para si mesmas e também lançam no mundo outros tipos de circulação de valores e de afetos. Sem metodologia ou projeto de ancoragem nesta trajetória, fui experimentando, na prática, a cada coletivo e a cada encontro, modos de funcionamento e de desfuncionamento, possibilidades e impasses, fracassos que levavam a criação de novas possibilidades ou fracassos que eram simplesmente fracassos.

VI.

Este trabalho descreve processos de criação: de linguagem, de histórias, de mundos, de possibilidades. Investigar esses percursos relembra que a criação estética é atravessada e atravessa vários outros campos e direções: afetivos, políticos, sociais. E analisar os processos criativos levando em consideração essas diferentes instâncias pode nos ajudar a inventar outros jeitos de criar e de viver.

No primeiro capítulo, descrevo o meu percurso com os coletivos analisados para que se possa contextualizar as experiências analisadas posteriormente. Essa descrição traz momentos inaugurais das experiências relatadas. Além dos relatos, a ideia de começo é questionada.

No segundo capítulo, são investigados os processos cênicos no seu dia a dia. O que acontece na sala de ensaio, como os materiais criativos surgem e 
que tipos de diapasões estético-existenciais coletivos são instaurados em cada grupo. Também são descritos como alguns procedimentos e dispositivos de criação engendram diversas possibilidades de se pensar corpo, improvisação e heterogeneidade, além das inquietudes e descobertas desses cotidianos.

No terceiro capitulo, também são analisados os encontros e a criação de materiais cênicos, mas aqui com ênfase na resultante: na elaboração de uma dramaturgia cênica e na composição do material criativo em uma encenação, ou filme. Investigamos como a organização desses materiais abrem possibilidades de se rever alguns aspectos do teatro contemporâneo à luz dos coletivos heterogêneos: a criação de outros de si, a invenção de línguas, o deslocamento de uma ideia harmônica de belo e a distensão do tempo.

Após os capítulos, compartilho um encarte chamado método sem método. É uma espécie de glossário, no qual reuni alguns procedimentos e dispositivos de criação que foram experimentados na elaboração e criação de espetáculos e performances, em uma junção de estética, clínica e pedagogia. 
PARTE I - QUANDO COMEÇA? 
No dia 22 de abril de 2012 você me amava?

(Pergunta feita por Olivia Leirner durante os encontros do curso de performance no MAM) 
Uma velha com cabelos compridos, grisalhos e bagunçados morava em casa. Era quase possível ver a camisola amarfanhada com que ela voava dentro das paredes e bagunçava toda a fiação. Eu sabia disso porque ouvia minha mãe e a tia Lucy conversando sobre a Aláit, que cortava a luz das casas de uma hora para a outra. Uma noite ouvi os primeiros acordes, deitada no escuro (o escuro era domínio da velha). Chovia, e de dentro do barulho da chuva, vieram as primeiras notas. Com o coração explodindo corri para a cama da minha mãe e tentei explicar que a Aláit tocando piano não me deixava dormir.

Recém-formada em teatro, trabalhei como recepcionista em congressos médicos, garota propaganda, caçadora de morcegos (acompanhei como tradutora uma expedição pelo interior de São Paulo com nove veterinários para testar uma armadilha que pegava somente morcegos raivosos) e quase fui sereia dentro de um aquário em uma festa de lançamento de uma campanha de desodorantes. Em algum momento dessa época (final dos anos 1990), pelo telefone, um homem me explicava sobre a entrevista de emprego que eu teria no dia seguinte em seu escritório. Contou que sua empresa ficava em Pinheiros e perguntou onde eu estava. Achei um pouco estranha a pergunta, mas respondi: na cozinha. Ele explicou que estava perguntando em que região de São Paulo eu morava.

Helsinque. Finlândia, 2009, viagem da Cia. Ueinzz para apresentação do espetáculo Finnegans Ueinzz. Caos no dormitório em que parte do elenco está hospedado. Alexandre, um dos atores mais antigos da companhia, precisa atender uma urgência, coloca uma muda de roupas na minha mão e pede para eu dar uma força para Guilherme com o banho. Ajudo Guilherme a tirar a roupa, levo-o para o chuveiro, começo pelo cabelo, depois passo o sabão nas costas. Quando termino as costas e os braços, vou para o peito, desço para a barriga e pergunto, meio sem graça, como ele costuma fazer. Guilherme fala que geralmente toma banho sozinho. Saio de lá e espero ele terminar para ajudá-lo a se vestir.

Oficina de teatro ministrada pelo ator e diretor Cacá Carvalho a partir do livro $A$ peste, de Albert Camus, no Sesc Campinas, 1996. Foi uma oficina de quatro horas diárias, por duas semanas. O resultado cênico foi convidado a ficar dois meses em cartaz no Sesc. Minha primeira experiência bem-sucedida 
com o realismo. Anos depois, alguém me conta que trabalhou com Cacá e ele falou sobre mim: "a Elisa é uma pessoa que faz tudo errado, e por isso faz tudo certo".

Algum momento de 2018. Marco com um colega um encontro. Chego no local, uma rua em declive, e ligo para ele, que atende, fala que já está lá e pede para eu olhar para baixo. Olho, um pouco constrangida, para baixo de uma van estacionada na calçada, imaginando-o deitado embaixo do carro, ou em um alçapão que eu posso não ter percebido, quando ele fala para eu olhar para minha direita, mais embaixo na rua, eu finalmente o vejo mais adiante, rindo muito, rio também.

Aniversário de oito anos próximo. Minha mãe me chamou para o nosso ritual de comprar os enfeites da festa. Falei que não precisava. Ela estranhou e quis saber por quê. Desconversei. A festa antes da festa era ir na papelaria do seu Luís comprar papel crepom, purpurina, bexiga e outras bugigangas que fossem coloridas, fizessem barulho ou brilhassem. Ela insistiu. Expliquei que, se eu não fizesse festa de aniversário, não iria ficar mais velha e assim não precisaria morrer.

Quando é que alguma coisa começa? Esses são modos de imaginar inícios. São momentos em que houve um desencaixe, um lapso, outro modo de ver. Em alguns casos, esse lapso produziu, de alguma maneira, um gesto criativo. (Em outros foi apenas um desastre mesmo.) Um não saber fazer que inventa coordenadas.

O percurso que relato a seguir está conectado a esses momentos, não somente como um desdobramento cronológico, mas cartográfico, no qual tempos e espaços diferentes, coletivos e individuais, são convocados na experimentação de uma cartografia que tenta inventar outros possíveis.

Para os geógrafos, a cartografia - diferentemente do mapa: representação de um todo estático - é um desenho que acompanha e se faz ao mesmo tempo que os movimentos de transformação da paisagem. Paisagens psicossociais também são cartografáveis. A cartografia, nesse caso, acompanha e se faz ao mesmo tempo que o desmanchamento de certos mundos - sua perda de sentido - e a formação de outros mundos $[\ldots]^{1}$.

\footnotetext{
${ }^{1}$ ROLNIK, Suely. Cartografia sentimental. Porto Alegre: Editora da UFRGS, 2011. p.23.
} 
O sentido cartográfico trazido por Suely Rolnik nos lembra que a reinvenção acontece também em direção ao passado. A memória é retroativa, e assim como um fato do passado pode lançar luz sobre um acontecimento presente, um acontecimento presente também pode ressignificar o passado, de modo que a reinvenção de mundos, para acontecer, precisa se dar em diferentes direções de tempo e espaço.

Dentro dessa reinvenção topográfica-existencial, vou trazer mais alguns começos. São momentos inaugurais de práticas com coletivos heterogêneos, mais explicitamente ligadas a esta dissertação, mas ainda entrelaçadas a outras, menos explícitas, mas que também ancoram as experiências.

Em 1993, um amigo americano vendeu todas as suas coisas, pediu demissão, comprou um carro velho para ir dirigindo até o Alasca, em uma viagem que duraria meses. Ele me convidou para ir junto; quase fui, mas acabei decidindo por ficar no Brasil e prestar vestibular para artes cênicas na Unicamp.

Em 1998, eu estava no último ano de graduação. Naquela época, cada ano uma pessoa externa ao quadro docente era convidada para dirigir a montagem final. A turma sugeriu vários nomes, ao final ficou dividida e tínhamos que escolher entre Renato Cohen e outro diretor. Lembrei-me de um espetáculo que havia visto algum tempo antes, em um casarão na Vila Mariana, a Casa Modernista. A cena acontecia à noite e era inspirada no movimento romântico alemão conhecido como Sturm und Drang, que ocorreu de 1760 a 1780. Os atores/performers imantavam os espaços e nichos diferentes do casarão com suas estranhas figuras, e de tudo, o que ficou na minha memória é a sensação de ter sido imersa em outra atmosfera imantada de presenças que não me contavam exatamente nenhuma história, mas compartilhavam comigo outra intensidade e outra possibilidade de criação, na qual as coisas pareciam se dar sem o aparato de enredos, mas diretamente se conectavam com zonas de sombra, de delírios, devaneios e encantamento. Votei no nome do Renato.

Formamo-nos na Unicamp em Artes Cênicas em 1998 com a performance $\mathrm{Ka}$ - Cena Zaum, dirigida por Renato Cohen. A performance foi criada a partir do livro Ka, de Velimir Khlébnikov, um autor russo, mestre e inspirador de poetas como Maiakovski. Esse livro curto e enigmático, de 
linguagem misteriosa e poética, era inspirado na mitologia egípcia. Um dos aprendizados dessa experiência foi o de perceber como uma obra aberta, cifrada e caleidoscópica pode ser fértil a um processo de criação no qual o texto é mais um disparador entre os vários elementos da gramática cênica. Essa experiência com Renato Cohen foi um alicerce de caminhos posteriores, e a turma que se formou deu início ao grupo $\mathrm{Ka}^{2}$. Renato foi um dos pioneiros e um dos principais expoentes da performance no Brasil ${ }^{3}$.

Ancoradas por ele, nossas práticas incorporavam procedimentos, estímulos e referências das mais variadas linguagens, como dança butoh, alteração da consciência através da respiração, vivências xamânicas, criação de personas, estudo de mitologias egípcias e do campo mítico como um dos suportes da atuação, danças rituais, diferentes equilíbrios e estados corporaismentais-vibracionais, além de outras operações e vivências fora do contexto da representação e das artes cênicas, trabalhos que envolviam situações-limite físicas e psíquicas. Renato se utilizava livremente desses procedimentos e estímulos, de modo às vezes iconoclasta, e o que contava era muito mais a intensidade de nossas experiências, os acontecimentos do encontro, do que a aquisição de algum treinamento ou técnica específicas - não que elas não fossem importantes, mas aconteciam mais no sentido de proporcionar uma experiência do que oferecer ferramentas para uma virtuose. Pudemos experimentar, com ele, na teoria e na prática, a criação de uma cena hipertextual. Ao investigar a atuação nos processos de criação, Renato descreve essa multiplicidade de camadas:

Operamos num campo de fronteira, campo "para", topos de manifestações e experimentos limites, híbridos - performances, happenings, rituais étnicos, teatro de fontes, teatro de imagens-, linguagens estas que trafegam por particularidades temáticas, de representação e apresentação (temas autobiográficos, ambiguidade entre o espaço real e o ficcional, narrativas disjuntivas, uso do work in process como tessitura $)^{4}$.

\footnotetext{
${ }^{2}$ Dirigido por Renato Cohen e, nesse primeiro momento, composto por mim, Fábio Fonseca de Melo, Fábio Santana, João André da Rocha, Gustavo Arantes, Marcial Asevedo, Rachel Brumana, Samira S. B. Borovik, Rennata Airoldi e Rita Wirtti, Cássio Santiago, Marina Reis.

${ }^{3}$ Renato Cohen faz um estudo importante da linguagem da performance no Brasil em seus livros: COHEN, Renato. Performance como linguagem. São Paulo: Edusp/Perspectiva, 1989; e Work in progress na cena contemporânea. São Paulo: Perspectiva, 1998.

${ }^{4}$ COHEN, 1998, p.60.
} 
Renato tinha uma busca constante pela epifania da cena, um acontecimento estético e existencial que fosse transformador, seja para a equipe de criação, seja para o público. Para isso, "todas as vivências propostas por Cohen aproximavam nossa vida pessoal do fazer artístico, numa retroalimentação constante". ${ }^{5}$

Após $K A$, criamos a performance Doutor Faustus liga a luz, experimentando o minimalismo de Gertrude Stein e somando a esse universo rituais judaicos e cabalísticos e figuras de Tarô.

Renato convidava pessoas de diversas áreas e linguagens para participar de seus processos: no Ka, juntaram-se a nós o artista plástico, cenógrafo e arquiteto Arnaldo de Melo, seu colaborador de outros espetáculos, que produziu as instalações, mapas cartográficos e desenhos das cenas, assim como Marina Reis, que durante todo o processo trouxe propostas de body art e figurinos, e Lynn Mário Menezes de Souza, professor da Faculdade de Letras da USP que nos iniciou ao mundo do xamanismo por meio de vivências e transes conscientes nos quais "os encontros com o xamã se caracterizaram como laboratórios/retiros de criação [...]"6. "O performer, através de laboratórios, visões, toma contato com alteridades (um outro), com seu devir animal (animal de poder), [desenvolvendo uma] capacidade de ser 'outrado', para usar uma expressão deleuziana, de revelar e atuar, multiplicidades de seu ser."

As propostas de alguns desses artistas (como Arnaldo, Lynn Mário e Marina) não vinham para se acoplar a algo que já existia, mas eram criadas a partir da convivência durante todo o processo, e também eram disparadoras de muitas das cenas. Além desses dois colaboradores, também fizemos workshops de voz e conexão com Madalena Bernardes, de dança contemporânea com Holly Cravell e Lara Pinheiro, assim como palestras sobre as vanguardas russas com a pesquisadora Aurora Bernardini e o performer Lucio Agra.

\footnotetext{
${ }^{5}$ BOROVIK, Samira S. B. KA: a sombra da alma: performance e xamanismo no espetáculo de Renato Cohen. São Paulo: Annablume, 2014. p.84. Para um conhecimento mais aprofundado desse processo, sugiro esse livro, que é a dissertação de Samira S. B. Borovik, e faz uma investigação da criação desse espetáculo.

${ }^{6}$ Ibidem, p.59.

${ }^{7}$ COHEN apud BOROVIK, 2014, p. 71.
} 
No segundo trabalho, Doutor Faustus liga a luz, tivemos a participação de Fabio Fonseca de Mello, que também havia colaborado no KA e aqui traduziu o texto de Getrude Stein, e do artista plástico Pedro Lopes, que trouxe uma proposta de cenografia a partir de elementos da cabala e dos rituais judaicos. Em ambos os trabalhos, vivenciamos uma abordagem mais horizontal de criação: "Renato nos mostrou a importância da autoria, da cocriação das cenas através do envolvimento de todos os artistas [...]. Essa é uma postura de não oposição entre o trabalho do ator e da equipe em geral" ${ }^{8}$.

Foram experiências que trouxeram conhecimentos que continuam até hoje reverberando: autoria do artista, coletivo interdisciplinar, escritura cênica feita dos mais diversos elementos, liberdade de se criar a coerência própria de uma obra a partir da multiplicidade etc.

Esse momento é importante no relevo de nossa cartografia, pois permitiu um olhar aberto e curioso sobre o que é a arte e quem pode ser artista, além de experimentarmos na prática a interdisciplinaridade da performance e suas vivências e dispositivos de criação que borram as fronteiras de arte e vida:

A busca de desenvolvimento pessoal é um dos princípios centrais de performance e da live art. Não se encara a atuação como uma profissão, mas como um palco de experiência ou de tomada de consciência para utilização na vida. Nele não vai existir uma separação rígida entre arte e vida ${ }^{9}$.

A partir daí, cada vez mais fui diminuindo os trabalhos em outras áreas, mas ainda me abrindo a experiências como acompanhar médicos em um barco para ver crocodilos na Amazônia, dentro de um congresso médico realizado em um hotel no meio da selva (eu era assistente da coordenadora do evento). E fui me fixando nas artes, mas ainda dentro de uma heterogeneidade de áreas e de experiências. Participei de espetáculos e performances como atriz, performer, diretora e dramaturga. Toquei baixo na banda de rock Anthony Perkins Cover (antes fiz aulas de piano quando criança; antes cantava sozinha no quarto, quando começa?). Fiz cursos e workshops de dança com Andreia Yonashiro, Cristiane Paoli Quito, Yoshito Ohno, Zelia Monteiro etc. (Antes, nas aulas de dança, eu era a que ficava atrás e virava para um lado diferente de todo

\footnotetext{
${ }^{8}$ BOROVIK, 2014, p. 123.

${ }^{9}$ COHEN, 1989, p.105
} 
mundo, talvez isso tenha influenciado eu poder inventar coreografias que não tenham lado errado; antes, fazia coreografias em dupla com meu primo, apresentávamos no quintal para mãe, irmão, plantas, gato, cachorro, sempre com muito sucesso, ainda não errávamos o lado).

Em 2015, ganhei um concurso para autores estreantes e publiquei o livro de contos Perecíveis, pela editora Lamparina Luminosa (antes, escrevi a vida toda em muitos cadernos). Alguns dos contos originaram performances, ou surgiram de trabalhos cênicos. O livro é um entrelaçamento, escritas híbridas entre cena, literatura e vida. Em um dos contos, explico como gostava de dar aulas imaginárias, que aconteciam na lavanderia. Um dos principais temas eram as partes do corpo (que até hoje são um dispositivo de criação nos encontros de todos os coletivos que participo). Apesar desse procedimento ter aparentemente surgido de exercícios com Cristiane Paoli Quito, ao escrever esta descrição do percurso percebo esse outro antes.

Sempre participei de atividades pedagógicas (as aulas na lavanderia contam?), e a partir de 2003 juntei a esse percurso, no início de modo acidental, as experiências com coletivos heterogêneos, com pessoas dos mais variados corpos, formações e experiências de vida: de 2003 a 2005, fui uma das diretoras da Cia. Zaum, que tinha como integrantes artistas convidados e o público do Centro de Atenção Integrada em Saúde Mental Dr. David Capistrano da Costa Filho - CAISM da Água Funda ${ }^{10}$. A companhia surgiu de uma oficina ministrada por Cássio Santiago com os pacientes. Ao final da oficina, o grupo continuou a se encontrar por um tempo, e em determinado momento Cássio propôs que, junto com Arnaldo Melo, artista plástico, Cristine Peron, atriz e psicóloga, e eu, nos juntássemos como um núcleo de direção do coletivo que estava surgindo"1. O termo "Zaum" veio de Velimir Khlébnikov, autor de Ka: era uma linguagem transmental idealizada pelo poeta, de caráter encantatório e anterior a significados, ou "além dos limites da razão"12, composta de

\footnotetext{
${ }^{10}$ CAISM é uma unidade da Secretaria de Estado da Saúde especializada em psiquiatria e que presta assistência médico-hospitalar em saúde mental, em regime de internação integral em hospital-dia e em ambulatório, assim como oferece recursos de lares abrigados. Disponível em: <http://www.cidadao.sp.gov.br/servico.php?serv=303292>. Acesso em: 8 jun. 2019.

${ }_{11}$ Cássio na direção, Cristine Peron e eu como codiretoras, e Arnaldo como diretor de arte.

${ }^{12}$ BOROVIK, 2014, p.52.
} 
"palavras-olhos, com as quais é possível ver, e palavras-mãos, com as quais é possivel fazer" ${ }^{13}$.

Esse é um possível começo da busca de um modo próprio de lidar com as diferenças. Ou talvez, sem eu saber, tenha começado bem antes. Quando crianças, eu e meu irmão mais velho tínhamos uma brincadeira: eu colocava os pés dele sobre os meus, segurava nas suas mãos e "andávamos" juntos desse modo. Às vezes dava até para dançar um pouco. Ele se matava de rir e eu também, mas eu tinha que ficar mais concentrada senão podíamos cair, o que chegou a acontecer uma vez ou outra.

Ele tem paralisia cerebral, anda de cadeira de rodas e tem alguns de seus movimentos dos braços comprometidos (a chamada motricidade fina, responsável por movimentos delicados como pegar uma folha de papel ou escrever). $O$ fato de eu ter um irmão com essa particularidade não garante que saiba lidar com as diferenças, mas nossa mãe fez o possível para criar um lugar em que essa diferença não caísse nas duas armadilhas mais comuns: de vê-lo como coitadinho (ver a pessoa pelo que falta nela - e essa falta só existe na comparação) ou como exemplo de superação (ou de achar que alguém é um exemplo de vida só por existir). Acredito que ela conseguiu, e grande parte dessa trajetória tem a ver com aqueles momentos de descobrir esse jeito de dançar junto, por exemplo.

Voltando à Companhia Zaum, junto a esse coletivo encenamos o espetáculo Comendador Peçanha, de Marcos (O) Sanchiú, usuário do CAISM que escreveu o texto e criou os personagens para os outros pacientes que ele já conhecia. Diferente de todos os outros trabalhos analisados nesta dissertação, esse espetáculo nasceu a partir de um texto pronto, mas que teve mudanças dramatúrgicas durante o processo de encenação. Tratava-se de uma história de intrigas políticas e amorosas, com toques de espionagem e complôs dos mais diversos, tema caro ao autor, que era muito interessado em temas como CIA, KGB, ninjas e demais organizações de artes marciais e espionagem, e encontrava, na escrita desses textos dramatúrgicos, um canal

\footnotetext{
${ }^{13}$ KHLÉBNIKOV, Velimir. KA. Tradução e notas de Aurora Fornoni Bernardini. São Paulo: Perspectiva, 1977. p.14.
} 
de escoamento dos atravessamentos que o povoavam, como ele mesmo falava nos ensaios. De acordo com o texto do programa:

A Companhia Zaum apresenta a performance ", a partir do texto original de Marcos (ô) Sanchiú (2001) e da elaboração processual deste ano. Comendador Peçanha descreve um dia particular no Palácio do Governo. Dois Comendadores próximos do Gabinete, onde está também a residência do Governador, com sua filha e primeira-dama, disputam espaço com o cerimonial e os despachos. As surpresas no interior do palácio extrapolam a política e se desdobram em grandes casos amorosos, maracutaias, relaccões de poder e conflitos entre a medicina e ciências do além ${ }^{14}$.

Ensaiávamos no hospital-dia e, em um determinado momento, conseguimos um espaço de ensaio e apresentações na Biblioteca Mário de Andrade: o deslocamento do espaço de criação de um hospital psiquiátrico para um espaço cultural no centro da cidade promoveu deslocamentos físicos, simbólicos e existenciais. Nessa época, Marcos nos relatou que, antes, tinha muito medo de andar pela cidade. Então decidiu dar um "truque nele mesmo" (como ele contou), e fingir que não tinha medo. Assim conseguiu participar do processo, conviver melhor com seu medo e ter uma maior mobilidade. Depois dos encontros semanais com o grupo, nós quatro (eu, Arnaldo, Cássio e Cris) íamos para a casa de Arnaldo, que ficava bem na frente da Biblioteca. Essas reuniões, que avançavam noite adentro, eram uma continuação do encontro e um espaço de metabolização dos ensaios, troca de experiências e aprofundamento da proposta da encenação. Arnaldo (assim como fez no processo com Renato) fazia desenhos que traduziam e materializavam as nossas conversas, as ideias de cenário e figurino, assim como ampliavam as referências imagéticas do universo de cada personagem. Depois compartilhávamos com o grupo essas ideias e desenhos, que tinham um efeito forte ao mostrar possibilidades da cena em forma de imagens.

À medida que o roteiro foi se delineando, convidamos várias pessoas para participar do espetáculo: atores, performers, músicos e pessoas de outras áreas, de modo que tínhamos quase trinta pessoas em cena. Para a entrada dessas pessoas, fizemos algumas mudanças dramatúrgicas. Por exemplo, inventamos uma situação de personagens que iam ter audiências com 0

\footnotetext{
${ }^{14}$ Programa do espetáculo Comendador Peçanha.
} 
governador, o que permitiu encaixar a entrada de mais gente dentro da dramaturgia proposta pelo autor.

Fotografia 1 - Comendador Peçanha - Cia Zaum, 2005

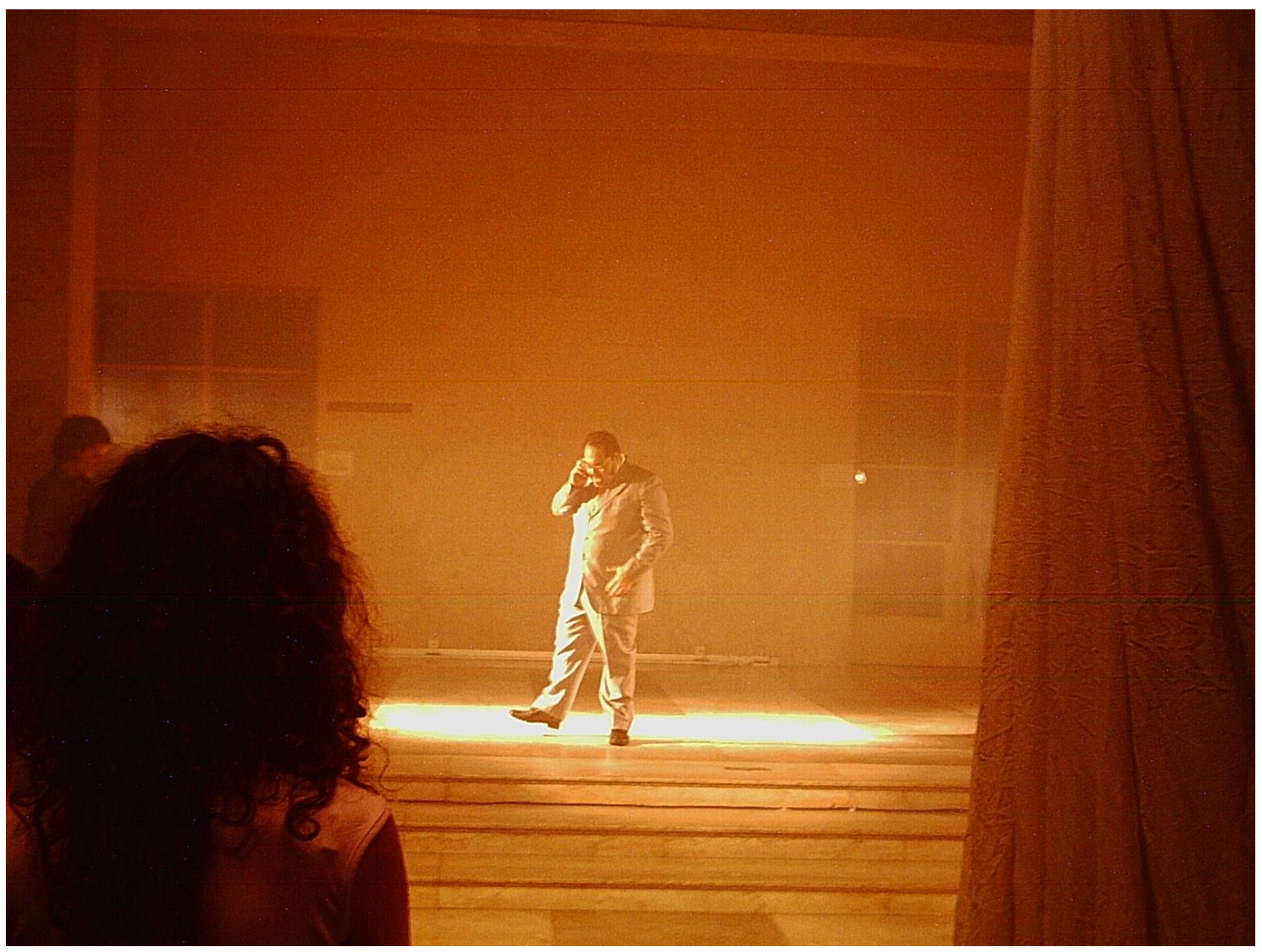

Marcos (Ô) Sanchiú. Foto: acervo pessoal.

A peça acontecia nos espaços da biblioteca Mário de Andrade: começava com uma performance na entrada, depois as pessoas se encaminhavam para o saguão, que estava envolto em fumaça, com a estátua que tem no meio do espaço toda coberta ${ }^{15}$, e ali o espetáculo se iniciava com uma cena de tourada. Logo depois, havia uma encenação de uma mãe de santo, a mãe Geni, que encomendava a um espírito, o Sombra, que atrapalhasse o casamento da filha do Governador, pois ele prometeu levar a mãe Geni no enterro do Papa e a esqueceu no aeroporto. Esse começo pode dar uma ideia da colagem singular de sobreposições de referências de que era

${ }^{15}$ Instalações de Arnaldo foram inspiradas em Christo (Christo Vladimirov Javacheff), artista plástico búlgaro que era conhecido, entre outras coisas, por embrulhar monumentos e construções. 
feita a dramaturgia. Para essa cena, usamos música de tribos da Mongólia com canto gutural.

Também havia uma instalação composta por quinhentos bichos de pelúcia, que traduziam o ambiente de luxo e futilidade da filha do Governador, Marinalva. Aqui havia a monumentalidade da proposta pela quantidade: tentamos coletar dois mil bichos, conseguimos quinhentos; mesmo assim, espalhados nas escadarias do saguão, as pelúcias davam uma atmosfera palaciana e onírica à biblioteca, que ficou quase irreconhecível com a fumaça, a estátua coberta e os bichos espalhados em um canto. Depois, "público e performers [percorriam] o hall e a antiga sala de leitura de jornais e revistas da biblioteca, cuja arquitetura reforça o ambiente palaciano" ${ }^{16}$. Ali era o gabinete do Governador Paulo Salim Maluco, personagem de Marco.

Fotografia 2 - Comendador Peçanha - Cia Zaum, 2005

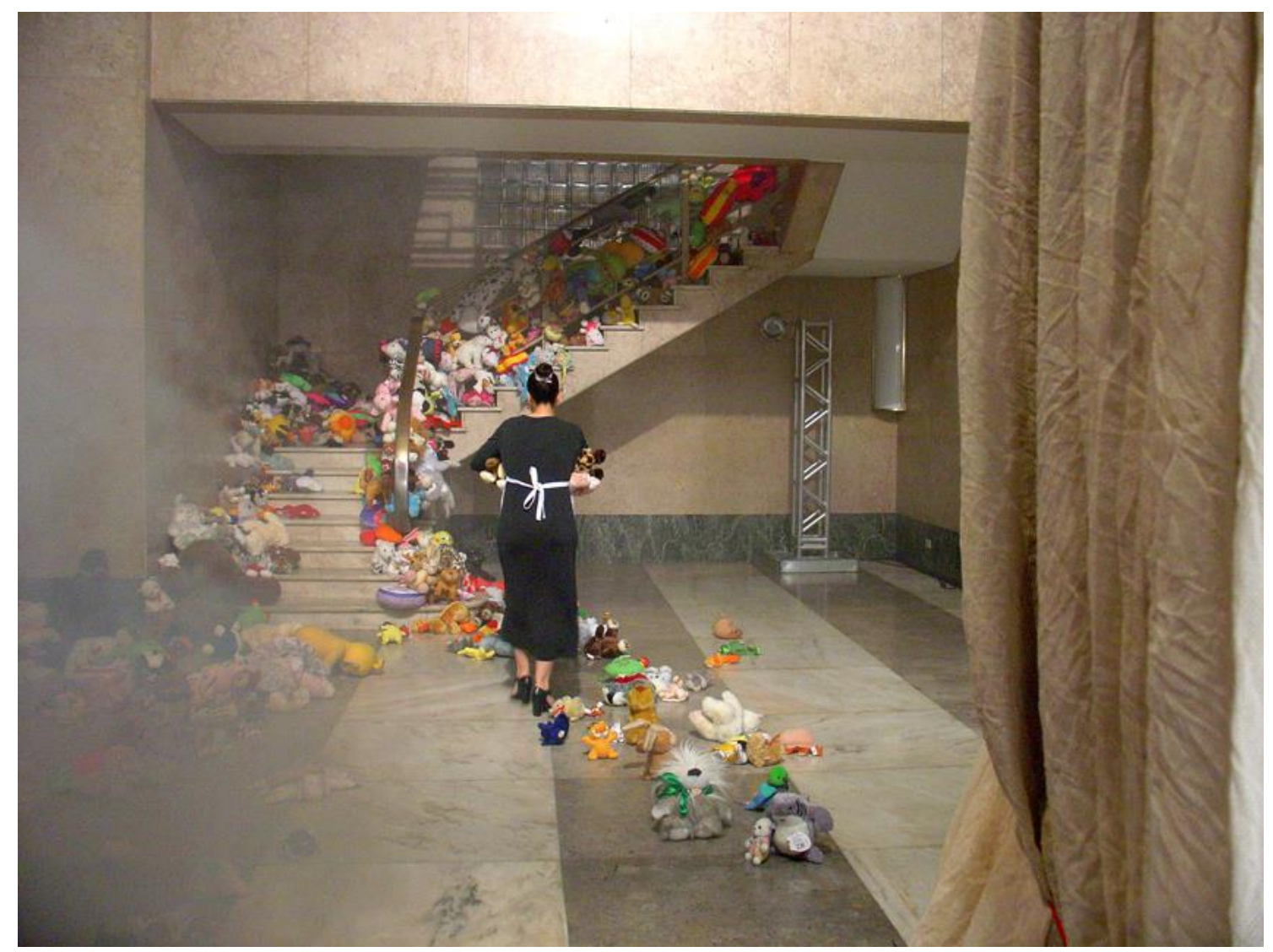

Fernanda Moura. Foto: Acervo pessoal.

\footnotetext{
${ }^{16}$ Release do espetáculo Comendador Peçanha.
} 
O produtor e curador Ricardo Fernandes assistiu ao espetáculo e nos mandou algumas impressões, que reproduzo aqui, pois descrevem com precisão e poesia, a ambientação e os efeitos das instalações, e a cena inicial da tourada:

\begin{abstract}
O saguão
A fumaça cria névoas, esconde, desterritorializa, inventa um outro real, irreal. O cerimonial está aberto para qualquer um, todos são ali doutores, todos são autoridades.

Coberto o poeta, enfaixado como uma obra velha de Cristo, um arremedo de Ponte Neuf, um pedaço do parlamento ali deixado, a obra cresce, no círculo fascista se torna gigante, ganhando contornos de monumento. Obra a ser imaginada como tudo aquilo que está prestes a começar. As centenas de bonecos no chão e na escada empilhados iluminam o mármore em cores também artificiais, e toda a grandeza do edifício ressalta, palácio se torna imediato. Tigres, pernalongas, porcos cor de rosas, seres fantásticos escapados do livro de seres imaginários de Borges se amontoam na escada, na Plaza de Toros tornada de cara.

\section{A tourada}

De palácio fascista a Plaza de Toros. Distância e identidade. Toureiro e seu discurso belo em dislexia. As frases não são inteiras, mas soltas, pescadas por cada um. Compostas em cada ouvido e cabeça um roteiro. Vem o touro: Picasso e Bispo. Grandiosos em medalhas baratas e papelão. Tauromaquia Fubá. Olé Glauber! A luta entre o homem e o bicho. As falas são como ilhas de sentido no meio do oceano. Deleuze pensando Espinosa, na impossibilidade de compreender em sua plenitude o melhor é se deixar levar pelo engano. Touro morto no chão. Bicho, homem e fera derrotado. Já estamos em pleno deslize de sentido, liquefazendo-se a plateia e o elenco. Todos bichos, todos touros todos toureiros. E o bicho morre não em flamenco, mas em pandeiro, grave e premonitório ${ }^{17}$.
\end{abstract}

A equipe da Biblioteca, especialmente Luís Francisco de Carvalho Filho (diretor da Biblioteca na época), Thaís Ruiz e Katia Bocchi, foi de uma parceria, confiança e coragem notáveis ao acolher nossas propostas sem restrições. Essas propostas incluíam usar os diferentes espaços da biblioteca para ensaios e apresentações, além de trinta pessoas da equipe, muitas das quais convivendo mais intimamente com a experiência da loucura, e uma instalação com duzentos escorpiões vivos.

A partir de associações do nome do Comendador corrupto, Peçanha, com a ideia de peçonha, Arnaldo trouxe a ideia de uma instalação com

\footnotetext{
${ }^{17}$ E-mail de Ricardo Fernandes após a apresentação de Comendador Peçanha.
} 
escorpiões vivos que seriam os bichos de estimação do Governador e ficariam em caixas de acrílico dispostos em seu gabinete. "Comendador Peçanha reúne em seu enviroment a simbologia dos escorpiões, sendo estes os agentes portadores de certo veneno, de certa malícia ou maldade característicos no jogo político e nas relações sociais" ${ }^{18}$.

Nossa proposta, além da relação sonora e temática de peçanha e peçonha, era a de deslocar o foco da questão psiquiátrica para outra que chamasse mais a atenção, como os escorpiões vivos. Além disso, também tínhamos em nossa constelação referências de artistas como Joseph Beuys, que trabalhava com a crueza e a imanência dos materiais (como feltro, mel e gordura, que usava em vários de seus trabalhos).

Essa proposta criou experiências para o grupo, como a visita que fizemos ao departamento de artrópodes do Instituto Butantã, que cedeu os escorpiões (tivemos que conseguir uma licença do lbama de transporte de animais silvestres, e tínhamos que, a cada apresentação, buscá-los antes e levá-los de volta ao Instituto).

Fizemos a visita para nos familiarizar com os bichos, mas também pela experiência. Além dos escorpiões, observamos: um almoço em que aranhas venenosas eram alimentadas uma por uma por senhoras simpáticas que depositavam a comida com uma pinça dentro de um copinho aberto (por onde as aranhas poderiam sair se quisessem, pelo menos assim parecia para uma pessoa que tem pavor de aranhas como eu); a sala cheia de caixas lotadas de baratas que são utilizadas como alimentação, e que tem um cheiro específico que eu nem sabia que existia (mas nunca mais esqueci o cheiro das baratas); a sala lotada de grilos, também usada para alimentação etc. Uma das biólogas que trabalhava lá nos chamou, feliz, para ver uma novidade que havia acabado de chegar no berçário. Abriu uma caixa e falou "olhem que lindo o meu bebê!", enquanto nos revezávamos para tentar olhar dentro, onde uma lacraia de uns cinco centímetros se mexia rapidamente.

Reproduzo um trecho do programa do espetáculo no qual é possível vislumbrar a construção do texto e o nosso processo de criação. Mesmo sendo criado a partir de um texto dramatúrgico com um enredo, o espetáculo tinha

\footnotetext{
${ }^{18}$ Sinopse do espetáculo Comendador Peçanha.
} 
uma característica performática, feita de fluxos pelo espaço e pelo tempo, pois a trama era cheia de reviravoltas temporais e espaciais, que dissolviam a linearidade, e muitas vezes o modo com que as cenas eram feitas era mais importante do que acompanhar as histórias em si. Também havia cenas improvisadas e personagens como o fantasma da primeira dama, ou Sombra: "figuras aparentemente dispersas no palácio pontuam o ambiente da performance, ora agregam sentido a um dia especial, ora desconstroem a possibilidade de uma narrativa linear prontamente inteligível"19.

Nesse work in process, experimentamos perder a discrição. Um caos organizado que cria condições para atrair os imprevistos, um sistema aberto onde cada um pode estabelecer seu próprio espaço expressivo, um universo vivo e entrópico, um organismo que não procura apenas respostas. Cada aresta tem sua função na performance; erros e acasos de ensaio são incorporados aos ossos do espetáculo, operações que radicalizam um princípio do teatro: uma apresentação nunca é igual a outra.

[…] Neste espetáculo, as fronteiras são móveis porque são constantemente atravessadas por multiplicidades: performance, psiquiatria, biologia, reinserção social, artes plásticas, conscientização política, fotografia, vídeo, mídias eletrônicas, psicologia, poesia, música, dança, teatro.

[...] A operação usada é semelhante à da collage/assemblage, acúmulo, coleta, encaixe de materiais vindos dos mais diferentes lugares: pedaços de outdoor, trechos de filmes da sessão da tarde, resquícios de brincadeiras de infância, seriados americanos, filmes de guerra e espionagem, histórias em quadrinhos, filosofia oriental, pedaços de falas - clichês que poderiam estar em muitos filmes e colagens do imaginário ${ }^{20}$.

O espetáculo Comendador Peçanha fez três apresentações na biblioteca Mário de Andrade, dias 4, 5 e 19 de novembro de 2005. Durante a temporada, fizemos uma exposição documental do nosso processo no vestíbulo da biblioteca, com imagens, desenhos e fotografias dos ensaios.

Essa foi uma experiência inicial com o universo da saúde mental e com o sistema público de saúde, o que traz uma série de especificidades a essa realidade, como um maior entrelaçamento econômico, social e psiquiátrico. O fato de ter sido minha primeira vivência mais próxima com a loucura fez com que fosse uma experiência inaugural muito intensa para se pensar algumas

\footnotetext{
${ }^{19}$ Texto do programa do espetáculo Comendador Peçanha.

${ }^{20}$ Ibidem.
} 
práticas que surgiram empiricamente e, mais tarde, mostraram-se valiosas nesse tipo de processo, na construção de um modo de criação.

Fotografia 3 - Comendador Peçanha - Cia Zaum, 2005

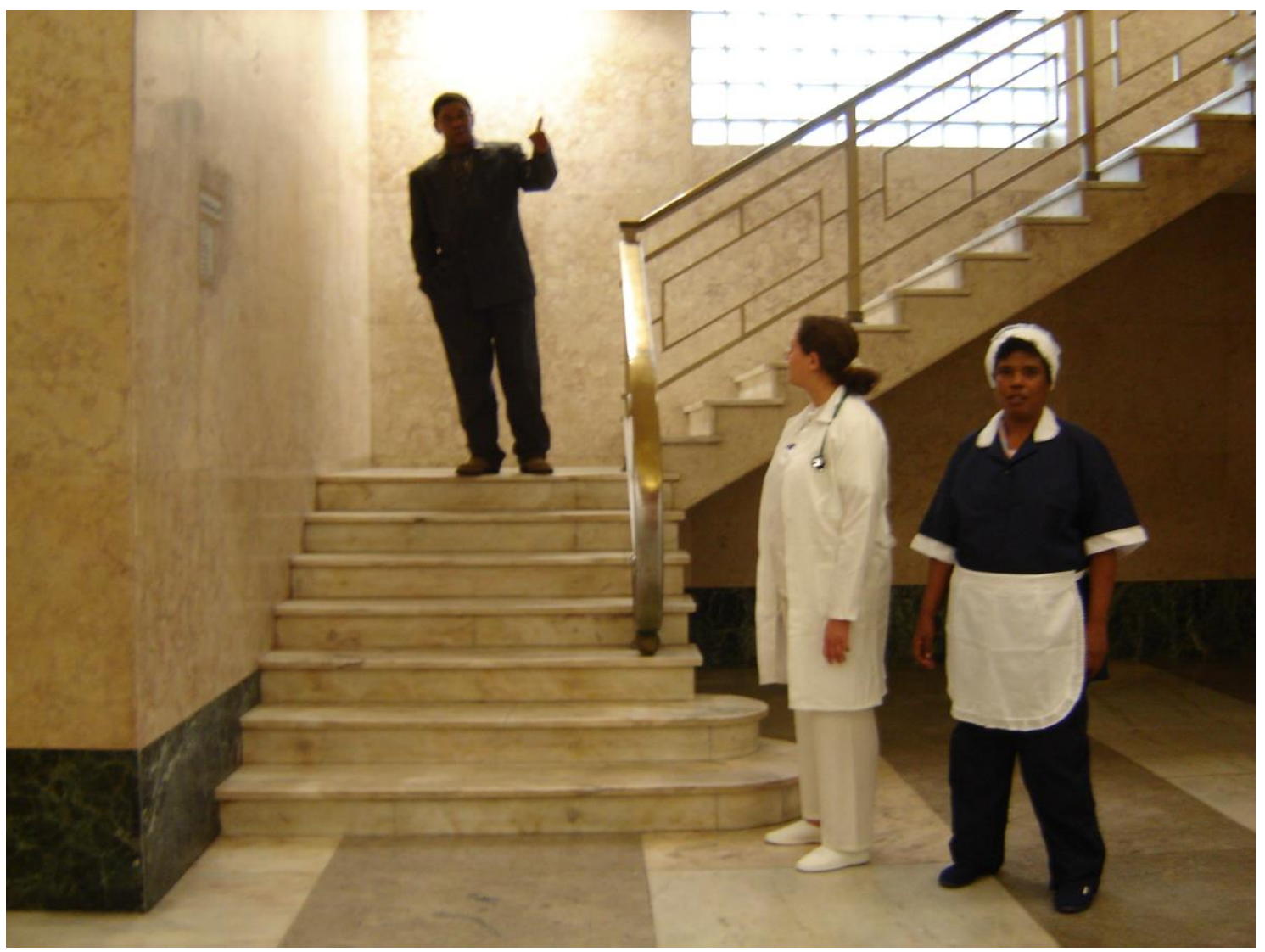

Teodomiro Arcanjo, Crystian Costa e Elza Martins. Foto: Acervo pessoal.

Esse foi um momento importante na minha vida e em meu trabalho, pois abriu um caminho de experimentação. A formação que havia tido na universidade e as experiências relatadas até aqui de alguma forma ajudaram, mas não havia nada que nos desse um método seguro ou nos preparasse para lidar com algumas questões estéticas e existenciais que aquele coletivo trazia. A cooperação entre nosso núcleo de criação ancorou o processo, e as nossas reuniões que aconteciam após os ensaios, carinhosamente chamadas entre nós de HN, iniciais de hospital noite, foram valiosas como metabolização dos acontecimentos e espaço de criação.

Nessa época, eu havia visto uma apresentação da Cia. Ueinzz, Gothan$S P$, dirigida por Renato Cohen e Sérgio Pena, e aquilo que se insinuava quando vi a performance de Renato na Casa Modernista aqui era potencializado: uma gramática cênica inédita, com figuras cujas lógicas 
próprias se entrelaçavam em uma linguagem crua e sofisticada ao mesmo tempo, em uma constelação de momentos que surgiam e se desmanchavam e que eram feitos de uma de beleza poética e existencial. Foi um dos trabalhos que mais impressionou: um espanto que abre caminhos.

A companhia tem entre seus integrantes terapeutas, performers, filósofos e pessoas das mais diversas áreas, idades, corpos, experiências, muitas delas que têm ou tiveram uma proximidade com o universo da desrazão: "É constituída por um coletivo de atores com trajetos de vida os mais variados. Cada um traz, de seu percurso de fragilidades e tresloucamentos, ou de seus colapsos de vida, uma energia e um repertório singulares, que nutrem a criação do grupo". ${ }^{21}$

Peter Pál Pelbart, filósofo e um dos fundadores do grupo, tem vários estudos sobre a relação entre arte, subjetividade e loucura. Seus escritos sobre a companhia trazem a intersecção de clínica, estética e filosofia, e conseguem traduzir o impacto da experiência vivida:

É por um triz que tudo acontece, mas esse por um triz não é ocultado - ele subjaz a cada gesto e o faz vibrar. Não é só que a segurança do mundo se vê abalada, mas esse abalo introduz no mundo (ou apenas the desvela) seu coeficiente de indeterminação, de jogo e de acaso ${ }^{22}$.

Acredito que esse "por um triz" seja um dos fatores que produz a beleza de se criar uma linguagem própria por meio das particularidades de cada pessoa, e que deixa aparecer a indeterminação que nos cerca; há nesse "triz" uma chave para essas experiências com os coletivos heterogêneos. É um estado de suspensão no qual parece que tudo pode acontecer, ou pode não acontecer, e essa imprevisibilidade faz a gente ficar mais vivo. Tentar se equilibrar sem cair, seja para o lado da loucura que engole tudo, ou de uma formatação domesticadora da linguagem, é um aprendizado que (também) começou ao ver aquele espetáculo.

Mais adiante nesse mesmo texto, Pelbart descreve como essa experiência

21 OCUPAÇÃO Ueinzz, Sesc Paulista, 2011. [Catálogo]. São Paulo: Sesc, 2011, p.15. Disponível em: <https://issuu.com/varzeadesign/docs/ocupacaoueinzz>. Acesso em: 2 mar. 2020.

${ }^{22}$ PELBART, Peter Pál. A vertigem por um fio. São Paulo: lluminuras, 2000. p.120. 
[...] se deu na confluência de dois grandes vetores que atravessam nossa cultura. O primeiro é o do teatro, com seu cortejo de magia e assombro, esse espaço ritual e sagrado, campo privilegiado de experimentação estética. O segundo vetor é o da vida quando ela experimenta seus limites, quando ela tangencia estados alterados, quando é sacudida por tremores fortes demais, por rupturas devastadoras, intensidades que transbordam toda forma ou representação, acontecimentos que extrapolam as palavras e os códigos disponíveis, ou o repertório gestual comum, mobilizando linguagens que põem em xeque a língua hegemônica, que reinventam uma vidência e uma audição ${ }^{23}$.

O que eu tinha visto da Cia. Ueinzz conseguia colocar na prática esse exemplo de síntese entre os vetores, do teatro e da vida, "quando ela [vida] está às voltas com o irrepresentável, ou com o inominável, ou com o indizível, ou com o invisível, ou com o inaudível, ou com o impalpável - com o invivível"24.

Com a morte de Renato Cohen e a saída de Sérgio Pena, a companhia ficou sem alguém na direção. Em 2007, Cássio, e depois eu, nos juntamos ao grupo, nas funções de diretor e codiretora e dramaturga. Nesse início, me senti privilegiada e um pouco intimidada por estar naquele lugar, com um grupo que admirava tanto e de longe. Durante o processo, esse sentimento se dissolveu, e também acabamos nos dividindo em ambas as funções e criando conjuntamente, entre nós e com todo o grupo, o espetáculo Finnegans Ueinzz, a partir da obra Finnegans Wake, de James Joyce.

O texto que deu origem ao espetáculo é um livro de setecentas páginas, que demorou dezoito anos para ser concluído e foi escrito em sessenta línguas, com centenas de histórias e personagens que se misturam, sobrepõem-se, aparecem e desaparecem, e é um marco da literatura experimental. De acordo com Joseph Campbell,

É um estranho livro, um misto de fábula, sinfonia e pesadelo um monstruoso enigma a acenar imperiosamente dos abismos sombrios do sono. Sua mecânica assemelha-se à de um sonho, um sonho que libertou o autor das necessidades da lógica comum, possibilitando-Ihe comprimir todos os períodos da história, todas as fases do desenvolvimento individual e racial, em um desenho circular, de que cada parte é começo, meio e fim. No torvelinho dessa gigantesca charada, efígies

\footnotetext{
${ }^{23}$ Ibidem, p.122.

24 Ibidem. p.122
} 
obscuras passam ressoando, desaparecem em horizontes nublados, e são substituídas por outras imagens, vagas, mas semiconscientemente familiares. Como em um palco giratório, heróis mitológicos e eventos da mais remota antiguidade ocupam os mesmos planos espaciais e temporais que as personagens modernas e os acontecimentos contemporâneos. Todos os tempos acontecem simultaneamente; Tristão e o Duque de Wellington, Adão e Humpty Dumpty fundem-se num único objeto da percepção. Múltiplos significados estão presentes em cada linha; alusões encadeadas a palavras e frases-chave são entretecidas como temas de uma fuga musical no molde da obra. Finnegans Wake é um prodigioso, multifacetado monomito; não apenas o cauchemar de um cidadão de Dublin, mas a saga onírica da humanidade manchada de culpas, em evolução ${ }^{25}$.

O que nos interessava nessa obra era, entre outras coisas, o seu potencial oceânico de disparador de estímulos e de dispositivos de criação de cenas. Os assuntos e as possibilidades eram tão vastos, que o grupo brincava que a gente poderia fazer qualquer coisa que quisesse, porque ia ter algum trecho do texto que se relacionaria com aquilo. Mesmo com toda essa abertura, o texto nos impulsionava em determinadas direções criativas, às vezes partindo da ideia mais simples, como narrar os sonhos: para Joyce, se sua obra Ulisses se passa durante um dia, Finnegans Wake seria a noite desse mesmo dia. Além dos procedimentos relacionados ao texto, também experimentávamos outras cenas e improvisações que vinham do grupo. Aos poucos a coerência da obra foi se formando.

O processo de criação era livre, assim como as dinâmicas dos ensaios: quando sentimos que a coisa estava ganhando corpo, decidimos abrir o processo, e assim pudemos fazer várias pequenas temporadas, aberturas do nosso work in process, e constantemente modificar sua estrutura. O elenco era formado por aproximadamente vinte pessoas, algumas entraram ou saíram durante o percurso. Durante a criação do espetáculo, trazíamos estímulos para a criação das cenas, que poderiam ser textuais, imagéticos ou sonoros, e a partir disso fazíamos improvisações, que poderiam durar muito tempo e tomar rumos inesperados, ou acabar de repente. O grupo tinha uma dinâmica própria forte de sustentação desse lugar "por um triz", de modo que as improvisações

${ }^{25}$ CAMPBELL, Joseph; ROBINSON, Henry Morton. Introdução a um assunto estranho. In: CAMPOS, Augusto de; CAMPOS, Haroldo de. Panaroma do Finnegans Wake. São Paulo: Perspectiva, 2001. p.106-107. 
muitas vezes eram esteticamente potentes, mas ao mesmo tempo poderiam tocar em lugares delicados, de atravessamentos pessoais. Em nossos procedimentos de criação, havia um constante equilibrar-se entre a linguagem e o seu desmanche, e imaginar modos de lapidar essas intensidades, assim como compor coletivamente uma cena preservando as particularidades e desvios.

Havia já uma dinâmica entre as pessoas do grupo que, se por um lado procurava manter a coesão grupal, não era feita de forma apaziguadora, mas convivendo com os atritos, os ruídos, dando espaço para as diferentes manifestações do ser e ainda assim formando um coletivo feito dessas assimetrias. De acordo com Erika Inforsato, integrante da companhia, "este alojamento provisório dispara muito mais as inquietudes, perturbações, angústias, forças e vitalidades [...]. Espera-se nada, espera-se tudo, sem saber ao certo o que isto significa" ${ }^{26}$. Esse período foi de bastante troca com as pessoas, criamos um material cênico diversificado, com cenas estruturadas e outras improvisadas, e acredito que o espetáculo tinha uma ligação com o caleidoscópio joyceano, mas da nossa maneira.

Em 2008, estreamos Finnegans Ueinzz e fizemos algumas temporadas. Em São Paulo, nos apresentamos na galeria b_arco e no Sesc Paulista, em um projeto chamado Ocupação Ueinzz, com dez dias seguidos de apresentações e debates com pensadores e artistas de várias áreas. No Rio de Janeiro, fizemos apresentações no Sesc Copacabana e nos apresentamos em Helsinque, na Finlândia, em no Baltic Circle International Theatre Festival. 0 texto que fizemos para o programa para a temporada do Sesc Paulista nos dá uma ideia da dimensão múltipla do espetáculo,

Finnegans Ueinzz é sobre energia e reinvenção. A nova experiência do grupo Ueinzz parte do universo de James Joyce. Diversas camadas de linguagem são fundidas, colocadas em choque ou sobrepostas para formar a cena polissêmica Ueinzz, assim como muitas línguas misturam-se para compor a sinfonia-sonho de Joyce. [...]

$\mathrm{Na}$ produção de sentidos e na criação das cenas, percorremos vários caminhos. Os textos Finnegans Wake e Ulisses nos serviram como dispositivos para processos de diferentes ordens que convivem sem hierarquia. O espectador é convidado a ter um olhar produtivo sobre a obra, há pistas,

${ }^{26}$ INFORSATO, Erika Alvarez. Desobramento: constelações clínicas e políticas do comum. São Paulo, 2011. Tese (Doutorado) - Universidade de São Paulo. p.20. 
propostas, que podem ser seguidas ou subvertidas. Durante o espetáculo os performers estão sempre em percurso, que às vezes toma a frente, imanta e outras vezes está lá como uma sombra, um duplo, uma figura-fundo. A presença das personas e subtramas cria uma estrutura aberta, que inclui, amplia e muitas vezes implode 0 dramático, pelo seu próprio esgotamento. O que vemos então, desses escombros ilusionistas, é o surgimento de uma cena onde as expectativas convivem com as ficções das realidades. Chegamos por fim a um estado onde percebe-se o inevitável: as ficções são biográficas e a realidade é ficciona ${ }^{27}$.

Podemos ver aqui alguns elementos que vinham sendo metabolizados desde a época de Renato Cohen: criação hipertextual, configurações cênicas que se formam e se desmancham aos olhos do público, por exemplo, todo o elenco ficava sentado em cadeiras no fundo do palco, em dois grandes grupos, e de lá saiam e voltavam. Poderia acontecer de conversarem sobre as cenas, ou interagir ou mesmo entrar inesperadamente em determinadas cenas. Outra característica eram uma estrutura aberta de cenas que se relacionam, mas não formam uma linearidade, figuras que permeiam o espetáculo ora na frente ora no fundo e colagem de elementos "disparatados", heterogêneos, na dramaturgia.

Essas experiências apontavam para uma heterogeneidade que não está presente apenas nas diferenciações produzidas a partir das pessoas, mas também é matéria da dramaturgia, da encenação e dos diversos elementos da cena. Os processos criativos aos poucos engendravam a ideia da produção de heterogeneidade como linguagem.

As temporadas do espetáculo, especialmente a do Sesc Paulista, que teve dez apresentações seguidas, a viagem de todo o grupo à Finlândia, assim como Kafkamachine, o experimento que fizemos (junto a outros dois grupos de diferentes partes do mundo: Presque Ruines, da França, e Mollecular Organization, da Finlândia) durante 26 dias em um navio, que incluía apresentações em Portugal, Santos e São Paulo, foram experiências também transformadoras e cheias de desdobramentos estéticos, clínicos e existenciais. Contudo, para esta dissertação, decidi recortar o processo de criação do

\footnotetext{
${ }^{27}$ OCUPAÇÃO Ueinzz, 2011. p.11,
} 
Finnegans Ueinzz, que cabe melhor na proposta de se investigar procedimentos de criação com coletivos heterogêneos.

Fotografia 4 - Finnegans Ueinzz - Cia Ueinzz, 2009

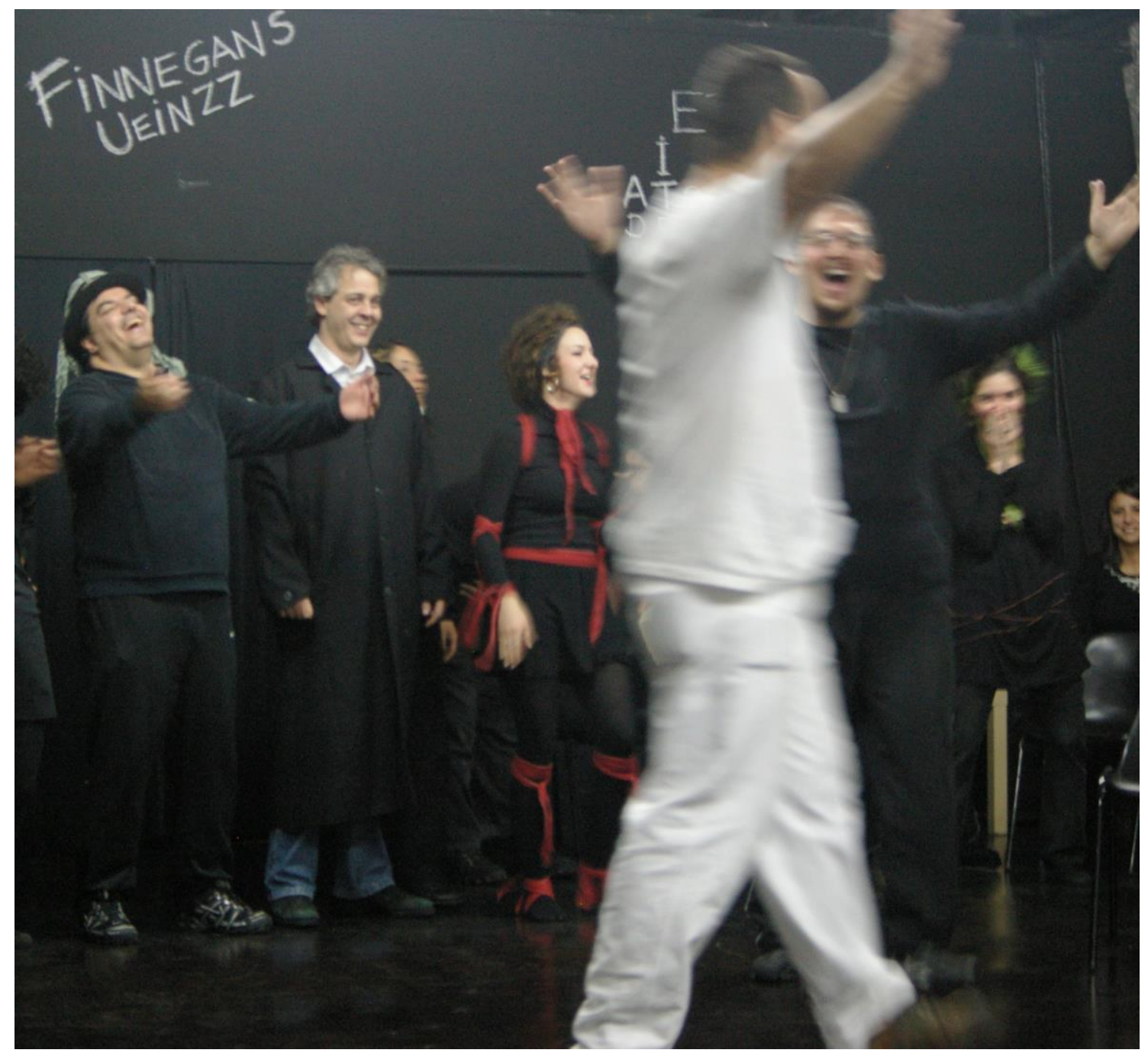

Da esquerda para direita: Onéss Cervelin, Eduardo Lettiere, Amélia Montero, Guilherme Ribeiro e Ana Goldenstein. Foto: Luciane Torres.

A partir dessas experiências, em 2011 começamos, eu e Cássio Santiago, a ministrar o curso de performance que surgia no MAM, dentro do programa lgual Diferente, que é formado de "cursos de arte gratuitos que convidam o público a fazer e pensar a arte em um ambiente acessível a todos, independentemente de suas condições física, social ou psíquica"28.

${ }^{28}$ LEYTON, Daina (org.). Educação e acessibilidade: experiências do Museu de Arte Moderna de São Paulo. São Paulo: Museu de Arte Moderna de São Paulo, 2018. Publicação do Museu criada como parte da comemoração de 20 anos do Programa Igual Diferente. 
Ministramos o curso até 2015. De 2018 ao presente momento, retomei as atividades, e atualmente ministro o curso junto com Leonardo Castilho.

Daina Leyton, educadora e psicóloga que era coordenadora do Igual Diferente (atual coordenadora do MAM Educativo), estabeleceu desde o início uma parceria artístico-pedagógica na qual imaginamos conjuntamente as atividades. O coordenador do Igual Diferente hoje é Gregório Sanches (que era educador da equipe), e essa atitude de parceria se mantém, de modo que durante $\mathrm{o}$ processo podemos pensar juntos as necessidades e fazer as transformações necessárias, de acordo com as características de cada turma e as experiências adquiridas durante os anos de curso. Em um texto em que relata o início do programa, Daina descreve que

[...] o rumo que o curso iria tomar era definido de acordo com a peculiaridade do grupo de alunos, e havia um investimento permanente na construção de um ambiente [...] onde vínculos de confiança e afeto pudessem ser estabelecidos, e as proposições artísticas, desenvolvidas ${ }^{29}$.

Fomos durante esse tempo experimentando diversas formas de estar e criar junto: os cursos do Igual Diferente possibilitam uma pesquisa continuada dos educadores e dos artistas professores, dando condições para que os participantes dos cursos possam desenvolver um processo de criação autoral. Além disso, as reuniões mensais com a pedagoga Fátima Freire, com os professores dos cursos e com os coordenadores do programa, são um espaço importante de trocas e aprendizados.

$\mathrm{Na}$ trajetória do curso de performance, investigamos diversas abordagens, temas e modos de criação. Temos um "núcleo duro" que se mantém até hoje, com participantes que estão desde o início do curso e uma parte de pessoas que saem e entram a cada ano. Durante esse período, fizemos algumas performances abertas ao público, um filme, um fanzine ${ }^{30} \mathrm{e}$ participamos da mostra Museu dançante, em 2014, todas realizadas em espaços internos e externos do MAM e do parque lbirapuera, onde o museu é localizado.

\footnotetext{
${ }^{29}$ Idem. Igual Diferente. São Paulo: Museu de Arte Moderna de São Paulo, 2018. p.14.

30 LEYTON, Daina (org.). Zine 20 anos Igual Diferente. Disponível em: <https://mam.org.br/publicacoes/livros/>. Acesso em: 17 jul. 2020.
} 
Fotografia 5 - Performance 3062014 - Igual Diferente - MAM, 2014

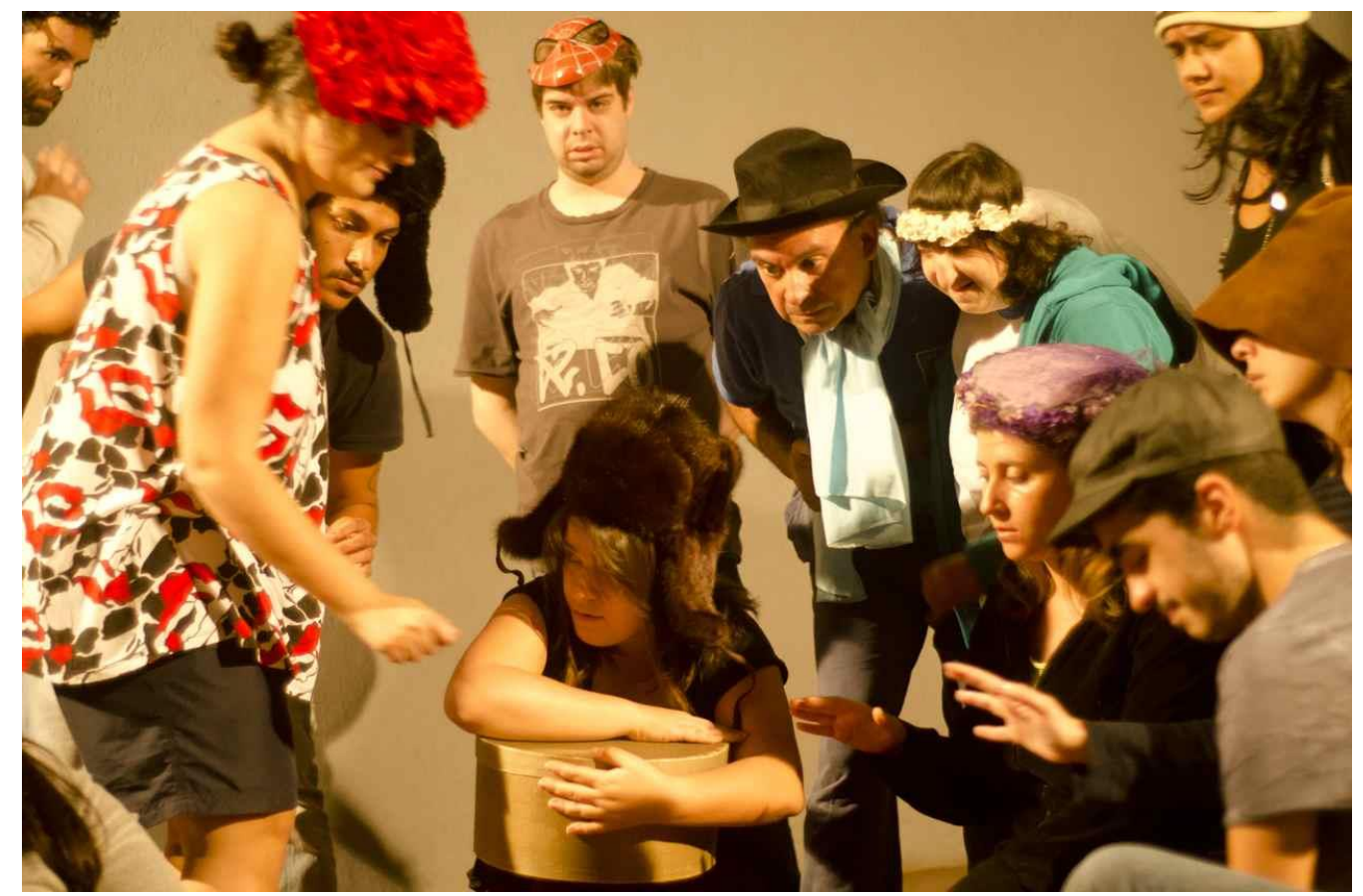

Da esquerda para direita, de cima para baixo: Daniel Gonçalves, Olivia Lerner, Leonardo Castilho, Gabriel Meca, Paulo Dersu, Ana Cardelli, Mari Dotti, Mariana Castilho, Lucia A. Jolk, Carol Fomin, Pedro Machado. Foto: Karina Bacci.

Durante esses anos, experimentei procedimentos dos mais diversos para dar conta de grupos tão heterogêneos. Minhas práticas artísticopedagógicas aconteceram empiricamente, por meio de tentativa e erro, o que tornou o percurso certamente mais difícil, mas também único. Nesse período, comecei a perceber que havia aí um método sem método, no qual a relação entre estética e clínica, entre arte e loucura, experimentada na prática, tinha algumas características que não se restringiam apenas ao grande conjunto da performance, ou da clínica, por exemplo, e essa confluência de áreas e linguagens merecia um olhar mais detido. Essa reflexão já vinha acontecendo aqui e ali: por exemplo, escrevi um artigo sobre dispositivos artísticos pedagógicos na revista Vocare $^{31}$, quando trabalhava no programa Vocacional como artista-orientadora ${ }^{32}$. Esse artigo descrevia procedimentos para utilização dos sonhos como material criativo em processos coletivos.

31 BAND, Elisa. Sonhos. Revista Vocare, ano1, n. 1, nov. 2011. p.45. Disponível em: <https://docero.com.br/doc/n515ne0>. Acesso em: 15. jul. 2020.

${ }_{32}$ O Programa Vocacional é um projeto da Secretaria Municipal de Cultura em parceria com a Secretaria Municipal de Educação que foi criado em 2001 e oferece gratuitamente oficinas de várias linguagens artísticas (dança, música, teatro e, mais recentemente, literatura) para 
Esse olhar sobre os processos continuou a ganhar corpo (corpo teórico, porque na prática ele já vinha acontecendo bem antes) nos relatórios do curso do MAM (havia uma proposta de usar esses relatórios para reflexão, e de uma maneira desburocratizada) e em uma publicação que fizemos do programa Igual Diferente, na qual percebemos que buscávamos

[...] legitimar o outro em sua alteridade mais radical, sem colocá-lo no papel de exótico ou extravagante, mas colocandoo do lado de dentro, no lugar de criador, sua extravagância é, então, olhada como força poética de invenção, seu exotismo é transformado em autenticidade, em invenção de novos $\operatorname{modos}^{33}$.

Essas reflexões apontavam para a percepção da potência cênica, existencial e estética desses coletivos, e como os processos criativos com eles poderiam instaurar uma gramática cênica própria, ao explodir uma gramática cênica mais usual e instaurar outra, assim como a poesia faz com a sintaxe. $O$ percurso do Igual Diferente me deu a possibilidade de verticalizar essas investigações no tempo (cursos continuados de dez meses por ano, há oito anos) e no espaço, tanto físico (no atelier, na marquise, no parque e em outros espaços do museu) quanto o espaço simbólico e político, ao permitir que corpos que geralmente não têm acesso ou são invisibilizados possam escapar de categorias estigmatizantes e experimentar-se como criadores e autores. E continua sendo um lugar no qual podemos experimentar como é ser um coletivo que se transforma constantemente a partir dos diferentes modos de existir e de criar que o compõe.

Paulo Araújo da Cruz, mais conhecido como Dersu, foi meu aluno no programa Vocacional de 2008 a 2011, e iniciamos uma colaboração artística que continua desde então. Ele participa das aulas do Igual Diferente desde 2012. Além de geógrafo e performer, também é escritor e dramaturgo, e costuma fazer relatos singulares das nossas experiências. Acredito que ele consegue falar de coisas que escapam a outros olhos, então termino esse

pessoas interessadas e grupos de diversos pontos de São Paulo (Casas de Cultura, bibliotecas, teatros, CEUs etc.). É um projeto de relevância na cidade, que, com suas propostas artístico-pedagógicas, promove trocas culturais entre diversas áreas, incentiva processos artísticos e dá protagonismo a manifestações e iniciativas de várias linguagens e regiões da cidade. Hoje o programa não atua mais da mesma forma e está mais enfraquecido e com menos alcance do que na época em que participei, de 2007 a 2011.

${ }_{33}$ BAND, Elisa; SANTIAGO, Cássio D. Performance e reinvenção de si. In: Igual Diferente. São Paulo: Museu de Arte Moderna, 2015. p.122. 
trecho do percurso com um pedaço de suas reflexões sobre o nosso curso (quando os encontros aconteciam às segundas-feiras):

É de segunda mão, mas vai longe.

O Pedro tem algo de atores mexicanos tipo Cantinflas e o Chaves. Eu acho que ele não vai receber esse e-mail, nem a Zeu. Ele é muito alegre e tem uma risada franca.

O Espaço nosso é muito louco, temos que reapresentar aquele espaço de forma artística e os atores brincarem... Eu vou tirar uns xerox de umas fotos que têm no livro chamado Bauhaus. Têm poses, ocupação dos espaços, atores como marionetes, dança da caixa, efeito luminoso, pantomima com figura e bastidores transparentes.

Luz... Luzes na RIBALTA, luzes que marcam espaço de forma firme. De um lado você vê tudo; do outro você vê nada.

A Carolina tem uma cara tão bonita e vocês veem com seus próprios olhos o que está acontecendo... Por que Carolina? Tem uma música que se tocada junto dela atuando daria um puta contraste. Mas eu prefiro a cara da Carolina. O mundo está muito feio, precisamos de beleza e ela alegre se sai muito bem.

No próximo encontro temos o aniversário do Gabriel. É tudo o que nós queríamos. Para começar temos que fazer-inventar para o grupo desfrutar o famoso espetáculo Birthday-Play, que pode ser traduzido por Peça de Aniversário. Como é essa peça? Nós somos em dezoito, imagine fazer umas dez apresentações desta nova forma-conteúdo, desse novo mobile, desse novo pagode, o nosso parangolé. Arte é relação. Relação entre a gente e os outros. Vamos bolar um jeito entre nós, a criação de uma nova linguagem, a nossa língua. $O$ Gabriel vai fazer TRINTA. Vocês viram como ele puxou o exercício, aquele movimento de cintura que ele deu. As pernas meio curvadas, o jeito que ele coloca a cabeça. Eu gosto deste gesto, me dá impressão de liberdade... E que tudo mais vá para o inferno. Quais os adereços de cena que vamos levar para esse TRINTA DE JUNHO DE 2014. Vejam que quando você coloca uma certa data você chama o dramático: É agora ou nunca? $O$ quê? Alguém tem que saber nessa companhia. Tem que ser o ANIVERSARIANTE. Não sei.

Que os olhos do MAM estejam pousados sobre todos nós ${ }^{34}$.

No inicio de 2014, propus um curso de extensão na SP Escola de Teatro - Centro de Formação das Artes do Palco, chamado Estudos e criação em performance/live art. $\mathrm{Na}$ descrição do curso, destaquei que era para pessoas interessadas de todas as áreas e formações. Naquele ano, houve muita procura, e entre as quatrocentas pessoas inscritas, em vez de privilegiar as qualificações profissionais - mas também as levando em conta - optei por uma seleção que abordasse uma possível variedade de experiências e corpos. Ter

\footnotetext{
${ }^{34}$ Relato de Paulo Araújo Cruz, o Dersu, sobre encontro do curso Igual Diferente em 2014.
} 
que escolher trinta pessoas entre tantos inscritos envolve formas de valoração que legitimam uma certa instância da vida da pessoa, enquanto outras importantes não constam. Acabei por selecionar uma amostragem de pessoas que não fosse somente pautada em qualidades ou grau "oficial" de realizações, mas pensando também em heterogeneidade, numa tentativa de olhar nas entrelinhas outras qualidades, como experiências de vida, curiosidade, abertura. Concretamente, procurei ter uma amplitude de gênero, raça, classe social, profissão e idades. O grupo selecionado incluía uma terapeuta lacaniana, um físico que estava fazendo doutorado em meteoritos, um geógrafo-dramaturgo (o Dersu novamente!), uma bióloga, uma pessoa da área da programação de computadores, uma bailarina clássica, um dançarino de butoh, um pedreiro, uma "dona de casa", uma performer não binária, atores e atrizes, performers, um colombiano que trabalha com arte com dependentes químicos etc. É bom observar que o achatamento das descrições das pessoas é para dar uma pequena ideia de diversidade, que ultrapassa esses predicados. Era um risco e uma aposta experimentar conduzir um processo com esse grupo.

O grupo começou com trinta pessoas e após as três semanas de atividades (três horas por dia de segunda a sábado), terminou com 29 pessoas, o que foi uma surpresa. Em nossa avaliação final sobre o curso, muitas pessoas comentaram a riqueza e o inesperado das trocas que essa diversidade humana gerou.

Após esse curso, um grupo de aproximadamente dezoito pessoas continuou se encontrando semanalmente, e criamos o Grupo de Estudos e Criação em Performance (GECEP). Pude fazer um segundo módulo do curso no início de 2015 com essas pessoas e mais algumas novas que acabaram participando do grupo também. O número aproximado de pessoas que faziam parte do grupo é porque, entre outras coisas, interessava-nos, mais do que criar produtos artísticos, experimentar formas de ser um coletivo, tentar criar uma dinâmica grupal mais aberta, na qual não houvesse a obrigatoriedade de uma mesma participação para todas as pessoas. A participação poderia ser mais assídua ou flutuante, de acordo com as possibilidades e desejos de cada pessoa. Como desdobramento de nossas investigações, criamos e apresentamos as performances 7 bilhões e um, em 2014, no Sesc Pompeia, 
dentro da mostra Multitudes, e a performance Killing MySelfie, em 2015, no Centro Cultural Banco do Brasil, parte da mostra Contaminação.

Fotografia 6 - Performance 7 bilhões e um - Grupo de estudos e criação em performance, 2014

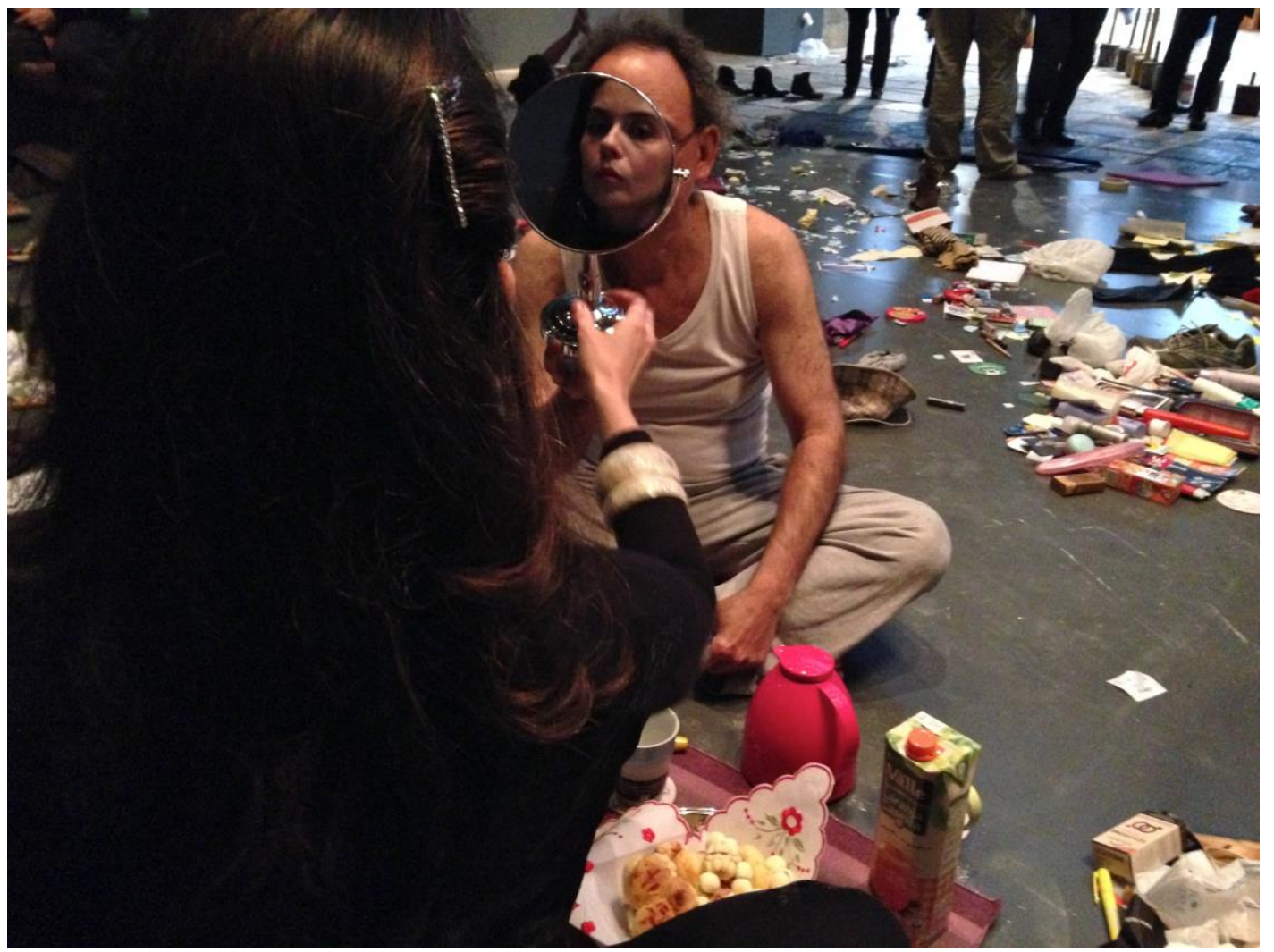

Paulo Dersu e Tereza Rabelo. Foto: acervo pessoal.

Fazíamos uma série de práticas, exercícios de performance, de dança, propostas que as pessoas traziam, encontros nos quais só conversávamos etc., em uma espécie de deriva criativa que tomou corpo por duas vezes nas performances citadas acima. Em nossos processos, procurei diluir a função da direção, de um modo que as pessoas poderiam trazer contribuições e sugerir as direções a serem tomadas, o que aconteceu algumas vezes, mas não sei o quanto conseguimos realizar isso, pois a forma com que o grupo nasceu estava muito ancorada nas minhas propostas. Essa partilha da direção procurava horizontalizar as relações. Não significava uma direção coletiva, mas uma possibilidade de troca de funções, de acordo com as necessidades e o desejo de cada pessoa e do projeto em questão. Uma pessoa poderia dirigir um projeto específico e ser performer do seguinte, por exemplo. Estávamos caminhando para essa autonomia, mas fui morar fora do Brasil em 2015 e o 
grupo ficou em suspenso: não continuou, mas também não acabou. Estamos em um estado de hibernação profunda; o grupo pode se juntar novamente ou então se dissolver de vez. Pelo tempo que o grupo não se encontra, pode-se dizer que acabou, mas pelas mensagens que recebo aqui e ali imaginando futuros desdobramentos, ainda considero uma (remota) possibilidade que 0 grupo reemerja de alguma forma diferente ${ }^{35}$.

De 2015 a 2016, passei sete meses em uma residência chamada Akademie Schloss Solitude, localizada em um castelo perto de uma floresta (na região sudoeste da Alemanha). A proposta da residência é que poderíamos usar aquele tempo e espaço para "refletir livre das pressões cotidianas", o que não aconteceu. É sabido que se alguém pedir a você que não pense em um elefante, a próxima coisa que você vai pensar vai ser um elefante. E também, vindo do Brasil, as pressões cotidianas estão tão grudadas em nós que não se descolam assim facilmente. Depois de um tempo você (aparentemente) esquece o elefante. Só nesse momento, pude aproveitar esses meses como uma espécie de longo parênteses, no qual juntei material para uma performance que pretendo fazer, mas que tem um tempo mais lento de amadurecimento. Além disso, esse tempo suspenso permite que se tenha uma visão ampliada: parece que quando você se distancia do seu habitat, consegue ver detalhes que, naturalizados, passavam despercebidos.

Com o distanciamento do país e das minhas atividades cotidianas pude ver como nós temos que improvisar na vida e como esse improviso gera um estado constante de alerta e de tensão, mas também gera criatividade ao se ter que inventar saídas o tempo todo (e estou falando de um lugar muito privilegiado de pessoa branca e classe média). Havia aproximadamente quarenta pessoas de vários países: Grécia, Polônia, Finlândia, Cuba, Suíça, México, Croácia, Estados Unidos, Índia e Alemanha. Havia um costume de que cada novo residente fizesse uma apresentação de sua pesquisa e/ou trajetória para os demais. Ao preparar a apresentação, pude delinear um pouco mais 0

35 Em 2015, as pessoas que estavam no grupo eram: Abmael Henrique de Sousa, Ângela Adriana, Carlos Gutierrez, Jaqueline Mazuchelli de Souza, Jessica Ferraz Ornellas, Leandro Rossato, Lucimara Amorim, Maikon Sabino, Marcelo Dávilla, Maria Tereza Rabelo, Mariane Miguel, Marilia Simões do Nascimento, Pamela Regina Pereira da Silva Gentile, Paulo Rogerio Araújo Cruz (Dersu), Rubya Caroline Lima Ferreira. 
percurso que vinha se trilhando com os coletivos heterogêneos, e também perceber as particularidades desse tipo de prática.

Em 2016 fui convidada para ser diretora de teatro da ONG Ser em Cena, que atende pessoas com afasia, um distúrbio de comunicação que acontece por uma lesão no cérebro e causa alterações na linguagem, podendo variar muito a cada caso. Quando entrei eram aproximadamente 65 pessoas atendidas pela ONG, divididas em três turmas, de idades, formações e possibilidades expressivas variadas. A Ser em Cena oferece atendimento gratuito para as pessoas, que passam por uma entrevista para ver em que turma se encaixam melhor, e as três turmas participam de um espetáculo teatral apresentado anualmente ${ }^{36}$.

Fotografia 7 - Do outro lado do oceano - Ser em Cena, 2016

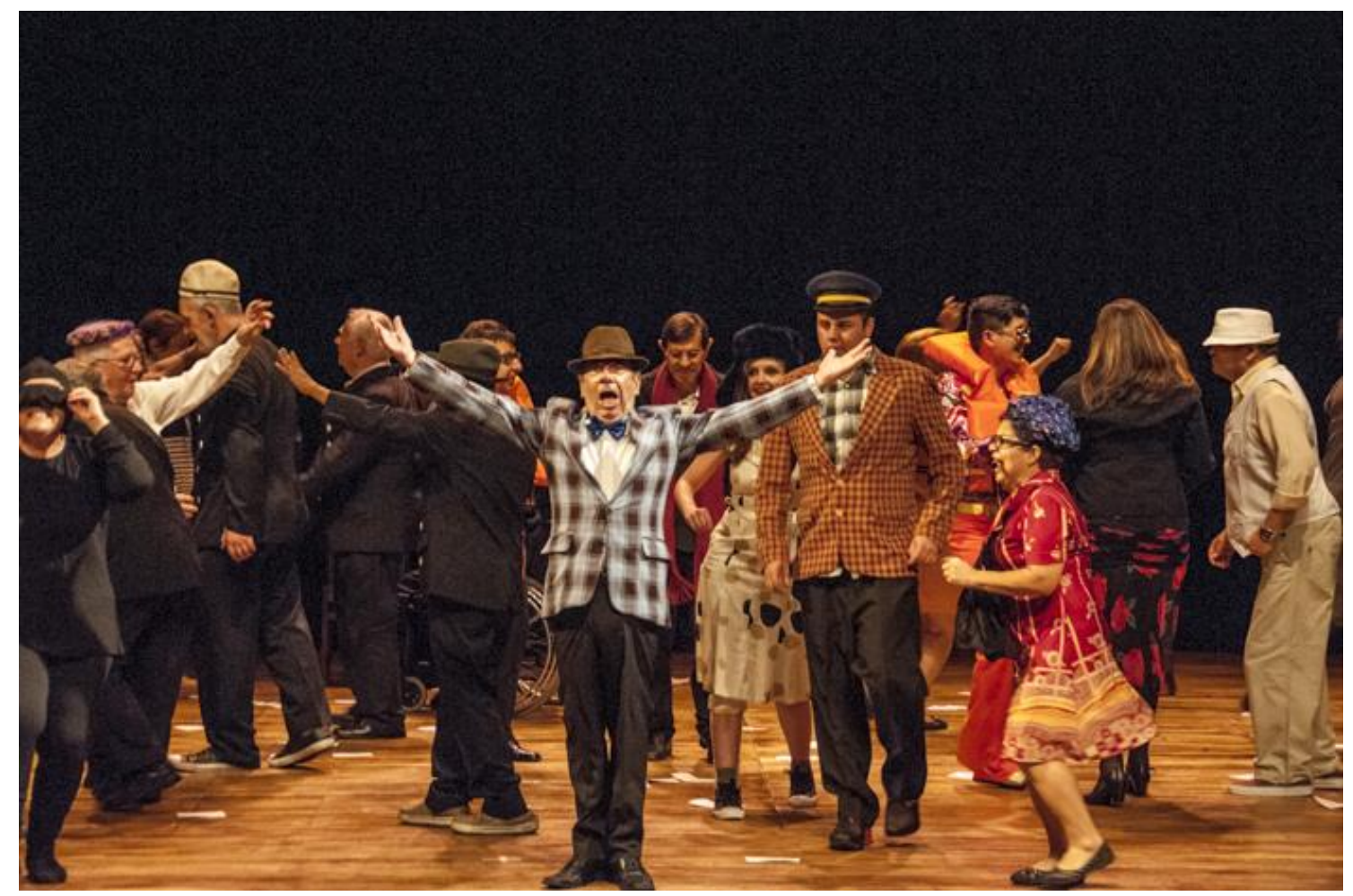

Pessoas que estão de frente na foto: José Nelson, Joaquim Falleiros, Jennifer Pessanha, Michael Aguiar e elenco da Ser em Cena. Foto: Luís Dávila/Vila Imagem

\footnotetext{
${ }^{36}$ Além do teatro, que é atividade principal, a ONG oferece outras oficinas: psicomotricidade (Celso Leme), fonoaudiologia (Fernanda Papaterra, Guilherme Zaramella e Ruth Soares Bicudo), danceability (Nicholas Wahba), psicologia e estimulação cognitiva (Fátima Monteiro) e musicalização (Wanderley Alves Júnior). Por causa da montagem do espetáculo, no segundo semestre as outras atividades podem ser um suporte de acordo com as necessidades da apresentação. A equipe também conta com Cláudia Niemeyer na coordenação geral, Michele René Ayed na comunicação, Liliana Wahba na vice-presidência, Elie Wahba como presidente e Cássia Navarro na secretaria. Até 2019, tínhamos também na equipe Cayo Eduardo e Evelyn Eduardo como assistente geral e produção, respectivamente.
} 
Atualmente, temos aproximadamente 75 participantes no teatro. $\mathrm{Na}$ área teatral, além de mim, tem Nicholas Wahba, que também é fundador da ONG e codiretor do espetáculo. Para montar uma encenação com quase oitenta pessoas no palco (muitas delas com dificuldade de locomoção), eu e parte da equipe nos desdobramos nas mais diferentes funções para conseguirmos criar, produzir e apresentar o espetáculo. Há bastante disponibilidade e flexibilidade para podermos lidar com os desafios e realizar uma montagem desse porte. Para mim, que achei que já estava acostumada com coletivos heterogêneos, foi uma experiência intensa o primeiro ano na ONG, ao lidar com uma estrutura desse tamanho, e a parceria da equipe - que acolheu minhas propostas, inventou outras e pensamos junto formas de realizá-las - foi essencial.

Imaginar as possibilidades coletivas de um elenco tão grande foi outro desafio. Dentro dessa estrutura, como posso preservar um lugar de criação estética para tantas pessoas? Por meio da diversidade de corpos e experiências, nosso percurso tem sido o de criar cenas coletivas, que ao mesmo tempo também fazem com que cada pessoa tenha seu "momento" de singularidade nessa gramática cênica. O percurso junto a ONG Ser em Cena tem sido importante na vivência de um processo no qual as particularidades de cada pessoa engendram a linguagem cênica, e na percepção de que esse espaço de criação é estético e existencial ao mesmo tempo.

Em 2016, criamos o espetáculo Do outro lado do oceano, a partir do universo náutico e das embarcações. De acordo com o texto que escrevi para o programa:

Do outro lado do oceano é sobre embarcações e suas rotas. Essas rotas são feitas de derivas, ancoragens, atracações e reboques, casa das máquinas e convés, proa e fundo do mar. Personagens de tempos diferentes se cruzam, se misturam e se sobrepõem nesse percurso, entre descobertas de novas constelações e criaturas marinhas raríssimas, um pássaro que pousa na escotilha, uma passagem pelo trópico de capricórnio, histórias de amor e cartas náuticas.

Às vezes, quando se perde o rumo, quando não há palavra que dê conta, temos que inventar novas línguas. Ou esboçar um gesto, uma dança, criar outros instrumentos de navegação.

Nossa encenação parte de histórias e situações vividas, ouvidas e inventadas que envolvem marinheiros, tripulantes, sereias, astrônomos e astrólogos, cozinheiros e lambaris. É uma viagem sobre o que nos move, sobre criação e sobre compartilhar com vocês quantas coisas podem acontecer a tantos nós por hora. 
O tema foi sugerido por Nicholas e Liliana Wahba, e sua abrangência permitiu que criássemos várias cenas a partir de situações agenciadas a partir desse universo. Em geral, criamos as cenas separadamente com cada turma, organizando-as em nosso roteiro dramatúrgico, e dois meses antes das apresentações fazemos alguns ensaios gerais com todo o elenco, alguns cuidadores e acompanhantes e parte da equipe, de modo que são quase cem pessoas nesses dias. No segundo semestre, tem sido possível contratar três assistentes para ajudar na logística, e também um colaborador na trilha sonora e sonoplastia, mas ainda assim nos surpreendemos a cada ano como conseguimos realizar essas apresentações com uma equipe reduzida. Do outro lado do oceano foi apresentado em 2016 e 2017 no teatro do Sesi e no Teatro Frei Caneca.

Em 2018, criamos o espetáculo Silêncios, moléculas, dinossauros, dessa vez a partir do universo das listas e dicionários. Tenho um interesse especial por esse tema, e o hábito vem de antes. Nas aulas na lavanderia relatadas no início deste capítulo, além do tema das partes do corpo, havia outra "disciplina", as partes do mundo. Invariavelmente, as aulas eram sobre um desses dois temas e consistiam de listas dos itens que eu conhecia ou inventava. Reproduzo aqui o texto que escrevi para o programa, no qual, além de descrever o porquê do tema, temos uma ideia das cenas:

\section{Silêncios, moléculas, dinossauros}

Uma lista pode ser uma tentativa de organizar o mundo, ou inventar outros.

Por exemplo, podemos começar com os animais vertebrados e os invertebrados.

Ou os que correm, voam ou rastejam.

As tardes esquecidas.

As coisas que fazem virar os olhos, os bens do Olimpo.

Os colapsos, o que coça e o que pinica.

Talvez os amores marítimos fiquem perto dos guarda-chuvas perdidos.

E assim por diante.

Nosso ponto de partida foram verbetes, listas, dicionários, enciclopédias, e outras ficções. Mas o que têm em comum microscópios, dinossauros, tipos de silêncio, palavras que doem, ou fantasmas?

Assim como nas histórias do livro As mil e uma noites, o nosso compêndio também tenta enganar a morte. E não é isso que, de uma forma ou de outra, estamos todos fazendo?

Bem-vindas e bem-vindos às nossas noites, aos nossos dias, aos nossos jeitos de inventar novos possíveis ${ }^{37}$.

\footnotetext{
${ }^{37}$ Programa do espetáculo Silêncios, moléculas, dinossauros. 2018 e 2019.
} 
E sobre os começos: para que os eventos relatados pudessem existir, outros antes aconteceram, que vão além da circunscrição familiar, geográfica e individual. Por quatro milhões de anos, uma série de encontros de criaturas das mais variadas formas, em tempos e lugares distintos, geraram ancestrais que sobreviveram e criaram conexões específicas para que estivéssemos aqui. Também somos feitos de minerais e temos em nosso corpo vestígios de anfíbios e de aves. Já vivemos em árvores e tivemos brônquios ${ }^{38}$.

Ou podemos considerar o nosso processo histórico, contado a partir da ficção "de descobrimento" que encobre a dominação violenta de um povo por outro. Esse processo gerou uma bisavó da qual só sei que gostava de circo e de baile, e o nome: Brasilina. Diferente dos outros avôs e avós vindos de Polônia, Itália e Portugal, que têm fotos e histórias que remontam a dois ou três séculos, de Brasilina, nascida aqui, não sei quase nada e nunca vi uma foto. Também ela é um começo de todo esse percurso.

Não são somente os coletivos, espaços e processos de criação que são heterogêneos. Retraçar um percurso imaginando uma heterogeneidade temporal nos faz poder conectar pontos distantes de um modo diferente do da linha do tempo, não submetidos a uma ideia de linearidade ou de progressão. $O$ que pode acontecer se imaginarmos um tempo que se abre para essas outras dimensões, históricas, biológicas, sociais, afetivas, constelando outras modalidades de existir e de criar?

\footnotetext{
${ }^{38}$ Este trecho final é inspirado no livro Breve historia de quase tudo, de Bill Bryson (São Paulo: Companhia das Letras, 2005) e em aula de Peter Pál Pelbart no curso Pensar é estar à escuta da vida: o abecedário pandêmico de Deleuze, ministrado em julho de 2020 no Atelier Paulista, São Paulo.
} 


\section{PARTE II - INVENTÓRIO}


Talvez estejamos muito condicionados a uma ideia de ser humano e a um tipo de existência. Se a gente desestabilizar esse padrão, talvez a nossa mente sofra uma espécie de ruptura, como se caíssemos num abismo. Quem disse que a gente não pode cair? Quem disse que a gente já não caiu?

(KRENAK, Ailton. Ideias para adiar o fim do mundo. São Paulo: Editora Companhia das Letras, 2019. Kindle, I.262.) 


\section{INTRODUÇÃO}

\section{Quantas Lauras existem?}

Quando Anselmo visitou o Instituto Butantã, disse que não tinha medo de escorpiões ou cobras, mas se assustou muito com os grilos. Caio sonha em voar, ser um monge e ser dono de uma emissora de televisão. Petra só quer ficar deitada no chão. Quantas Lauras existem? Um coração que vira banquete. Um bandido que vira quinta-feira. A dubladora muda. Pessoas foram proibidas de jogar capoeira no Parthenon por causa do terremoto na Grécia. Uma casa onde a cadeira, o bolo-noite, o amanhecer, o cozinheiro e a vizinha enciumada conversam. A viúva noiva. Rodrigo conta o sonho do guaxinim gigante que estava embaixo da árvore, ria para ele e ele virava um bebê.

Essas imagens vêm dos coletivos descritos no capítulo anterior: Algumas descrevem uma fiç̧ão; outras, um acontecimento. A sua convivência no mesmo parágrafo evidencia a sua coincidência: o quanto nossa realidade é feita de ficção; o quanto de real nossas ficções ancoram. O lado a lado das descrições mostra, em nossos processos criativos, a busca de operar por outras coordenadas que escapem de oposições como normalidade-loucura, ou realidade-ficção. Além disso, "estudando mais de perto os sentimentos, tornase cada vez mais claro que, no corpo, ficção e verdade são absolutamente reais. É a operação de tradução que anuncia e corporifica os limites e as zonas de indistinção"1. Ainda a partir dessas imagens (momentos dos nossos processos criativos), para pensar em possíveis traduções desses estados corporais e sentimentos, um aspecto essencial é procurar criar uma atmosfera na qual possamos nos abrir a diferentes lógicas,

[...] multiplicar as formas de conexão, de linguagens, de abordagens, de entendimento. Pluridimensionar o campo. Recusar a homogeneização sutil mas despótica em que incorremos às vezes, sem querer, nos dispositivos que montamos quando os subordinamos a um modelo único, ou a uma dimensão predominante ${ }^{2}$.

\footnotetext{
1 GREINER, Christine. O corpo em crise, novas pistas e o curto-circuito das representações. São Paulo: Annablume, 2010. p.88.

2 PELBART, Peter Pal. Um desejo de asas. In: A nau do Tempo Rei: sete ensaios sobre o tempo da loucura. Rio de Janeiro: Imago, 1993. p.23.
} 
Neste capítulo, a ênfase é na investigação dos processos de criação com coletivos heterogêneos: o que acontece na sala de ensaio, nos encontros e no dia a dia com os diferentes grupos; como alguns procedimentos da performance, do teatro, da dança e das artes visuais são apropriados e metabolizados por pessoas com os mais diversos corpos, experiências e condições psíquicas, físicas e sociais.

A ideia de coletivo muitas vezes é domesticada e achatada a um denominador comum: de produtividade, ou criação de um produto artístico. A convivência entre diferenças tão radicais nos incita a encontrar diferentes modos de ser e de fazer grupo.

Daí o proveito que poderíamos tirar da ideia de Félix Guattari, de que a heterogeneidade precisa ser produzida. Não basta reconhecer 0 direito às diferenças identitárias, com essa tolerância neoliberal tão em voga, mas caberia intensificar as diferenciações, incitá-las, criá-las, produzi-las ${ }^{3}$.

Permeada pela busca por uma produção de heterogeneidade que acolha e legitime as diferenças, este capítulo é a seção do performer, na qual são descritos os dispositivos ${ }^{4}$ de criação, as descobertas e os experimentos cênico-existenciais que realizamos, assim como as hesitações, fracassos, impasses e contradições que fizeram parte desses processos.

Uma palavra-chave para nossa investigação é a transversalidade: nos encontros, as possibilidades de criação são instauradas transversalmente, o que significa que surgem não de um ou de outro participante, mas pela interação entre eles. A palavra interação aqui acolhe os mais diferentes modos

\footnotetext{
${ }^{3}$ Ibidem, p.23.

4 Segundo Foucault, dispositivo é um conjunto heterogêneo "que engloba discursos, instituições, organizações arquitetônicas, decisões regulamentares, leis, medidas administrativas, enunciados científicos, proposições filosóficas, morais, filantrópicas. Em suma, o dito e o não dito são os elementos do dispositivo. O dispositivo é a rede que se pode tecer entre estes elementos" (FOUCAULT, Michael. Sobre a história da sexualidade. In: Microfísica do poder. Rio de Janeiro: Graal, 2000. p.244). Posteriormente, o filósofo Giorgio Agamben leva esse termo a um uso um pouco mais abrangente, que inclui também, entre os dispositivos, "a escritura, a literatura, a filosofia, a agricultura, o cigarro, a navegação, os computadores, os telefones celulares" (AGAMBEN, Giorgio. O que é o contemporâneo? e outros ensaios. Chapecó: Argos, 2009. p.41). Entretanto, esse termo ainda se refere à produção de um sujeito dessubjetivado. Com o tempo, essa noção foi sendo usada de maneira positivada, que é como eu vou usar na presente dissertação: um uso não repressivo ou de controle, mas que proporciona abertura e vitalidade. "Também inclui discurso, arquitetura, horários, regras, mas é para favorecer a emergência de alguma coisa, não para obstruir. É um uso positivo no sentido do que produz e não do que captura" (Peter Pál Pelbart, durante meu exame de qualificação).
} 
de estar junto: inclui um não fazer, fazer um desvio, ou mesmo uma recusa do que é proposto. Esses modos de grupalidade e de criação são formas de interação importantes a serem levadas em conta em nossa busca de se produzir uma heterogeneidade que intensifique as diferenciações.

\title{
Existir mais
}

Os coletivos que fazem parte da pesquisa são heterogêneos, não somente pela diversidade de pessoas, mas pelo modo com que abordamos essa diversidade, tentando produzir a diferença. Ou seja, buscamos criar uma heterogeneidade que não é composta somente de pessoas diferentes umas das outras, mas que elas também possam diferir de si mesmas. Explorar planos diversos não submetidos ao que chamamos identidade, personalidade ou personagem pode abrir outras possibilidades:

\begin{abstract}
Convém evitar uma utilização simplista e reificadora de categorias como o autismo e a dissociação para qualificar a estranheza esquizo; a perda do sentimento vital, para as depressões; a gliscroidia, para a epilepsia... Mais do que com alterações deficitárias globais e padrões de uma subjetividade normal, devemos lidar com as modalidades ao mesmo tempo plurais e singulares de uma autoalteridade. Eu é um outro, encarnado no cruzamento de componentes de enunciações parciais extravasando por todos os lados a identidade individuada ${ }^{5}$.
\end{abstract}

Procuramos, em nossos processos criativos, dar condições para o aparecimento, ou a criação, desses outros modos de existência. Essas outras formas são investigadas pelo filósofo David Lapoujade: "não mais se trata de ser isto ou aquilo, mas sim de conquistar tantas novas maneiras de ser como

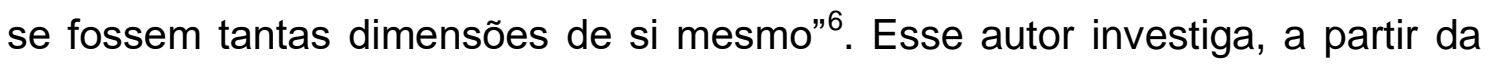
obra do filósofo Étienne Souriau, modos com que uma existência pode se tornar mais real e ganhar consistência, e como a legitimação desses diferentes modos é um gesto estético, mas também político, visto que nenhuma existência é menos autêntica do que outra.

É o que significa entrar no ponto de vista de uma maneira de existir, não apenas para ver por onde ela vê, mas para fazê-la existir mais, aumentar suas dimensões ou fazê-la existir de outra maneira. A arte e a filosofia têm isso em comum, que

\footnotetext{
${ }^{5}$ GUATTARI, Felix. Caosmose. São Paulo: Editora 34, 1992. p.105.

${ }^{6}$ LAPOUJADE, David. As existências mínimas. São Paulo: Ed. N-1, 2017. p.59.
} 
uma e outra visam colocar seres cuja existência se legitima por si mesma, através de uma espécie de demonstração luminosa de um direito à existência que se afirma e se confirma pelo brilho objetivo, pela extrema realidade do ser instaurado ${ }^{7}$.

Quando Lapoujade fala desses seres que reivindicam existir de outros modos, considera um "pluralismo existencial" ${ }^{8}$ que pode incluir "seres reais, imaginários, virtuais, invisíveis", tão diversificados como "um pôr do sol, uma fachada de um edifício, uma ilusão de ótica, uma dança de elétrons, um triangulo isósceles, uma ideia abstrata" ${ }^{10}$. Em nosso recorte, consideramos essas existências em dois sentidos: como criações artístico-estéticas e também dessas pessoas como criadoras. Cada uma dessas instâncias legitima, cria e produz a outra. Sem esquecer que com obras não queremos dizer um espetáculo ou produto artístico acabado, mas um movimento, um gesto, uma fala ou balbucio que podem ser criados nos encontros e ensaios.

Fotografia 8 - Curso de performance do Igual Diferente - MAM, 2018

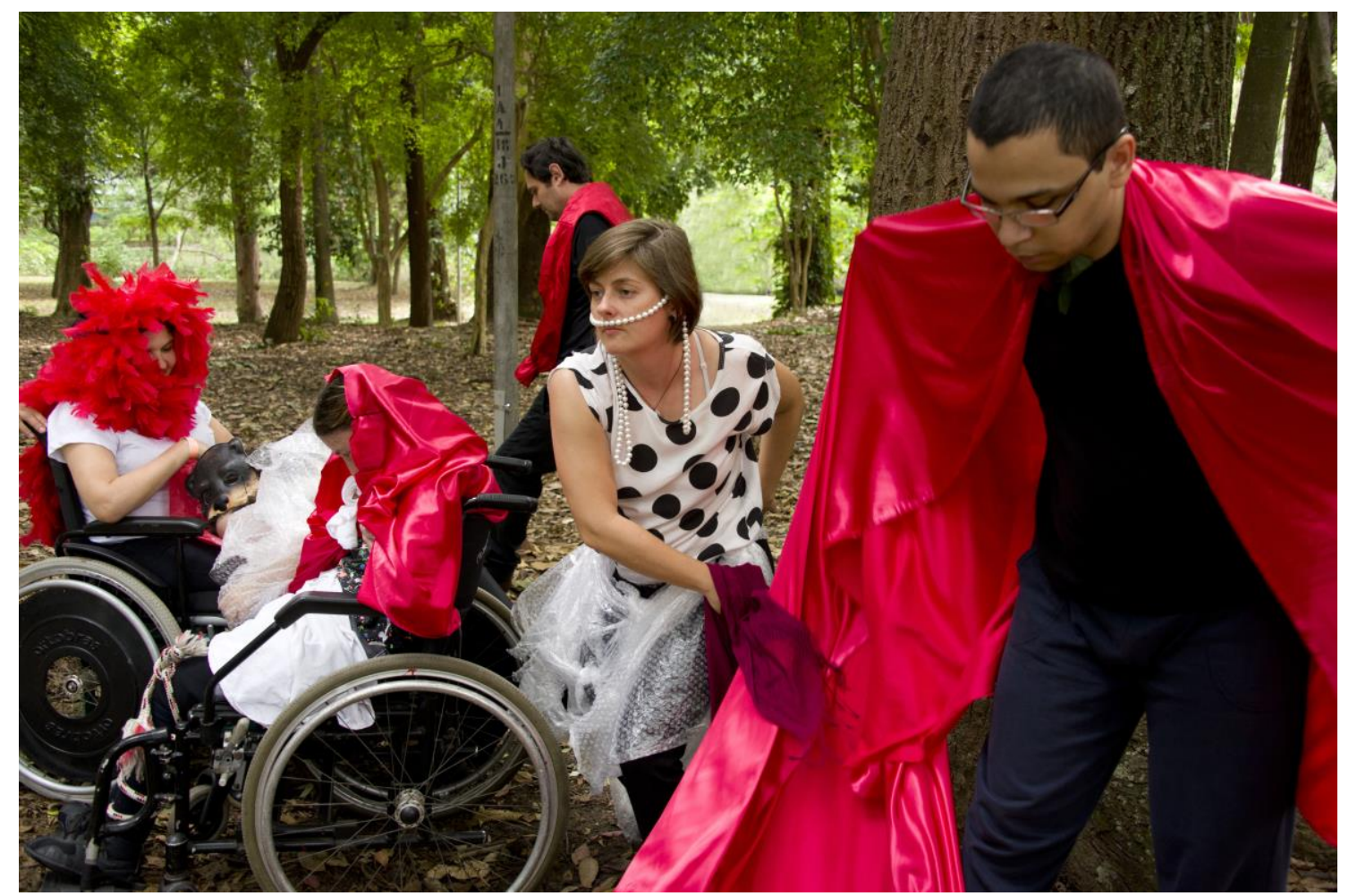

Fernanda Vaz, Alessandra Grimaldi, Armando Khoury, Agda Brigatto, Cleuby de Carvalho. Foto: Karina Bacci.

\footnotetext{
${ }^{7}$ Ibidem, p.90.

${ }^{8}$ PELBART, Peter Pál. Ensaios do assombro. São Paulo: N-1 Edições, 2019. p.226.

9 Ibidem, p.226.

${ }^{10}$ LAPOUJADE, 2017, p.27.
} 
Mais adiante, Lapoujade pergunta: "como pode um ser, no limite da inexistência, conquistar uma existência mais 'real', mais consistente? Com que gesto? Qual é a 'arte' que permite que as existências aumentem sua realidade?" ${ }^{11}$.

O diálogo com os estudos de Lapoujade é uma via de mão dupla: ilumina aspectos importantes de nossa investigação, assim como nosso dia a dia tenta responder a essas perguntas.

Optei por uma escrita ziguezagueante e hipertextual ao constelar as experiências neste capítulo: momentos que exemplificam modos diferentes de pensar o corpo, o erro, os enunciados, os coletivos, as diferenças de heterogeneidade em cada grupo em que participei, e como singularidades podem ser legitimadas em linguagem. Desse modo, após a leitura da Introdução, em que são dispostas algumas palavras-chave como transversalidade, inventório, improviso ou heterogeneidade, é possível escolher entre fazer o percurso ou passar de um tópico a outro a partir do desejo ou da curiosidade.

O que queremos, além e por meio da descrição dos processos, é mostrar como diferentes modos de existência podem nos mostrar possibilidades de viver e criar junto que escapem a formatações ou a um convívio uniformizador, "detectar, por debaixo desta homogeneização generalizada, os espaços-tempos distintos, percebê-los, diferenciá-los, cultiválos. O que significa também produzi-los"12.

\section{Inventório}

Registro em cadernos todos os encontros dos coletivos em que participo. Esse diário de bordo, além de conter o planejamento, a descrição e as reflexões sobre as atividades, também é uma espécie de banco de experiências com registros que podem ser transformados em cenas. Às vezes são palavras, pedaços de conversa, um jeito de se mover, um esboço ou gesto mínimo: por exemplo a dança dos dedos de Anderson, o jeito em que ele desce os dois braços longilíneos tremendo os dedos das mãos. Ou então

\footnotetext{
${ }^{11}$ Ibidem, p.41.

12 PELBART, O anjo de Swedenborg, In: A nau do Tempo Rei, p.83
} 
Aracy imitando um dinossauro, que cria uma figura interessante que não é mais ela, mas ainda não é dinossauro. Chamo o arquivo de Inventório.

Essa palavra vem de inventário, que é o contrário do inventar. No inventário, criamos uma lista em relação a uma instância organizadora maior: os animais de uma floresta, itens do almoxarifado, ativos e passivos de uma sociedade comercial. Ou então a listagem acontece a partir de uma morte, um desaparecimento, e precisamos nos haver com o que ficou. No caso da invenção, há o surgimento do que não havia antes.

Este capítulo faz os dois caminhos, rua de mão dupla: realiza um inventário - coleção de momentos e experiências - e, ao mesmo tempo, descreve como esses exemplos e estudos de caso nos ajudam a pensar na invenção de possibilidades estéticas e de modos de criar que antes não estavam lá. Além de algumas das imagens descritas no início deste capítulo, reproduzo a seguir um trecho do inventório do primeiro semestre de 2017 na Ser em Cena:

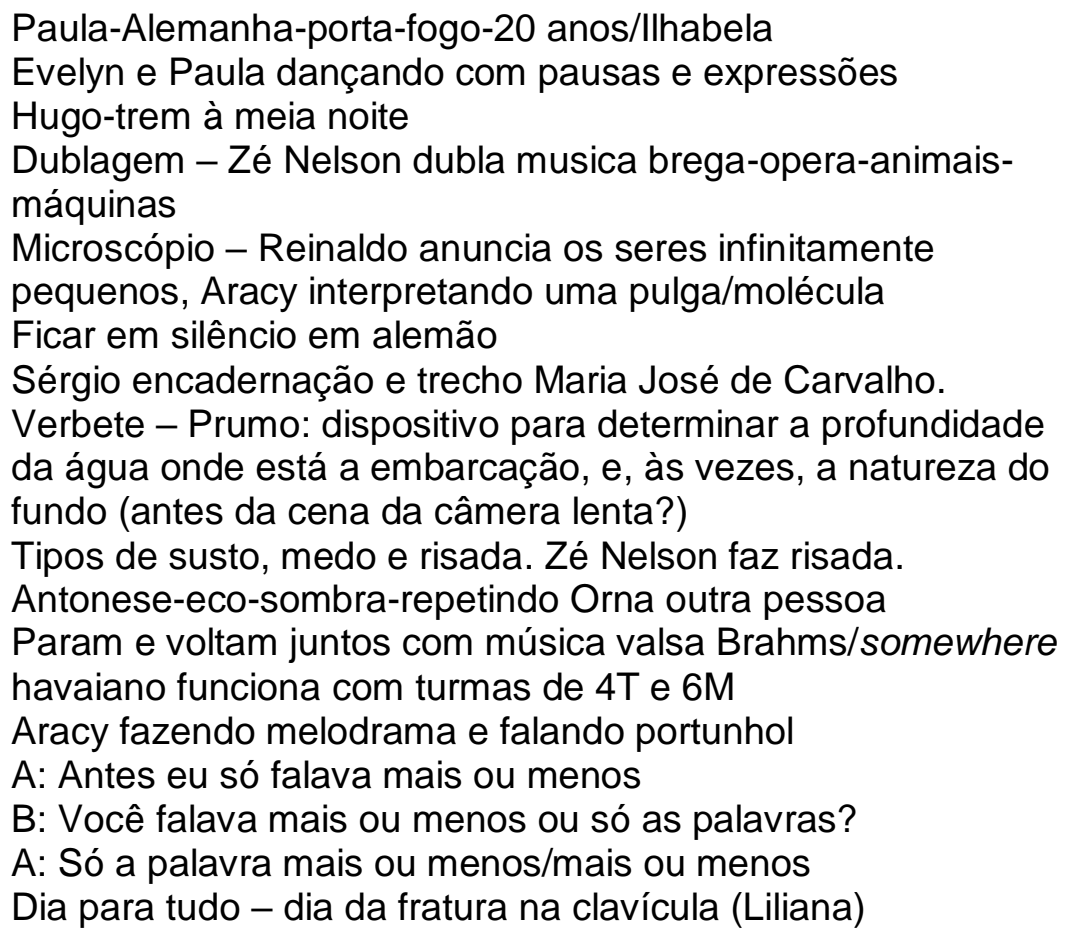

\section{Improvisar saídas, programar o acaso}

Uma parte das atividades realizadas com os coletivos é feita de improvisações nas quais as pessoas se reúnem em grupos e criam cenas a partir de um estímulo textual, sonoro, espacial, imagético, situacional etc. 
Geralmente são feitas combinações básicas entre cada grupo, a cena é então apresentada e os outros assistem.

Nos grupos analisados nesta dissertação, há o desejo e a criação de obras ou experimentos, sejam performances, espetáculos ou filmes. As improvisações acontecem com foco no processo, mas existe esse horizonte de expectativa. Nos casos do MAM e Cia. Ueinzz, é o processo e o tempo do coletivo que vão definir quando, como e em que formato esses produtos, ou recortes do processo criativo, serão realizados. No Gecep (Grupo de Estudos e Criação em Performance), houve dois convites pontuais que fizeram com que o grupo encontrasse uma forma para suas investigações. Na Ser em cena, o tema para o espetáculo é definido antes ou logo no início do processo, de modo que, durante o percurso de criação, as improvisações e os estímulos acontecem dentro do universo do tema agenciador. Para isso, há um trabalho de pesquisa temática, que realizo junto a Nicholas Wahba, no qual elaboramos uma grande "nuvem" de diversas associações relativas ao tema, que podem vir de pesquisas textuais, imagéticas e sonoras, e dessa constelação criamos os dispositivos e estímulos. Esse mapeamento é compartilhado com o elenco, que pode acrescentar sugestões de cenas e de textos ao processo.

No MAM, a dinâmica do encontro tem variações. Uma possibilidade é fazer uma primeira parte com exercícios que criem um pequeno vocabulário poético/corporal, por exemplo, experimentar ritmos diferentes ou densidades de movimento - algodão, água, ferro -, ou se mover a partir de partes do corpo, muitas vezes com músicas que podem ir de Radiohead a Arvo Part, passando por Cumbias, Penderecki e Bach. A partir dessa primeira parte, que também pode conter improvisações a partir desses estímulos, delimitamos uma área da plateia e um espaço cênico. Então, quem quiser pode ir para o espaço improvisar a partir de elementos experimentados na primeira parte. Geralmente indicamos que podem ir duas ou três pessoas, elas podem se relacionar e algo acontece, ou não. Falar podem ir é importante pois abre uma margem para a desobediência, ou desvio, ao que é proposto. Pode acontecer de irem dez pessoas, ou ficar uma pessoa durante bastante tempo, entrar outra e se relacionar, ou ficarem em um paralelismo. As indicações funcionam como estímulos, não imposição. 
Para que possam ser feitas improvisações e cenas com essa abertura à imprevisibilidade, uma série de acordos, explícitos e implícitos, precisam acontecer. Um exemplo desses acordos coletivos: Olivia, uma das participantes do MAM desde que começamos o curso de performance (2011), tem um modo bem direto de atravessar tempos, lugares e convenções, sociais ou teatrais, de acordo com o seu desejo. Com uma lógica própria e entendimento singular de algumas regras do laço social, sua presença não tem a mediação de polimento ou discrição. As datas e os acontecimentos são muitas vezes nomeados (como o 27 de maio de 2012 que foi o dia do não desculpo) e têm uma intensidade em sua vida que gera reações muito tempo depois. Ela pode me ligar para falar que já faz mais de sete mil dias desde o acidente de Chernobyl ou, nos encontros, perguntar de repente se eu a amava no dia 22 de abril de 2011, quantas Lauras existem, ou porque toda velha chamada Ava é chata.

A sua presença não passa despercebida, e nos convoca a repensar os modos de estar e criar coletivamente. Assim como qualquer pessoa, ela fica mais impactada por certos acontecimentos, que exigem de nós um processo de metabolização do acontecido. Em 2013, ela sempre trazia o tema do 11 de setembro nos encontros, nas perguntas ou improvisações. Em uma das cenas criadas nessa época, Tereza ${ }^{13}$ deitava de barriga para cima com as duas pernas levantadas. Elas eram as torres gêmeas. Nos encontros, Olivia fazia sempre um gesto com as mãos: socava com uma mão a outra mão espalmada na frente de outra pessoa, como uma simulação de estar matando aquela pessoa.

Ela fazia o gesto nas pernas de Tereza, que iam abaixando lentamente. Depois, ia matando os seus colegas de cena, um por um, que caiam com o seu golpe. Durante essa época, ela também trazia perguntas relacionadas ao tema: "Os terroristas mataram as pessoas? Morreu muita gente? Os terroristas eram maus? Porque eles fizeram isso?".

Se nos abrirmos a essas outras lógicas, em vez de domesticá-las segundo um pensamento normativo, percebemos que não é que seja estranho que ela continue se lembrando de Chernobyl ou de 11 de setembro tanto

\footnotetext{
${ }^{13}$ Tereza Rabelo, performer e psicanalista, aluna do Igual Diferente até 2014 e posteriormente perfomer do Grupo de Estudos e Criação em Performance.
} 
tempo depois, mas sua lembrança reincidente pode nos dizer algo sobre nossos esquecimentos.

Depois de fazer o gesto em seus colegas de cena, muitas vezes, Olivia o fazia na plateia e nos professores, que também caíam desmaiados (ou pelo menos tombavam a cabeça). Um dia estávamos fazendo a cena e ela fez o gesto no segurança (às vezes a porta do ateliê fica aberta e os seguranças do museu assistem um pouco da aula), que também simulou um minidesmaio. Essa reação evidencia, além de uma sensibilidade individual, um cuidado que transborda da cena e está relacionado a uma ação concreta de treinamentos com educadores, seguranças, profissionais da limpeza e outros funcionários para acolher a diversidade. Esses treinamentos incluem, por exemplo, aulas de libras (língua de sinais) para se comunicarem com as pessoas surdas ${ }^{14}$.

Podemos ver, nesse exemplo, em que um aquecimento pode se transformar em uma cena, ou um segurança participa de um improviso, como uma improvisação pode ter dimensões sociais e relacionais. (E o fato de eu não lembrar o nome do profissional da segurança também evidencia o quanto essa relação ainda pode melhorar.)

Além dos gestos da Olivia, outras pessoas podem não querer fazer uma cena ou fazer diferente do que é proposto, ou ainda entrar em uma cena de outro grupo, que tenta interagir cenicamente com a pessoa que entrou. É importante criar uma sustentação coletiva que comporte um tanto de desestabilização e de variação, mas sem que isso desmanche o encontro.

Por outro lado, mesmo acolhendo as variações, as turmas não somente desenvolvem um repertório do que foi experimentado no encontro, como também acumulam os materiais e indicações de vários encontros e ampliam esse repertório durante o curso. Por exemplo, no registro dos encontros de 2015, no dia 27 de maio, anotei que, quando pedi para as pessoas usarem os elementos agenciadores das improvisações anteriores - sombra; espelho distorcido; pausas; não começarem todos ao mesmo tempo; o final de uma

\footnotetext{
${ }^{14}$ De acordo com Daina Leyton, "Sensibilizações e capacitações da equipe do museu como um todo também foram necessárias. À medida que as pessoas da instituição, mesmo de áreas que não trabalhavam diretamente com o público, entendiam o alcance do trabalho desenvolvido e a capacidade de transformação por ele gerado, a apropriação e o envolvimento se fortaleciam, e - museu todo era contagiado pela riqueza da diversidade" (LEYTON, Daina Um museu de todos. In: Igual Diferente. São Paulo: Museu de Arte Moderna de São Paulo, 2015. p.15).
} 
música não quer dizer o final da cena; ondas de movimento que se agrupam e desagrupam -, elas lembraram, usaram todos os elementos com desenvoltura e ainda se lembraram de outros que nem eu lembrava. Para que isso pudesse acontecer, os corpos precisam estar disponíveis e à vontade.

Quando improvisamos, não são somente os temas ou os movimentos de cena que estamos abordando. De acordo com Christine Greiner, "testar a gênese de movimentos no ato, a partir de uma categorização instantânea do mundo ao redor com eficiência ${ }^{15}$, parece um grande desafio (para poucos)"16. Mais adiante, ela escreve que essa categorização "emerge da prática, não é dada" ${ }^{17}$.

Se pensarmos nessas diferentes instâncias ou agenciamentos envolvidos em uma improvisação, o próprio espaço criado para que possam ocorrer e, depois, o compartilhamento destas em uma apresentação (seja para as outras pessoas da turma, seja para um público de fora) propiciam que diferentes modos (estéticos e existenciais) sejam autorizados e legitimados, e as categorizações que passam a emergir dessas práticas possam colocar outros mundos em circulação. São cenas que, em suas lógicas particulares, como vimos nas imagens do início deste capítulo, experimentam ritmos, relações e intensidades variadas. $E$ essas intensidades convocam não somente a outro jeito de fazer ou entender o teatro. Ao lidar com esses diferentes graus de surpresa e imprevisibilidade, não é só a cena que improvisamos, mas também a vida, em suas variações.

\section{Diferentes tipos de heterogeneidade}

A liberdade temporal do MAM permite uma exploração mais processual da criatividade, experimentações e descobertas, e pode se abrir à impensadas lógicas de mundo e de criação. Na Ser em Cena, a exigência temporal e demanda por um produto final geram um processo que já nasce dentro de um universo específico, no qual a vertigem de criar com prazo, se por um lado intensifica a imersão, por outro estabelece uma moldura e potencializa a

\footnotetext{
${ }^{15}$ Vamos pensar aqui a palavra eficiência como o fato de se conseguir improvisar, não como algum critério de qualidade estética ou virtuosística dessa improvisação.

${ }^{16}$ GREINER, Corpo: pistas para estudos indisciplinares. São Paulo: Annablume, 2005. Kindle, I.1634.

${ }^{17}$ Ibidem.
} 
criação. A restrição de tema e de tempo geram uma amplitude de materiais dentro do universo temático.

O que a heterogeneidade entre diferentes coletivos nos diz sobre formas de criar e de estar junto? Além das características em relação ao processo criativo, como cada instituição ou grupo lida com as equipes, nos seus diferentes diapasões de vibração, de afetos e de dinâmicas? Como cada equipe acolhe e legitima diferentes modos de existência?

Jean Oury, com seus estudos sobre a relação entre loucura, arte e criação, pode nos ajudar a responder, ou conviver com essas perguntas. Oury foi psicanalista, fundador e diretor (junto com Felix Guattari) da clínica psiquiátrica de La Borde, na França, onde se colocava em prática uma abordagem singular da loucura e seus tratamentos, com mais horizontalidade entre os pacientes e a equipe terapêutica. Com sua experiência acerca do coletivo, das singularidades e da importância da heterogeneidade da equipe em uma instituição, ele traz novos elementos a nossas práticas.

Em suas obras, Oury ressalta alguns aspectos essenciais para que se tenha uma eficácia terapêutica nesses espaços: essas características se referem ao trato institucional com os psicóticos, mas podemos ampliar o seu sentido e observar como coincidem com alguns procedimentos da performance que utilizamos em nossos processos de criação. "O autor [Oury] reitera a importância da heterogeneidade em contraposição à formatação ${ }^{18 ”, ~}$ assim como "a abertura à surpresa, à permeabilidade e à diferença ${ }^{19 ", ~ e ~ a ̀ ~ c r i a c ̧ a ̃ o ~ d e ~}$ "espaços do dizer" ${ }^{20}$ que operam por uma "lógico-poética"21 que "traz algo do sentido, distinto da significação" e que permite aos insensatos os desvios do sentido sem que se percam ou sejam cercados pelas delimitações da significação ${ }^{22}$. Essas descrições reverberam com o universo da performance e de um teatro contemporâneo: mais ancorado em uma ideia de presença, que

\footnotetext{
18 BIALER, Marina. Ensinamentos dos esquizofrênicos para o tratamento institucional das psicoses. Estilos clin., São Paulo, v. 21, n. 3, p.657-670, dez. 2016. Disponível em $<$ http://pepsic.bvsalud.org/scielo.php?script=sci_arttext\&pid=S1415-

$71282016000300006 \&$ Ing=pt\&nrm=iso $>$. Acesso em: 3 jul. 2020.

${ }^{19}$ Ibidem.

${ }^{20}$ OURY, Jean. O coletivo. São Paulo: Hucitec, 2009. p.115.

${ }^{21}$ OURY apud BIALER, 2016.

${ }^{22}$ OURY, 2009. p.201.
} 
escapa à lógica representativa, e mais entrelaçado ao real do que à ficção, ao acontecimento do que ao enredo.

Oury inaugurou o que se chama de psiquiatria institucional, que defende que se deve tratar os doentes, mas também é preciso "tratar" da instituição. Para ele, a importância da heterogeneidade da equipe em instituições as torna mais vivas e se relaciona à criação de um aparelho coletivo que permita a circulação dos desejos de todas as pessoas que dele fazem parte.

\begin{abstract}
A constelação tem mais eficácia quanto mais ela é heterogênea; ela é "heterogênea" se as pessoas não se parecem. Por exemplo, se convocamos numa constelação dez psicólogos diplomados, é muito menos eficaz que um psicólogo mais uma faxineira, mais um cozinheiro, mais um jardineiro, mais um esquizofrênico, mais um médico chefe, mais um guaxinim. Há então muito mais possibilidades de surpresas, de trocas, de manifestações, de expressão ${ }^{23}$.
\end{abstract}

Novamente, é bom lembrar que a heterogeneidade não está garantida pela disposição de pessoas diferentes em um coletivo. Oury descreve como o simples ajuntamento de pessoas diferentes, principalmente em instituições, pode sofrer a ação da entropia e gerar uma acomodação, até se deteriorar e virar o que ele chama de "necrópole", sucumbindo às hierarquias, burocratizações e tecnocracias. Para ele, o coletivo funcionaria como uma máquina abstrata, um operador que poderia agenciar essas expressões e diferenças sem sucumbir a essa erosão. "Reunir pessoas não é simplesmente colocá-las umas ao lado das outras, mas sim colocá-las em situações dentro das quais elas possam exprimir-se"24.

Em que medida nos coletivos abordados nesta pesquisa podemos fomentar uma heterogeneidade capaz produzir diferenciações que possibilitem diferentes expressões?

No programa Igual Diferente, os cursos são acessíveis a todas as pessoas, e tem a duração de dez meses, o que permite que os participantes vivenciem a criação artística "não apenas em visitas pontuais, mas em cursos

\footnotetext{
23 Ibidem, p.76.

24 Ibidem, p.194.
} 
de longa duração; não apenas como espectadores, mas realizando pesquisas continuadas, desenvolvendo o seu percurso criador"25.

Fotografia 9 - Curso de performance do Igual Diferente - MAM, 2018

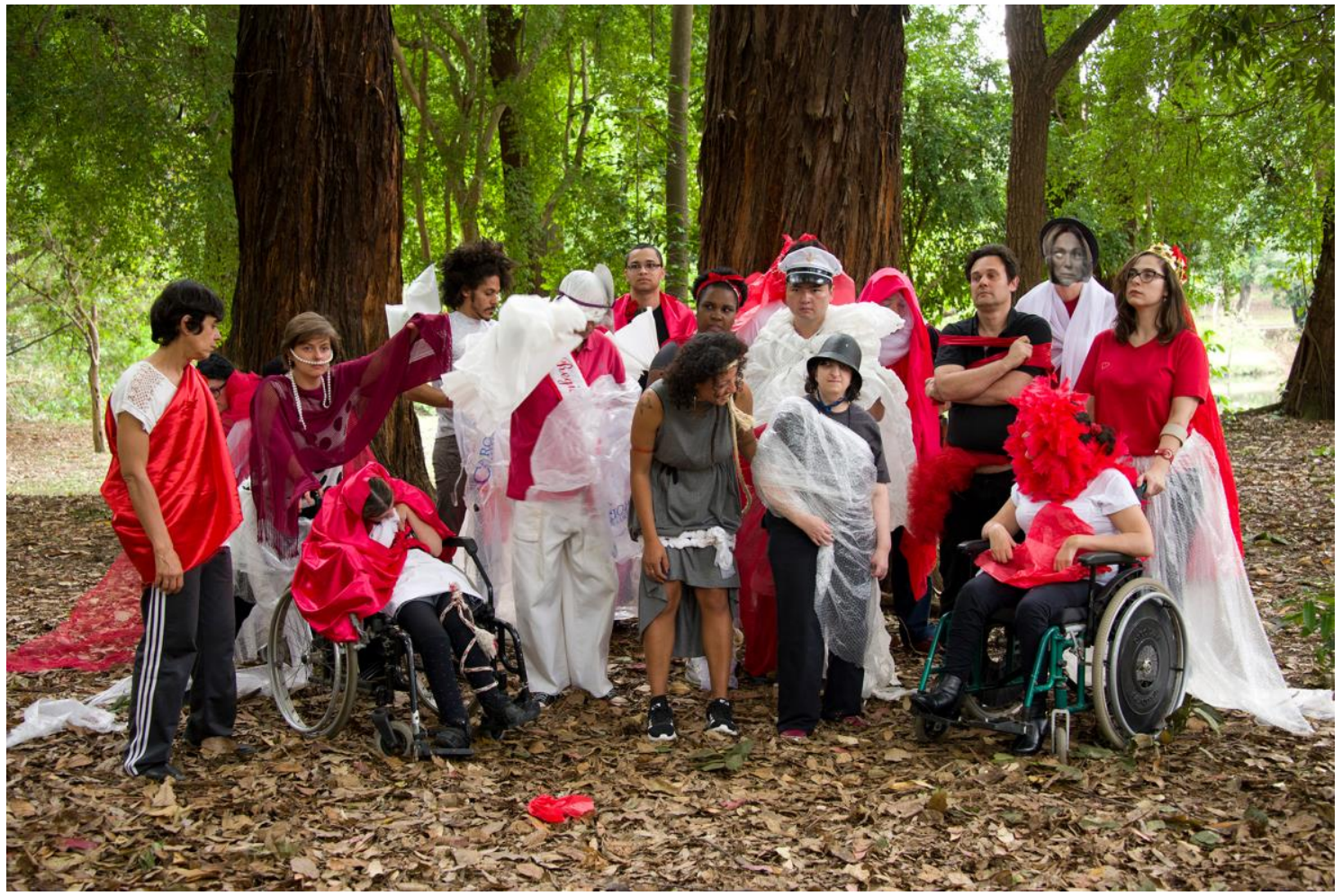

Da esquerda para direita, de cima para baixo: Cristina Márcia, Agda Brigatto, Leonardo Castilho, Júlio César, Cleuby de Carvalho, Jaque Paz, Carlos Massao, Armando Khoury, Fernanda Zardo, Alessandra Grimaldi, Erika Mota, Ana Cardelli, Fernanda Vaz. Foto: Karina Bacci.

A composição da turma do curso de performance é de uma heterogeneidade intensa de corpos, possibilidades expressivas, ritmos e experiências de vida. A inscrição nos cursos do programa Igual Diferente é aberta. Para que essa heterogeneidade possa acontecer, a equipe do educativo faz parcerias com instituições de saúde mental de São Paulo (como o Capes Butantã, da Zona Oeste, ou a Casa de Todos, da Zona Sul), de modo que há um diálogo entre diferentes pontos geográficos da cidade, assim como acolhimento de pessoas que de outa forma não saberiam da existência desses cursos. Além dessas pessoas e de outras que se inscrevem a partir do site do

${ }^{25}$ LEYTON, Asas para um desejo. In: Educação e acessibilidade: experiências do Museu de Arte Moderna de São Paulo. São Paulo: Museu de Arte Moderna de São Paulo, 2018. p.163. O itálico é do texto original e se refere ao curso que deu origem ao Programa Igual Diferente. 
museu, os educadores do MAM podem e também participam dos cursos como alunos.

Além do curso de performance (que ministro junto com o performer Leonardo Castilho, educador do MAM que começou como aluno frequentando os cursos e que é surdo), temos também um curso de escultura, ministrado pelos artistas Rogério Ratão (que é cego) e Victor Dantas; o curso Linguagens Gráficas (ministrado por Laura Teixeira); de fotografia, ministrado pela fotógrafa Karina Bacci; e o curso Corposinalizante, também ministrado por Leonardo e que é "aberto a jovens surdos e ouvintes". Neste último, são desenvolvidos "projetos culturais, documentários, performances e intervenções poéticas que dão visibilidade à identidade surda e à cultura dos jovens" ${ }^{26}$. Os cursos e a composição das turmas caminham em direção à constelação heterogênea que Oury nos fala e exemplificam o entrelaçamento estético, clínico e social que essa heterogeneidade pode ter.

A Ser em Cena atende aproximadamente 75 pessoas e procura dar prioridade a pessoas com afasia. Há algumas características que são comuns em várias pessoas, como a paralisia em um dos lados do corpo, o que especifica as possibilidades de estímulos corporais nos encontros. A aparente restrição, por outro lado, evidencia outras particularidades e nos faz ver que existem inúmeras variáveis de ritmo, fala, modos de se mover, densidades, humor e características de repertório corporal, confirmando o sentido da afirmação de que existem tantos tipos de afasia quanto de pessoas com $\operatorname{afasia}^{27}$.

Em outras palavras, o termo restrição traz um universo de débito. Abandonar essa visão e considerar os corpos que estão ali como eles são, ou como estão naquele momento, potencializa o repertório e o coletivo que temos. A mesma coisa ocorre com a fala: nos termos médicos, há um comprometimento da fala. Sem desconsiderar a dimensão importante do tratamento clínico e terapêutico das pessoas, é preciso que haja uma inversão

\footnotetext{
26 Descrição do curso no site do MAM. Disponível em: <https://mam.org.br/curso/corposinalizante/>. Acesso em: 8 jun. 2020.

27 Eu ouvi de Fernanda Papaterra, fonoaudióloga da ONG, que citou a frase como de autoria desconhecida.
} 
de valores no processo de criação teatral: o que era comprometimento ou transtorno de linguagem, passa a ser a particularidade de um léxico próprio. A partir dessa dimensão é possível ver e experimentar variados modos de criar linguagens, justamente, por meio das particularidades de cada um e cada uma.

Fotografia 10 - Silêncios, moléculas, dinossauros - Ser em Cena, 2018

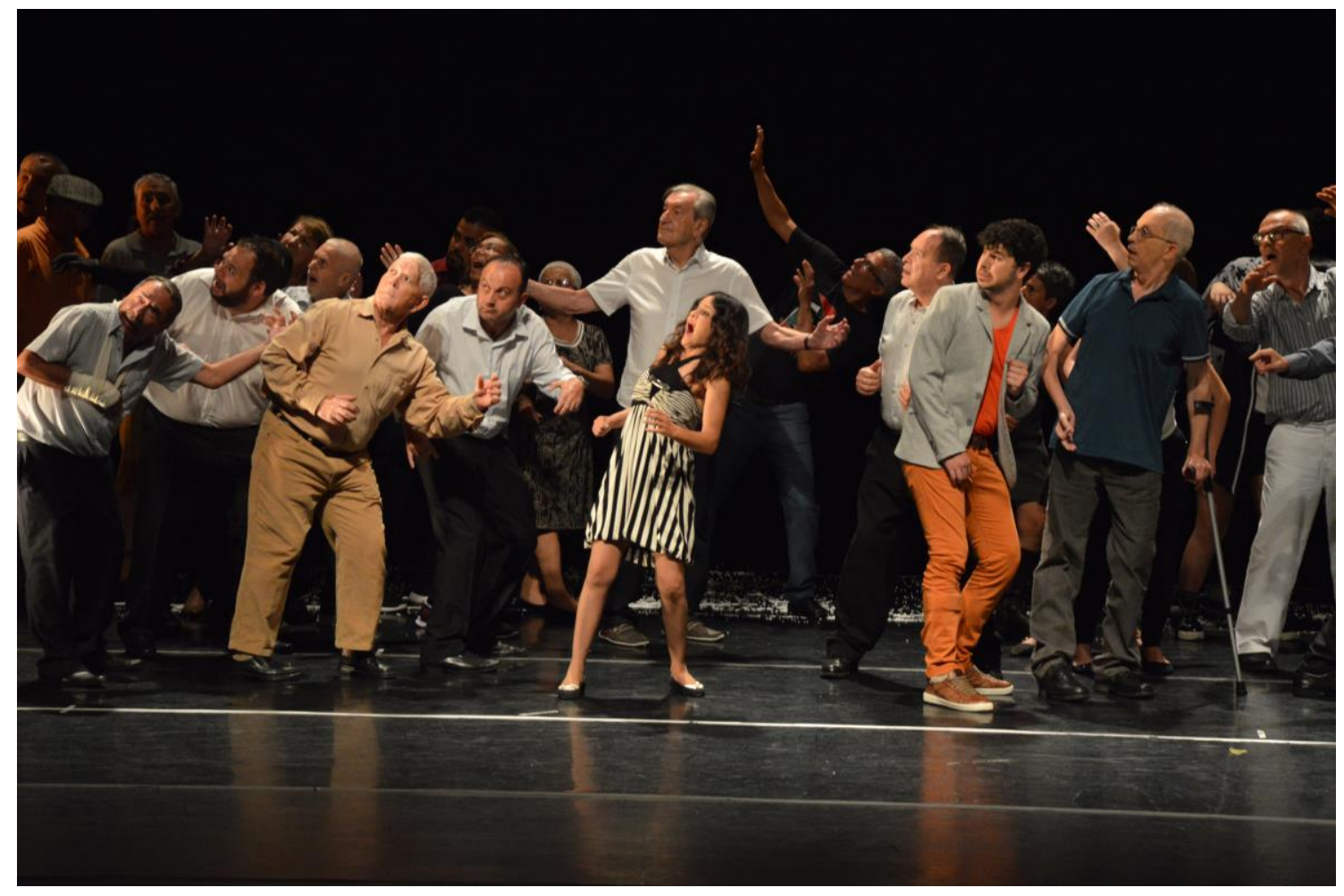

Elenco da Ser em Cena. Foto: Fábio Barrocal

Essa heterogeneidade cênica e existencial permite que as pessoas possam habitar lugares menos estigmatizados. O que vai definir um coletivo, portanto, não são as categorias totalizantes, como a afasia, mas como lidamos com as pessoas, como fomentamos as diferenciações. Nas palavras de Oury: como "colocar em prática sistemas coletivos e, ao mesmo tempo, preservar a dimensão de singularidade de cada um"28?

Na Ser em Cena, havia a criação de um espetáculo diferente a cada ano, e desde 2016 temos criado um espetáculo diferente a cada dois anos. Essa periodicidade permitiu um maior aprofundamento nas criações, no cuidado na composição do espetáculo e na apropriação e metabolização do processo como um todo. Acredito que isso fez crescer muito a qualidade do

${ }^{28}$ OURY, 2009. p.194. 
processo e do espetáculo, não somente na qualidade artística, mas principalmente na qualidade do tempo de criação, de poder observar, escutar, entender o ritmo e as particularidades de cada pessoa.

Cada processo tem suas particularidades, mas tanto na Ser em Cena, quanto no MAM, ou na Cia. Ueinzz, trata-se de coletivos que conseguem instaurar uma atmosfera propícia à investigação criativa, a um estado de abertura e de curiosidade para que essa investigação aconteça. Jean Oury pergunta em determinado momento: "Como podemos conseguir passar do grupo, que é algo que existe, ao que é um Coletivo?" ${ }^{29}$.

O que precisamos colocar em prática para que exista um Coletivo (que como vimos é diferente de juntar pessoas, mas encontrar um lugar que permita sua expressão) tem relação com a criação dessa atmosfera. É importante dizer que não se trata de uma busca por obediência, uníssono ou algum cerceamento do comportamento, mas da criação de um ambiente mínimo de estabilização para que a desestabilização possa acontecer. Explico: para que a criação surja, é preciso uma abertura à vulnerabilidade. Essa abertura está relacionada com uma certa desestabilização (das formas conhecidas, para que surjam outras). E para que essa desestabilização, abertura ou vulnerabilidade aconteçam, é preciso um tanto de estabilização: no sentido de espaço, tempo e estrutura.

Em outras palavras, mesmo dentro da heterogeneidade de diferenças entre os coletivos, podemos detectar um mínimo denominador comum que garanta alguma estrutura que torne possível cultivar uma implicação das pessoas envolvidas, com vínculo, senso de pertencimento e libido coletiva. Esse senso de pertencimento poderá então criar um chão para que se possa "perder o chão". Para poder gerar essa abertura, é preciso proteção: da equipe, da arquitetura, do tempo do encontro, da estrutura (institucional se for o caso). Esses elementos vão dar condições para que se tenha uma atmosfera segura que comporte as indeterminações dos encontros.

\footnotetext{
${ }^{29}$ Ibidem, p.278.
} 


\section{INVENTAR CORPOS}

Os corpos podem ser pesados. Luminosos, inacabados, suspirantes, descontrolados, lentos, rápidos, úmidos, desencaixados, solitários, amontoados, farfalhantes, excêntricos, vivos. Feitos de plumas pedras areia desencaixes jantares vísceras ideias séculos carpas espantos dúvidas silêncios. Como seus funcionamentos e desfuncionamentos podem reinventar gramáticas, velocidades, lógicas?

Christine Greiner, em seus estudos das transformações que as teorias do corpo $^{30}$ passaram ao longo do tempo, descreve-nos um primeiro momento em que, nas diferentes nomeações sobre o corpo, há uma necessidade comum de "estabilizar algo em torno de um objeto para que este represente o que resiste ao que poderia ser desfeito - a solidez como espécie de solidariedade entre seus componentes, a coerência, a coesão e a figurabilidade [... $]^{31}$.

Mais adiante, a autora descreve como Derrida imaginou "o que seria um novo corpo: anarquista, não orgânico, acefálico e vital. Começava uma mudança radical cujo foco cognitivo estaria sempre na fissura, nas fendas, nos entremeios e não nas partes organizadas de um todo monolítico"32. Essa mudança de abordagens do corpo não é somente descritiva, ou teórica:

[...] as representações do corpo fragmentado têm implicações sociais, psicológicas e metafísicas que tocam em temas cruciais da humanidade como a perda da inteireza, [e a] desintegração da permanência, [...], não apenas a partir de experiências estéticas, mas de condições de existência política $^{33}$.

A partir dessa abordagem anarquista de corpo, não submetida a uma ideia de funcionamento, vamos ver alguns exemplos de corpos: concretos, vibráteis, em partes, sem partes, particulares, desviantes. Como seus vários

\footnotetext{
${ }^{30}$ Em sua abordagem, ela nos mostra como essas teorias do corpo não são somente abordagens intelectuais separadas da prática, mas moldam e são moldadas reciprocamente pelas possibilidades de existência e de ação do corpo de cada época.

${ }^{31}$ GREINER, 2005, Kindle I.139.

${ }^{32}$ Ibidem, Kindle I.245.

${ }^{33}$ Ibidem, Kindle I.205.
} 
modos de existir criam jeitos múltiplos de pensar e reinventar o corpo, e como esses jeitos inventam cenas e mundos?

\section{Habitar um corpo}

Aníbal Quijano nos alerta para a importância de se "libertar o conceito de 'corpo' das implicações mistificadoras do antigo 'dualismo' eurocêntrico, especialmente judaico-cristão (alma-corpo, psique-corpo, etc.)"34.

Libertar o conceito quer dizer libertar o próprio corpo, pois, como vimos com Christine Greiner, conceitos não são percepções do intelecto separadas do corpo, mas são nosso jeito de estar e agir, em uma relação mútua que se alimenta reciprocamente, e "se mudamos as metáforas usadas em nossos processos, muda também o entendimento ontológico do corpo e suas possibilidades de experimentação" 35 .

Imagine um corpo estranho. Esse corpo incompreensível, vigiado, espiado e nu. Esse corpo - por exemplo, o do afásico ou do psicótico - tem suas gramáticas particulares. Podemos pensar um corpo que funciona por partes, que não funciona. Ou ainda, antes, nos perguntamos o que significa funcionar. É urgente repensar a terminologia. Talvez as palavras é que não sirvam para descrever o corpo. Que funciona de um jeito diferente da máquina, do relógio, do $\mathrm{DSM}^{36}$ (Manual do diagnóstico de doenças mentais), do teste Rorschach ou de tudo o que é diagnosticado, esquadrinhado, simétrico.

Dessa assimetria podem surgir outros foras, e para isso é preciso ter um corpo, estar vivo, respirar, mover-se. Cada corpo cria uma gramática própria. Alguns corpos particulares são talvez menos discretos que os outros. Nessa medida, eles apenas sublinham a dificuldade de se pensar o corpo. Do afásico, do psicótico, do não afásico, e do não psicótico. E mais: qual corpo que não é estranho?

\footnotetext{
${ }^{34}$ QUIJANO, Aníbal, Colonialidade do poder e classificação social. In SANTOS, Boaventura de Sousa; PAULA, Meneses Maria. Epistemologias do sul. Coimbra: Cortez Editora, 2014. p.105.

${ }_{35}$ GREINER, 2005, Kindle I.1785.

${ }^{36}$ Diagnostic and Statistical Manual of Mental Disorders.
} 


\section{Outros de si}

Em todos os coletivos deste estudo há alguns procedimentos que usamos com bastante frequência. Metabolizado de aprendizados da dança, teatro e performance ${ }^{37}$, é um dispositivo de criação de cenas e, antes disso, de criação de outros de si. Esses outros não são mais a pessoa, mas também não obedecem ao fechamento de uma personagem. No capítulo seguinte, vamos nos deter mais no conceito e na inserção desses outros de si no espetáculo. Aqui interessa ver como surgem essas figuras, como um corpo pode se transformar em outro a partir de suas partes, ou de diferentes equilíbrios.

Fotografia 11 - Perfomance Oito léguas para Fibo - Igual Diferente - Mostra Museu Dançante - MAM, 2014

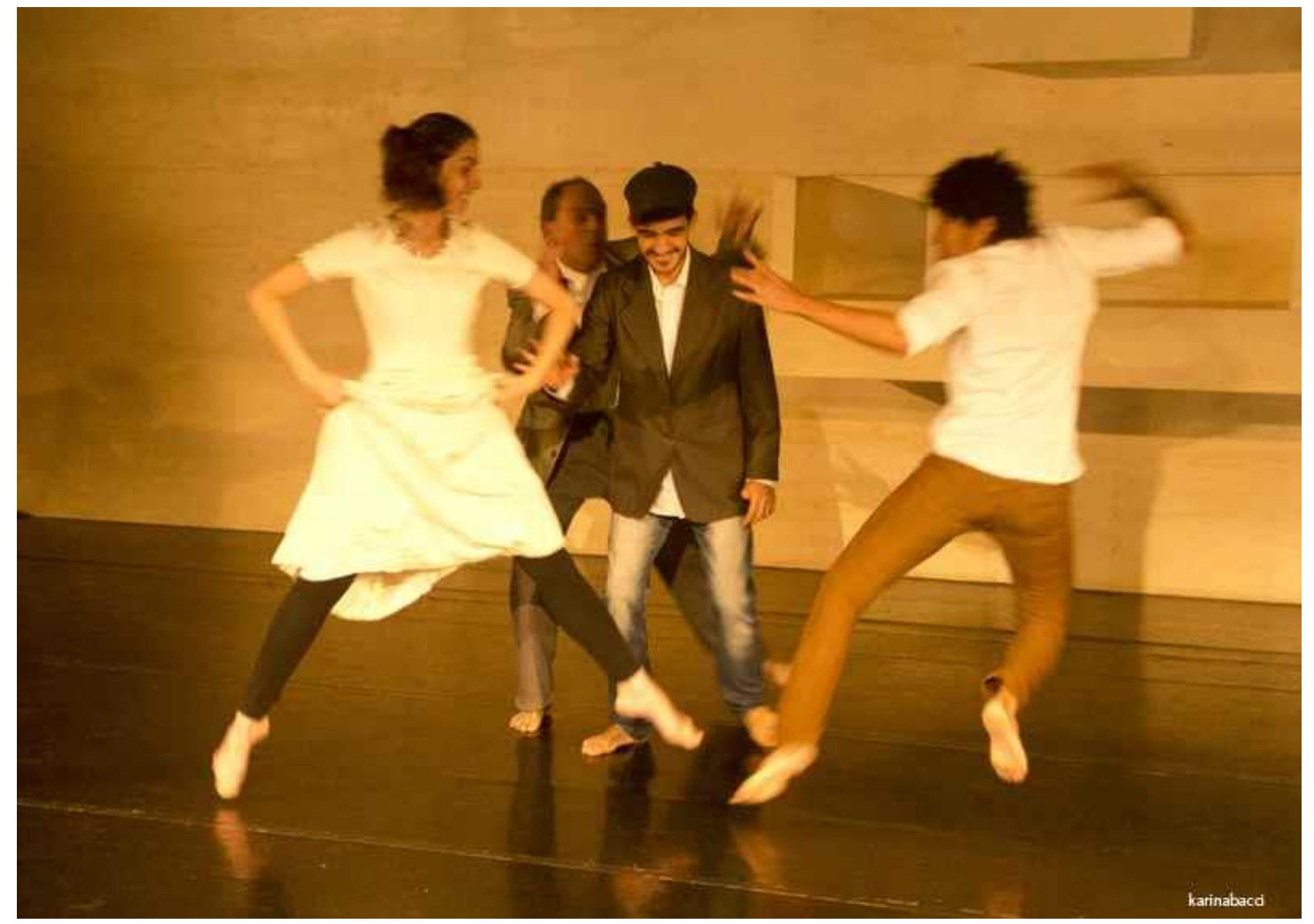

Tereza Rabelo, Paulo Dersu, Pedro Machado, Leonardo Castilho. Foto: Karina Bacci.

Esse procedimento tem dois momentos, que podem existir também separadamente. No primeiro, experimentamos deslocamentos, pausas e movimentos a partir de estímulos que desestabilizam a forma conhecida e

${ }^{37}$ Cristiane Paoli-Quito, Renato Cohen, Mauricio Paroni, Andreia Yonashiro são alguns artistas com quem tive experiências importantes nas quais pude aprender a criar outros de si por meio do corpo. 
habitual do corpo. Podem ser feitas variações de acordo com as características e desejos do coletivo; a seguir descrevo algumas possibilidades.

Uma primeira possibilidade é enunciar uma parte do corpo e as pessoas se movem a partir daquela parte. $O$ corpo inteiro participa do movimento, mas é a parte que conduz. Depois de um tempo, enuncio outra parte. Depois indico que cada um escolhe a parte que quiser, e pode mudar, mas não com tanta frequência; é bom investigar um tempo cada parte antes de mudar. Outras possibilidades de início: se mover a partir das molas/articulações do corpo (joelhos, pulsos, cotovelos); imaginar e se mover a partir de um corpo feito de água, algodão, lama, vento, ar etc.; diferentes animais que aos poucos vão se humanizando (pode-se brincar com porcentagens aqui); desequilíbrios ou diferentes equilíbrios corporais; utilização de tecidos, plásticos, objetos como extensões do corpo; entre outros. Pode também ser simplesmente a indicação para se deslocarem de um jeito diferente do habitual.

Em um segundo momento, a partir dessas investigações, peço para, aos poucos, escolherem uma dessas configurações corporais, ou deixarem as movimentações diferentes configurarem esse outro corpo que se move pelo espaço de um modo bem diferente do seu. Esse outro corpo também pode ser chamado de figura, persona, ou quem.

A indicação das partes do corpo como estímulos iniciais e o termo quem, um "esboço de personagem" ${ }^{38}$, ou uma base para "múltiplos personagens construídos e revelados pelo corpo e suas imagens no espaço" ${ }^{39}$ vêm de aprendizados em cursos com Cristiane Paoli Quito. Nos encontros, Quito nos incitava a descobrir variações: como esse quem se desloca pelo espaço? Como para? Como acelera ou desacelera? Como se relaciona com o que está em volta? Também experimentávamos relações: fazíamos uma grande roda, como na capoeira, e dois quems se levantavam e interagiam no meio da roda, e depois voltavam aos seus lugares. Outra indicação que ela dava era a de entrar e sair desse quem imediatamente. Assim, depois de longas explorações e deslocamentos pelo espaço em que conseguíamos criar um quem, ela

\footnotetext{
${ }^{38}$ VIEIRA, Cristiane Paoli. Movimento-imagem-ideia - o percurso de uma prática. São Paulo, 2016. Tese (Doutorado) - Universidade de São Paulo. p.89.

${ }^{39}$ Ibidem, p.72.
} 
simplesmente falava para desmancharmos aquela composição. Após alguns segundos, pedia para voltarmos a composição corporal do quem, também instantaneamente. Essa indicação é muito libertadora, pois desmancha uma crença de que é preciso um longo esforço para se entrar ou sair de um certo estado e mostra que existem vários caminhos possíveis. Acredito que isso dá uma margem de manobra cênica e existencial importante em coletivos heterogêneos (acredito que em todos os coletivos, mas ainda com algumas pessoas que tem um atravessamento mais forte entre real e ficção, essa indicação é muito útil).

Então, em nossos procedimentos, depois de um tempo explorando esses outros de si, cada pessoa pode se apresentar para toda a turma. Essa apresentação pode ser feita individualmente, em duplas, trios ou por meio de uma caminhada em linha reta em que se atravessa o espaço cênico paralelamente à plateia, ou vindo do fundo.

A partir disso, pode-se experimentar algumas variações:

- Encontros em duplas, relação no espaço cênico ou no meio de uma roda grande (pode acontecer de não haver relação e ficarem duas improvisações paralelas).

- Juntar duas duplas e elaborar uma cena: começa com cada dupla retomando a relação do exercício anterior. Depois podem interagir todos. Cada pessoa usar pelo menos uma pausa. Escolher até dois lugares onde a cena acontece (mesmo que não fique claro para o público).

- Apresentação de quems com aplauso, e pessoa desmancha o quem durante o aplauso (uma de cada vez).

- Delimitação de um espaço cênico, e as pessoas podem entrar e sair nesse espaço, mas quando entram estão com o corpo diferente.

- Alguém entra no espaço cênico, algo acontece e esse alguém sai de outro jeito (esse também pode ser um jeito mais instantâneo de criar um outro de si).

- Todas ao mesmo tempo, uma do lado da outra, atravessando o espaço.

Essa última possibilidade (uma pessoa ao lado da outra), assim como os estímulos iniciais de desequilíbrio, vieram da experiência com Renato Cohen e se chamava travessia. A partir do desequilíbrio corporal, atravessávamos o 
espaço em câmera lenta, com todas as pessoas de início juntas uma ao lado da outra, e fazíamos esse deslocamento com um equilíbrio diferente do habitual. Ele colocava músicas como Sonic Youth ou rituais balineses, e tínhamos que atravessar o espaço em um determinado número de minutos. Depois poderíamos repetir tentando reproduzir tudo o que aconteceu com o dobro do tempo de duração. Durante a travessia, íamos experimentando através dos desequilíbrios, da lentidão e da música - instaurar uma persona, ou outro de nós. Ao longo do tempo fui experimentando variações para esse procedimento, incluindo uma velocidade rápida e um enunciado em que a transformação é imediata, assim como também já experimentei travessias de quems em câmera lenta, metabolizando e inventando variações para esses procedimentos. É interessante notar que pode ser feito de uma maneira também superficial e ainda assim criar figuras extraordinárias.

Um aspecto importante: em nossos coletivos, muitas vezes, as indicações são ignoradas e as pessoas ficam mudando de partes (ou de elementos) sem parar, escolhendo duas ou mais ao mesmo tempo; podem também fazer aparentemente outra coisa ou, então, mudanças praticamente imperceptíveis. Esses casos não são erros, ou fracassos, já que o propósito é incitar as pessoas a serem outras. O quanto essas outridades são perceptíveis ou diferentes da proposta é subjetivo e está relacionado ao quanto acolhemos de desestabilização nesses coletivos, o quanto nos abrimos para o impensado.

Acredito que essa diferença é importante, pois, às vezes, mesmo sem estarem fazendo o que eu esperava, as pessoas estão implicadas do modo delas. Desenvolver um olhar e uma escuta para entendermos isso faz com que eu trabalhe o meu horizonte de expectativas de maneira que ele seja menos formatado e mais aberto ao que surge. Isso não quer dizer que vale qualquer coisa, mas os parâmetros do que "vale" e do deslocamento possível de cada pessoa vão ser dados de acordo com cada pessoa, cada coletivo e cada exercício, e não estabelecidos a priori.

Gosto de propor a criação dessas figuras, quems ou personas ${ }^{40}$ pela sua potência estética e existencial; liberta as pessoas para serem diferentes, e isso desestigmatiza os seus corpos, mesmo que sejam elas mesmas achando que

\footnotetext{
${ }^{40}$ As diferenças entre esses termos são descritas no Capítulo 3.
} 
estão diferentes: isso já não seria uma diferença? E faz também nosso olhar ficar mais desimpregnado.

Fotografia 12 - Curso de performance do Igual Diferente - MAM, 2018

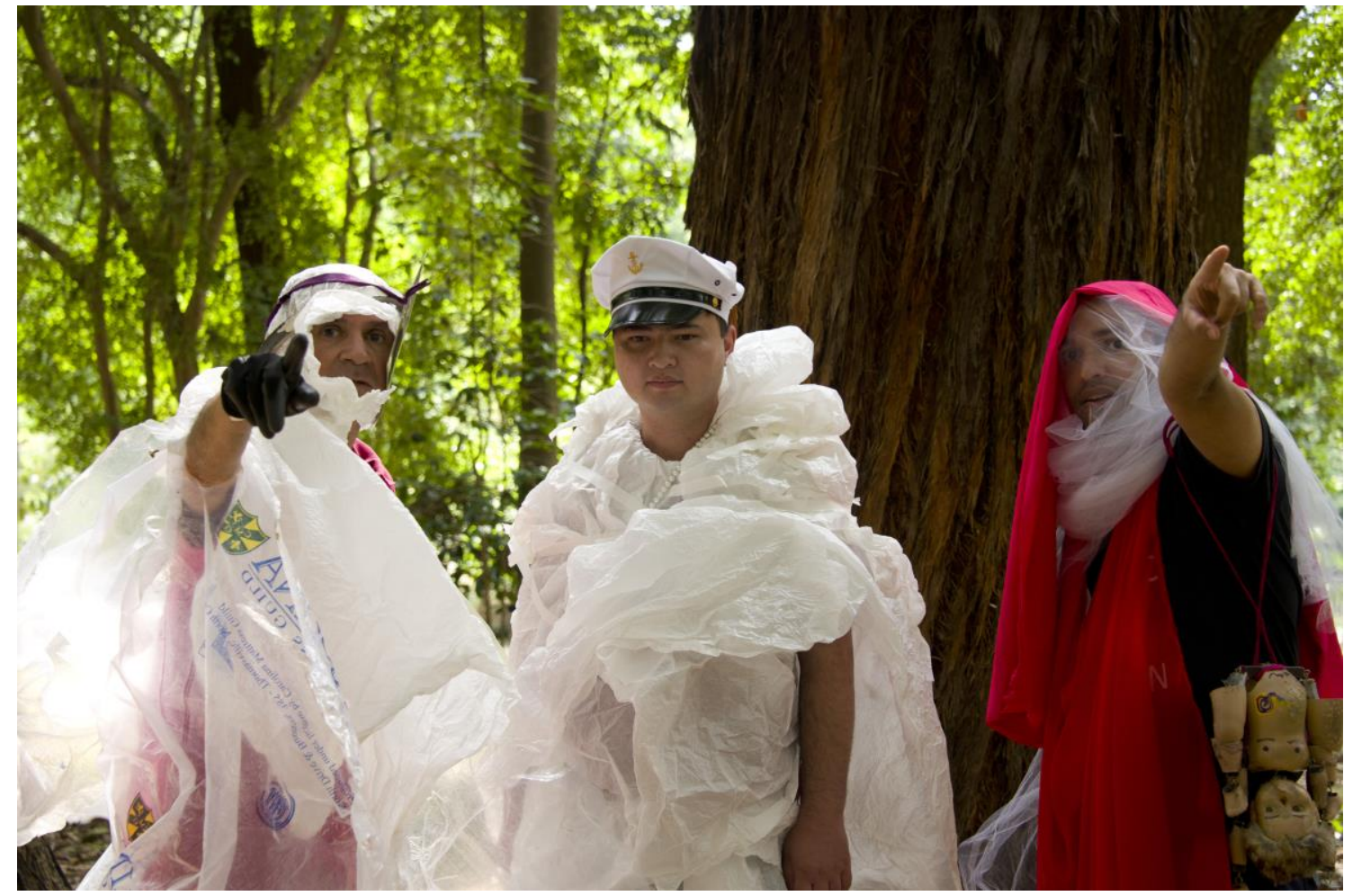

Paulo Dersu, Carlos Massao e Cleuby de Carvalho. Foto: Karina Bacci

\section{Ajustes}

Carmelita dança maravilhosamente e gosta de falar em uma língua própria que não sou fluente. Em um dos encontros, numa cena que estávamos ensaiando, experimentávamos uma dança em que só os braços e as mãos se mexiam. Carmelita não conseguia ficar sem mexer o corpo, eu fiquei um tempo do lado dela explicando que era só o braço e a mão, não adiantou; mostrei o meu braço e fiz para ela ver, não adiantou. Coloquei meu corpo colado no dela e fizemos juntas. A partir daí ela assimilou e manteve todas as vezes que repetimos a cena. Ela entendeu pelo corpo, assim como eu consegui explicar desse modo ${ }^{41}$.

\footnotetext{
41 "Há portanto uma ligação fundamental entre o pensamento, o espaço e a senciência cinética da vida. (...) Sheets-Johnstone considera fundamental observar "novos modos de pensar". Isso se dá pelo toque e pela experiência do corpo cinético-tátil, ou seja, é através do movimento, que se distinguem coisas importantes como saber que se está andando na areia ou num chão de pedra, o toque da mão na boca que faz um som de "m" ou um som de "p" e assim por
} 


\section{Distração}

Assim como há fluidez entre aquecimento e criação de cenas, também o que acontece antes do encontro, nos intervalos ou depois das nossas atividades pode mudar o plano inicial e gerar materiais cênicos.

Precisamos ficar com uma espécie de radar, ou antena, ligado o tempo todo, mas de modo "distraído", em uma atenção flutuante. Esse estado flutuante é importante, pois nos nossos exercícios e procedimentos as pessoas querem dar "o melhor de si", e esse melhor muitas vezes pode ser um amontoado de clichês sobre o que achamos que seria o mais legal de se colocar numa cena, ou mesmo uma ideia vaga e pomposa do que seria representar ou estar em cena. Isso serve também na vida. Nas entrelinhas, coisas importantes podem acontecer, quando estamos distraídos, quando não nos preocupamos em ser relevantes, solenes ou importantes. O psicanalista e dramaturgo Sergio Zlotnic nos traz contribuições para se pensar sobre os momentos de "recreio" e de intervalo.

Distrair-se é ser capaz de escutar os ecos contidos nas entrelinhas das palavras! Distração é caminho para ler poesia. E é o jeito "certo" de ir ao teatro. Distrair-se está longe das certezas, e é ingrediente daquele que cria e daquele que frui do que se produz no campo das artes... [...] Nessa zona de névoa dispersa, facilitamos que se revele a marca de uma força que nos ultrapassa: os deuses das pequenas coisas dando o ar da graça $^{42}$.

Ronaldo é um dos atores da Ser em Cena. Um dia, durante um intervalo em nossas atividades, contou-me casualmente que retirou o pulmão e o baço. A sua fala sobre os órgãos retirados do corpo e o modo como ele fez isso eram intrigantes. Assim como outras pessoas do nosso elenco, sua fala é feita das palavras essenciais, sem artigos ou proposições, e no caso do Ronaldo, ele fala com uma voz muito grave, mas que contrasta com a leveza com que faz o gesto de "despachar", ou que diz "foi pro espaço" depois de cada órgão do corpo que ele nomeia. Aquelas palavras ficaram anotadas no inventório, e mais

diante. O sensorialmente sentido parece ser a fonte da cognição. "GREINER, 2005. posição 1436.

${ }^{42}$ ZLOTNIC, Sergio, Nunca preste atenção! [on-line]. SP Escola de Teatro, 5 nov. 2014. Disponível em: <https://www.spescoladeteatro.org.br/noticia/nunca-preste-atencao/>. Acesso em: 3 jul. 2020. 
tarde foram acrescentadas à cena da alfândega, como mais uma pessoa que teria seus bens "inspecionados" pelo alfandegário ${ }^{43}$.

Assim, uma obra "concebida sempre na penumbra e na distração, como um filho, nasce na passagem entre dois campos. Entre o sono e a vigília [...]"44. Em nossas criações conjuntas, há que se estender esse estado para os encontros, e para o que pode acontecer que não esperávamos, "os deuses das pequenas coisas dando o ar da graça".

\section{7 bilhões e um}

O quanto eu sou feita das outras pessoas? O quanto delas tem em mim? O que é meu que veio do outro? Um dia eu trouxe esse atravessamento para o Grupo de Estudos e Criação em Performance, e começamos a tentar traduzir em ações e dar corpo a essas perguntas da maneira mais simples.

Chegamos a duas ações. Uma pessoa deita no chão. As outras vão dando forma àquele corpo, contornando-o com objetos pessoais tirados das bolsas ou do vestuário. Outra pessoa deita e alguém desenha o contorno de seu corpo. Ela levanta e, com o resto do grupo, preenche seu corpo com objetos pessoais. O mesmo é feito com os outros performers, cada um decidindo se quer o contorno ou o preenchimento.

Nesses diferentes tipos de desnudamento, "roupas, acessórios e objetos variados dão lugar à imagens de corpos construídos sob a medida alheia: o batom a contornar o ombro, a moeda que preenche o vão da virilha, um absorvente se une ao espelho e rascunha o formato de um quadril”45. No final desse movimento, temos quinze corpos contornados ou preenchidos por objetos no chão.

Ficamos por algumas semanas experimentando essas ações com variações: por exemplo, cada pessoa trazer um objeto importante e colocar em algum lugar do seu próprio corpo depois de "montado". Essas experiências duravam cerca de uma hora e aconteciam em silêncio. Uma espécie de ritual laico, que poderia ser subitamente desmanchado ou intensificado dependendo

\footnotetext{
${ }^{43}$ O desdobramento da criação dessa cena é descrito no trecho Desastres, alfândega e deriva, no Capítulo 3.

${ }^{44}$ Ibidem.

${ }^{45}$ Texto reflexivo sobre a ação de Rubya Caroline, performer do Gecep.
} 
do dia. "Era outro tipo de desnudamento. Eram os pequenos detalhes que saíam de dentro das bolsas e carteiras. Era mostrar aos outros o que você carrega, sua organização e suas supostas necessidades." ${ }^{\text {"46 }}$ Chamamos essa parte de primeiro movimento.

Fotografia 13 - Performace 7 bilhões e um - Grupo de estudos e criação em performance, 2014

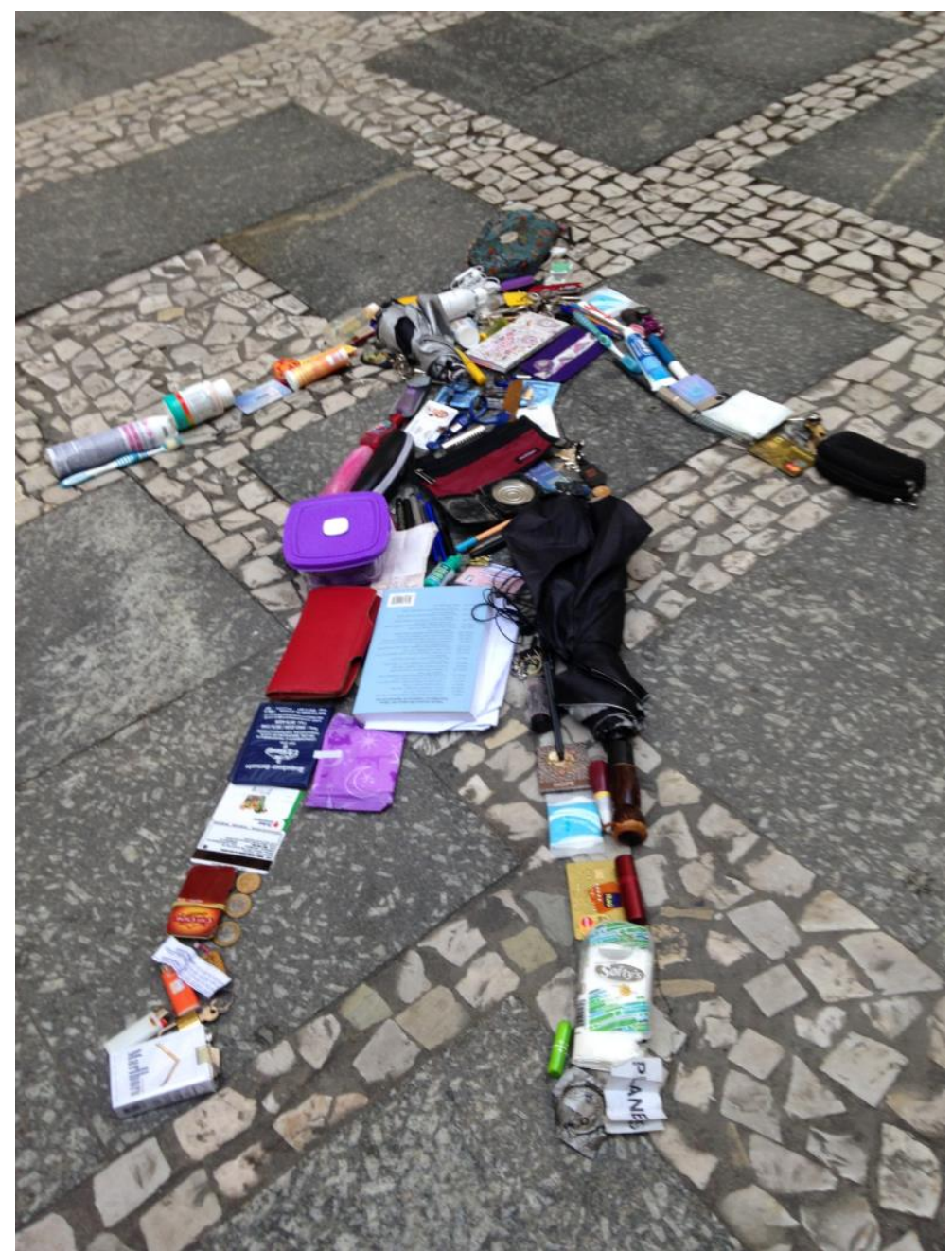

Foto: acervo pessoal.

No segundo movimento, cada pessoa criava relações entre seu corpo e o de outros, por meio do rearranjo dos objetos, de ações, de falas ou do que a pessoa quisesse fazer para criar conexões (também se poderia optar por não fazer nada) e reagir às ações dos outros. Esse movimento começava a

\footnotetext{
${ }^{46}$ Jaqueline Mazuchelli, perfomer do Gecep, reflexão sobre nosso processo.
} 
desmanchar as bordas dos corpos. "Eu sendo criada por outros, pelos encontros sempre a me refazer, até não saber se posso me chamar de eu."47

Poderia acontecer de ficarem corpos quase inalterados ou de haver um desmanche e mistura total. No terceiro movimento, recolhia-se de volta o que era nosso e o lixo era jogado fora. Eram ações que poderiam atingir momentos de intensidade, ou de insight, dependendo do que acontecia, de quais objetos eram colocados em quais partes do corpo.

Nessas experiências, diversas camadas se sobrepunham à composição e recomposição dos objetos e dos gestos. Retomo aqui a ideia de transversalidade do início do capítulo, de algo que acontecia entre as pessoas e os objetos. É interessante notar como, nessa perspectiva transversal, o biológico e o cultural se alimentam e se fundam reciprocamente e trazem novas possibilidades de leitura da nossa experiência:

Talvez as nossas ações mais básicas sejam as de ingerir e excretar, inspirar e expirar (que, evidentemente, dizem respeito a algo que entra e a algo que sai). Curiosamente, a comunicação também tem a ver com um entrar e sair, seja de lugares, recipientes, situações, espaços, tempos, de si mesmo, do outro, do grupo, e assim por diante. O que a perspectiva evolucionista aqui pleiteada agrega é a possibilidade de lidar com o binômio dentro/fora como complementaridade aberta e não como exterioridade mútua ${ }^{48}$.

\section{Então ele loucamente abriu a janela e viu o óbvio: seu corpo estava partido $^{49}$}

Apresentamos essa performance, intitulada 7 bilhões e um, no Sesc Pompeia, na área da convivência, em uma obra duracional de quatro horas. Criamos também uma instalação sonora que acontecia durante o segundo movimento. A partir do critério: o que nos formalo que carregamos/o que nos compõe, coletamos textos de origens diversas - revistas de variedades, obras de Freud, livros de biologia etc. -, de modo que tínhamos uma mistura de fragmentos que versavam sobre assuntos como comportamento dos átomos, ensinamentos budistas, regras de etiqueta em um jantar, código genético etc.

\footnotetext{
${ }^{47}$ Marilia Simões, perfomer do Gecep, reflexão sobre nosso processo.

48 GREINER, 2010, p.127.

49 Texto dramatúrgico do performer Paulo Araújo Dersu para a performance.
} 
Com esses trechos, gravamos áudios independentes, que eram disparados durante a performance a partir de duas caixas de som, de modo aleatório. Além de adicionar uma nova camada ao tema do quanto temos dos outros (e durante nosso processo percebemos que esse outro pode ser humano e não humano), a instalação sonora trazia outra dimensão à ideia de que "Viver é ser atravessado - mesmo sem querer" 50 .

Algumas pessoas do público espontaneamente participaram. Era uma ação que poderia ser lida em diversos níveis: simbólico, psicanalítico, coletivo, entre outros. A diversidade de feedbacks que tivemos, conversando ou ouvindo impressões do público, mostrou camadas que não havíamos pensado:

A: Eu já tô aqui há meia hora e não tô entendendo nada, nada.

B: Não, não é pra senhora entender nada.

A: Ué, então pra quê que faz?

Isso é muito lindo, me lembrou quando eu era criança, eu ficava fazendo essas coisas, é sobre a infância né?

Mãe, olha que legal, um humano de parede!

É só rico que perde tempo vendo esse tipo de arte.

A: O que é isso?

$B:$ que você acha que é?

A: Acho que é uma crítica ao acúmulo do sistema capitalista.

Acho que eles estão trabalhando a memória né? Acho que são coisas muito queridas de vocês e quando vocês colocam aí é a coisificação dos sentimentos.

Qual é o seu "boneco"? (Fica um tempo olhando os corpos no chão.) Posso dizer pelo que eu olhei que você é a pessoa mais coerente que tem aqui.

Esse povo aí é do Sus ou do Capes?

Nossa, isso é muito triste (começou a chorar e falou da finitude e da transitoriedade).

Essa diversidade de leituras pode servir de possíveis nortes para delimitarmos melhor o que queremos ou não queremos com essas ações. Nesse primeiro momento, a nossa criação teve o seu papel de nos fazer experimentar, com essas materialidades, o que carregamos. O que é

\footnotetext{
${ }^{50}$ Rubya Caroline, em texto para o projeto 7 bilhões e um.
} 
imprescindível, o que sobra, acumula, falta, se deteriora, "na inquietude da existência, naquilo que nos escapa e constitui" ${ }^{51}$.

\section{Dueto}

Estamos ensaiando um trecho de uma cena (que surgiu de uma improvisação), na qual algumas pessoas estão sentadas em cadeiras espalhadas assimetricamente pelo palco. Uma por vez faz uma dança com as mãos e os braços. Ilka está sentada e dança com uma das mãos. Disfarça o momento de pegar a outra mão, que não se movimenta sozinha. Ensaiamos juntas sem o disfarce. Primeiro o movimento de pegar uma mão com a outra, com a delicadeza que é preciso, então mover os dois braços e mãos que passeiam juntos em movimentos sinuosos e lentos. Ao final, com a ajuda da outra, pousar a mão na coxa com suavidade, palma depois dedos, e sem pressa a mão que se mexe ajeita a outra na coxa na melhor posição. É tudo parte da dança.

\section{Gangue dos pinos}

No início de um encontro, Orna contou até 23 e ao final falou "incisões". Depois outra pessoa apontou uma parte do corpo e falou: "pino". Então várias pessoas da turma foram apontando os pinos pelo corpo. Perguntei quem mais tinha, quase todas levantaram as mãos ou mostraram outras partes do corpo. Falei que elas não poderiam passar pela alfandega e que talvez pudessem ser uma gangue que traficaria alguma coisa. Risadas gerais. Acho que isso é um exemplo de se abrir ao inesperado e tentar ver as coisas de outro jeito, "retomar o corpo naquilo que the é mais próprio, sua dor no encontro com a exterioridade, sua condição de corpo afetado pelas forças do mundo" "52. E ao mesmo tempo, fazer essa retomada, ou reconhecimento, de uma forma não assistencialista ou piedosa.

Esses dois casos, da gangue dos pinos e da dança das mãos de Kátia tocam em alguns pontos importantes. Como diretora e professora, quando lido

\footnotetext{
51 Ibidem.

52 PELBART, O corpo do Informe. In: GREINER, Christine; AMORIM, Cláudia. Leituras do corpo. São Paulo: Annablume, 2003. p.72.
} 
com pessoas que trazem questões que tem também aspectos clínicos, procuro desenvolver uma sensibilidade ao mesmo tempo estética e ética.

No caso da "gangue", eu não tinha como negar a dor de várias das pessoas do grupo falando ou apontando seus pinos e incisões pelo corpo, mas ao mesmo tempo, inventar uma ficção possível para esses gestos é tentar encontrar uma forma para nossa dor - que acredito ser uma das coisas que fazemos como artistas, com pinos ou não. Dirigir um espetáculo, sem ser de modo piedoso ou assistencialista, inclui tentar encontrar a melhor forma para que um atravessamento (que pode ser uma dor física, uma questão que a pessoa traz ou uma urgência) possa ser metabolizado de algum modo e compartilhado com outras pessoas.

Ao dar um feedback sobre uma improvisação ou dar uma ideia de cena para alguém, essa percepção estética e ética inclui delicadeza. A dança das mãos, na qual procurei mostrar para llka que a mão inerte dela também fazia parte, envolve questões de aceitação de um corpo diferente do que sempre foi, e também de uma linguagem estética muitas vezes também diferente de um certo padrão. Costumo ser bem direta ao tentar explicar como é o tipo de beleza que eu vejo sendo instaurada ali, mas ao mesmo tempo, se a pessoa não estiver à vontade com o que estou propondo, podemos não fazer a cena, ou ainda imaginar outras soluções estéticas.

As investigações das educadoras Camila Alves e Marcia Moraes sobre capacitismo e interdependência trazem contribuições valiosas ao descrever "narrativas que colocam em xeque as concepções hegemônicas da deficiência como falta" 53 . Elas também perguntam como possibilitar "o surgimento de novas e outras histórias a respeito da vida das pessoas com deficiência e, desse modo, fazer proliferar outras versões para além de um romantismo ou um fatalismo" 54 . Em outro momento, elas descrevem como estão dispostas, em seus trabalhos,

\footnotetext{
${ }^{53}$ ALVES, Camila Araújo; MORAES, Márcia. Entre histórias e mediações: um caminho para acessibilidade estética em espaços culturais. Psicologia: Ciência e Profissão. Brasília, v. 38, n. 3, p.584-594, set. 2018. Disponível em:

<http://www.scielo.br/scielo.php?script=sci_arttext\&pid=S141498932018000300584\&lng=pt\&nrm=iso >. Acesso em: 3 jul. 2020.

${ }^{54}$ Ibidem, p.5. Recomendo a leitura desse artigo que descreve, por meio de uma experiência sensorial estética de ressignificação, uma possibilidade de resposta a essa pergunta, além de todo o encadeamento de conceitos e práticas que tratam desse tema.
} 
[...] a pensar, como no âmbito da cultura, essas versões a respeito da história da deficiência/diferença podem ser recontadas, feitas, refeitas, recriadas, desestabilizando assim o hegemônico - versões da deficiência como déficit, como superação, versões desencarnadas da deficiência - a partir do experimental, no sentido de experimentações encarnadas, do que estar por vir ${ }^{55}$.

Acredito que nossas práticas apresentam possibilidades de resposta para essas perguntas. Abrir-nos para o inusitado da situação de várias pessoas com pinos nos corpos sem ser condescendente ou achar que são um exemplo de superação gerou essa ideia da gangue, que dialoga criativamente com suas especificidades, assim como descobrir como se dança com uma parte do corpo que não se move. Estas são tentativas de se experimentar outras e novas histórias a partir do que é, sem tirar (as pessoas de sua humanidade e tratá-las como incapazes) nem por (uma narrativa heroica de superação que também blinda nosso olhar para o que elas de fato são).

\section{ESPAÇOS E LUGARES}

O lugar é o quadro de uma referência pragmática ao mundo, do qual the vêm solicitações e ordens precisas de ações condicionadas, mas é também o teatro insubstituível das paixões humanas, responsáveis, através da ação comunicativa, pelas mais diversas manifestações da espontaneidade e da criatividade ${ }^{56}$.

Imaginemos que o lugar é definido, além de uma escala geográfica, por uma escala existencial. Por meio de exemplos do curso de performance do programa lgual Diferente do MAM, partiremos dessa definição para perceber como diferentes espaços cênicos e arquitetônicos podem determinar relações e acontecimentos; e como as relações com o espaço tem também dimensões subjetivas e afetivas.

\footnotetext{
55 Ibidem, p.4.

56 SANTOS, Milton. A natureza do espaço: técnica e tempo, razão e emoção. São Paulo: Edusp, 2002.p.218
} 
Fotografia 14 - Performance Oito léguas para Fibo - Igual Diferente - Mostra Museu Dançante - MAM, 2014

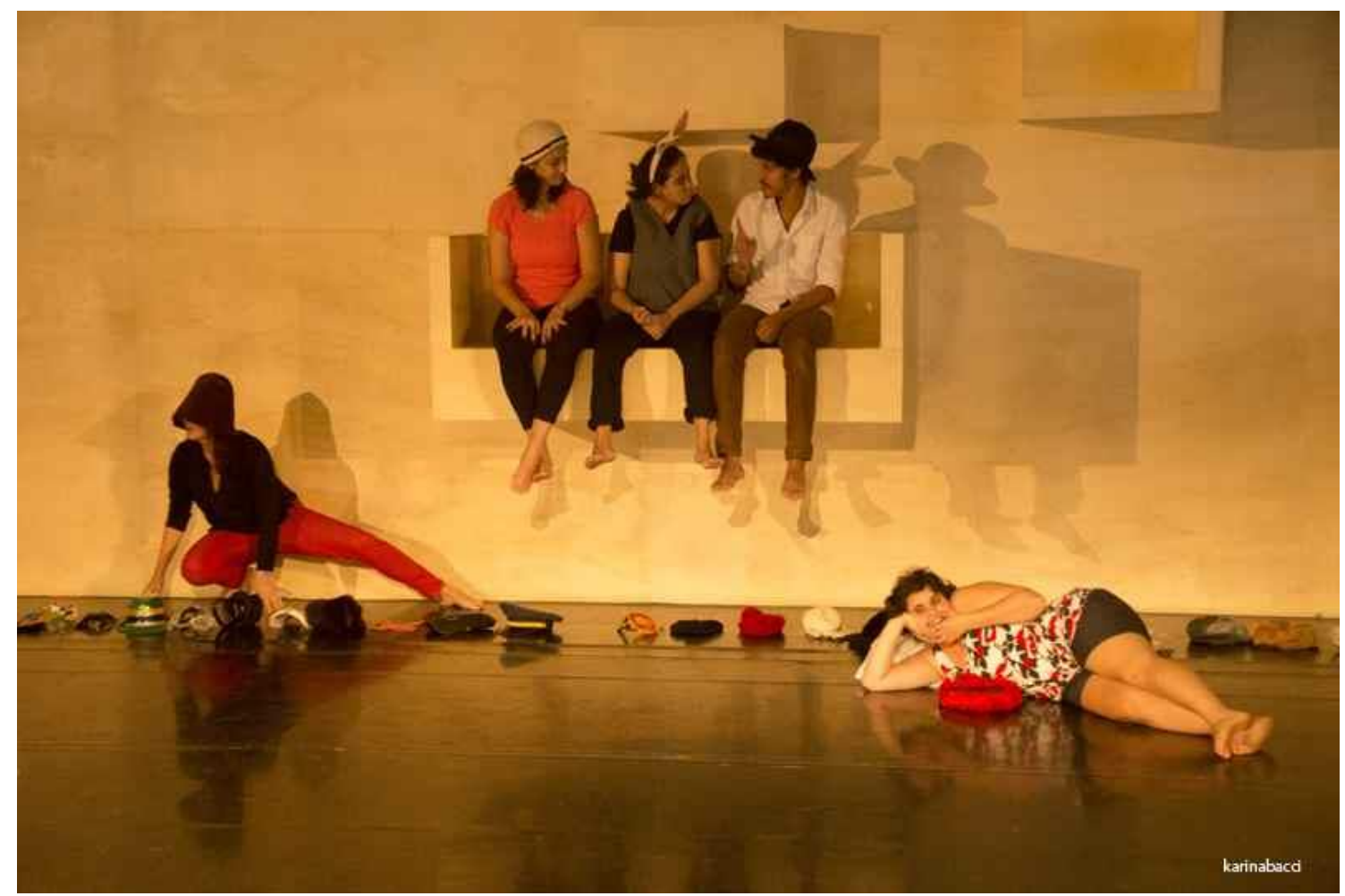

Carol Fomin, Mariana Carmo, Lívia Pellegrini, Leonardo Castilho, Olivia Lerner. Foto: Karina Bacci.

Durante toda a trajetória do curso, experimentamos nossos encontros e apresentações em diferentes lugares como o parque, a marquise, o auditório, o terceiro andar do prédio da bienal. Em alguns momentos, essas experimentações podem acontecer de maneira pontual e imprevisível: no meio de um exercício, podemos decidir abrir a porta do ateliê, que fica na marquise, e continuar a proposta no vão anexo ao museu, ou ir para o gramado em frente fazer alguma atividade. Mas em sua maioria essas experimentações são planejadas. Em nossas turmas, há uma relação forte do espaço arquitetônico, não só com a organização espacial dos participantes, mas com sua própria organização subjetiva, que se ancora também na materialidade do ambiente em que está para criação das cenas.

Em 2018, quando estávamos trabalhando com o tema da metamorfose, fizemos experiências de deslocamento das personas e sua transformação entre as árvores do parque; já nos apresentamos (que inclui outros encontros para apropriação do espaço e ensaios) no auditório (2013), na marquise em 
frente da $\operatorname{Aranha}^{57}$ (2014) ou dentro do museu, quando fomos convidados para participar da mostra Museu Dançante (2014). Já nos apresentamos também dentro do ateliê.

Ir para lugares diferentes dá corpo às nossas investigações. Geralmente, vamos para um novo espaço quando já temos algum material cênico elaborado. Ao entrar em contato com outro ambiente, as nossas cenas e improvisações têm que passar por uma transformação, pois as características físicas e subjetivas do novo espaço fazem com que não seja possível repetir exatamente o que fazíamos antes, no ateliê. A mudança de lugar gera uma instabilidade; essa instabilidade suscita uma reação na qual o material que temos ganha um novo corpo, se afirma, mesmo que em sua precariedade. Além disso, o próprio deslocamento para esses lugares, os acordos e a energia coletiva suscitados já são em si uma aventura grupal e um acontecimento.

Fotografia 15 - Curso de performance do Igual Diferente - MAM, 2018

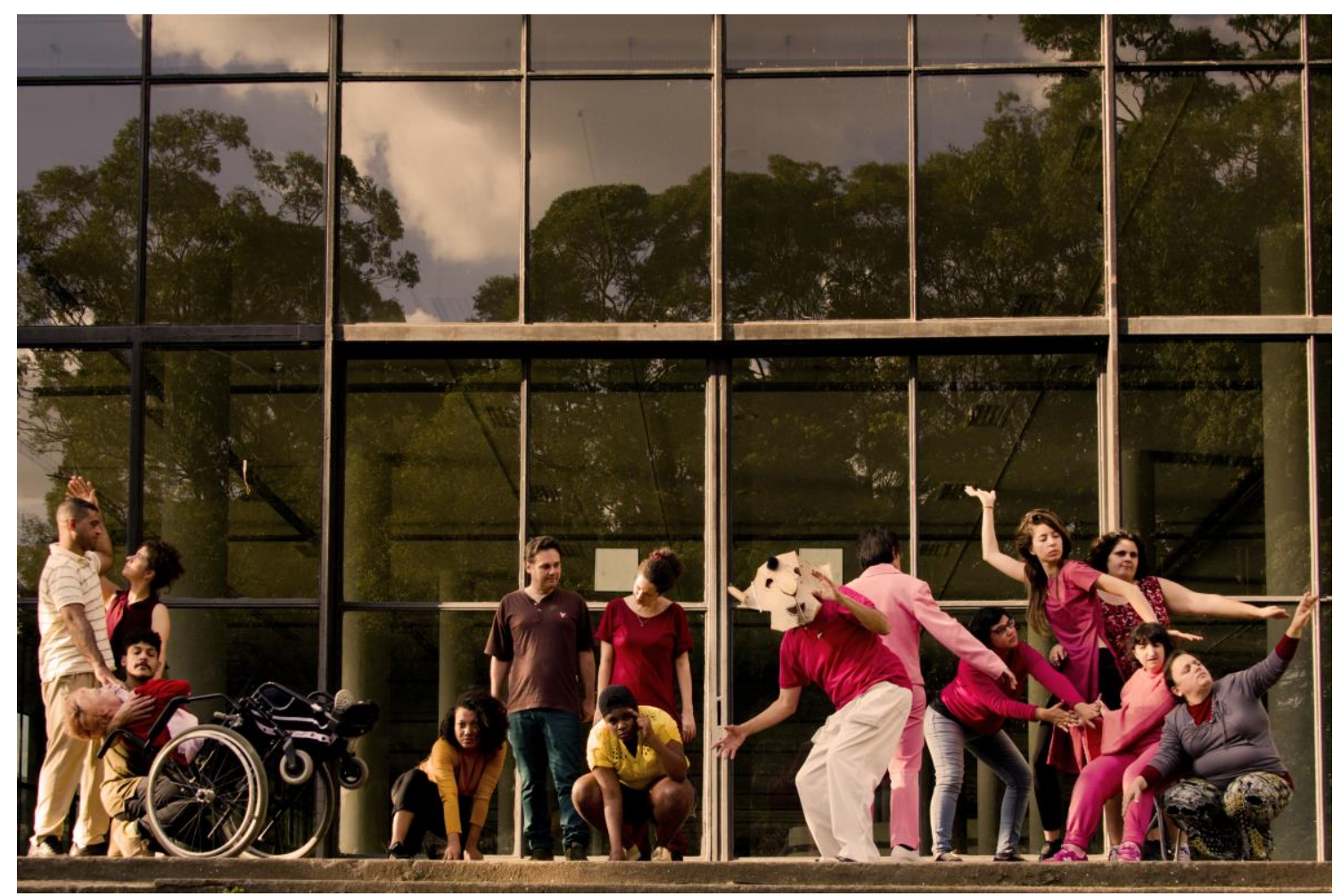

Da esquerda para direita, de cima para baixo: Júlio César, Laysa Elias, Armando Khoury, Elisa Band, Paulo Dersu, Cristina Márcia, Laís Barreto, Barbara Jimenez, Olivia Lerner, Alessandra Grimaldi, Erika Mota, Shirley Vieira, Ana Cardelli, Andrea Passarelli. Foto: Karina Bacci.

${ }^{57}$ Escultura de Louise Bourgeois. 
A escolha e a convivência com o espaço são essenciais não só na cena: "é necessário criar, recriar, de uma maneira incessante, lugares, espaços, sítios, sempre ameaçados de aniquilamento"58. Oury, em seu trabalho e convivência com pessoas que passaram por episódios de loucura ou psicose (e podemos acrescentar aqui outras tantas pessoas que se encontram em existências erráticas), lembra-nos de que "uma das coisas mais essenciais, mais elementares, é que antes de querer que eles contem sua 'história', ou de orientá-los em uma temporalidade, é preciso que primeiro eles possam situar-

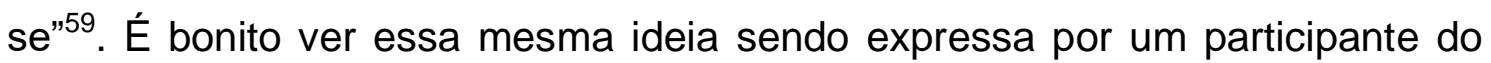
curso, Dersu, em 2014, em uma conversa: "ainda não temos a história, mas temos uma geografia"

\section{Linhas de fuga}

A uns trezentos ou quatrocentos metros da pirâmide me inclinei, peguei um punhado de areia, deixei-o cair silenciosamente um pouco mais longe e disse em voz baixa: estou modificando o Saara. O fato era mínimo, mas essas palavras pouco engenhosas eram exatas e pensei que havia sido necessária toda minha vida para que eu pudesse dizêlas $^{61}$.

É possível experimentar diferentes relações com o mesmo espaço e criar diferentes estratégias para transformar espaços em lugares. Começamos em 2014 a delimitar, em alguns encontros, com fita crepe, linhas no chão do ateliê que estabeleciam um dentro e um fora, e que variavam a cada dia, criando diferentes tipos de espacialização. Poderia ser um corredor, retângulo, ou dois retângulos, um grande quadrado etc. Também poderíamos dar indicações a partir das formas: de coisas que acontecem durante a passagem pelo corredor; sair diferente do que entrou; transformações dentro do quadrado; o seu corpo fica diferente do que é do lado de fora; um grande triângulo no qual quem ficar em cada vértice obedece a uma regra; língua de sinais, expressão com o corpo todo, expressão com o rosto.

\footnotetext{
${ }^{58}$ OURY, 2009, p.265.

59 Ibidem, p. 265

60 Dersu (Paulo Araujo Cruz).

${ }^{61}$ BORGES, Jorge Luís. Atlas. São Paulo: Companhia das Letras. 2010. p.27.
} 
Essa experiência permite que se tenha um tanto de indeterminação nos corpos e nas ações, e outro tanto de limite. Esse limite, contudo, também pode ser transposto, como acontecia várias vezes: algumas pessoas se relacionavam às marcas no chão e outras passavam por cima. Experimentamos várias formas de desenhos no chão, e muitas vezes com uma resposta forte das pessoas, de produção de outros corpos e jeitos de se mover. Trazendo novamente Oury,

Quando se diz "o espaço", trata-se de uma topologia particular. Trata-se de tentar desimpedir - mas com que trabalho! "Espaços do dizer" [...]. O espaço do dizer é o espaço que permite que haja possibilidade do "dizer". Pois nos processos psicóticos, o que está alterado, as "lesões", são lesões da "fabricação do dizer". [...] Há dificuldades frequentemente insuperáveis para que se possa "dizer" alguma coisa. Dizer, isto não quer dizer falar: frequentemente o dizer está no silêncio. [...] E nesse sentido, para que haja emergência, uma limitação é necessária. É essencial recuperar o nível de existência do psicótico, o qual não consegue justamente delimitar-se ${ }^{62}$.

A restrição ou limite espacial funcionou como um estímulo, proporcionando, com a percepção de diferentes "dentros" e "foras", outras geografias corporais e coletivas, espaços do dizer (com palavras, com o corpo, com silêncios). Oury se refere a seu trabalho em instituições psiquiátricas. Trazendo-a para nosso cotidiano de criação, essa reflexão é pertinente não somente aos ditos psicóticos (que sim, se beneficiam com essa espacialização dentro do espaço, mesmo que para passar por cima), mas a todas as pessoas do nosso coletivo (e arrisco dizer coletivos artísticos de modo geral).

$\mathrm{Na}$ criação de cenas, improvisações e performances, todos nós temos nossas "lesões", ou fissuras, na fabricação do dizer (novamente seja um dizer com o corpo ou com as palavras), e quando Oury escreve que, para que haja emergência, uma limitação é necessária, podemos pensar tanto no contorno que um coletivo dá para as pessoas-artistas se expressarem, quanto em um dispositivo espacial de criação de cena como espaços delimitados por fita crepe.

\footnotetext{
${ }^{62}$ OURY, 2009. p.115.
} 


\section{Uma visita}

Em 2018, tivemos a visita da Erin Manning, uma filósofa e artista interdisciplinar que trabalha na Universidade de Concordia, em Montreal, com filosofia, dança e neurodiversidade. Ela veio com participantes do seu grupo senselab, e experimentamos juntos algumas das nossas dinâmicas. Depois, sem enunciar com palavras, Erin propôs uma interação com objetos e corpos pelo espaço: começou colocando uma cadeira virada na sala, então pendurou uma caneca de metal no pé da cadeira, as pessoas foram colocando objetos, tecidos, acrescentando várias cadeiras e se colocando no espaço, de modo que, em um certo momento, tivemos a montagem coletiva de uma grande instalação com objetos e pessoas que se modificava a todo momento.

Criamos um fluxo como o que fazíamos em nossas improvisações, em que um movimento pode nascer de outro, transformar-se, e nascem ondas coletivas que se modificam, misturam-se, desmancham-se em pequenos grupos, juntam-se, quase se extinguem e começam de novo, e assim por diante, em uma dinâmica que pode se estender por horas. Em nossa conversa no final da visita, ela observou que o grupo tem uma base forte de sustentação, se autoalimenta e vai transformando uma coisa na outra. Erin percebeu uma característica do grupo, e também trouxe elementos que foram para nós, aprendizados: a montagem da instalação-performance coletiva de objetos e 0 seu modo de conduzir, por meio de gestos e sem fazer um enunciado verbal inicial. Tanto a disposição dos objetos quanto o enunciado corporal podem também ser vistos como elementos que produzem diferentes relações com o espaço, que se transforma e é imantado, passando então a existir como um lugar.

Convidamos Erin pois ela fazia parte da bibliografia como uma autora (e artista) que eu admirava de longe. Ser visitada por uma referência bibliográfica foi surpreendente: depois do nosso encontro, li seu livro Sempre mais que um, o que possibilitou observar com outra profundidade suas proposições daquele dia, e imaginar desdobramentos futuros a partir dos aprendizados do encontro.

Reproduzo algumas de suas reflexões a seguir, tentando provocar a mesma sensação que tive quando li seu livro e vi como esses conceitos se amalgamaram ao que estávamos fazendo. 
Quando Erin propôs com gestos a interação/instalação com cadeiras e objetos, os participantes que têm autismo ou que se relacionam por lógicas próprias de linguagem foram as primeiras pessoas a interagir com os objetos, de modo que pudemos ver um exemplo vivo de como "[a proposição] não precisa ser submetida à linguagem", e também do modo com que "as proposições intensificam, atenuam, inibem, transmutam não somente o sentido, mas a força afetiva [da] criação ${ }^{63}$.

Vimos também como a proposição não verbal pôde suscitar uma resposta tão direta para essas pessoas, que entendem o mundo de maneira processual: "um objeto é aquilo que ele é capaz de fazer [...]. Não pensemos o objeto ontologicamente, mas processualmente" ${ }^{44}$. Em relação ao nosso fluxo de improvisações que ganhava consistência e se desmanchava, podemos relacionar o "por um triz" de nossos processos com sua reflexão de que "a obra funciona quando a construção é sentida não como uma forma por si só, mas como força de forma - quando a forma ou a estrutura está quase em processo de desestruturação" ${ }^{65}$. Ainda dentro dessa perspectiva de um fluxo, podemos relacionar nossa ideia de transversalidade descrita no inicio do capítulo com o pensamento de Erin de que "a dança está acontecendo com e através dos corpos, em vez de acontecer nos próprios corpos. Os corpos dançam de acordo com a expressão de um movimento que, por sua vez, os dança"66.

E por fim, uma frase que traduz não somente o encontro daquele dia, mas do que tentamos exercer em nosso cotidiano e nas nossas criações: "E não há corpo que não seja infinitamente mais que um"67.

\footnotetext{
${ }^{63}$ MANNING, Erin. Always More than One: Individuation's Dance. [s.I.]: Duke University Press, 2013. p.96, tradução livre de Francisco Trento.

${ }^{64}$ Ibidem, p.95.

${ }^{65}$ Ibidem, p.121.

${ }^{66}$ Ibidem, p.120, itálico da autora.

${ }^{67}$ Ibidem, p.230.
} 


\section{IMPASSES}

\section{Cuidados}

Quando as pessoas chegam na Ser em Cena, muitas vezes estão em um momento vulnerável, tentando achar modos de viver após um acidente. É compreensível que, nesse momento de reconfiguração e fragilidade, as familiares e as cuidadoras queiram acompanhar mais de perto as atividades ${ }^{68}$. Combinamos que elas assistam um encontro para ver a dinâmica da aula e depois não participem mais (mas pela arquitetura de onde nos encontramos, algumas vem "espiar" por um vão abaixo da escada as atividades). Além disso, sempre chegam pessoas para a triagem de novos integrantes, que aguardam em um lugar onde é possível olharem e serem olhadas por nós. Esse fluxo de pessoas exteriores aos encontros não tem como ser evitado.

Se por um lado familiarizam os novos e os acompanhantes às nossas atividades, por outro, nesses momentos sinto uma desproteção minha e do grupo por essa camada extra de presenças e olhares. O que temos feito é reforçar o acordo coletivo com os acompanhantes de não assistirem, e restringir as visitas às pessoas que já fizeram a entrevista e querem ver como são os encontros.

As participações de pessoas exteriores ao processo podem trazer gestos que escapam da área do teatro e envolvem projeções e desejos que podem não coincidir com o que estamos buscando (por exemplo, uma tia me perguntando no meio do ensaio geral se a peça não poderia ser mais feliz, ou a mãe que me censura porque a filha deveria estar mais na frente do palco e ter mais falas). Nesses casos, tentamos lidar de uma maneira respeitosa e acolhedora, e nos casos mais difíceis temos a colaboração das equipes de psicologia, fonoaudiologia e mesmo produção e comunicação, que, como já falado, se desdobram em várias funções e constituem uma interlocução importante.

\footnotetext{
${ }^{68}$ As cuidadoras são em sua maioria mulheres, familiares ou acompanhantes contratadas. Para quem quiser se aprofundar, há estudos importantes que ligam a questão da deficiência e seus cuidados a dimensões de raça, gênero e classe. Sugiro as falas da educadora Camila Alves disponíveis no youtube: <https://www.youtube.com/watch?v=vBIV-AaGKY\&feature=youtu.be> e <https://www.youtube.com/watch?v=y_TBLoeN8Z>. Acesso em: 8 jun. 2020.
} 
São questões com que temos que conviver e nas quais não há um denominador comum de como tratar ou estabelecer regras fixas. Algumas cuidadoras e familiares-acompanhantes ajudam bastante na produção, na logística, costuram figurinos, ajudam a vestir e maquiar, fazem adereços de cenário e trazem lanches nos encontros e apresentações, estabelecendo uma parceria potente (operacional e afetiva). Outras acabaram entrando em cena e são parte do elenco. Todos esses gestos trazem uma contribuição valiosa. Com um elenco de 75 pessoas e impossibilidade de uma equipe maior de apoio, esse arranjo funciona, dentro das suas precariedades e possibilidades.

\section{Pai nosso}

No dia da entrevista para trabalhar na Ser em Cena percebi que a turma estava rezando o pai nosso. Olhei com curiosidade, na verdade com um pouco de susto, pois já havia feito a entrevista, tinha ido bem e gostado muito das pessoas da equipe. Nos primeiros encontros, percebi que era uma imposição de alguns integrantes, que não terminavam sem realizar a reza coletiva. Todos em círculo de mãos dadas fazendo a oração, formato cristalizado de um pequeno ritual que finaliza um encontro de teatro e, ao mesmo tempo, mais um símbolo da imposição de um modo de vida sobre outros.

Fui admitida na entrevista e quando entrei na Ser em Cena, em um dos primeiros encontros, pensei em uma estratégia: após as atividades do dia, propus uma finalização que fazemos várias vezes nos outros coletivos, e imaginei que poderia ser um ritual substituto ao pai nosso. Em círculo, imaginamos água dentro da roda de pessoas (não é para interpretar mas sentir), quem quiser coloca as mãos, entra inteiro ou joga um pouco de água em algum colega, depois falamos 1, 2, 3 e "guardamos" a experiência do dia no universo ou na nossa barriga ou em outra parte do corpo, dependendo do dia $^{69}$.

Tentei fazer isso discretamente como ritual de substituição: fizemos as ações, terminando no gesto e som coletivo de jogar a energia para cima, que têm uma qualidade de finalização bem claro. Y., o defensor mais ardoroso do pai nosso, levantou a voz e comandou: agora vamos fazer o pai nosso, ao que todos obedeceram e rezaram. Durante a reza recalculei a rota. Ao final da

\footnotetext{
${ }^{69}$ Esse procedimento foi feito a partir de workshop com Madalena Bernardes.
} 
oração, perguntei se alguém gostaria de fazer algum outro tipo de reza ou falar alguma coisa. Ninguém se manifestou, e continuei repetindo isso durante todos os encontros seguintes. Nada havia aparentemente mudado, mas ao mesmo tempo eu sentia que fazer essa pergunta sempre, depois do pai nosso, era o jeito possível de lidar com aquilo, e de alguma forma mínima promovia uma fresta.

Um dia a Erika, que trabalhava na Ser Cena e é budista (e fora da aula já havia comentado estar gostando dessa nova proposta, pois nem todos são católicos e alguns nem têm religião), se ofereceu para fazermos um ommmm coletivo, o que fizemos. Y. ficou um pouco desconcertado, mas não teve o que fazer. Aos poucos fomos diluindo o pai nosso. Há dias em que experimentamos outras rezas, outros dias (que foram ficando os mais frequentes), reza nenhuma, descobrindo outras maneiras de finalizar o ritual. Uma vez voltamos ao pai nosso na ocasião de uma morte, outra vez coloquei uma música de lemanjá, e assim vamos.

\section{NÃO FAZER}

\section{Desedificante}

Algumas vezes, o coletivo está muito impregnado de discursos edificantes, e é delicado saber lidar com esse pacote pronto de discursos que tentam apaziguar os espíritos, pois é isso o que muitas pessoas têm para se apoiar depois do trauma. Não sei a melhor forma de lidar com isso, mas os acontecimentos do dia a dia fazem surgir jeitos. É como se fosse uma batalha subterrânea na qual tenho que ficar atenta nas palavras, nos gestos, nos comportamentos, sempre à procura de algo que possa desconstruir um pouco a fortaleza de autoajuda e mostrar que existem também modos múltiplos, nuançados de perceber e sentir.

Um dia, no início do encontro, quando perguntei como estavam se sentindo naquele momento, Orna fez um desabafo. Ela não consegue falar muitas palavras e soltou um "puta merda!" bem sonoro. Algumas pessoas riram um pouco, outras ficaram sem graça ou olharam para mim como que para entender o que achar daquilo. Eu falei que pode ser bom fazer esse 
descarrego, e se alguém mais queria fazer, poderia ser com palavras ou só com sons. (Nessa turma as pessoas têm poucas ou quase nenhuma palavra de português no vocabulário.) Várias levantavam a mão e faziam um som com essa intenção de "colocar um incômodo para fora", descarregar, dar um basta.

Eu não teria tido essa iniciativa se Orna não começasse, e as outras pessoas não experimentariam se eu não interferisse e abrisse a possibilidade:

O tornar-se com envolve um processo de transformação recíproco no qual o que se põe em ação não é, de modo algum, uma relação entre dois indivíduos, mas antes, uma articulação que envolve múltiplas relacionalidades e interdependências. [...] [Estamos compondo] um comum, cotidianamente $^{70}$.

As mais tímidas, que riram antes, também experimentaram quando fizemos descarrego coletivo, todas emitindo o som ao mesmo tempo. Achei que foi um momento forte, que a turma aderiu com intensidade a essa proposta, talvez por poder entrar em contato com a raiva, que é um sentimento que existe e não deveria ser abafado. Às vezes pode ser preciso dar o pior de si.

\section{Vidro com chuva}

O curso de performance que eu ministrei na SP Escola de Teatro Centro de Formação das Artes do Palco, e que deu origem ao Grupo de Estudos e Criação em Performance, aconteceu de segunda a sábado durante três semanas, das $19 \mathrm{~h}$ às $22 \mathrm{~h}$. Em um dos primeiros encontros, quando as pessoas estavam acabando de chegar e de se acomodar, começou a chover. A sala fica no sétimo andar e tem uma das paredes inteira de vidro, na qual se pode ver a praça Roosevelt, a igreja da Consolação, a avenida atrás e uma parte da cidade. Não sei se pela vista, chuva ou pelo momento da chegada, mas, mesmo tendo as atividades das três horas seguintes planejadas, senti que precisávamos viver aquele momento. Fiquei sentada olhando a chuva, e as pessoas foram fazendo o mesmo, as que já estavam e as que foram chegando. Ficamos assim uns trinta minutos.

\footnotetext{
${ }^{70}$ ALVES, MORAES, 2018, itálico meu.
} 
Foi uma experiência que nos atravessou. Sem enunciado nem conversa depois. Ninguém dormiu nem olhou para outro lugar (não que isso fosse um problema, mas descrevo esse estado coletivo para dar uma ideia do acontecimento). Voltamos para as atividades, e ao final do dia na conversa geral as pessoas relataram terem sentido essa espécie de epifania. Parece vago falar em sentir algo, epifania, viver o momento, mas o que temos são essas sensações e os relatos. Ao final das três semanas do curso, muitas pessoas relataram a intensidade daquele momento, e ainda hoje quando encontro aqui e ali alguns integrantes, ainda compartilhamos a sensação de ter vivido uma epifania coletiva. Um bom encontro, para Espinoza, é algo que afeta, ativa, potencializando forças de vida. Se abrir para um aparente não fazer pode gerar encontros (com a chuva, com o tempo escorrendo, com a proximidade das pessoas) que ampliam a capacidade de ação.

\section{DESOBEDECER}

Como achar formas de ser um coletivo que permite uma dissonância, que não é uníssono, nem sólido, nem fixo, e ainda assim é um grupo?

Uma das riquezas dos encontros com esses coletivos é a sua indeterminação: por mais paradoxal que pareça, a coesão do coletivo se dá justamente por estar sempre se desmanchando e se recompondo, descobrindo novas formas de estar-sendo um coletivo, mas em vias-de, nunca de modo pronto, constituído, ou seguindo à risca o planejado. Esta abertura à imprevisibilidade nos torna insubmissos a lógicas totalizantes.

Alguns permitem um maior grau de indeterminação, mas em outros uma pequena abertura ao imprevisível já pode ser revolucionária.

Há uma aposta na liberdade, na experimentação e na singularidade, não somente dos participantes dos coletivos, mas dos diretores-professores-artistas que colocam também seus desejos na roda. Colocar-se, na criação de cenas e nesta dissertação, tem a ver com tentar inventar ou descobrir a própria escrita.

Do mesmo modo, participam também as equipes das instituições das quais pertencem esses coletivos, que não somente estruturam, mas pensam 
junto formas de potencializar a experiência de criação: Daina Leyton, educadora, psicóloga e coordenadora do MAM Educativo, descreve que acessibilidade, não é "apenas promover acesso ao que já existe, mas sim pensar e construir a realidade que se deseja viver" ${ }^{n 1}$, ao que a gente deseja que exista.

No início do espetáculo Do outro lado do oceano, criado com a ONG Ser em Cena, Ribeiro ${ }^{72}$ contava a história do pescador que pegou um peixe tão grande que entortou o rio, precisou ser carregado em uma carreta de 64 pneus, e quando foram fotografar, só o retrato do peixe pesava 38 quilos. As nossas investigações e estudos de caso neste capítulo - a partir de assuntos como o improviso na arte e na vida, os jeitos de se pensar o corpo, os diferentes tipos de heterogeneidade, os modos de diferir de si mesmo, a invenção de outros de si ou a experimentação de espaços e lugares - têm um pouco do peso e da leveza desta foto, que inventa outras lógicas nas quais não importa tanto se o peixe existiu ou não, mas sim a própria invenção (da história, assim como dos nossos procedimentos e criações), pois esta já é de alguma forma o colocar no mundo o que a gente deseja que exista.

Termino este capítulo seguindo as pistas da performer Ana Cardelli. Seus e-mails e mensagens escritas têm uma lógica própria. Ela coloca pontos entre as palavras, suscitando uma leitura telegráfica que traduz seu modo de falar, singular e poético. Do mesmo modo, escrever este capítulo também foi uma tentativa, assim como seu objeto de estudo, de acolher um excesso de ideias, assuntos, possibilidades e temas, (espero que) perdendo-se o suficiente para não se desmanchar e nem ficar refém de um excesso de ordenação. Um dia desses, recebi uma mensagem de Ana que relatava estar com saudades dos encontros e terminava assim: "Grupo. Dança. Experiência. Água. 123. E já aplaudir. Embora. Um. Beijo. Abraço. Da. Ana".

\footnotetext{
${ }^{71}$ LEYTON, Um mundo possível, p.9. In: Igual Diferente.

72 José Lopes Ribeiro (1941 - 2019), foi ator da Ser em Cena e um dos primeiros integrantes da ONG.
} 
Fotografia 16 - Curso de performance do Igual Diferente - MAM, 2015

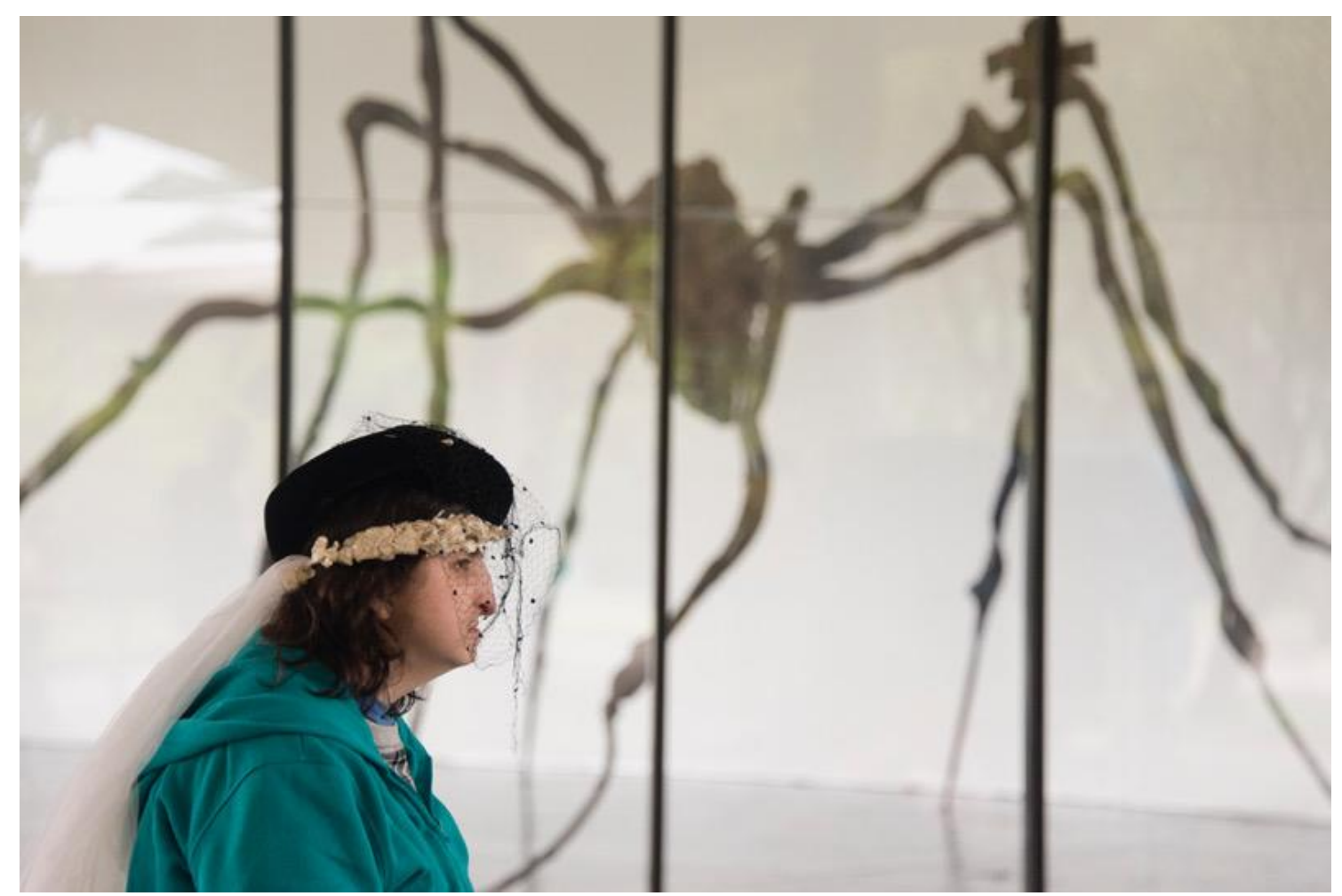

Ana Cardelli. Foto: Karina Bacci. 
PARTE III - MODOS DE EXISTIR 
Toda matéria ondula de possibilidades infinitas.

(SCHULZ, Bruno. Lojas de canela. São Paulo: CosacNaify, 2014. p.45.) 


\section{TATEAR JUNTO}

\section{No dia 22 de abril de 2011 você me amava?}

Rogério perguntou se seu corpo tinha ficado na sala durante o relaxamento de olhos fechados. Olivia quer saber se eu a amava no dia 22 de abril de 2011, ou quantas terças-feiras existem. Sam é fluente em línguas inventadas. A cantora desvirtuosa tem seus pertences roubados. Um alfandegário confisca o tempo de um passageiro.

O que essa coleção tem em comum? Assim como a do capítulo anterior, também são momentos dos encontros, ensaios e apresentações dos coletivos investigados $^{1}$. Em uma primeira impressão, percebemos algo que escapa, não cabe, desencaixa. Esse desencaixe tem um pouco de enigma, causa curiosidade e acorda alguma coisa em nossa percepção.

No capítulo anterior, foi descrito como surgem os materiais criativos nos coletivos; que tipo de atmosfera, e de estímulos acontecem para que esse material possa surgir, como sustentar e legitimar essas criações e que tipo de encontros podemos instaurar para que a criação emerja em uma potência mais frutífera.

Neste capítulo, iremos abordar como esses materiais são organizados em um experimento cênico. Continuamos nossa análise dos dispositivos de criação a partir das singularidades, mas com ênfase nas resultantes desses processos: a criação de espetáculos, performances e de um filme.

Investigamos como a organização desses materiais abrem possibilidades de dramaturgia e encenação em relação à linguagem teatral, no sentido de se rever alguns aspectos do teatro contemporâneo à luz dos coletivos heterogêneos: o tempo nos diálogos, a criação de outros de si, a invenção de línguas e o deslocamento de uma ideia harmônica de belo. Assim, heterogêneas também serão as obras: "Por meio de novas arquiteturas, a arte

\footnotetext{
${ }^{1}$ Cia. Ueinzz, turma do curso de performance do programa Igual Diferente do Museu de Arte Moderna - SP, grupo de teatro da ONG Ser em Cena e Grupo de Estudos e Criação em Performance.
} 
se torna captação e composição de heterogêneos, em vez de caminhar, interminavelmente, para a sua suposta essência”².

Pensar nos processos de criação é também pensar no compartilhamento, ou abertura desses processos: como podemos montar uma estrutura de apresentação final sem submeter os sentidos que surgem apenas ao domínio da significação? Como criar uma dramaturgia que comporte partitura e acaso? Como elaborar o material para uma apresentação sem enclausurar esse material a uma lógica de linearidade ou causalidade, mas ao mesmo tempo oferecendo um mínimo de moldura, ou de uma lógica poética (a criação de uma ficção)?

Vamos começar com algumas considerações iniciais que se referem ao belo, constelando elementos da clínica e da estética. A partir dessas considerações, estudaremos alguns casos pelo aspecto da instauração de uma gramática cênica própria. Convocaremos essas experiências para investigar como as particularidades, singularidades e idiossincrasias de cada pessoa podem ser legitimadas em linguagem artística. Por fim, vamos refletir como esses processos de criação podem ser gestos micropolíticos, estéticos e existenciais; como essa poética própria pode nos abrir a outras lógicas e outras configurações de mundo, e de que modo essa abertura modifica nossa sensibilidade.

Em uma escala mínima, há uma inquietude causada pelas imagens descritas no primeiro parágrafo. Algo que atrai e chama nossa atenção. A sequência de imagens nos leva a perguntar "Como percebemos? O que percebemos? O que fazemos perceber? $\mathrm{E}$ o que, sobretudo, tornamos invisível?"3.

O rapto de nossa atenção e afeto causado pelo inusitado está relacionado a uma ideia de beleza que parte do filósofo Alfred North Whitehead. Seu texto começa com a frase: "a beleza é a adaptação mútua de uma série de fatores na ocasião de uma experiência" ${ }^{4}$. (Quando Whitehead fala

\footnotetext{
${ }^{2}$ LAPOUJADE, David. As existências mínimas. São Paulo: Ed. N-1, 2017. p.59.

3 PELBART, Peter. Biblioteca de motins: leituras para incendiar o país. Palestra proferida na Flipei, 2019. Disponível em: <https://br.ivoox.com/es/peter-pal-pelbart-flipei-2019-audiosmp3_rf_38403388_1.html >. Acesso em: 11 maio 2015.

${ }^{4}$ WHITEHEAD, Alfred North. Adventures of Ideas. [S.I.]: The Free Press, 1967, tradução minha. p.252.
} 
de experiência, não se refere somente a experiência humana, podemos pensar, por exemplo, em um pôr do sol como exemplo de experiência.) Mais adiante em seu texto, explica que há um tipo de beleza que não é apaziguada, em que esses fatores discordam entre si, e que esse tipo de beleza discordante seria a mais valiosa, pois está a serviço da vida em sua capacidade de reinvenção e de surpresa, ao contrário de outro tipo, uma forma menor, sem contrastes, que ele chama de anestésica e que estaria mais ligada a um movimento de repetição ${ }^{5}$.

Deleuze desdobra essa reflexão sobre as camadas discordantes quando mostra que essa capacidade de reinvenção também está ligada a um certo desmanche e a uma "dinamização da nossa inteireza"6. Em sua análise dos filmes do diretor Hans-Jürgen Syberberg, ele descreve que a linguagem criada por Syberberg é feita de vetores discordantes que não se apaziguam entre si as camadas "sonora e a visual, entram em relações complexas sem subordinação nem mesmo comensurabilidade" ${ }^{7}$ - ou nos quais o visual e 0 sonoro não reconstituem um todo, mas entram numa relação "irracional" segundo duas direções assimétricas.

Em seus filmes, há um "caráter não hierárquico e não causal" ${ }^{8}$ entre as informações: a fala vai numa direção e a imagem vai em outra, e elas não convergem. A fala não explica a imagem, e a imagem não é uma ilustração do que é dito. Para Deleuze, a desvinculação da imagem e do movimento "liberta outras forças que a linguagem [...] mantinha subordinadas"9. Essa discrepância entre o que se vê e o que se ouve, ou entre diferentes planos constituintes de uma obra artística, obriga-nos ao deslocamento da convergência do senso comum, assim como ao distanciamento de uma ideia harmônica de beleza. Para Deleuze, é da ordem do contemporâneo esse esgarçamento da sensibilidade, no qual "as situações já não se prolongam em ação ou reação"10, e a nossa apreensão dos fenômenos é feita de diferentes direções, não convergentes. Se essa discrepância entre os elementos, por um lado,

\footnotetext{
${ }^{5}$ Ibidem.

${ }^{6}$ Termo sugerido por Peter Pál Pelbart durante o exame de qualificação desta dissertação.

${ }^{7}$ DELEUZE, Gilles. A imagem-tempo: cinema 2. Brasiliense, 2005. p.315.

${ }^{8}$ Ibidem, p.320.

9 Ibidem, p.314.

${ }^{10}$ Ibidem, p.324.
} 
evidencia o desmanche de uma suposta coerência (de mundo, de pessoa, de enredo, de personagem), por outro, pode nos conduzir a algo diferente do conhecido ou instituído. A função poética pode "desestabilizar a trama das redundâncias dominantes, a organização do 'já classificado', ou, se preferirmos, a ordem do clássico"11.

Se o conceito de beleza discordante de Whitehead nos ajuda na investigação dos materiais criativos que surgem em nossos processos, a divergência entre som e imagem que Deleuze descreve nos serve para pensar no modo com que os diferentes elementos de uma gramática cênica podem participar da criação de um espetáculo. Para Deleuze,

Uma das originalidades, porém, de Syberberg está em armar um vasto espaço de informação, como um espaço complexo, heterogêneo, anárquico, onde estão lado a lado o trivial e o cultural, o público e o privado, o histórico e o anedótico, o imaginário e o real, e ora, do lado da fala, os discursos, os comentários, os depoimentos familiares ou ancilares, ora, do lado da vista, os meios existentes, ou que já não existem, as gravuras, os planos e projetos, as visões com as vidências, tudo se valendo e formando uma rede, sob relações que nunca são de causalidade ${ }^{12}$.

Nas relações entre os diversos elementos que compõem nossas heterogeneidades (existenciais e estéticas), há reinvenção e novas possibilidades. Todavia, para que elas aconteçam, é preciso trazer à tona também sua dimensão de anarquia e colisão ${ }^{13}$.

\section{Lembrar é diferente de acontecer}

É importante ressaltar que, em todos os casos descritos, são feitas tentativas de leituras, aproximações de sentidos. A cena não cabe nunca na sua descrição, assim como seus efeitos, que são múltiplos e variam de pessoa a pessoa. Para nossa reflexão, podemos trazer alguns elementos para levantar pistas das cenas que vão sendo criadas. Mas a experiência que está no texto, às vezes mais ou menos desenvolvida, vai além da descrição da sala de ensaio, das decisões que tomei, dos arranjos coletivos e das experiências

\footnotetext{
${ }^{11}$ GUATTARI, Felix. Caosmose. São Paulo: Editora 34, 1992. p.32.

12 DELEUZE, 2005. p.319.

${ }^{13}$ Agradeço ao Peter Pal Pélbart essas considerações, que ele trouxe na minha qualificação, sobre as camadas divergentes a partir dos estudos de Deleuze sobre Syberberg.
} 
cênicas, micropolíticas e existenciais que aconteceram. Há um descompasso na tradução de uma experiência da cena em um texto. A partir daí algo novo pode se instaurar: a descrição da cena é uma outra coisa, afinal, "lembrar é diferente de acontecer" ${ }^{14}$.

\section{Tatear junto}

No início de um dos encontros do MAM, as pessoas ainda estavam chegando e as atividades não haviam começado, quando uma participante quis cantar uma música. Quando ela acabou, perguntei se mais alguém queria cantar, e Ana fez um aceno mínimo com a mão. Ana, que frequenta nossos encontros desde o início do curso de performance, em 2011, é pequena e delicada, quase nunca fala, e quando o faz é com um fiapo de voz. Como sei que ela gosta muito do grupo Abba, me aproximei dela e acho que ouvi bem baixinho a melodia da música Dancing Queen. Acompanhei a melodia de dentro daquele registro sutil, e outras pessoas se juntaram. Ana cantava junto com sua voz praticamente inaudível, o que fazia com que todas nós tivéssemos que cantar nesse quase não volume. Em determinado momento, ela começou a fazer uma espécie de coreografia com as mãos. O contraste entre a energia dessa música (que é bem conhecida das pessoas e parece querer explodir dentro da delicadeza das vozes e da coreografia) e o jeito particularíssimo dela se colocar na cena - e no mundo - fazia com que a cena fosse bela, tivesse uma potência suave e explosiva ao mesmo tempo.

A beleza própria e enigmática desse momento poderia ser lida como 0 tipo de beleza discordante de que Whitehead nos fala. Os elementos aqui entram em discórdia, uma espécie de curto-circuito, mas ainda assim, e talvez por causa disso, criam uma gramática própria e particular. 1. Pela figura dela que é enigmática por natureza, ou fora do comum; um corpo que não traz em si uma jurisprudência de como observá-lo ou do que esperar dele - pelo contrário, pela exclusão e pela invisibilidade a que são submetidos esses corpos, e por serem diferentes, geralmente há um preconceito achatador em

\footnotetext{
${ }^{14}$ Fala de Olivia Lerner. Durante nossa convivência nos encontros desde o início do curso, há certos momentos de sua vida em que temas e frases são por ela repetidos constantemente como leitmotiv existenciais, assim como cada um de nós também temos nossos "temas", recorrentes e que, dependendo da pessoa e do contexto, podem ficar mais ou menos aparentes.
} 
relação a eles -, o que já cria uma curiosidade. 2. Pelo modo sutil desse corpo cantar uma música geralmente explosiva e energética, ligada a apoteoses de canto e dança, um sucesso em festas de casamento e formaturas. Aqui esse canto é quase sussurrado e, aos poucos, é somado a outros corpos que se juntam, tentam se colocar também nesse registo e compõem como que um coro de vulnerabilidades. 3. Pela expressividade de sua coreografia com as mãos e sua expressão de deleite enquanto participava desse gesto; aqui, novamente, há o fracasso em descrever esse tipo de situação, transpondo a potência de um acontecimento para um texto.

O jeito dela, ou o seu modo de existência, afetou o nosso, produziu um acontecimento inesperado: tanto para as pessoas, na experimentação sonorarelacional, quanto para ela, que parecia surpresa e feliz de ver outras pessoas participando de sua cena. Se por um lado houve um tanto de imprevisibilidade e transformação coletiva, ao mesmo tempo não é possível saber se ela inicialmente realmente estava cantando Dancing Queen ou eu cantei junto a partir de uma imaginação, de um dado que conhecia sobre ela. É muito tênue o equilíbrio na convivência com um não saber, com um tatear e experimentar junto, que é diferente de impor ou deduzir. Esse tatear junto é o que guia muitas vezes a relação nos encontros: há uma tentativa constante de deixar espaço para uma experimentação dos ritmos do outro, de suas possibilidades, de seus jeitos de entender pelas palavras, pelo corpo, ou mesmo pela presença compartilhada.

No início da aula, foi criado um espaço de indeterminação, no qual havia uma atmosfera que acolheu o imprevisto. O encontro não havia começado, e ao mesmo tempo havia começado. Essa indeterminação é importante para que, além das proposições que eu trago, também surjam manifestações e gestos do coletivo. Esses gestos também são feitos de silêncios, de ações estranhas e/ou belas, de clichês, de perguntas. A epifania às vezes acontece, como o surgimento dessa cena de Ana, mas aprendi que são igualmente importantes os momentos de silêncio. Os momentos em que nada acontece, sem que esse nada-acontecer seja tapado em nome de algum ideal de produtividade, clínico ou estético.

Em inglês há uma palavra, awe, que tem vários significados e não há um equivalente em português. Essa palavra pode significar maravilhamento, terror, 
arrebatamento, epifania, e se encaixa na zona fronteiriça que certos acontecimentos podem provocar, que oscila entre 0 maravilhoso e 0 aterrorizante. O afeto e a inquietação que a palavra traz convocam a uma renegociação dos sentidos para quem participa de um acontecimento que produz esse estado. Nosso caso seguinte pode ser analisado a partir de alguns elementos: a intensidade não classificável da palavra awe, o conceito de beleza discordante descrito anteriormente e a ideia espinosana de encontros que ampliam nossa potência de vida.

Estamos no espetáculo Silêncios, moléculas, dinossauros, criado junto aos participantes da ONG Ser em Cena. A plateia acabou de ver um grupo de pessoas enumerar diversos tipos de listas, por exemplo: lista dos bens do Olimpo, dos guarda-chuvas perdidos, das coisas que me fazem virar o olho, das fotos que eu não tirei, dez animais mais perigosos do mundo, das desgraças de 2017, dos filmes que eu dormi no meio, dos tipos de fenda no tempo e no espaço. A partir de um determinado momento, os atores se juntam e a cena vira uma polifonia indistinta, até que silenciam repentinamente e podemos ouvir uma melodia. As pessoas vão embora e permanece um ator tocando essa melodia em um ukulele (pequeno violão havaiano). Entram então Léo e Evelyn, Léo na cadeira de rodas, Evelyn entra com uma cadeira na mão. Se posicionam sentados no meio do palco e começam a cantar uma música. $A$ música lembra um folk, Evelyn começa a cantar, e depois Léo a acompanha com improvisos vocais. Em um terceiro momento, ele faz um solo com seus improvisos e é Evelyn quem o acompanha. Léo não fala palavras em línguas "oficiais", mas cria sua própria prosódia e, assim como Evelyn, tem um timing musical e uma noção de ritmo bem apurados, o que faz com que seja interessante o jogo entre estrutura e improviso da dupla. Além do ukulele, outros atores entram e tocam violoncelo e percussão, compondo uma espécie de conjunto ao fundo do palco. Há outro aspecto que faz com que a cena ganhe outras dimensões: Léo teve um tumor no cérebro e não tem uma parte da cabeça. Esse dado é relevante, pois à primeira vista sua aparência causa um estranhamento, e um pouco depois essa impressão é desfeita, uma vez que Léo é carismático, doce, divertido e gosta de interagir com pessoas. É engraçado como ele mistura partes de palavras com outros sons, mantém a melodia de uma conversa e está muito à vontade com seu jeito: isso costuma 
cativar quem está perto e ajuda a passar pelo estágio inicial da surpresa. Então, no meio do palco, temos os dois sentados cantando a música com o conjunto atrás tocando os instrumentos. A cena cria esse misto de surpresa, encantamento e desconcerto, graças aos elementos que a compõem e pelo modo com que eles são encadeados. Sem receita ou método, nesse caso especifico a cena funciona de modo potente: amplia nossa capacidade de ver a beleza, desloca alguns lugares fixos geralmente reservados ao que é belo, e afasta a invisibilidade e a visão paternalista a que alguns corpos ficam restritos. A cena é ao mesmo tempo delicada e estranha, engraçada e poética, e causa um embaralhamento dos sentidos.

Esses dois casos, de Ana e de Léo, cada um à sua maneira, instauram uma poética própria por suas particularidades em criar e por seus modos de existência. Ambas as cenas instauram outra possibilidade de ver e se afetar, que tem a ver com uma potência da vulnerabilidade. Ambos lidam com a música e instauram a beleza por meio de elementos discordantes: os contrastes entre sutileza (a suavidade, a delicadeza e a imprevisibilidade de suas gramáticas corporais e das cenas criadas) e exacerbação (no caso de Ana com a explosividade subterrânea da música, uma ausência presente, e com Léo, com a força e a surpresa de seus improvisos vocais e da primeira impressão de sua imagem, que foge dos padrões não somente do que é belo, mas do que é comum).

Dialogando novamente com as ideias de Whitehead, além da beleza das cenas formadas de elementos discordantes, como vimos, esses exemplos podem nos ajudar a repensar conceitos como harmonia e perfeição: as cenas só aconteceram com essa potência pois eram feitas desse modo e com essas pessoas, constituindo um todo específico na composição de suas imperfeições.

Para Whitehead, "mesmo a discórdia pode ser preferível a uma sensação de lenta recaída na anestesia geral, ou na domesticação que é seu prelúdio. Um baixo nível de perfeição está classificado abaixo da Imperfeição com maior objetivo" ${ }^{15}$. A coreografia singular das mãos e os volumes baixos e imperfeitos da música de Ana, o improvisar que flerta com palavras mas não

\footnotetext{
${ }^{15}$ WHITEHEAD, 1967, tradução minha, p.263.
} 
chega a formá-las de Léo, e sua figura também imperfeita que evoca estranhamento e carisma, promovem curiosidade e abertura.

Whitehead continua e dá exemplos de uma arte que, para ele, teria o valor mais alto: seria uma arte em que a individualidade dos detalhes não se perde no todo da experiência, não haveria um apaziguamento dos contrastes em detrimento de um ou de outro aspecto que causam contraposição, mas ambos os elementos discordantes existindo em suas intensidades. Mais adiante no texto, o autor explicita essa relação do todo com as partes. $O$ tipo de arte na qual ele está mais interessado é feito de intensidades de partes que reivindicam, cada uma delas, sua individualidade separada ao mesmo tempo que compõem a obra ${ }^{16 .}$

Tanto no caso de Ana como no de Léo, não é possível esquecer quem está cantando e de que modo, e ao mesmo tempo as suas idiossincrasias são indispensáveis para a performance.

Uma das contribuições de Whitehead para pensarmos esses casos é que o autor nos mostra que a beleza discordante também é uma ética, convidando-nos a pensar em outros tipos de beleza e mostrando que "o conceito de completa contemplação passiva abstraída da ação e de um propósito é uma enorme falácia" ${ }^{17}$.

Essa percepção tem a ver com abrir espaços para a indeterminação e o inesperado. É da ordem do encontro, de duas intensidades que se afetam e alguma coisa acontece, se transforma. A beleza discordante desses casos estudados está relacionada à estética, mas também à visão destes corpos em uma cena e ao modo com que ela acontece. Que corpos são considerados artísticos, quais são considerados aptos e como essa noção de quem é apto ou desejável de se ver (em cena ou não) está vinculada a formas de valoração. Rever algumas noções de beleza, harmonia, técnica, eficiência, precariedade e limites pode nos ajudar a repensar esses valores.

Deleuze nos ajuda a entender que modos de ver seriam possíveis nessa outra configuração: quando criamos ou assistimos uma cena como a de Ana ou

\footnotetext{
16 "A arte, no seu auge, exemplifica a doutrina metafísica do entrecruzamento do absoluto e do relativo. Na obra de arte, o relativo se torna a harmonia da composição, e o absoluto é a reivindicação da individualidade separada promovida por fatores componentes" (WHITEHEAD, 1967, tradução minha, p.264).

${ }^{17}$ Ibidem, tradução minha, p.264.
} 
de Léo, percebemos que "as situações já não se prolongam em ação ou reação". Em cenas como essas, em que são deslocados (ou demolidos) alguns pressupostos instituídos de beleza ou harmonia, "o problema do espectador torna-se o que há para se ver na imagem", e não mais "o que veremos na próxima imagem"18.

Fotografia 17-Performance 8 léguas para Fibo- Igual Diferente- Mam, 2014

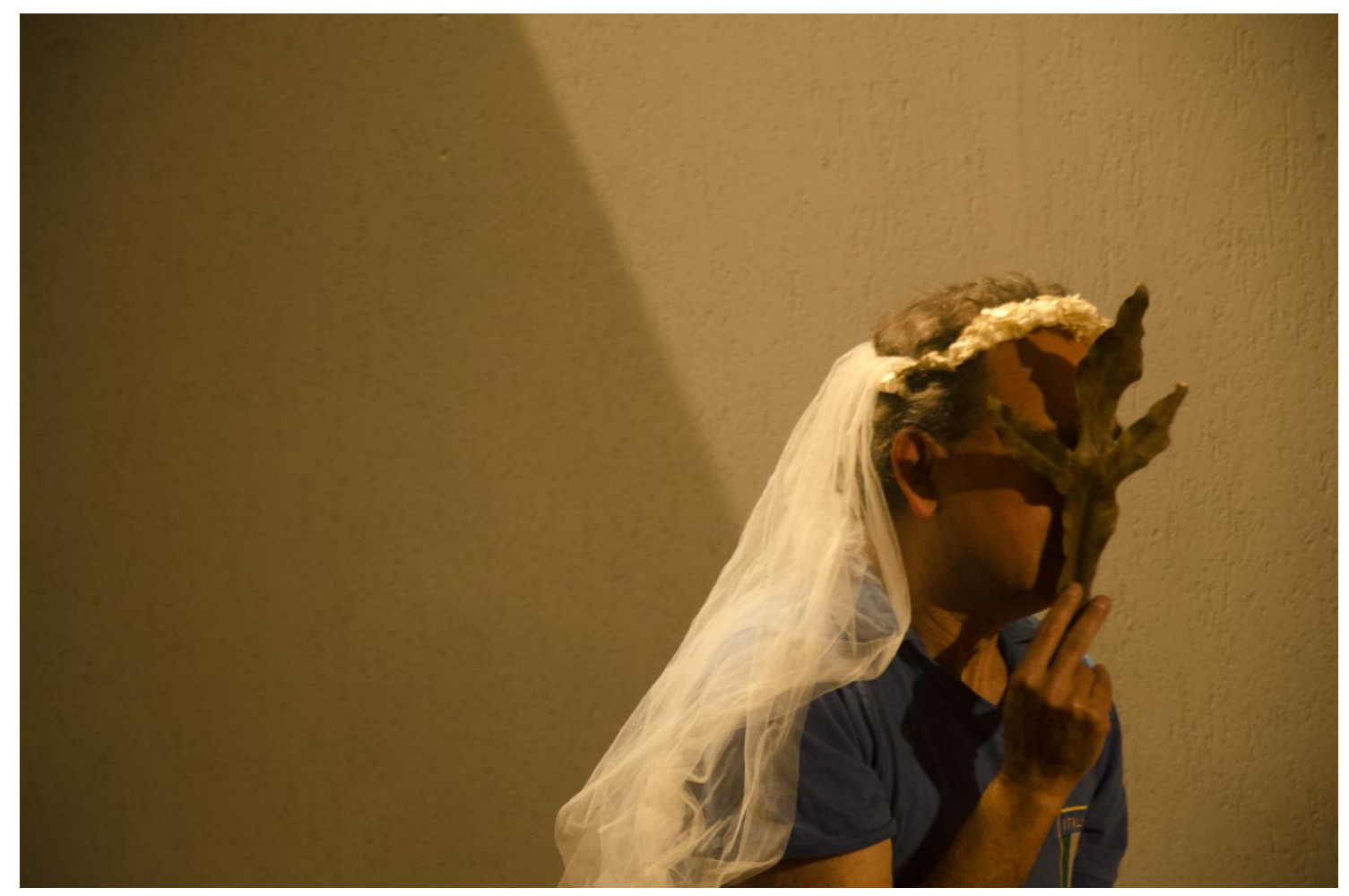

Paulo Dersu, performer. Foto: Karina Bacci

\section{A cantora fantasma}

Procuro não conhecer os diagnósticos nem os prontuários médicos antes de conhecer as pessoas e, na maioria das vezes, também não olho depois, de modo que a descoberta dos limites e das potencialidades de cada pessoa acontece na sala de ensaio, nos encontros e na relação. No caso descrito anteriormente, Ana tem a Síndrome de Rubinstein-Taybi. Só descobri o nome clínico dessa síndrome no momento de colocar na presente pesquisa, e me questiono até que ponto estas são informações relevantes em nossos processos criativos. Se por um lado não me influencio com a pré-formatação

\footnotetext{
${ }^{18}$ DELEUZE, 2005, p.323.
} 
dos discursos médicos, por outro, esse desconhecimento às vezes causa dificuldade de comunicação, e tenho que descobrir de um modo tentativa-eerro as especificidades de cada um e de cada uma ${ }^{19}$.

Durante a criação do espetáculo Silêncios, moléculas, dinossauros ${ }^{20}$, em um encontro propus ao grupo que cada um fizesse um som, uma pessoa por vez. Em seguida, propus que fizéssemos uma rodada com som de fantasma ou uma aparição fantasmagórica. Cada pessoa emitia um som que durava uma expiração, que poderia ser "uuuuu", ou "uhuhuhuhuhu", ou então "000000o". Há duas pessoas no grupo que falam, respectivamente, "faaaaaaa" e "oioioioi", esses sons são todo o léxico atual de cada uma delas, podendo variar a intensidade, a intenção ou o modo de pronunciar. Aqui também é inevitável falar de uma parcela de incomunicabilidade da pesquisa. Tentar descrever esses processos faz com que este texto também seja afásico de algum modo.

Experimentamos o mesmo exercício também em duplas, trios ou todos ao mesmo tempo. Surgiram outros sons interessantes que ficaram guardados no inventório ${ }^{21}$.

Chegou ao grupo uma senhora elegante e animada que a equipe havia me informado chamar-se Sophie. Ela gosta muito de fazer as cenas e participar das atividades, e seu modo de participação atravessa qualquer ordem possível. Entra nos momentos em que deseja, a maioria das vezes fazendo improvisações com a voz, e fica também o tempo que deseja nessas improvisações.

Ela tem Afasia Progressiva Primaria (APP), uma doença degenerativa que afeta a linguagem e a compreensão. Aos poucos, fui percebendo que, geralmente, pessoas que têm APP apresentam outra noção de tempo, e justamente por causa disso podem produzir cenas surpreendentes (e que não acabam nunca!), em geral precisando de algum dispositivo para ajudá-las a finalizá-las. Nos exercícios em que os participantes estão em círculo, é comum

\footnotetext{
19 Não pretendo minimizar a importância da equipe terapêutica que é essencial nesses processos e cuida do aspecto clínico, assim como o procedimento relatado refere-se aos primeiros encontros, quando eu formo o meu "diagnóstico", e não é uma regra geral. Por exemplo, alguns casos específicos ou mais graves (como pessoas que têm um risco de queda ou de convulsão) são compartilhados entre a equipe para que possamos nos preparar para lidar com a pessoa.

${ }^{20}$ Com a ONG Ser em Cena, que atende pessoas com afasia.

${ }^{21}$ Descrito no capítulo anterior.
} 
que Sophie fique improvisando uma espécie de canto-murmúrio, às vezes acompanhado de dança. Mesmo quando percebe que está na vez de outra pessoa, ela acompanha com a voz. Sempre que conversa com alguém, é uma espécie de murmúrio de vogais, que para ela é perfeitamente compreensível e para nós não, de modo que fica um pouco brava se falamos que não estamos entendendo. É um desafio enorme se comunicar com ela mantendo algum tipo de troca sem se esquivar e nem parar a atividade coletiva para tentar decifrá-la. Muitas vezes, ela se aproxima de mim e fala bastante, como que me informando de coisas ou reclamando de outras. Nessas ocasiões, procuro entender o tom do que ela fala e fazer algum tipo de troca, falar sobre a cena, ou sobre o processo, ou o que estamos fazendo e como é sua participação. Às vezes parece entender, outras não, e continuamos assim, com nossa comunicação entrecortada, mas com um prazer visível que ela tem de estar em grupo participando dos encontros, o que para mim justifica sua presença ali.

Nesses trabalhos, há a questão de como lidar com a compreensão que cada pessoa tem: há algumas que não entendem exatamente ou mesmo quase nada do que falo, ou das indicações que dou, mas pegam uma atmosfera, um ambiente, se apropriam do seu jeito singular daquela experiência. Como elaborar encontros em que seja possível que todos os participantes estejam implicados, sem que seja abstrato demais para os que não têm uma apropriação mais genérica das indicações, nem fácil demais para os que podem lidar com indicações mais precisas e complexas?

Durante os encontros e em conversas com Fátima Monteiro, a psicóloga que acompanha as atividades da ONG, percebemos que Sophie pode entender melhor se falarmos bem na frente dela - não com um enunciado para o grupo todo - e também com a ajuda de gestos.

O exercício do fantasma acabou virando uma cena. Como as improvisações de Sophie têm variações vocais inusitadas e uma duração mais longa, imaginamos para ela uma cena de cantora que se encaixasse melhor com seu jeito.

Expliquei-Ihe que faríamos sua cena separadamente e me pareceu que ela compreendera. Na hora da cena do fantasma, todos em círculo, pedi que cada um fizesse seu som e pulei Sophie, que há algum tempo não consegue mais falar palavras inteligíveis (e não tenho lembrança de ter alguma vez 
entendido alguma palavra dela). No entanto, quem estava a seu lado ouviu claramente ela falar, ao perceber que foi pulada, "vou embora!", bem brava, levantar-se e sair. Corri atrás dela, expliquei, agora bem perto, que ela tinha uma cena separada, a cena da cantora, e a dos fantasmas ela não participaria porque ficaria muito parecido com a cena da cantora. Não sei o quanto e mesmo se ela entendeu. Voltamos e ensaiamos a cena da cantora, o que a deixou mais calma, mas não totalmente convencida. Seria inviável ter que explicar tudo isso a cada ensaio.

Novamente em conversa com Fátima, pensamos que poderia funcionar a utilização de um objeto que espacialmente a fizesse perceber o momento de entrar no foco. Testei uma echarpe, o que resolveu a percepção de quando seria sua cena, mas ainda assim ela se dirigia para diferentes direções. Então testamos com um ator segurando uma moldura, como uma espécie de camareiro/serviçal da cantora. O camareiro entra em cena com ela, para no meio do palco, Sophie, emoldurada, faz seu show e eles saem. Esse dispositivo funcionou muito bem justamente por não funcionar muito bem: estabeleceu-se um jogo entre eles no qual ela percebe a moldura, mas às vezes escapa, desobedece, muda a direção, e então o camareiro tem que ir atrás dela e emoldurá-la novamente, ou ela volta para a moldura. Além do colapso do enquadramento da cantora, essa cena também remete a um quadro mal-assombrado, uma diva, ou cantora de ópera. Essas imagens criam molduras ficcionais e permitem a imprevisibilidade das suas improvisações vocais e corporais dentro desse contexto.

No final, Sophie acabou sendo incorporada na cena dos fantasmas. Cayo Eduardo, que participava do grupo e também era assistente da ONG, criou a partir da nossa improvisação um texto de entrevista de empregos para fantasmas. Entre outras exigências para o emprego, estão dois séculos de experiência, sem férias, sem remuneração e sem décimo terceiro (é inevitável o surgimento dos atravessamentos estéticos-políticos do contexto da época, com as novas leis trabalhistas a que as pessoas foram submetidas naquele momento em 2019 no Brasil). Após cada candidato mostrar sua expertise em sons assombrosos, a moça do $\mathrm{RH}$ anuncia a próxima candidata: esta é a cena da Sophie incluída dentro da cena dos fantasmas. 
O que no início exigiu que nos deslocássemos e experimentássemos possibilidades de acolhimento e criação, que incluíam o ruído, o atravessamento e uma dose de caos, acabou se transformando numa cena única e bela, justamente pelo modo de expressão da atriz em questão, que propõe um outro jeito de experimentar a voz em cena, feito de cantos, pausas, risadas e falas, costurados de um modo que só ela teria possibilidade de fazer.

\section{O roubo dos pertences da cantora fantasma}

A um mês da estreia, fui informada que a casa de Sophie foi roubada, ela e o marido ficaram traumatizados e se mudaram de cidade da noite para 0 dia. Depois do susto, de saber que estava tudo bem com ela e do desapontamento de perdermos nossa cantora, começamos a imaginar possibilidades.

Em uma conversa com a equipe, algumas pessoas sugeriram outras mulheres: tinha que ser uma mulher, a cena da cantora não poderia virar uma cena de cantor. Algumas mulheres no grupo participam da aula de coral, e tem uma aluna que faz improvisações vocais de jazz muito bem executadas.

A conversa nos trouxe algumas reflexões. Não poderíamos simplesmente chamar alguém que cantasse bem de acordo com os parâmetros musicais usuais. Essa pergunta nos trouxe outra: o que é cantar bem? Quais vozes e afinações podemos ver em cena? A força de Sophie está justamente no seu desencaixe, no jeito que ela canta, uma espécie de Meredith Monk ${ }^{22}$ menos sisuda, que se diverte, sorri, mistura trechos de ópera, risadas, samba, e o que mais vier à sua cabeça no momento. Diferentemente de Léo, que estudamos no caso anterior, que canta dentro de um ritmo e de uma mesma paleta de notas, ela tem uma musicalidade que escapa de contornos ou escalas musicais.

Percebemos que seria uma substituição impraticável. Não seria possível nem desejável colocar alguém imitando a Sophie. O critério para se achar essa nova cantora era de outra ordem. Aqui vou fazer um pequeno desvio para pensar sobre esse critério.

\footnotetext{
${ }^{22}$ Meredith Monk é uma cantora, performer e coreógrafa conhecida, entre outras coisas, por explorar as possibilidades expressivas da voz e pelas experiências vocais em que utiliza a materialidade da voz como suporte.
} 
Fiz um curso de escrita e desenho em 2015 com o artista Lourenço Mutarelli, e em suas aulas ele explica que um dos objetivos é desenhar errado. Que a pior coisa que pode acontecer a uma criança é ensiná-la a desenhar o Mickey ou o Snoopy. Com esse gesto, mata-se a espontaneidade de traço e de estilo de alguém logo de início, e se prepara aquela pessoa para ser um copiador do estilo alheio. Lourenço teve seus anos de aprendizado instrumental, tem um grande domínio nas técnicas do desenho, da pintura e da literatura, e sabe que a técnica é importante na formação de uma pessoa (seja ela artista ou qualquer outra profissão), mas ele também sabe como o excesso de formatação pode ser prejudicial. Para nossa pesquisa, vamos recortar nesse equilíbrio entre técnica e espontaneidade - a importância do que poderia ser chamado de desaprendizagem, que pode acontecer de muitos modos. Pode ser alguém que questiona determinada linguagem e busca outros modos de expressão, ou pode ser alguém que, por algum acontecimento externo, tem seu funcionamento colapsado e precisa inventar outros modos de existência. Se pensarmos bem, alguns colapsos são mais aparentes, mas sempre que existe uma mudança - de linguagem, de comportamento -, ela está ligada a algo que não funciona mais, que não cabe, e que precisa ser reinventado.

$\mathrm{Na}$ arte, assim como na ciência, a invenção cria novas coordenadas, e o que era errado em determinado contexto pode vir a ser criação em outro. É preciso um desfuncionamento de algo para que outra coisa surja. No caso de pessoas com afasia ou APP, há um desfuncionamento que produz outros tipos de possibilidades existenciais-criativas - as duas coisas estão entrelaçadas, pois às vezes temos que ser criativos para existir. $E$ isso não se refere somente a afasia ou psicoses, mas às crises, aos mundos que naufragam e demandam novas configurações.

Em relação à substituição da Sophie, esboçamos uma pequena lista de intuições, de candidatas a candidatas de fantasma. Nessa lista, tínhamos como critério na busca por uma nova cantora, encontrar alguém que cantasse errado. Não era um errado qualquer, mas que tivesse uma dose de imprevisibilidade e caos no canto, pois assim conseguiríamos manter o espírito da cena, mesmo que a voz e as sonoridades fossem completamente diferentes. Queríamos colocar em cena alguém que produzisse uma diferença em relação ao senso 
comum do que se imagina ser uma apresentação de uma cantora. Precisávamos de uma cantora desvirtuosa.

\section{Orna e as palavras}

Orna, uma das atrizes da ONG Ser em Cena, é uma senhora de aproximadamente 60 anos que tem em suas particularidades, assimetrias e desobediências que pedem respostas criativas e relacionais minhas e do grupo, o que tem resultado em cenas singulares e em uma parceria fértil.

Ela faz um uso surpreendente e particular das palavras, com seu modo intenso. Vou relatar alguns momentos de nossos processos de criação que ajudam a compreender melhor como diferentes modos de existência podem ser instauradores de sintaxes cênicas.

A primeira cena que criamos juntas surgiu quando percebi que, nos encontros, ela frequentemente se expressa com um vocabulário de adjetivos, como "maravilhoso!", "magnífico!", "positivo!" etc., e tem uma voz forte que toma conta do ambiente quando exclama suas interjeições. Imaginamos uma cena a partir delas, ou seja, a cena se daria em relação a algo a que ela pudesse reagir; logo, ela seria a plateia. A partir dessa ideia, tivemos que achar um número para essa "plateia" (Orna) poder reagir, em vez do que seria mais comum: criarmos uma cena de apresentação e só depois pensarmos nos espectadores.

Outro ator da ONG, André, foi músico, e sempre que fazemos improvisações ele fica animado e simula estar tocando um piano, que varia de altura no espaço e às vezes se transforma em outros instrumentos. A partir disso, pensamos que poderia ser uma apresentação musical. Testamos várias possibilidades - um trio, várias pessoas, com instrumentos cenográficos - e optamos por ter somente ele em cena, simulando seu piano imaginário, que muda de lugar e depois vira contrabaixo sem que se possa ter o mínimo controle sobre isso. Nem é desejável ter esse controle, e esse aspecto também é importante: há uma parte que é descontrolada, ou improvisada dentro de um certo universo - são instrumentos e ele está tocando para um público -, e outra parte que precisa acontecer para que haja uma cena dentro de uma peça. Para isso precisamos fixar um início e um final, bem como um tempo aproximado de 
cena, o que não é possível com esse ator, pois sua variação de duração de uma cena pode ser infinita.

Fotografia 18 - Cena: A incrível orquestra de um homem só. Do outro lado do oceano - Ser em Cena, 2016

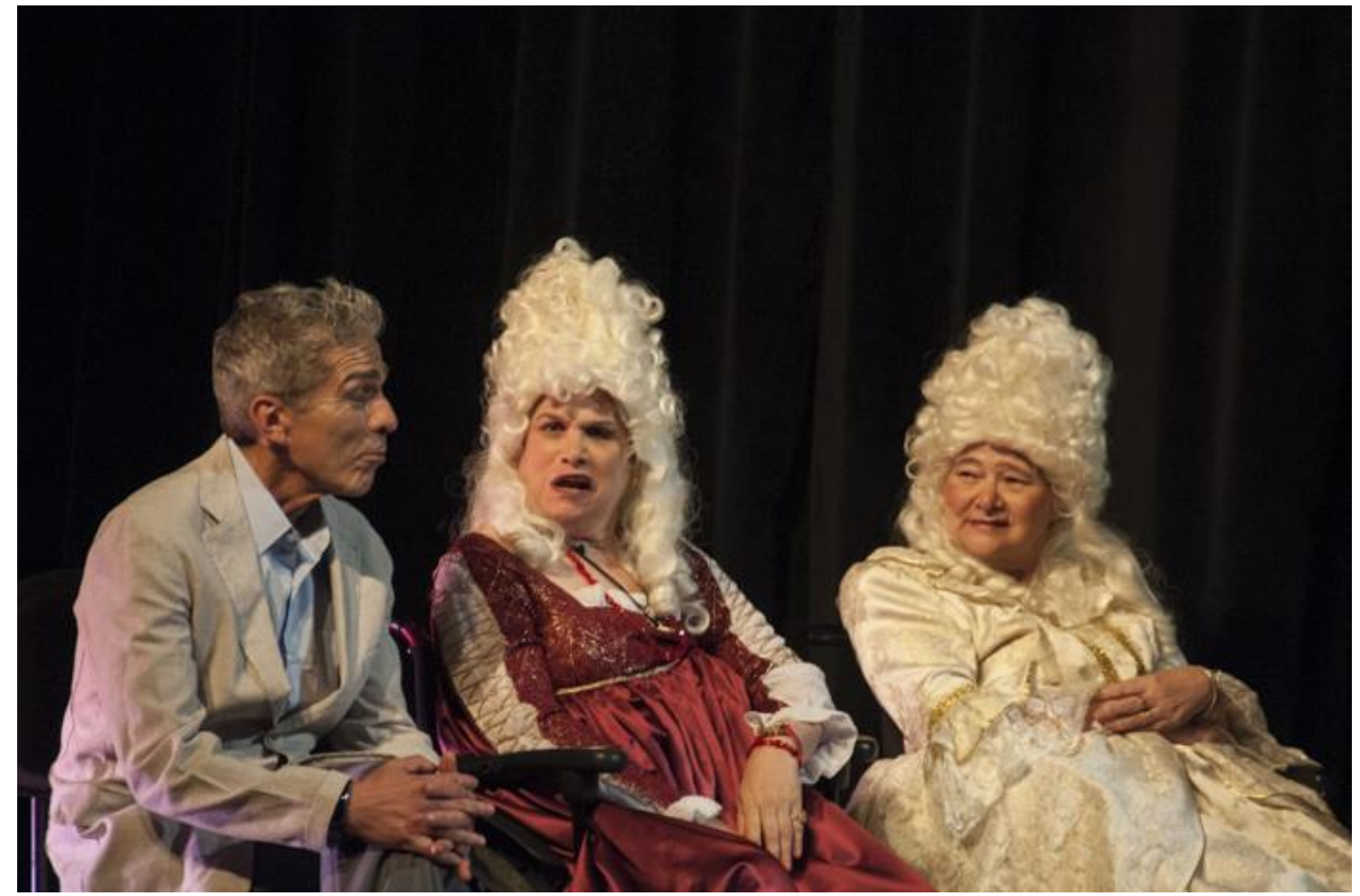

Carlos Augusto, Orna Winter e Antonese Sales. Foto: Luís Dávila/Vila Imagem.

Para poder dar uma solução, entra outro ator, Victor, que anuncia com pompa: "senhoras e senhores, com vocês, a incrível orquestra de um homem só!”. Victor também tem a Síndrome de Rubinstein-Taybi, a mesma do caso de Ana, mas são pessoas completamente diferentes. Assim como a afasia, as variações entre as pessoas que têm essa síndrome são imensas. A única coisa que se poderia dizer é que, assim como Ana, Victor tem um modo particular de se relacionar e de estar no mundo e na cena.

É importante ressaltar que a solução para a cena encontrada (a entrada de Victor como mestre de cerimônia), funciona como um desafio, uma construção formal que gera linguagem. Criamos a partir do que se apresenta: 0 que surge nos encontros é nosso vocabulário para a criação, em vez de ter um horizonte de expectativa a priori. Quando isso acontece, acabamos vendo um futuro do pretérito. Como em qualquer processo de criação, não queremos ficar reféns do que poderia ser. 
Além do tempo, há a questão do espaço: André entra seguindo Cayo (assistente citado no caso anterior), que o ajuda a se localizar no palco, pois André tem dificuldade de assimilar posições espaciais. Para resolver essa especificidade geográfica (quem nunca? Até hoje me perco em linha reta, e o Waze mudou minha vida), inventamos que Cayo poderia ser um maestro, o que tornou a cena mais interessante, pois os dois entram cheios de cerimônias - que tem a ver com andar devagar para que os dois possam compartilhar um mesmo ritmo -, um para em frente ao outro, ambos se aquecem, se espreguiçam, viram de frente e começam. O músico toca os seus instrumentos e o maestro rege, enquanto Orna exclama: "Maravilhoso! Magnífico! Excelente! Positivo!". E assim por diante.

A cena tem quase sempre o mesmo tempo, pois as interjeições da Orna começam em um momento especifico da música, quando já se teve algum tempo para se instaurar a relação do músico e do maestro com o público - e isso aconteceu sem minha intervenção e com uma precisão milimétrica por parte da Orna. Então, há uma partitura fixa - quando entram as pessoas, onde ficam, quando o público começa - e uma parte improvisada - quais instrumentos, como eles são tocados, quais exclamações e em que frequência, dependendo do que os atores desejam e querem fazer no momento da cena. $\mathrm{Na}$ criação dos nossos espetáculos, a dramaturgia é geralmente composta de partes mais roteirizadas, e também de momentos de liberdade para 0 desencaixe, a imprevisibilidade, o que quase não acontece.

Como encontrar um final? Aqui fico em dúvida entre a palavra encontrar ou criar. Ambas funcionariam. Nesses processos, quando estamos investigando e buscando a melhor forma, o momento em que um gesto é criado, em que uma cena funciona ou é justa, é ao mesmo tempo um momento de criação e de descoberta, ou encontro.

$O$ ator que faz a orquestra, apesar de ter ritmo e musicalidade com os diferentes instrumentos que simula, não tem a possibilidade de um fim: em todos os improvisos que fazemos, ele se estende até alguma coisa acontecer, portanto, não poderia ser ele a finalizar a cena. Também não seria possível escolher um dos adjetivos que Orna exclama, pois ela sempre os muda. Propus a ela que exclamasse as vogais: "A! E! I! O! U!", e essa seria a deixa para a orquestra terminar e agradecer o público, o que funcionou. Ela não 
consegue fixar um dos adjetivos, mas conseguiu fixar as vogais (que são bem diferentes desse universo) e o momento quase exato de dizê-las, em torno de dois minutos e quarenta e dois segundos depois do início da música.

Após essa exclamação, a orquestra e o maestro agradecem o público e saem, porém a música continua e aumenta: o ator que faz o mestre de cerimônias se empolga muito e começa a dançar, fica mais um minuto dançando para só então sair. Novamente, aqui uma constrição formal gerou a linguagem: a característica do ator que faz o mestre de cerimônias - no caso, sua dança peculiar - contribuiu para a ideia de uma orquestra que termina sua apresentação, mas o som continua (camadas divergentes entre som e imagem).

Durante os ensaios dessa cena, havia uma outra atriz, Antonese, que costumava sentar ao lado de Orna. Toda vez que Orna gritava com seu vozeirão um dos adjetivos, Antonese criava um duplo, o som vinha fraco, cheio de ar e a palavra ligeiramente diferente, um eco fantasma distorcido.

Por exemplo:

Orna: "Maravilhoso!".

Ouvimos com um delay o fiapo da outra voz, rouca e suave, de Antonese a seu lado: "Mavioso!".

Portanto, com o repertório de interjeições de Orna e sua dupla fantasmagórica, Antonese, a dança particular de Victor como mestre de cerimônia, André e sua incrível orquestra de um homem só on $^{23}$ o maestro Cayo e seus movimentos em diferentes alturas, temos exemplos de como diversas lógicas próprias de corpo, de ritmo, entendimento e desejo se combinam na criação de uma cena.

Cada uma dessas pessoas não se encaixa no corpo que normalmente pertence ao campo das artes, e a composição desses desencaixes produz linguagem. Essa composição não se dá de modo fluido e obediente, as palavras de Orna mudam completamente a cada vez, a caminhada de Victor mistura pompa e hesitação, assim como André e Cayo experimentam variadas direções espaciais. Todos esses elementos fazem com que a cena quase não aconteça a cada vez, e ao mesmo tempo aconteça com essa potência de

\footnotetext{
${ }^{23}$ Nome dado a cena, que fez parte do espetáculo Do outro lado do oceano, apresentado no teatro do Sesi e do Frei Caneca em 2016 e 2017.
} 
quase não acontecer. É preciso prever um tanto de imprevisibilidade nessa composição.

Fotografia 19 - Cena: A incrível orquestra de um homem só. Do outro lado do oceano - Ser em Cena, 2016

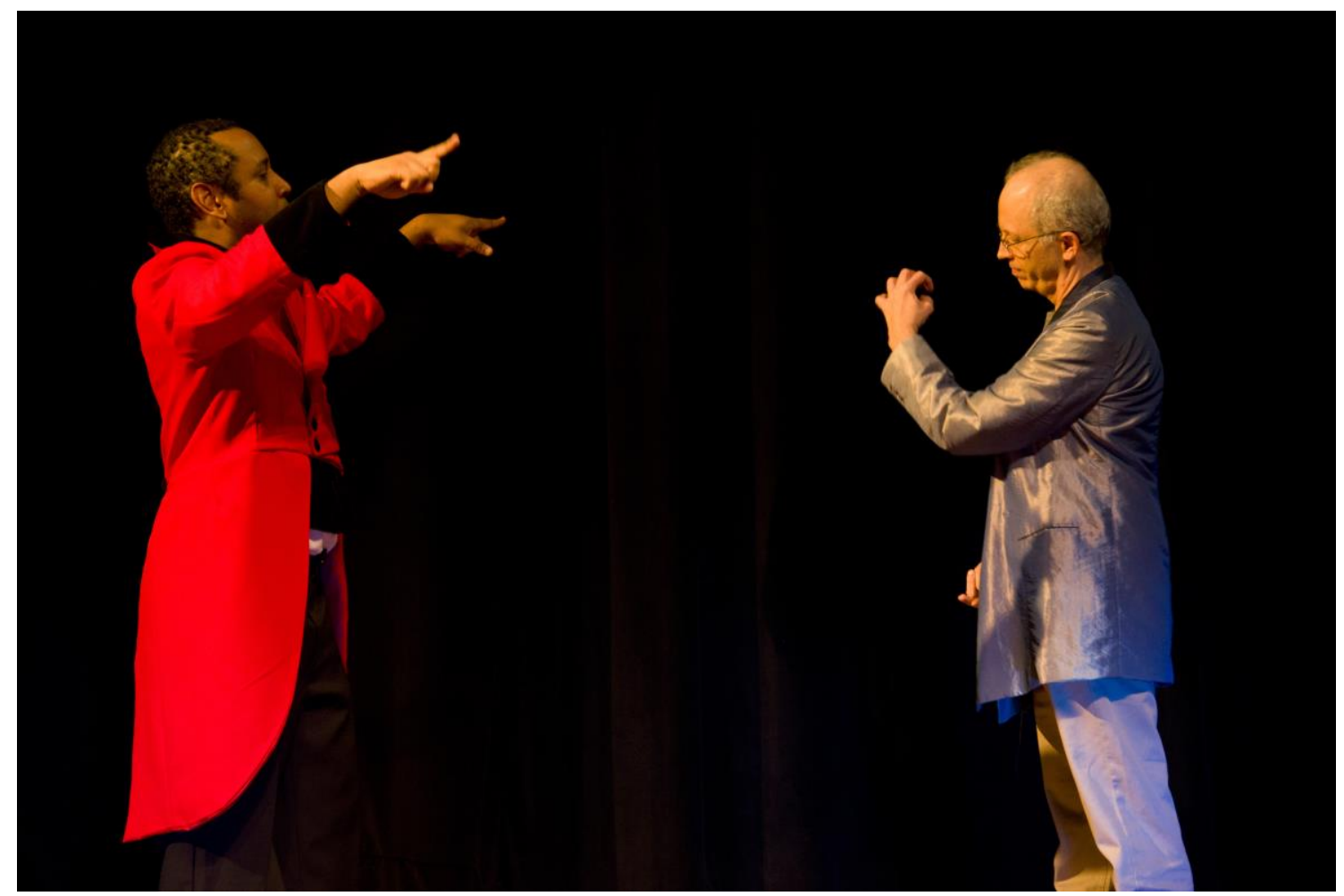

Cayo Eduardo e André Mariano. Foto: Karina Bacci.

Ao pensar nas sustentações que são necessárias para essa cena, lembro de quando Lapoujade escreve que "Souriau vê o artista, o filósofo ou o pensador como o advogado de existências fracas, todas essas existências que reivindicam existir de outro modo ou conquistar mais realidade" ${ }^{24}$, consideramos que a fraqueza a que ele se refere, assim como a reinvindicação de maior realidade ou outros modos de existência, está relacionada ao lugar que é designado para essas pessoas, de exclusão, silenciamento, invisibilidade. O gesto de criação artística, ao instaurar esses diferentes modos de existência, aumenta a potência de vida da obra artística e dos artistas criadores.

\footnotetext{
${ }^{24}$ LAPOUJADE, 2017, p.91.
} 


\section{As palavras dói, dói, dói}

No início de 2018, em uma conversa com a turma, Orna deu um depoimento em que se expressava com as palavras e os recursos que tinha: sinalizou dor; buscou ajuda de gestos com as mãos em determinadas partes do corpo; teve momentos de prazer e agradecimento; e, permeando tudo, havia sua procura pela palavra, embaralhando termos comuns e clichês que, misturados a essa urgência de precisar ou querer se comunicar, davam a essas palavras, ou escombros de palavras, uma potência surpreendente. Pedi que ela repetisse o que contou, o que fez de modo diferente, mas mantendo a intensidade da fala.

Disse-Ihe que achava sua fala importante, que tinha uma poética própria e inusitada, e que, se ela concordasse, gostaria de inventar uma cena com essa fala. Orna concordou e ficou feliz com a ideia.

Um porém: em alguns dos encontros subsequentes, pedia-lhe que improvisasse o que chamei de a cena das palavras, para ver como seriam as variações em diferentes dias e experimentar o que acontecia entre minhas indicações e suas falas. O tamanho variava muito, diferentemente da cena da orquestra do ano anterior, assim como o conteúdo variava dependendo de seu estado no dia (mas a beleza da cena se mantinha).

A seguir exemplos de quatro registros da cena das palavras:

Como é bom fazer amor

Quando a gente faz amor de verdade cada vez aumenta mais, é maravilhoso

As palavras (gesto de impedimento com a mão na boca) putaqueopariu

Ser mais inteiro

Ser mais independente

Ser mais embora de casa

As palavras... puxa vida

As palavras dói... dói... dói

(10 fev. 2017)

Por favor, positivo, puxa vida, puta merda

(17 mar. 2017)

Queria compreender as palavras todas iguais poder sentar... e esperar um pouquinho... pode esperar as palavras

as palavras dói

que nem a gente pode

sair de casa ser mais

alegria poder sentar

e pedir com carinho para 
compreender as parte mas

as palavras podem entender.

As palavras. As palavras.

Então dói.

Assim (gesto circular na cabeça em cima, no estômago)

Positivo.

Pra conseguir as palavras como é importante

como ser mais elegante

para conversar

todas vozes

para poder entender

ser mais alegria

ser mais elegante

como pode entender

amizade

eu eu eu e você

as palavras.

(7 abr. 2017)

as palavrinhas

como pode conseguir entender

começa quando a gente teve razões, teve razões

também conseguir ter momentos

definir

pensar em quanta gente quer entender

como você estava positivo

mas as palavras

as palavras dói... dói... dói

quisera deus

precisa compreender

há mais palavras todas

como quer dizer

por favor

mas as palavras, as palavras, as palavras dói... dói... dói

(3 maio 2019)

Em algumas dessas ocasiões, em determinado momento falava "obrigado senhor, obrigado". Pedi para ela falar o que quisesse, com duas indicações específicas: primeiro, não falar de deus. Expliquei que se ficasse agradecendo o senhor pareceria uma cena religiosa, o que reduziria muito o sentido. Ela sinalizou entender e concordar, mas na improvisação seguinte falou "obrigado senhor". Meu segundo e mais importante pedido era que ela mantivesse a frase final que falou a primeira vez: "as palavras dói... dói... dói”.

Não consegui que nenhum dos dois pedidos fosse atendido. Não sei se pela variação de seus estados dependendo do dia, ou se era mais fácil falar as vogais (da cena da orquestra descrita anteriormente), porque não tem nada a ver com o que veio antes ou o fato de ela estar com menos memória do que no 
ano anterior. O fato é que a cena variava bastante a cada dia, e tive que negociar comigo mesma: abdicava de excluir deus, mas a frase final precisava acontecer.

A solução foi deixar um celular com fone no ouvido dela, ligar para ela antes da cena e, quando eu achava que seria um momento propício para o final, falava as palavras no telefone. Com essa nova invenção do "ponto", tentei em alguns momentos relembrar certas frases específicas, mas atrapalhava seu fluxo e ela ficou rebelde, ignorando tudo o que eu falava. Resolvi voltar atrás e fiquei quieta durante o monólogo, com exceção da fala final, e desse modo funcionou.

Assim pudemos manter o caráter fragmentário e desencaixado de sua fala, que produz um outro tipo de encaixe e de léxico, e mantivemos as palavras finais que ela criara. Funcionei como um dispositivo de memória. É interessante perceber com um recurso tão antigo como o ponto, aqui, ganha outra dimensão, permitindo a Orna que recupere o encadeamento das suas próprias palavras.

Um dia, Orna apareceu com um boneco, se divertindo muito por tê-lo trazido e de mostrá-lo a todos. Ao ver o bebê grandalhão e descabelado, veiome a imagem de um ventríloquo (essas bonecas têm algo de criatura), e sugeri-lhe que ensaiássemos a cena. $O$ resultado foi engraçado, pois ela fazia uma voz bem diferente da dela quando falava como boneco. Experimentamos fazê-la ter uma personalidade diferente daquela da boneca.

As primeiras improvisações:

\author{
Ator: Oi tudo bem? \\ Orna: Tudo \\ Ator: Qual é o seu nome? \\ Orna: Orna Winter \\ Ator: Ah! E qual o nome dele? \\ Orna (com voz de boneco): Orna Winter Junior \\ Ator: Tudo bem Orna? \\ Orna: Maravilhoso! \\ Ator: $\mathrm{E}$ tudo bem com você? (Direcionado para o boneco) \\ Orna (com voz de boneco): Puta que o pariu!
}

Durante o processo, experimentamos com outra atriz no papel de boneco, Yasuko, que é mãe de um participante da ONG e acabou participando 
dos encontros e do espetáculo como atriz ${ }^{25}$. Aos poucos, fomos experimentando abolir a pessoa que pergunta, pois, apesar dessas perguntas produzirem uma graça imediata, quando deixamos para Orna administrar as falas dela e do boneco (Yasuko apenas movia os lábios), a cena cresceu em intensidade. Temos o modo particular com que Orna encadeia as palavras e alterna as diferentes vozes. Também as pausas em que triangulava com Yasuko e a plateia tornaram a cena singular, divertida e ao mesmo tempo enigmática.

Fotografia 20 - Cena: O duplo. Silêncios, moléculas, dinossauros - Ser em Cena, 2019

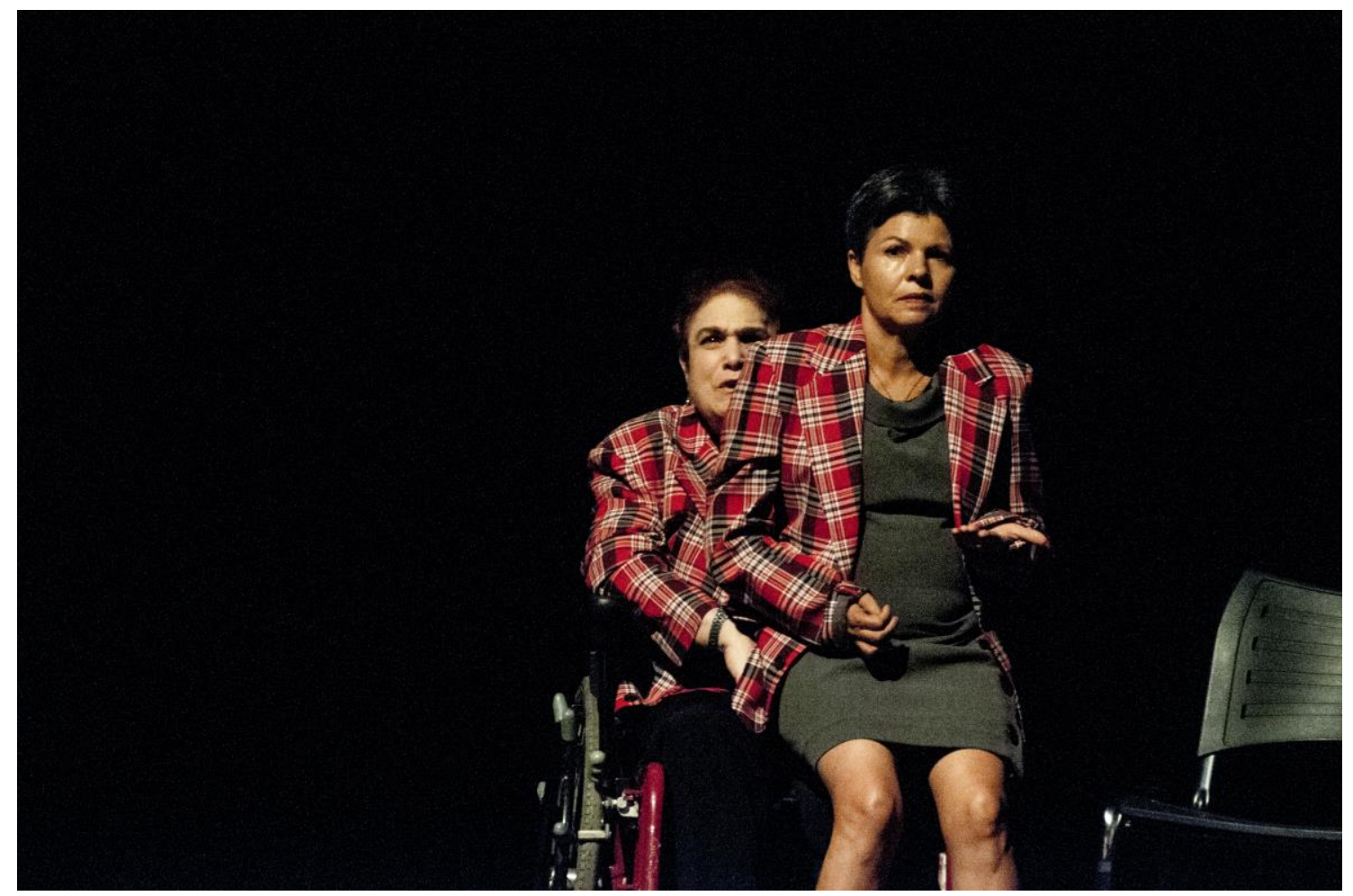

Orna Winter e Carmelita Silva (que substituiu Yasuko em 2019). Foto: Luís Dávila/Vila Imagem.

Novamente, tínhamos uma cena que não terminava. Para inventar um final, sugeri que o boneco se rebelasse, cansado das manipulações de sua dona, o que criava um contraste interessante, já que Yasuko é pequena e suave. Definimos o final da cena com a explosão delicada do boneco-Yasuko,

25 Quando entrei na ONG, havia alguns acompanhantes que já participavam dos encontros como uma espécie de suporte, sem participar das cenas e sem uma função definida. Naquele momento, propus que quem quisesse poderia ficar e seria do elenco como os outros, com a exceção de determinados momentos em que fosse preciso, por exemplo, dar remédios ou atender alguma questão específica. 
que em determinado momento salta do colo de sua manipuladora, tem um ataque, fala que não aguenta mais, sai correndo e deixa Orna sozinha no palco. Neste momento final, Orna fala "eu te amo", "obrigado" ou outra coisa, todas são igualmente potentes na estrutura da cena, que ganhou o nome de $O$ duplo e um figurino idêntico nas duas atrizes.

Os dois processos descritos por último se transformaram nas cenas Palavras e $O$ duplo, do espetáculo Silêncios, moléculas, dinossauros, formado por 25 cenas nas quais os integrantes do elenco seguram letras luminosas e anunciam o título de cada uma. Palavras era a quarta cena, e $O$ duplo a 19a; as duas cenas de alguma maneira se relacionavam graças a uma lógica e um fluxo próprios da atriz. A primeira cena ganhava uma dimensão mais densa. $\mathrm{Na}$ segunda, o estranhamento se acentuava pela presença da outra atriz no seu colo.

Depois do ataque e revolta do boneco, é interessante perceber que, pela estrutura da cena e pelo timing da atriz, que aguardava a saída do boneco para esperar e dar sua deixa, seja ela qual fosse, o ato sempre ganhava um aspecto cômico. Entretanto, é uma comicidade distorcida, um pouco estranha, pois feita de uma senhora sentada no colo de outra senhora que fala palavras em lógicas diferentes. O real transborda do emolduramento da ficção.

Quando Orna fala, usa as palavras que tem à disposição e que sempre querem dizer outra coisa, mas, ao mesmo tempo, diz as palavras que diz. Quando a atriz utiliza a fala desse modo, percebemos como as nossas palavras são também um emaranhado de clichês, de fórmulas que repetimos enquanto a comunicação acontece em outro nível, que envolve corpo, intenções, afetos e uma série de outros atravessamentos.

Ao ver e ouvir ela falar, a sensação em meu corpo é de alivio, de surpresa com o modo com que ela junta palavras desgastadas, ou clichês, embaralhando-as de um jeito que faz seu discurso ganhar um desconcerto que atravessa quem assiste. Vou, aqui, arriscar uma hipótese: esse desconcerto nos mostra como as palavras muitas vezes querem dizer outra coisa e libera, com esses outros usos, uma potência pré-linguagem. Essa potência tem algo de ingovernável e está relacionada às nossas próprias afasias e à intensidade que existe entre o que não é permitido ou possível de ser dito. A fala de Orna mostra como esses não ditos se transformam em outra coisa, em uma potência 
do que é, e não do que foi ou deveria ser. Em seu livro O inconsciente estético, Jacques Rancière escreve sobre como a

[...] interpretação freudiana se inscrevia no grande paradigma indiciário que procura reconstituir um processo a partir dos seus rastros ou sinais. Mas há também outro modelo, que vê no detalhe [...] não mais o rastro que permite reconstituir um processo, mas a marca direta de uma verdade inarticulável, que se imprime na superfície da obra e desarma toda lógica de história bem-composta, de composição racional dos elementos ${ }^{26}$.

As cenas de Orna devem ser vistas a partir desse outro modelo de que fala Rancière. Em seu modo único de usar as palavras, em vez de buscar as causas dessa singularidade em uma interpretação causal, tratando-as como vestígios, vamos perceber (sentir, que é diferente de interpretar) qual outra realidade se instaura com a sua maneira singular de falar. Ao entrarmos em contato com essa poética própria sem um anteparo interpretativo, nos afetamos por essa outra lógica ao invés de submetê-la à nossa. Mas para que isso possa acontecer, para se instaurar essa outra realidade, é preciso que ela seja legitimada, é necessário propiciar condições e um espaço de existência. Aqui, novamente, Lapoujade ilumina caminhos:

Tudo se resume a isso: tornar-se real. E tornar-se real é tornarse legítimo, é ver sua existência corroborada, consolidada, sustentada no próprio ser. Sabemos que a melhor maneira de solapar uma existência é fazer de conta que ela não tem nenhuma realidade. Nem mesmo se dar ao trabalho de negar, apenas ignorar. Nesse sentido, fazer existir é sempre fazer existir contra uma ignorância ou um desprezo. Temos sempre que defender o sutil contra o grosseiro, os planos de fundo contra o ruído do primeiro plano, o raro contra o banal $[\ldots]^{27}$.

Essa citação, que se refere a diferentes espessuras de existência - por exemplo, a chegada da primavera - também poderia se referir a relação de visibilidade e invisibilidade de quem pode estar em cena, ou de quem pode existir como pessoa em variados planos, sejam eles sociais, criativos, emocionais.

Orna vive em uma instituição de acolhimento que dá condições dignas de moradia, saúde, alimentação, mas imagino o quanto de mobilidade física,

\footnotetext{
${ }^{26}$ RANCIÈRE, Jacques. O inconsciente estético. São Paulo: Editora, 34, 2009. p.58.

${ }^{27}$ LAPOUJADE, 2017, p.91.
} 
social e existencial ela tem. A participação dela (assim como de outras pessoas da ONG Ser em Cena em que a linguagem ficou bastante alterada) possibilita que ela possa fazer circular os desejos, pertencimento, desenvolver a criatividade com a potência de seu modo desviante, com suas falas embaralhadas. Ela tem em nossos encontros um espaço privilegiado em que não há submissão à lógica da fala ordenada, como acontece em outras instâncias da sua vida.

Ao vermos esses corpos que não costumam ser vistos em cena, com seus funcionamentos e desfuncionamentos, somos convocados de uma maneira que gera abertura de poder ver e sentir o outro em uma variedade existencial que transborda esquadrinhamentos ou horizontes de expectativa, estéticos ou patológicos.

Como vimos nos casos de Ana, Léo, Orna e Sophie, essa abertura não acontece naturalmente. Para se colocar outros corpos em cena e para que possamos descobrir formas de tornar possível a criação de uma poética própria por meio dessas heterogeneidades, há uma série de negociações, tentativas, fracassos, mudanças de rota e experimentações. Dos impasses que surgem no caminho, alguns não surgem no momento da criação, mas nas apresentações ao público, no compartilhamento desses outros jeitos.

\section{Clap - sobre impasse dos aplausos}

Por um lado, temos a potência poética e existencial de uma cena que propõe outra circulação de valores. Por outro lado, temos um excesso de aplausos durante algumas cenas. Fiquei me perguntando por que os aplausos incomodaram tanto? David Lapoujade nos dá uma pista quando escreve como é preciso imaginar operações, estratégias para que a legitimação desses diferentes modos de existência possa acontecer.

Trata-se de fazer ver, de tornar perceptíveis novas classes de seres, até os que são invisíveis. Temos, então, um primeiro momento que consiste em empurrar para fora do plano todos os pressupostos, os preconceitos, as ilusões que bloqueiam essa renovação da percepção. A redução é, primeiramente, uma operação de limpeza. É preciso purificar o campo de experiência de tudo aquilo que impede de $v^{2}{ }^{28}$.

\footnotetext{
${ }^{28}$ LAPOUJADE, 2017. p.48.
} 
Na cena de Léo e Evelyn citada no início deste capítulo, assim como em outros momentos dos espetáculos da Ser em Cena, as pessoas aplaudem no meio ou no final de uma cena. São sempre impressões subjetivas, é difícil explicar com precisão o que são esses aplausos no meio de uma apresentação, mas existem tipos diferentes de aplausos, e é possível intuir algumas diferenças.

Temos, por um lado, o transbordamento de uma emoção que não consegue ser contida, um curto-circuito que desnorteia e promove uma abertura $^{29}$. Mas temos também um tipo de aplauso que impede o surgimento de um outro olhar, que não deixa que aconteça essa renovação da percepção de que fala Lapoujade. Pode soar um pouco arbitrário falar em uma pesquisa em um incômodo causado por um aplauso, mas os parâmetros são subjetivos e esse incômodo de algum modo é um termômetro.

Esses aplausos incomodam porque me parecem condescendentes, e restringem os diferentes modos de existência que vemos em cena a um determinado aspecto (de uma suposta superação pessoal), não permitindo o surgimento de outros aspectos, por exemplo a linguagem que se instaura ali, a beleza da cena. Uma parte do público é de familiares e amigos dos atores e atrizes, e parece que há um ranço, um fantasma de escola de balé que assombra a apresentação, gerando um aplauso, às vezes, ao final de uma cena que não era especialmente emocionante, mas que tinha um silêncio. Ou então quando surgem figuras diferentes em cena.

É difícil lidar com a impotência de ver o público aplaudindo nesses momentos, sem perceber que seu parente ou amigo está construindo cenas, arriscando uma linguagem, inventando outro tipo de beleza a partir de sua existência, e é preciso silêncio para deixar que alguma coisa reverbere. Dar uma forcinha na verdade tira a força do que está sendo feito, dar uma força impede de perceber as "fraquezas", as sutilezas e vulnerabilidades;

\footnotetext{
${ }^{29} \mathrm{Em} O$ outro lado do oceano, na cena das criaturas marinhas (que descreveremos mais adiante), cada vez que ensaiávamos, as pessoas presentes se emocionavam, de modo que não era surpreendente quando as pessoas aplaudiam no espetáculo. Assim como na cena em que Reinaldo, um senhor que está no grupo há catorze anos, canta a música My Way, do Frank Sinatra. Além da carga emotiva dessa canção, o ator comentou que cantar essa música em cena era uma das cinco coisas que ele queria fazer antes de morrer. Também não foi surpreendente a manifestação do público ali, pois o ator fez a cena de um modo que convoca ao aplauso por sua carga emotiva.
} 
impossibilita notar que a cena é feita de partes que se entrelaçam, que há um encadeamento entre as partes que constrói um ritmo coletivo, e que a cena é também feita desse ritmo.

Querido público: aplaudir a cada cena é congelar os atores e atrizes em uma posição de "exemplo de superação", como se não fosse possível ser outra coisa, sair desse papel da pessoa que se superou. Sim, ela se supera a cada dia, assim como cada um de nós nos superamos a cada dia, cada um com suas dificuldades e necessidades, mas ela está criando linguagem e vocês não estão vendo.

Não tenho respostas para isso, pois, por outro lado, são pessoas que tiveram acidentes que mudaram suas vidas - indivíduos com afasia têm um antes e um depois bem definidos, trata-se de recompor a vida depois de um desastre - e, por meio do teatro, estabeleceram novamente conexões, um pertencimento e um sentido coletivos. As famílias que vêm assistir vibram e se emocionam com isso de alguma forma e isso também é legítimo. No entanto, convive com essa vibração uma outra, que achata a experiência e quase anula a potencialidade, a riqueza e a força da experiência com esse barulho.

As vulnerabilidades, as fragilidades com que trabalhamos, geram outros modos de se estar em cena, e pedem também outros modos de fruição. É necessário silêncio, tempo, escuta para algo novo acontecer, para alguma coisa de outra ordem se instaurar. Acho que é preciso conviver com a contradição, levar em conta a convivência desses contrários. Ao mesmo tempo que o aplauso é um mapa que tenta impedir as desterritorializações, sempre pode haver um algo que escape a categorias patologizantes, e por isso mesmo cause esse transbordamento.

\section{Reinvenções: produzindo outros Outros}

Ao pensar na necessidade de silêncio para se observar algumas cenas, voltamos à Whitehead. Quando ele reivindica que a estética saia desse lugar de contemplação passiva, é preciso incluir que a passividade também pode ser feita de barulho e de gestos, como os aplausos. Assim como o propósito de tirar a estética de uma posição anestesiada pode se dar pelo silêncio, pela escuta e pela observação. 
Tirá-la dessa posição é lembrar que a estética é também uma ética. Esses corpos geralmente não participam do campo da arte, fogem de um senso comum do que seria normal ou aceitável fazer em uma criação cênica; subvertem a expectativa de que corpos normalmente vemos em cena ou encontramos em instituições de cuidados ou saúde mental.

Ao embaralhar categorias, sejam elas estéticas ou clínicas, podemos "abrir o pensamento ao desatino ao invés de enclausurar a loucura com certo conceito de razão", como nos fala Peter Pál Pelbart ${ }^{30}$. Nossos atores e atrizes muitas vezes são pessoas que sofrem, mas além de sofrer sentem prazer, criam, cuidam do gato, fazem restauração de livros ou se formaram em geografia. Classificá-las em primeiro plano como doentes, sofredoras ou afásicas é um mecanismo de controle clínico e social. Vê-las de um modo que leve em conta outros aspectos, em outro diapasão, nos ajuda a "abrir nosso pensamento ao desatino" ${ }^{31}$ e aos mais diferentes modos de vida.

Esse gesto tem implicações que proporcionam saber habitar uma fronteira e criar linguagem nessa fronteira - de linguagem, de ritmos, de tempo -, em vez de enclausurar esses coletivos em nichos clínicos patologizantes, como doentes mentais ou afásicos; ou políticos e estigmatizantes, como "pessoas especiais"; ou ainda com o uso da expressão "inclusão".

A "inclusão" pressupõe que alguém está do lado de dentro inclui alguém que está do lado de fora. Isso acaba reforçando algo que se queria abolir, além de excluir o outro em sua complexidade. Uma sociedade verdadeiramente inclusiva não precisaria da palavra inclusão. Respeito quando essa palavra é usada, pois a estrutura hierárquica dos incluídos e excluídos pode ser importante para a sociedade quando se pensam propostas de políticas públicas. Entretanto, se a arte é a invenção de novos sentidos, então, em nossos processos criativos, podemos subverter isso e imaginar nossa própria utopia, todo mundo está dentro. Sinto-me desconfortável com esse termo, que me parece uma espécie de paternalismo ou condescendência com os "incluídos". A performer Estela Lapponi postula em seu manifesto anti-inclusão

\footnotetext{
${ }^{30}$ PELBART, Da clausura do fora ao fora da clausura. São Paulo: Brasiliense, 1989. p.19.

${ }^{31}$ Ibidem, p.19.
} 
que a "Inclusão propõe hierarquia de capacidades", "não interage", "exclui" e "isola"32.

Em vez de restringir as pessoas diferentes a nichos, como "inclusão", criar junto ou observar uma cena feita de belezas discordantes, pode abrir espaços para que os desviantes, os mais diversos, com seu modo peculiar, reinventem nossas ficções e narrativas sobre o papel que ocupam.

Desse modo, determinados comportamentos que em outros contextos seriam considerados patológicos, irrelevantes, ruidosos, em nossos coletivos ganham legitimidade e gramáticas próprias. Assim como a poesia de certa forma reinventa a gramática existente na criação de novos sentidos, em nossos processos procuramos inventar uma poética própria, buscando uma linguagem que dê conta de nossas singularidades.

Essa procura não é da ordem do grandioso ou oficial, mas acontece cotidianamente em nossos encontros. Lida com manifestações do extraordinário contidas dentro do banal, com códigos oficiais, caminhos supostos; e trabalha com o modo como as histórias extraoficiais irrompem dentro do que é suposto, legitimando-as graças ao risco e ao inesperado, e permitindo o surgimento de possibilidades diferentes das imaginadas ou traçadas. ("Existem mapas que decodificam o mundo, mas, quando há um rasgo no mapa, entra o mundo $33 . "$ )

Experimentamos como o risco transforma toda a gramática afetiva de um território, seja ele existencial, micropolítico ou estético. Como refugiados que somos de uma terra que não dá conta de nossos desencaixes, precisamos inventar outros jeitos, gestos menores, vias vicinais que se tornam os caminhos percorridos de fato.

Descrevi anteriormente que a primeira vez que vejo as pessoas que vêm de instituições de saúde mental, que lidam com autismo ou com pessoas com afasia, prefiro não saber inicialmente qual é o diagnóstico ou as limitações oficiais deste ou daquela. Procedo assim pois é a partir de nossos encontros

\footnotetext{
${ }^{32}$ LAPPONI, Estela. Manifesto anti-inclusão. Disponível em:

$<$ http://estelapponi.blogspot.com/2012/05/anti-inclusao-manifesto.html>. Acesso em: 7 jun. 2019.

${ }^{33}$ Conversa realizada com o psicanalista e dramaturgo Sergio Zlotnic acerca de processos criativos e suas semelhanças com o processo psicanalítico de decodificação dos mundos singulares de cada um.
} 
que as descobertas acontecerão: seus recursos internos, seus modos criativos de expressar, sua coragem em experimentar outras possibilidades de estar em cena e criar. A complexidade e a plasticidade do cérebro e dos recursos de uma pessoa são surpreendentes.

Por que um determinado aspecto biográfico de um indivíduo precisa ter protagonismo sobre outros? Quando falamos de propor outra circulação de valores, o discurso patológico-farmacêutico deixa de ter supremacia, e outros modos de conexões podem surgir quando vemos as pessoas como um conjunto maior. Cada um pode escolher o que contar: se toma remédios, se tem medo de água, se não suporta coentro, anota os sonhos ou gosta de cumbias, de que cidade veio.

Em 2004, com a Cia. Zaum, ao elaborar o programa da peça Comendador Peçanha, apresentada na biblioteca Mário de Andrade no ano seguinte, decidimos fazer uma minibiografia poética de cada um dos integrantes do espetáculo (que contava com atores, atrizes, performers e músicos convidados, em um total de 29 pessoas). Com essa minibiografia poética pudemos rever certas noções de currículo, competência ou status, ao perguntar para cada pessoa o que achava relevante e queria colocar em sua descrição. Seguem alguns trechos desses pequenos currículos poéticos do programa:

Marcos (o) Sanchiú é ator desde os 4 anos de idade, quando criou, com Emília, as peças FBI, Rei do faroeste, Superamigos, Papai e Mamãe, Detetive Particular e O caçador. Entusiasta de Jeová, Deus, Buda e Krishna. Leitor de Klauss Bliesener e Bruce Tegner. Interpretou por causa da Marcinha, aquela malandrinha, o super-homem, o espião da KGB e até as Panteras.

lone S. Costa quando mais jovem era do tipo oito ou oitenta, hoje já aprendeu a engolir sapos e a esperar o momento certo para responder coisas que the desagradam. Quando criança teve muitos bichos, cachorros, gatos, pássaros e até um pombo que pegou o bebezinho, o Sam. Aprendeu que "rir é bom, mas rir de tudo é desespero". Era do tipo rebelde e quando trabalhava estava sempre no meio das greves.

Anselmo Reis Barreto concluiu o ensino fundamental e trabalhou como auxiliar de serviços gerais. Gosta de passear no centro de São Paulo, no viaduto do Chá e no viaduto Santa Ifigênia, onde tem vendedores, jardim e igreja. Também gosta de passear em São João Clímaco. De vez em quando fica na praça se divertindo. 
Erik Johnsons, quando estava na primeira série, o professor de educação física veio buscar lhe na sala de aula para que pudesse transmitir para os rapazes da sétima e oitava série todos os ensinamentos que ele havia obtido. Quando adolescente, num salto mortal, perdeu dois dedos do pé direito e quebrou o braço. Mais tarde se envolveu com drogas, furto e assalto, mas conseguiu salvar a vida de uma pessoa na piscina.

Peri Pane é compositor e performer. É artista PET, e sobretudo mimeógrafo. Gosta de guardar coisas sem valor que acha na rua. Há nove meses, trocou o vício da nicotina por aulas de violoncelo. Já faz escalas razoáveis de dó, sol e fá maior.

lonir Mans. Teve sua formação como professora de história, mas acabou mesmo como desenhista de $\mathrm{HQ}$. O que mais gosta é cinema. É fã de Charles Chaplin, Hitchcock e Brian de Palma.

Fotografia 21 - Comendador Peçanha - Cia Zaum, 2005

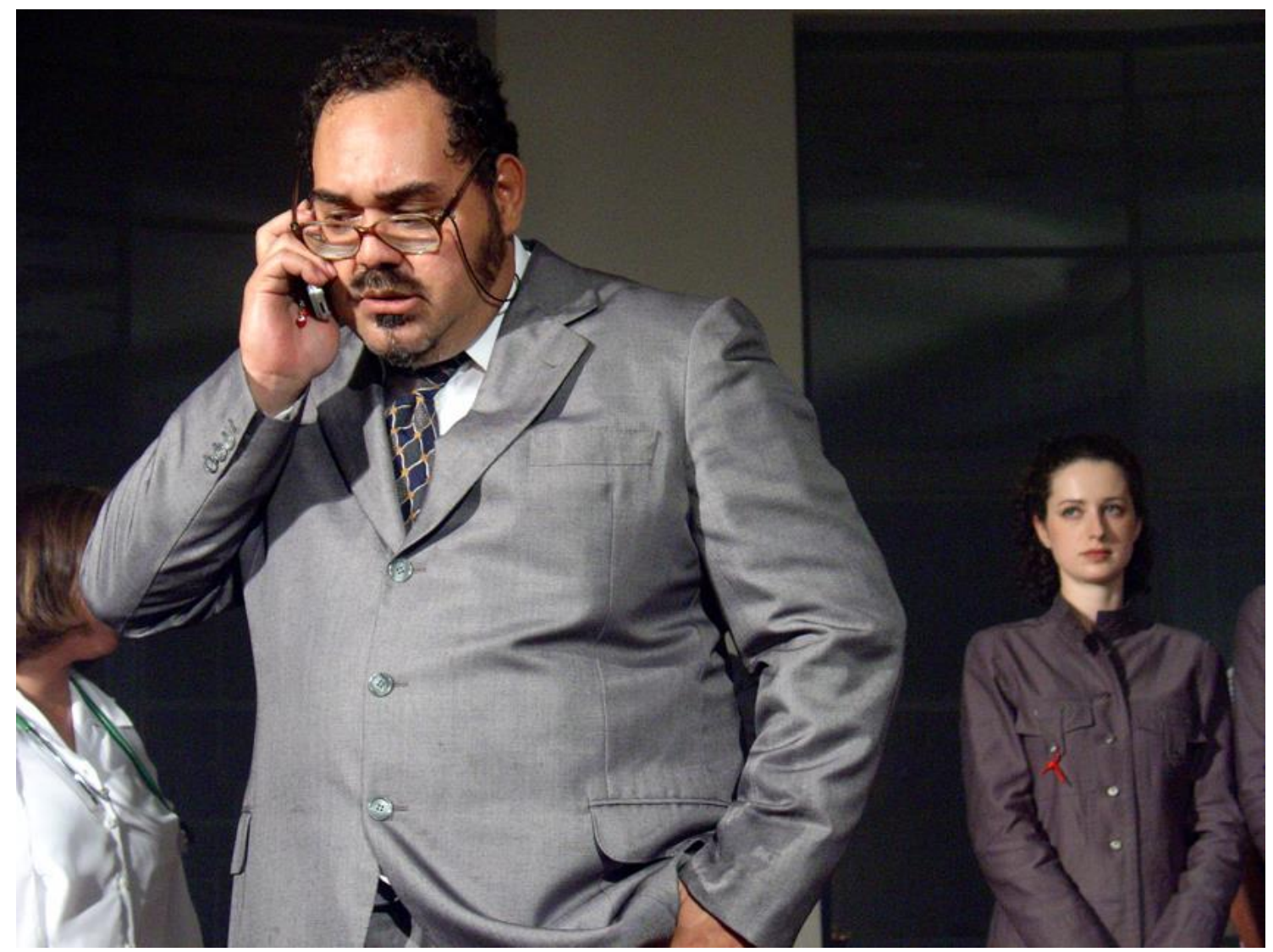

Chrystian Costa, Marcos (Ô) Sanchiú e Elisa Band. Foto: Acervo pessoal.

Podemos ver nesses exemplos de descolamento do que é oficial (seja do discurso biográfico/curricular, seja psiquiátrico) tentativas de se experimentar outros tipos de valoração. Arriscar diferentes lugares de 
legitimação questiona os existentes e ao mesmo tempo ilumina e valoriza outras áreas, habilidades ou inabilidades igualmente importantes; ou melhor, questiona a própria ideia de importância ou de relevância.

Um dado que é relevante para uns, por exemplo saber o número da patologia classificada pelo $\mathrm{DSM}^{34}$ de certa pessoa, pode ser irrelevante para outra pessoa, que irá preferir que saibam que ela salvou a vida de alguém na piscina ou começou a gostar de teatro por causa da Marcinha, aquela malandrinha.

Do ponto de vista da criação artística, o descolamento dos discursos médicos nos traz a possibilidade de nos conectar a uma certa vitalidade das pessoas e dos processos.

Como nosso aliado na ideia de um tanto de autonomia em relação aos diagnósticos oficiais, podemos invocar Fernand Deligny, um psiquiatra francês que desenvolveu um importante trabalho com autistas durante anos. Em seu trabalho, ele não tinha prontuário e não queria saber a história pregressa ou as terminologias médicas, porque sabia que nesse discurso vinham embutidos na linguagem os preconceitos, a exclusão, a invisibilização. Ele partia daquilo que era a vivência dele com aquelas pessoas, sem domesticar as experiências em qualquer discurso simbólico, clínico ou psiquiátrico ${ }^{35}$.

Para concluir, retomo a figura de Léo e sua cena contrastante, as camadas de sentido e forma da performance de Ana, os modos desviantes de Sophie e a reinvenção de língua-mundo de Orna. Com suas gramáticas próprias, seus modos de falar, pensar e sentir podem nos ajudar a pensar como o aspecto intrigante (awe) e as camadas divergentes desses trabalhos nos dão pistas de como ver as pessoas para além das patologias.

Essa abordagem precisa ser acompanhada de um questionamento do enquadramento desses trabalhos dentro de gêneros ou linguagens artísticas pré-definidas. Essas instâncias têm que acontecer juntas, pois uma legitima e potencializa a outra (sair dos nichos especiais e a doença não vir antes da pessoa) para que a gente possa experimentar outras formas de circulação.

\footnotetext{
${ }^{34}$ AMERICAN PSYCHIATRIC ASSOCIATION et al. Manual diagnóstico e estatístico de transtornos mentais: texto revisado (DSM-IV-TR). [S.I.]: Artmed, 2002. Manual utilizado para diagnóstico psiquiátrico.

${ }^{35}$ DELIGNY, Fernand. O aracniano e outros textos. São Paulo: N-1 Edições, 2015.
} 
Em nossos encontros e experimentações, na beleza discordante de nossas criações, não se trata apenas de abordar outras formas, mas de produzir outros sujeitos, que não o louco ou o afásico como o conhecemos, ou o artista como o imaginamos, nem uma mistura dos dois, mas um ser múltiplo feito dessas instâncias, e também de outras, que ao ser legitimado em sua multiplicidade vai suscitar uma reinvenção das categorias disponíveis para classifica-lo.

A nossa intenção é imaginar uma outra percepção de arte, de beleza, de relações, para um desentendimento e um desencaixe do mundo e no mundo que geram outros tipos de participação. É preciso vislumbrar outros lugares para o não condizente, para as divergências, em que os pontos fora da curva deixem de sê-lo não porque passem para o lado de dentro, mas porque pontos e curva fazem parte de uma mesma paisagem.

Nossos corpos têm particularidades, necessidades, jeitos de se mover, de se expressar, hesitações, balbucios, de tremer, de perder o equilíbrio ou atingir três oitavas. E o que fazemos com isso? Como podemos pensar nessas existências de modo que se escape de lógicas que excluem, silenciam e tornam invisíveis os corpos ou os supervalorizam? Como desmanchar essas lógicas que se repetem nas artes, na clínica, no cotidiano? Como abrir brechas em certos esquemas estéticos e existenciais para que surjam outros?

Cada vez mais tenho pensado que as experiências com esses coletivos podem apontar possibilidades que nos fazem repensar diariamente sobre arte, vida, limites, desejos, tamanhos. Ao repensar a beleza e sua potência, também é preciso repensar mercados, lugares de exibição, legitimação e visibilidade. Pensando que o outro nunca é dado, mas produzido ${ }^{36}$, é uma coreografia delicada que estamos experimentando: essa tentativa de se produzir outros sujeitos que não estejam submetidos a lógicas formatadoras, seja da linguagem ou da patologia, mas que possamos imaginar outros Outros.

\footnotetext{
${ }^{36}$ Fala de Peter Pál Pelbart em palestra do Projeto Museu Encantador, Centro Cultural Banco do Brasil, São Paulo, 20 fev.2016.
} 
Fotografia 22 - Curso de performance do Igual Diferente - MAM, 2018

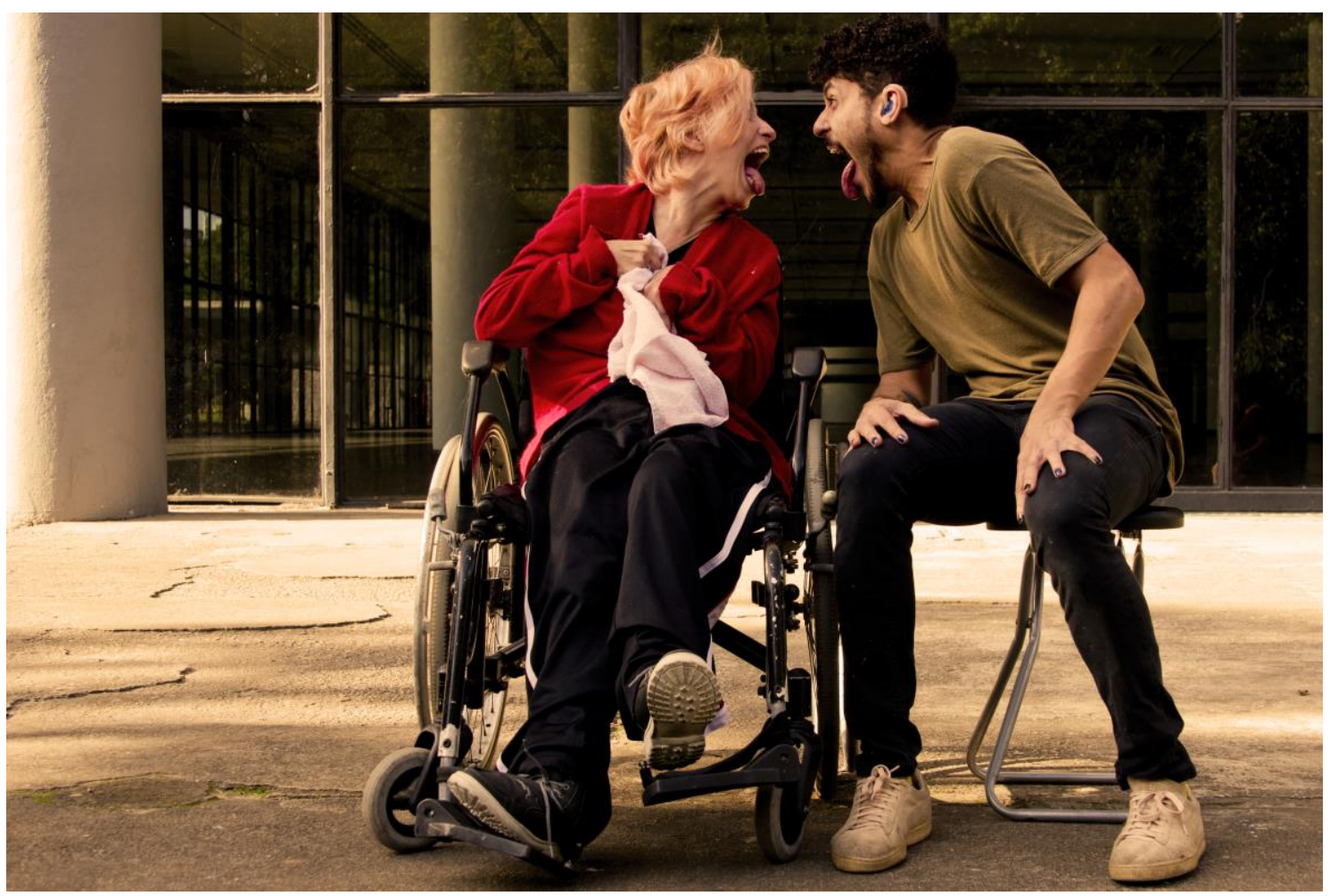

Alessandra Grimaldi e Leonardo Castilho. Foto: Karina Bacci.

DESASTRES, ALFÂNDEGA E DERIVA

Devemos então supor que se introduzirmos um intervalo de tempo entre a ação e a reação, entre a causa e o efeito, entre o imperativo e a nossa resposta, se introduzirmos a duração de uma hesitação, estaremos introduzindo no mundo uma certa porção de liberdade? Essa diferença de ritmo não é a própria liberdade ${ }^{37}$ ?

\section{Pequenos desastres}

Em 2016, no primeiro encontro com uma das turmas da Ong Ser em Cena pedi para as pessoas contarem uma história relacionada ao tema "viagem". Poderia ser um relato vivido, inventado, a partir de um filme, de um sonho ou de ouvir alguém falar. Chegou a vez da Paula. O vocabulário dela é reduzido ao essencial. Há um pequeno intervalo de tempo entre uma palavra e

\footnotetext{
${ }^{37}$ LAPOUJADE, Potências do tempo. São Paulo: N-1 Edições, 2017. p.24.
} 
outra; nesse esforço em encontrar a palavra, é como se nós tateássemos junto com a sua boca procurando a posição certa do próximo som. O que ela contou: "Ano novo. Ilhabela. Nós. Barco. Perdidos. Água? Não. Comida? Não. 4 horas. Lancha veio". Fui sugada pela história e pelo modo singular com que foi narrada. Vi como uma particularidade pode ganhar espessura de linguagem. A fala me chamou a atenção não somente pela velocidade com que acontecia, mas também pelo modo com que Paula fazia isso.

Ela não tinha pressa, apesar de algumas vezes ficar frustrada com alguma palavra que não vinha, e falava (ainda fala) de um modo que eu poderia chamar de desenvolto, ou à vontade. Apesar de parecer um paradoxo usar essas palavras para descrever alguém procurando as sílabas de palavras básicas, como substantivos e artigos, é assim que me parecia que ela lidava com seu modo de se expressar.

Nos encontros seguintes, fui aprendendo a saber escutar dentro desse outro tempo mais distendido, diminuindo a minha ansiedade e também pedindo para as outras pessoas (colegas do elenco e equipe) que evitassem tentar "ajudar" com palavras, o que transformava a conversa em um jogo de adivinhação: ela perdia a chance de desenvolver os seus recursos e nós, a capacidade de escuta.

Pudemos ver a beleza dessas histórias que se aproximam aos poucos, instauram outro tempo e exigem entrega de quem escuta. Também conversei em particular com ela. Expliquei que via uma possibilidade cênica no jeito dela contar as histórias: o modo com que ela atualmente se expressava era poético, poderia compor uma cena, e queria saber se ela estava à vontade com isso. Essas conversas são importantes para dimensionar se o que estou sentindo que é também movido pela estética, sem descuidar de um olhar sensível - se afina com o que a atriz sente. Esse mesmo tipo de conversa aconteceu em outras situações (como o caso da Orna descrito anteriormente). Paula se animou com a experiência. Cada uma de nós se deslocou para que algo acontecesse.

Por mais que analisemos os motivos pelos quais a cena tem potência, que podem ser o modo desenvolto dela, sua expressão, seu timbre, seu ritmo etc., alguma coisa escapa, que é própria pessoa e a sua singularidade, a sua 
faísca criativa, que poderíamos chamar de centelha, ou, como o encenador Jerzi Grotowski falava, élan:

O élan de uma ação pode ser entendido como seu sopro de vida, ou seu impulso vital, algo de enigmático, de conhecido, porém não sabido, que nos impulsiona à ação, à vida, por meio das ações. Por esses motivos, o élan de uma ação é um de seus componentes mais importantes, pois remete a uma possível complexidade pluridimensional de uma ação física ${ }^{38}$.

O modo de Paula narrar tem uma capacidade de imantação que tem a ver com uma série de fatores, mas fica uma parte que não se explica. Na parte que nos é possível analisar, percebemos que sua fala amplia nossa perspectiva ao desfamiliarizar o que temos de familiar, como o ato de contar uma história. Ela ressignifica o ato de falar durante suas narrativas e suspende temporariamente os atributos de tempo e fluência normalmente dados às palavras, abrindo espaços originais de afeto e entendimento também em quem vê.

Fotografia 23 - Cena: Desastre número um. Silêncios, moléculas, dinossauros - Ser em Cena, 2018

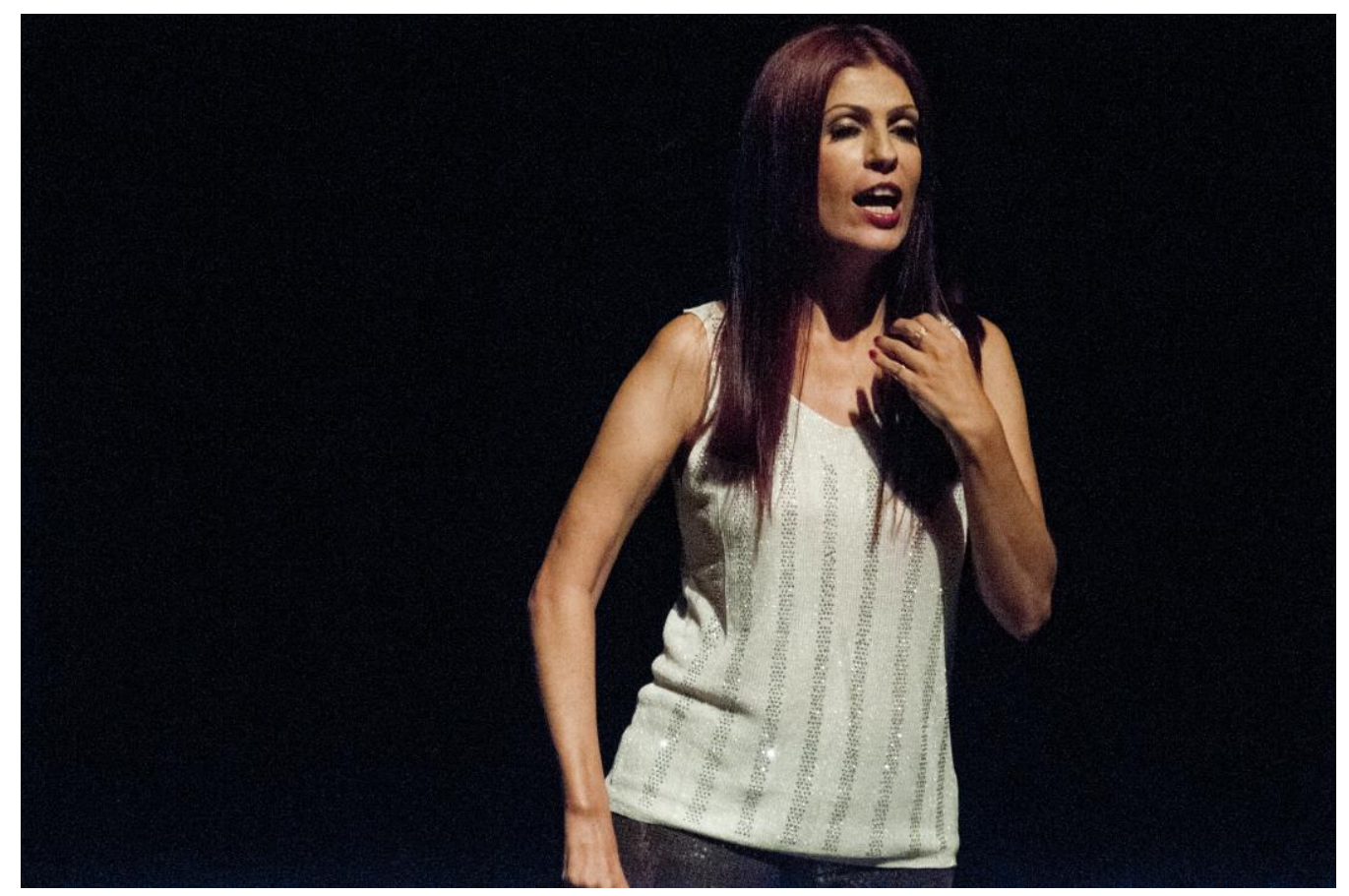

Paula Maia. Foto: Luís Dávila/Vila Imagem.

\footnotetext{
${ }^{38}$ BURNIER, 2009 apud SILVA, Lidia Olinto do Valle. Conjunctio oppositorum e o parateatro de Jerzy Grotowski e companhia (1970-1982). Campinas, 2016. Tese (Doutorado em Teatro, Dança e Performance) - Instituto de Artes, Universidade Estadual de Campinas. p.18
} 
A sua singularidade não significa que a cena "nasça pronta": o modo dela se expressar é o nosso horizonte de expectativa, mas dentro desse horizonte existem aprimoramentos dramatúrgicos. Clínica e estética se atravessam: o trabalho dramatúrgico posterior às suas improvisações aumenta o seu vocabulário, assim como o seu aumento de vocabulário influencia na elaboração da dramaturgia.

Em 2018, ela trouxe outra história (a partir do tema infância): "Eu tinha oito anos. Missa com meus pais. Carro. Banco traseiro. Bolsa. Batom vermelho. Espelho? Não". Ao final ela fazia um gesto com a mão de quem estava passando batom, o carro deu solavanco, a mão escapou da boca e borrou o rosto. Lembrei da narrativa do barco, de algum modo ambas se relacionavam. A partir dessas duas histórias e do tema do espetáculo que estávamos criando - que se relacionava com listas, itens e verbetes -, pedi que ela trouxesse mais uma história para experimentarmos um trio a partir dessas narrativas que abordam um pequeno acidente: histórias em que algo sai do plano e perde o controle.

Ela trouxe então esse relato: "Quando eu era adolescente, férias fazenda avô. Fui andar cavalo. Cobra. Cavalo galopando. Controle? Não. Rédea? Não. Gritando? Sim. Meu pai veio ajudou". A partir disso, propus acrescentarmos finais inusitados e/ou poéticos, e inserimos essas narrativas durante o espetáculo.

As narrativas ficaram assim:

Desastre n. 1

Eu tinha 8 anos. Missa com meus pais. Carro. Banco traseiro. Bolsa, espelho. Batom vermelho. Espelho, não. (Gesto) Eu queria ficar bonita pra deus.

Desastre n. 2

Férias. Paraty. Barco. Alto-mar. Barco quebrou. Comida? Não. Água? Não. Telefone? Não. Cinco horas. Perrengue. Resgate. Noite ${ }^{39}$.

Desastre n. 3

Quando eu era adolescente, férias fazenda avô. Fui andar cavalo. Cobra. Cavalo galopando. Controle? Não. Rédea? Não. Gritando? Sim. Depois de três dias, placa: Bien-venido ao

\footnotetext{
${ }^{39}$ A palavra llhabela estava difícil de ser falada; Paula ficava constrangida porque praticamente nunca a palavra era falada, e o que saía era uma mistura de vogais que desmanchava demais a narrativa logo no início, então experimentamos Paraty que ficou fácil. Já a dificuldade dela de falar a palavra perrengue funcionava, porque apesar de ser uma palavra mais difícil que as outras e gerar muita concentração nela e no público, ao final sua dificuldade e o inusitado da palavra causavam um efeito cômico.
} 
México. (Saem mariachis do fundo da coxia e dançam uma música mexicana no tempo de Paula sair da cena.)

Durante o espetáculo, Paula contava para o público essas pequenas histórias, anunciadas (como as outras cenas do espetáculo) pelos títulos: Desastre número um, Desastre número dois, Desastre número três. As cenas poderiam ser chamadas de números de cortina, cenas que acontecem mais para a frente para que sejam montadas ou desmontadas outras cenas coletivas mais ao fundo do palco (o que geralmente leva um certo tempo devido às dificuldades de locomoção de parte do elenco). Não considero essas como cenas de passagem. No entanto, ao mesmo tempo, na criação da dramaturgia do espetáculo, é preciso levar em conta o tempo distendido não só da cena, mas da sua montagem e desmontagem. A simultaneidade dos relatos e da montagem/desmontagem funcionou ao criar um encadeamento mais dinâmico das cenas. Por outro lado, aqui foi um recurso que resvalou em uma dualidade redundante: tínhamos uma cena narrativa, mais iluminada e mais à frente; e cena de montagem mais ao fundo, com menos luz. Ao rever essa cena, percebo que consideramos as coisas mais "prontas" "dignas" de estar no foco, enquanto o disforme (a cena ainda sem forma) ficou menos evidenciado; precisaríamos pensar outro tipo de organização desses elementos na composição dessa cena, para que pudesse promover uma abertura de sentidos.

Analisando especificamente as narrativas de Paula, temos um exemplo de invenção de outros modos de usar a linguagem. Podemos também nos perguntar se a palavra mais adequada é usar. Por um lado, nós usamos a linguagem, mas, por outro, a linguagem nos usa, ou somos a linguagem. Pois a linguagem não apenas nos dá um parâmetro subjetivo para o entendimento do mundo, ela também cria outros. Esses outros mundos (e outras possibilidades de fruição), no nosso caso, foram acessados por uma desaceleração, que causa desfamiliarização. Essa desfamiliarização faz com que os mapas ordinários de codificação aqui sejam insuficientes. Quando vamos para um lugar sem mapas, não estamos mais abertos para inaugurar novas coordenadas? 
Para examinar esses outros mundos, que são acessados pela fala estendida e pelos silêncios, vamos nos deter um pouco mais na questão do tempo e na experimentação de durações estendidas de uma cena, seja das palavras, dos silêncios entre as palavras, seja dos movimentos.

Para isso, além da narrativa de Paula, vamos analisar também a cena da Alfândega ${ }^{40}$ e a cena da Deriva ${ }^{41}$, criadas junto aos coletivos da ONG Ser em Cena e da Cia. Ueinzz, respectivamente.

\section{Alfândega}

Em uma rodada de improvisações, dividimos a turma em duplas ou trios e pedimos que cada grupo criasse uma cena a partir do tema da alfândega.

Uma das duplas, Michel e Odilon, improvisaram a seguinte situação: Michel (alfandegário), sozinho na área cênica em frente a uma mesa, anunciava: "Próximo!". Odilon se apresentava e tirava objetos de dentro de uma mochila, um a um, os mais cotidianos e ordinários, como uma camisa xadrez e um desodorante, e esses objetos eram sempre proibidos de serem levados. A cada objeto mostrado, Michel gritava, por exemplo, "Camisa xadrez fica!".

Nessa improvisação, o que me pareceu interessante foi a possibilidade de subverter o que geralmente é associado a objetos que podem ou não ser levados em uma viagem. Além disso, o humor do alfandegário - que parecia sempre a ponto de ter um ataque de nervos - não combinava com os objetos inspecionados. Entre esses itens havia um pote de plástico contendo letras emborrachadas (usado para atividades de estimulação cognitiva). Quando o alfandegário tirou o pote da mochila houve o seguinte diálogo:

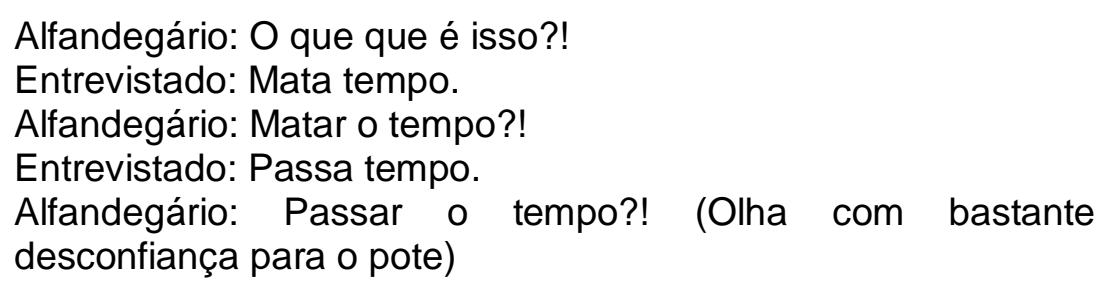

\footnotetext{
${ }^{40}$ Espetáculo Do Outro Lado do Oceano, (Ser em Cena) 2016 e 2017.

${ }^{41}$ Espetáculo Finnegans Ueinzz, (Cia. Ueinzz), 2009 a 2011.
} 
O entrevistado demorava para dar as respostas, e respondia com uma certa insegurança, pois parecia procurando a palavra (imagino que nas primeiras respostas ele estava tentando falar passatempo).

Desenvolvemos a dramaturgia a partir dessa improvisação. Havia pensado em tirar o desodorante, já que poderia ser realmente confiscado, se fosse um líquido com mais de trinta mililitros (de acordo com as regras aeroportuárias atuais), mas manter o produto fazia o absurdo acontecer de modo gradual.

Em lugar de considerar um "engano" falar mata tempo (ao invés de passatempo), observamos que essas expressões são ficções que dão a ilusão de controle e valoração do tempo: como ganhar tempo, perder tempo, matar tempo, passatempo. Essa variação de palavras poderia esgarçar seus significados e desmontar um pouco a arbitrariedade dessas expressões, de modo a sobrar, como elemento mais importante (no sentido de mais lembrado), a palavra tempo.

Também propus mais um momento para se experimentar essas diferentes temporalidades: em um determinado instante, os performers congelariam os movimentos por um tempo suficiente para que se instaurasse uma suspensão que conferisse estranheza ao andamento da cena.

Trocamos o objeto (pote com as letras emborrachadas), que não era reconhecível, por uma ampulheta. Além disso, incluí o diálogo das partes do corpo que tive com Ronaldo, descrito no Capítulo 2. A cena ficou assim:

\footnotetext{
Alfândega

(Alfandegário chega e dá uma bronca, manda arrumarem tudo e montarem o seu escritório. Assistentes colocam uma mesa. Um homem se aproxima com uma mala.)

Alfandegário: Próximo!

Entrevistado 1: Bom dia.

Alfandegário: Bom dia. Deixa eu ver a mala, faz favor.

(Entrevistado 1 abre e mostra um objeto.)

Alfandegário: O que que é isso?!

Entrevistado 1: Desodorante.

Alfandegário: Desodorante? Não! Desodorante não! Desodorante fica. (Entrevistado 1 tira outro objeto da mala). $\mathrm{O}$ que é isso?

Entrevistado 1: Camisa xadrez.

Alfandegário: Camisa xadrez?! Não! Camisa xadrez não pode. Camisa xadrez fica.

Entrevistado 1 mostra uma ampulheta.

Alfandegário: $E$ isso aqui é o que?

Entrevistado 1: Passa tempo.
} 


\author{
Alfandegário: Passa tempo? \\ Entrevistado 1: Perder tempo. \\ Alfandegário: Perder tempo?! \\ Entrevistado 1: Ganhar tempo. \\ Alfandegário: Ganhar tempo?! Ô amigo. Não, não, não! Aqui o \\ tempo é outra coisa. Ó. (Pausa, alfandegário aponta para \\ frente, entrevistado 1 acompanha com olhar $e$ os dois \\ congelam por uns vinte segundos). Viu? Tá liberado. \\ Entrevistado 1 sai. \\ Alfandegário: Próximo! Boa noite. \\ Entrevistado 2: Boa noite. \\ Alfandegário: (Olha para o entrevistado 2 estranhando). E a \\ mala? \\ Entrevistado 2: Não tem. \\ Alfandegário: Como não tem?! \\ Entrevistado 2: (Gesto com a mão sobre onde estaria o rim.) \\ Meu rim, já foi. Meu pulmão, pro espaço. (Mão sobre o pulmão \\ e depois aponta para cima). Meu... (mão sobre a lateral da \\ barriga, não lembra a palavra) também foi (aponta para cima). \\ Dente, despachei. \\ (Alfandegário vai ficando cada vez mais surpreso.) \\ Alfandegário: (Quase desesperado) E o coração?! \\ Entrevistado 2: (Mão sobre o coração). O coração fica. \\ Alfandegário (aliviado): Pode ir.
}

Assim como nas narrativas de Paula, nessa cena também temos um diálogo que acontece em um tempo mais distendido, que pode ser visto como uma "barriga", mas talvez pela tensão da situação de uma inspeção alfandegária, ou pelo modo de os atores se expressarem, nos faz entrar em outra temporalidade. Assim, temos, nessa cena, além do tempo distendido das respostas, mais dois aspectos relacionados ao tempo: como tema no diálogo final (passa tempo, mata tempo, perder tempo) e na pausa longa que pontua esse questionamento. Cito aqui apreciações sobre o espetáculo que se relacionam às nossas propostas de invenção de sentidos poéticos, e às experimentações com o tempo, além de mostrar um pouco da diversidade de olhares sobre as cenas:

Uma das primeiras cenas apresenta, assim, a inspeção na alfândega da bagagem dos viajantes. Um ator chega com sua malinha: o funcionário abre-a e vai dizendo o que poderá ou não ser levado na viagem.

Os objetos mais simples - um desodorante, um livro, um sapato de cadarço, seja lá o que for - são confiscados do "viajante". Claro, depois de um tumor ou de um acidente, não sabemos mais o que teremos capacidade de manejar. Outras coisas - uma boneca, uma fotografia, uma relíquia do passado - serão, quem sabe, admitidas pelo arbitrário fiscal dessa nova e dura etapa da vida. A metáfora surge com humor e sutileza, 
porque apesar de tudo o "viajante" será aceito para entrar no barco ${ }^{42}$.

Fotografia 24 - Cena: Alfândega. Do outro lado do oceano - Ser em Cena, 2016

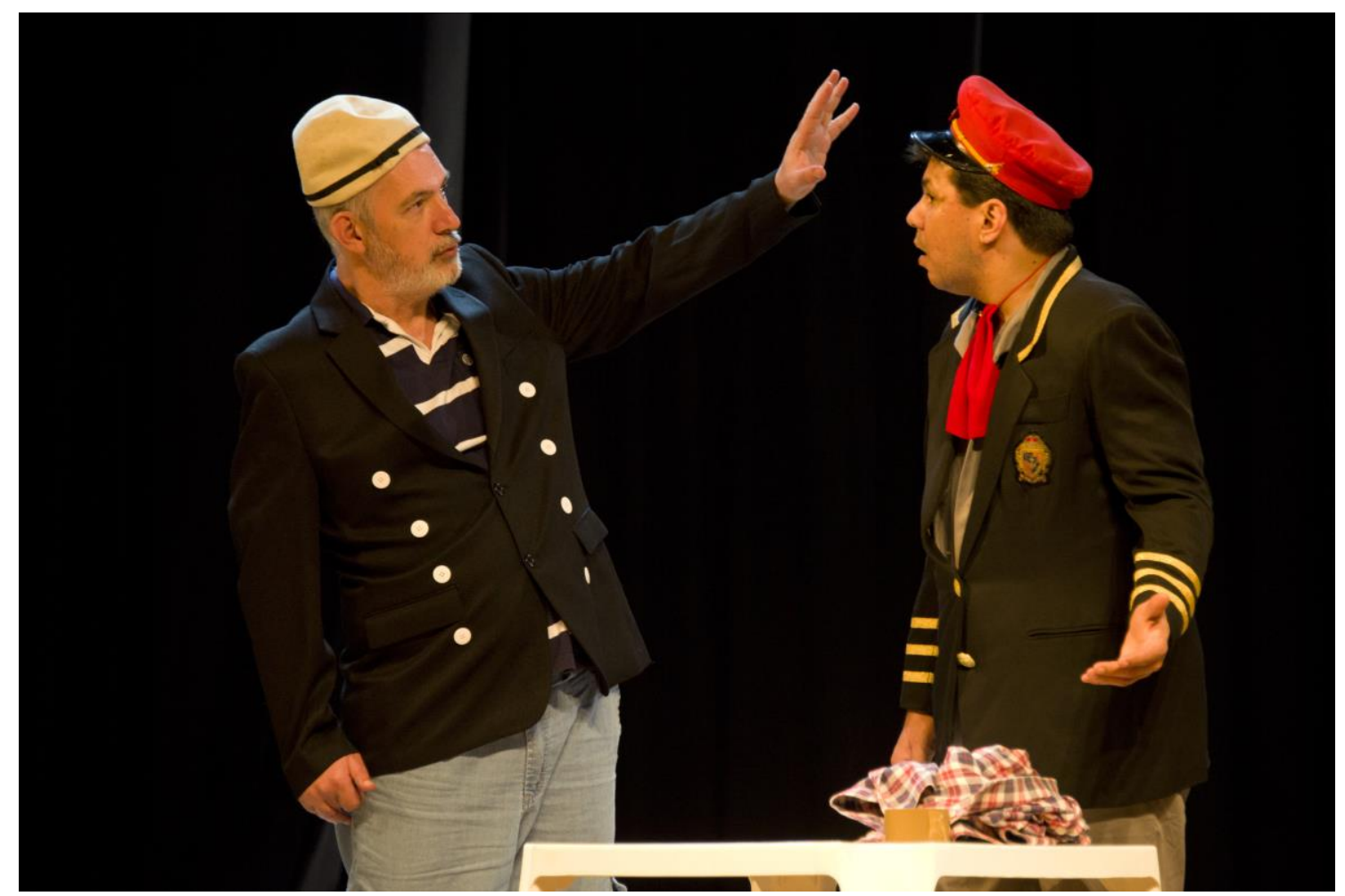

Ronaldo Serino e Michel de Affonseca e Silva. Foto: Karina Bacci.

Por mais que haja uma proposta de desfamiliarização, é inevitável que entre a diversidade de leituras surjam também relações com a condição da afasia do elenco, como podemos ver na leitura de Marcelo Coelho. Para algumas pessoas, essa camada de sentido relativa ao distúrbio da afasia reveste a cena de um aspecto relacionado à linguagem: algumas pessoas com afasia podem, por exemplo, esquecer o nome do filho ou não reconhecer uma imagem de um cachorro, mas continuar tocando saxofone ou dirigindo, de modo que os "objetos" ou palavras com que cada pessoa irá seguir adiante são os mais imprevisíveis.

Os movimentos lentos pareciam durar uma eternidade. Durou pouco a minha agonia, logo entrei no ritmo. Primeiro, temos que nos abstrair desse timing em que vivemos na sociedade moderna. Rapidez, velocidade, agito. Esqueça, crie

${ }^{42}$ COELHO, Marcelo. Atores com afasia mostram a difícil viagem da sobrevivência em peça. Folha Online, 21 dez. 2016. Disponível em:

<https://www1.folha.uol.com.br/colunas/marcelocoelho/2016/12/1843234-atores-com-afasiamostram-a-dificil-viagem-da-sobrevivencia-em-peca.shtml>. Acesso em: 9 jun. 2019. 
dentro de você um timing novo para ver o espetáculo. Esta foi a primeira lição que senti. A descoberta da existência de outro ritmo, outro tempo. Adapte-se a ele, vem uma sensação de paz interior.

No início, eu queria terminar as frases, errei várias delas, me envergonhei, ri de mim, porque os diálogos levam ao inesperado. Outra lição: não sabemos mais ouvir as pessoas, nos antecipamos, sôfregos, por quê? Para quêt ${ }^{43}$ ?

Esse trecho descreve um processo de abertura, ou experimentação de outras sensibilidades, por meio da fruição de eventos que acontecem em durações $^{44}$ diferentes daquelas a que estamos acostumados. Essa leitura também poderia servir a vários outros momentos de nossos trabalhos, que esgarçam, comprimem, dilatam o tempo, e nos transportam, junto com a cena, para outros modos de estar aqui e agora. Como a cena da deriva que relato a seguir.

\section{Deriva}

Em uma das improvisações para criação do espetáculo Finnegans Ueinzz, pequenos grupos propuseram cenas a partir da escolha de um lugar. Ana Gold, Fabricio e John ${ }^{45}$ criaram a seguinte cena: Fabricio está deitado no chão, com a cabeça apoiada na barriga de John, que também está deitado, ambos de barriga para cima. Ana, em pé bem atrás dos dois, mexe o corpo de modo que me lembra uma vela em movimento por causa do vento, e ela tem o rosto coberto. John e Fabrício improvisam um diálogo em que perguntam sobre comida, peixes e como eles chegaram ali. Eles repetem as perguntas com pequenas variações, e depois de algum tempo levantam e vão embora.

Chamamos essa cena de Deriva e a incluímos no espetáculo, com poucas mudanças da forma que surgiu. Em nossa primeira temporada, John aparecia entre o público (enquanto este esperava para entrar), começava a ler em voz baixa trechos do Finnegans Wake entre as pessoas e ia se direcionando para a área da performance, o que fazia o público segui-lo. Enquanto as pessoas entravam, Fabrício e Ana já estavam instalados no

\footnotetext{
${ }^{43}$ BRANDÃO, Ignácio de Loyola. Do outro lado do oceano. O Estado de S.Paulo, 14 abr. 2017, Caderno 2, p. C6.

${ }^{44}$ Para nossa análise, usamos a palavra duração no sentido do tempo que dura um silêncio ou uma fala.

${ }^{45}$ Ana Goldenstein, Fabrício Pedroni e John Laudenberger, performers.
} 
espaço cênico. John então se instalava em sua posição na cena. Ana falava baixo, de tempos em tempos, alguns trechos do Finnegans Wake. A maior parte da cena acontecia durante a entrada das pessoas. Quando o público estava instalado, os três performers desmanchavam a composição, indo embora um de cada vez.

Quando conversei com Ana para relembrar como essa cena foi criada, descobri (relembrei? reinventei?) que, para ela, inicialmente a situação era de um naufrágio no fundo do mar, e ela seria uma alga. Por algum motivo, talvez pelas falas do Fabrício ou a imagem que a cena sugeria, a cena foi "subindo", indo parar na superfície do mar, e se transformando na cena da deriva. O que víamos sugeria uma jangada, um náufrago e uma vela. Mas começou com um navio afundado, um náufrago e uma alga/água:

\begin{abstract}
Essa cena específica nasceu como um exercício. Você propôs que a gente se dividisse em grupos e definisse um lugar, não lembro se era você que definia ou se a gente definia o lugar [...] $\mathrm{E}$ a gente fez o fundo do mar, cada um decidia o que que ia ser, e a gente podia ser coisas que não humanos, isso era legal do exercício. O John falou "eu vou ser o navio", ele era o navio afundado, e eu estava no fundo do mar, mas não sei se o Fabrício achava que ele estava no fundo do mar. A minha movimentação era a partir do movimento da água, porque eu ficava balançando e era um movimento que exigia muito da coluna vertebral. [...] Tinha também alguma coisa de deserto, tanto o deserto do fundo do mar, o silêncio do fundo do mar e o silêncio de uma ilha deserta, de uma praia vazia, de uma coisa um pouco Beckett ${ }^{46}$, esperando chegar a comida, esperando ser resgatado. Eu me lembro que foi muito simples de fazer, o processo dela foi um exercício ${ }^{47}$.
\end{abstract}

Se conversássemos com mais pessoas sobre o surgimento da cena, provavelmente obteríamos mais versões diferentes desse começo. Nas tentativas de reconstituição, misturamos a memória do teatro (relembrar cenas antigas) e o teatro da memória (a memória é também recriação, interpretação, teatro $)^{48}$.

\footnotetext{
${ }^{46}$ Referência ao dramaturgo Samuel Beckett, expoente do teatro do absurdo, que criou peças como Esperando Godot, em que dois personagens esperam a chegada de alguém e dialogam enquanto esperam.

47 Trechos da conversa que tive com Ana Goldenstein para tentar relembrar como surgiu a cena da deriva.

${ }^{48}$ Esse tema poderia ser desdobrado em uma outra pesquisa que examinasse os modos com que a memória se constitui e a relação desses modos com procedimentos de criação teatral. Para maior aprofundamento, remeto o leitor ao artigo de Sérgio Zlotnic, "Palavra é lugar" (online, disponível em: <https://www.spescoladeteatro.org.br/noticia/palavra-e-lugar/>, acesso em
} 
Enquanto essa cena acontece, Onéss ${ }^{49}$ já esta deitado no chão perto de John, instalado para a cena do velório que aconteceria depois de mais duas cenas. Em Finnegans Ueinzz, o elenco está desde o começo do espetáculo em cena, sentados ao fundo do palco, do lado direito e esquerdo, e entram e saem "de cena" a partir das cadeiras. As cenas muitas vezes são montadas ou desmontadas durante a cena anterior ou seguinte, o que faz com que sempre existam figuras habitando o palco, muitas vezes como fundo, e que depois virão à frente. Essas transições podem ser claras, e outras vezes podem ser difusas, entrelaçadas com outras cenas.

Nesse revisitar dos cadernos e vídeos, lembrei-me de Renato Cohen, que sempre nos trazia o conceito de figura e fundo a partir da teoria da Gestalt, de modo que entendíamos o conceito a partir de uma apropriação e de experiência ${ }^{50}$. Herdamos marcas de Renato: não somente a relação figura e fundo, mas também o gesto de se inspirar em um conceito ou teoria livremente na criação de uma cena. É importante ressaltar que esse livremente não quer dizer de qualquer jeito: a cena tem sua coerência própria.

Nas temporadas seguintes, modificamos a cena e deixamos os três performers já instalados. Acrescentamos à fala de Ana (a vela) um parágrafo do Finnegans Wake. A sequência dos títulos das cenas estava escrita com giz na parede de onde acontecia o espetáculo. A cena era improvisada. Ana dizia o parágrafo entremeado pelas falas dos dois performers. Tudo era feito de forma sutil, minimalista, quase hipnótica; ao mesmo tempo era intensa, e ia aos poucos imantando o ambiente e trazendo as pessoas para a cena.

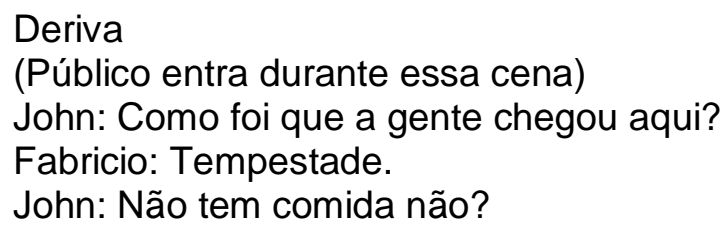

20 abr. 2020), a palestra de Peter Pal Pelbart sobre tempo a partir do minuto 42 (on-line, disponivel em: <https://www.youtube.com/watch?v=OJIWpsp2b6c\&t=264s>, acesso em 20 abr. 2020) e o livro de David Lapoujade Potências do tempo.

49 Onéss António Cervelin, performer.

50 "A forma de construção do espetáculo, apoiada na mise en scène e no imagético, faz com que o processo de construção seja gestáltico. Gestalt é forma, configuração. A performance remonta ao teatro formalista. O processo de criação geralmente se inicia pela forma e não pelo conteúdo, pelo significante para se chegar ao significado. Os conceitos de Gestalt passam a ser importantes no trabalho do encenador-performer. Trabalha-se com a transformação, com figura principal e com figura fundo. Num determinado momento o performer é frente, depois é fundo de um objeto, de uma luz etc." (COHEN, Renato. Performance como linguagem. São Paulo: Edusp/Perspectiva, 1989. p.106). 
Fabrício: Tem peixe.

John: Olha ali, tá vindo outra. Vamos embora?

Ana: Não dá.

John: Quero comida.

Fabrício: Vai pescar.

John: Como foi que a gente chegou aqui.

Fabrício: Há muito muito tempo.

John: Não tem comida não?

Fabrício: Tem peixe.

(Mais ou menos aqui o público está quieto)

John: Como foi que a gente chegou aqui?

Fabrício: Tempestade.

John: O que tem pra comer?

Fabrício: Tem peixe.

John: Tem molho de girassol?

Fabrício: Tem peixe.

John: Eu queria fazer uma bochecha.

Fabrício: Por que bochecha?

John: Com molho de girassol. Será que tem molho de girassol?

Fabrício: Será que dá pra gente sair daqui?

Ana: não dá. A gente está preso.

John: Quando foi que a gente chegou aqui?

Fabrício: Nesse momento.

John: Vamos embora?

Ana: Tá vindo outra. Ó, vocês estão vendo? Tá pra aquele lado. Depois vai passar. Vai desaparecer.

John: Como foi que a gente chegou aqui?

Fabrício: Há muito muito tempo.

John: Tem comida não?

Fabrício: Tem peixe. Tá vindo uma tempestade.

Ana: É lá de cima né? (Pausa) The cock striking mine, the stalls bridelly sign ${ }^{51}$.

Fabrício: O que ela tá falando?

John: Acho que é sobre comida.

Ana: There's Zambosy waiting for me! She said she wouldn't be half her length away.

John: Tem comida não?

Fabrício: Tem peixe.

Ana: Then, then, as son as the lump his back was turned, with her mealiabag slung.

Fabrício: Não tô entendendo nada que ela tá falando.

Ana: Over her shulder, Anna Livia, oysterface,

John: É sobre comida.

Ana: Forth of her bassein came.

John: Como foi que a gente chegou aqui?

Fabrício: Há muito muito tempo.

(Ana vai embora)

John: Tem comida não?

Fabrício: Tem peixe.

\footnotetext{
${ }^{51}$ Os trechos em inglês falados por Ana são fieis ao original de Joyce, com algumas palavras que ele inventou em seu léxico singular.
} 
Tenho um interesse especial por essa cena, pois ela funciona como uma câmara de despressurização para se entrar em outra atmosfera. Os três performers ficam o tempo todo na mesma posição: Fabrício e John deitados, e Ana de pé que, com os movimentos de tronco e braços, sugere pequena embarcação com uma vela, uma espécie de jangada com uma vela improvisada.

Fotografia 25 - Cena: Deriva. Finnegans Ueinzz - Cia Ueinzz, 2009

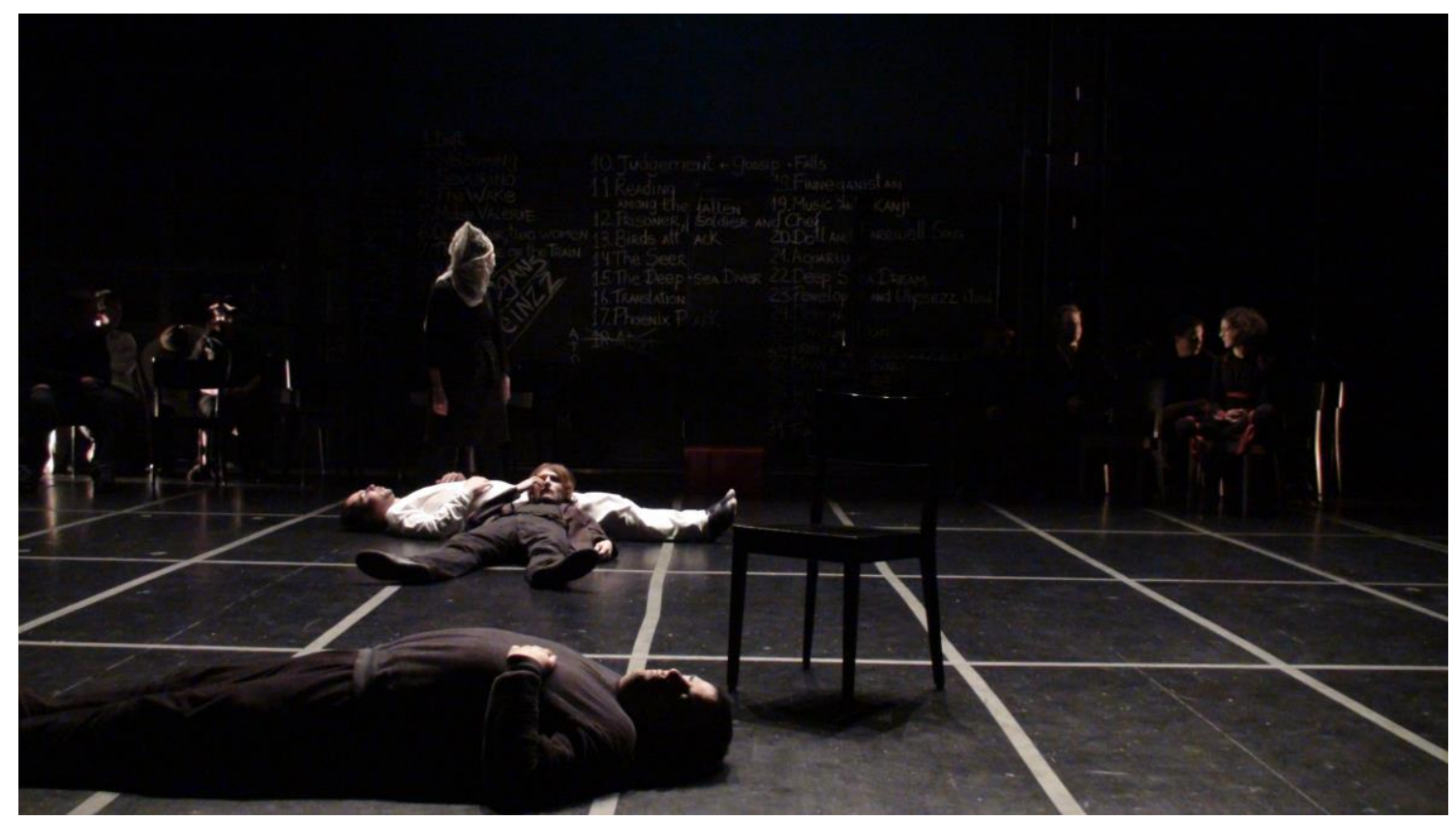

Do fundo para frente: Ana Goldenstein, Fabrício Pedroni, John Laudenberger e Onéss Cervelin. Foto: Simone Mina.

Falam sem pressa e com pausas entre as frases. Apesar da estrutura repetitiva do texto, não o fazem de modo mecânico ou automático: cada pergunta ou resposta têm uma certa intenção, que não chega a configurar personagens ou uma situação dramática, mas ao mesmo tempo não é o performer recitando um texto. Há também um contraste entre os movimentos abstratos e elaborados de dança da Ana e a coloquialidade de suas frases iniciais: "é, a tempestade tá vindo de lá, né?".

Também não considero essa somente uma cena de passagem, mas uma cena que começa durante a entrada do público, continua por uns quatro minutos depois que este se aquietou, e que o transporta para outro estado. $\mathrm{Na}$ temporada seguinte, experimentamos outra mudança: trazer a cena mais para "dentro" do espetáculo (que tinha 31 cenas). A Deriva passou de cena inicial para a quarta. Esse deslocamento intensificou a instauração de outro tempo, 
pois agora as pessoas viam toda a cena, que continuava com a mesma duração.

\section{Quase}

Acredito que uma chave do porquê essa cena funcionava é justamente por mostrar como às vezes podemos "desfuncionar". Ela abordava isso tanto no tema da deriva, quanto na sua forma errante de acontecer.

A deriva ${ }^{52}$ é um quase, é um círculo que não se completa, sem tempo e sem lugar. A deriva é uma fenda, é onde a existência está entre tudo o que ainda pode vir (o salvamento, a ancoragem, o naufrágio, o afogamento) e tudo o que poderia ter sido (outra rota, um caminho, a ancoragem, o naufrágio, o afogamento). É tarde. Não se sabe há quanto tempo estão ali, quanto tempo vão ficar e nem onde estão. Não há conflito, ou melhor, o conflito é sugado para dentro da deriva, o drama naufragou nos acontecimentos passados ou os aguarda no futuro incerto. Por hora, há o esgotamento em que os músculos, as vontades, os pensamentos e os conflitos habitam uma indeterminação que os leva a repetirem as mesmas frases, em um vácuo no qual não podemos mais falar em falta de vontade, pois a vontade também ficou para trás, quando ainda havia o conflito, ou ficará para a frente, quando e se algo acontecer. Importa agora essas pessoas e objetos (um náufrago, uma vela, um barco) que se perguntam continuamente sobre origem (como a gente chegou aqui?), alimento (o que tem para comer?) e desejos (estou com fome). Eles só repetem a pergunta e a resposta no meio do oceano cheio de peixes. Como nós muitas vezes patinamos em círculos, em pensamentos e comportamentos, formulando as mesmas perguntas, repetindo os mesmos atos de busca, as mesmas danças, os mesmos rituais e tentativas de autoconstrução, ou de individuação, ou de evolução, e não percebemos que são essas repetições que não só não nos levam a lugar algum nem nos fazem naufragar de vez, como perpetram indefinidamente a deriva da nossa existência.

\footnotetext{
52 Quando falamos de deriva, aqui, partimos da definição náutica do termo. De acordo com o Dicionário Básico Portuário em seu verbete DERIVAR: 1. Diz-se quando a embarcação se desvia da rota previamente estabelecida, por ação da corrente marítima. 2. Ação de navegar ao sabor dos elementos circunstantes como o vento, as vagas e a correnteza. 3. Andar à deriva.
} 
Quando consideramos em particular a questão do tempo na criação de cenas - como vimos nas narrativas de Paula; ou sobre a alfândega e o que se leva ou o que fica; ou então a dinâmica de fluxos que se atravessa em uma deriva - percebemos que também há o tempo de se relembrar essas cenas, ou atualizá-las no presente:

Quanto à atualização ela se situa sempre em outro nível; ela é parcial, descontínua e incompleta, visto que não pode fazer passar para existência o todo virtual copresente em cada ato. Nesse sentido, atualizar é sempre desacelerar, atrasar-se sobre os movimentos do espírito ${ }^{53}$.

Coincido com o objeto de estudo: os tempos distendidos das cenas também instauram um tempo distendido para que eu possa rememorá-las.

A rememoração desses eventos é "incompleta", "parcial" e "descontínua", mas ao mesmo tempo reinventa os acontecimentos na escrita dessa dissertação. Ao atualizar esses acontecimentos no tempo outro do agora (e que terá outros agoras nas leituras), também estamos reinventando futuros. Como naqueles experimentos da física, em que o olhar do observador transforma o experimento, esta escrita transforma o passado, presente e (acho que) futuro.

\section{SALA DE ESPERA DO VISTO}

\section{Línguas inventadas}

A: Ishclamim shinguiri namóitin, iláiscri, klãine lapontin, intrinem, trami, tin tin tom. Dilaplina, is trunglin. Tchegen. Is krindem, kraiden, kroiden, krundem.

B: Tata pokete patapatapa pepacá, pepacá, tapiqui, tantanpam, médio, médio ${ }^{54}$.

Existe um procedimento de teatro em que se pede para as pessoas falarem em uma língua inventada. Antigamente chamavam esse exercício de gramelô, hoje tem-se usado o termo fonemol. Para mim, gramelô já sugere um país com suas regras próprias, e fonemol parece um fármaco. Prefiro o termo língua inventada, em que cabem todas, inclusive a nossa.

\footnotetext{
${ }^{53}$ LAPOUJADE, 2017. P.121.

${ }^{54}$ Dois exemplos de línguas inventadas.
} 
Sempre experimento variações desse procedimento com os coletivos ${ }^{55}$ de criação, com respostas diferentes, e não é incomum que cause um desconforto inicial.

Em 2016, trouxe a proposta da língua inventada para as três turmas da ONG Ser em Cena: primeiro toda a turma fala ao mesmo tempo durante um minuto - descobrimos que fazer isso torna o exercício mais habitável. Depois experimentamos possibilidades: palestrante com tradução consecutiva para 0 português, contar uma história, dar aula, dar bronca, contar um segredo, declaração de amor. E principalmente diálogos em duplas, uma dupla de cada vez.

Uma das turmas aderiu ao procedimento de modo surpreendente. A maioria das pessoas se mostrou muito à vontade com o exercício. Fizemos de várias maneiras e abandonamos o tradutor e palestrante, pois muitas das pessoas têm dificuldade com o português, e se mostraram fluentes em suas próprias línguas. Algumas lembram a sonoridade árabe, europeia ou africana, outras têm fragmentos de palavras em inglês ou português, ou são um embaralhamento de palavras e expressões conhecidas. Mas mesmo nesses casos, o fato de o enunciado ser a invenção de uma língua, fez com que ficassem confortáveis dentro desse embaralhamento ou de outro uso das palavras, já que era a sua língua própria.

Quando falávamos nas línguas inventadas (que passou a ser uma prática frequente com essa turma), as pessoas acharam um lugar de vitalidade. Suas falas tinham fluidez, diferentes intenções, pausas. No caso dessas pessoas, o lugar de fala ${ }^{56}$ que lhes é reservado é restrito: há as sessões de fonoaudiologia e as tentativas de conversar com os outros. Em ambas situações, existe o prazer da superação, da melhora e da comunicação, mas ainda submetidos às dificuldades da constrição da língua "oficial".

"Desinstalado e desinstalando-se dos códigos estáveis da língua, sente-

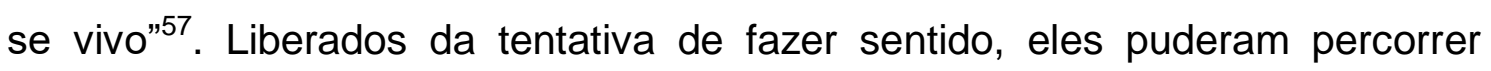
intensidades, libertar a língua e se libertar.

\footnotetext{
${ }^{55}$ Grupos, cardume, comunidade, turma, companhia, pessoas.

${ }^{56}$ É interessante pensar que esse termo também possa ser usado aqui como lugar de potência, mesmo sem o recurso da semântica. Como dar lugar de fala a pessoas que não falam linguagens "oficiais"?

${ }^{57}$ PRECIOSA, Rosane. Escrever/Balbuciar. Cadernos de Subjetividade, n. 12, 2010. p.88.
} 
Essa fluência acontecia de dois modos, que tinham suas diferenças mas também se atravessavam: havia um reencontro com a língua na sua forma pulsante, em um impulso anterior à gramática; ao mesmo tempo, um reencontro com melodias e cenas antigas, conversa, flerte, briga etc. ${ }^{58}$.

Decidimos inventar uma cena com essa turma, em língua inventada, no espetáculo que estávamos criando. $\mathrm{O}$ avesso do limite clínico emergiu como potência estética:

Aqui a precariedade de cada um dos participantes não é tomada como patologia a ser curada, mas como elemento de um processo vital de autopoiese, de autocriação, e, nessa medida, estético, que tem seus norteadores éticos na produção de diferenças e na busca de uma potência de vida ${ }^{59}$.

Discorri sobre como a criação de línguas é um recurso da linguagem teatral, dei exemplos de diretores que se serviram desse recurso (como Peter Brook ou Antunes Filho). Depois percebi que talvez estivesse falando mais para mim do que para a turma. Em nosso espetáculo seguinte, também havia uma cena com as línguas inventadas ${ }^{60}$. Não fiz essa prédica e a turma (que tinha então várias pessoas novas) ficou igualmente animada com a invenção de línguas e com a criação da cena.

\section{Na medida do impossível}

Em cada um de nossos processos de criação, convivemos com uma pergunta que pode ganhar mais relevância em alguns momentos, como quando estávamos considerando criar uma cena com as línguas inventadas. Como achar a medida entre expor (em um sentido de constrangimento) e legitimar outras existências, inventar novos modos? Não existe receita, é uma aposta, mas alguns indicadores ajudam nessa medida: 1 - $O$ prazer que as

\footnotetext{
${ }^{58}$ Sempre existem pessoas refratárias às propostas, e cada caso tem uma medida, de modo que podem ter pessoas que não fazem, ou experimentam um pouco, saem e voltam depois. Há casos que necessitam de uma pequena insistência de minha parte. Em outros, percebo que elas se aproximarão de acordo com o tamanho de sua vontade e de seu medo. Com cada pessoa vai ser um tipo de abordagem.

59 LIMA, Elizabeth Maria Freire de Araújo. Arte, clínica e loucura: território em mutação. São Paulo: Summus/Fapesp, 2009. p.223.

${ }^{60}$ Espetáculo Silêncios, moléculas, dinossauros, apresentado no Teatro Sérgio Cardoso em 2018 e 2019. A cena se chamava Tradutores do mundo inteiro se reúnem para comparar diferentes versões do livro, e também tinha o seu título anunciado durante a peça para se criar uma moldura ficcional.
} 
pessoas sentem durante o processo em fazer a cena ${ }^{61} .2$ - Minha experiência estética prévia (considerando estética no sentido dado por Rancière a essa palavra, de regime de visibilidades, mas também no sentido de gosto ou preferência pessoal). 3 - Minha experiência clínica prévia (não tenho formação terapêutica, mas posso falar no sentido de uma tentativa de escuta e olhar sensíveis ao que está acontecendo). 4 - Coeficiente de invenção: o quanto há de abertura e de possibilidades cênicas que fogem da herança do gosto. 5 - 0 nível de produção de espaços de vida e de vitalidade.

(Aqui falo em primeira pessoa, pois, seja como diretora, professora ou dramaturga desses coletivos, por mais que as decisões sejam tomadas entre a equipe que coordena ou mesmo entre o grupo todo, há uma responsabilidade individual, e cada pessoa, principalmente da equipe que coordena esses processos, deve conviver com essa pergunta.)

Mesmo considerados todos esses elementos na criação de uma cena, a recepção do público também vai ser heterogênea. No caso da criação dessa cena dentro da ONG Ser em Cena, são aproximadamente seiscentas pessoas que vêm assistir os espetáculos a cada vez que nos apresentamos ${ }^{62}$, portanto há todo tipo de gente e de fruição na plateia. Assim, a preocupação estética e ética, a ser considerada na criação de um espetáculo, que considera também o público, está mais relacionada aos nossos parâmetros de criação descritos anteriormente do que a alguma projeção de como seria esse público.

No caso relatado aqui, criamos a cena (descrita a seguir), e quando nos apresentamos, as pessoas do público de um modo ou de outro se afetaram: vieram me falar que adoraram, algumas ficavam sem saber o que achar (e vinham me perguntar porque é que eu colocava pessoas falando daquele jeito estranho), houve quem sugerisse que eu eliminasse a cena e quem falasse que essa era uma das melhores partes. Para além das reverberações do público, estávamos dentro dos indicadores descritos há pouco, e confiamos nisso.

\footnotetext{
${ }^{61}$ Não é um prazer absoluto, como se fosse uma aula de entretenimento, mas trata-se de perceber se há um impulso de vida que se sobressai ao incômodo inicial do exercício, ou se gera alegria, no sentido espinozano, que transforma e cria vitalidade.

${ }^{62}$ Estou desde 2016 com esse coletivo, e em geral fazemos anualmente duas apresentações no teatro do Sesi, que tem capacidade para seiscentas pessoas, ou no teatro Sérgio Cardoso, que comporta oitocentas pessoas.
} 


\section{Sala de espera do visto}

Para a criação da cena, decidimos colocar um título, o que conferiu uma moldura ficcional relacionada ao tema do espetáculo (uma viagem de barco). Essa moldura permitiu ao público entrar em contato com as intensidades das línguas instauradas, amparado pela ficção do título. No início da cena, o elenco estava sentado em cadeiras numa disposição que lembrava um cartório, ou repartição pública, e enquanto as cortinas se abriam, era anunciado em off: sala de espera do visto. Ali havia conversas, espera, flertes, resmungos, autoridade, reclamação, intenções desconhecidas, risadas, pedaços de frases etc. Para o público, é fácil reconhecer um lugar desses, mesmo sem entender a língua, e se identificar com a sujeição à burocracia quase infinita.

Fotografia 26 - Cena: Sala de espera do visto. Do outro lado do oceano - Ser em Cena, 2016

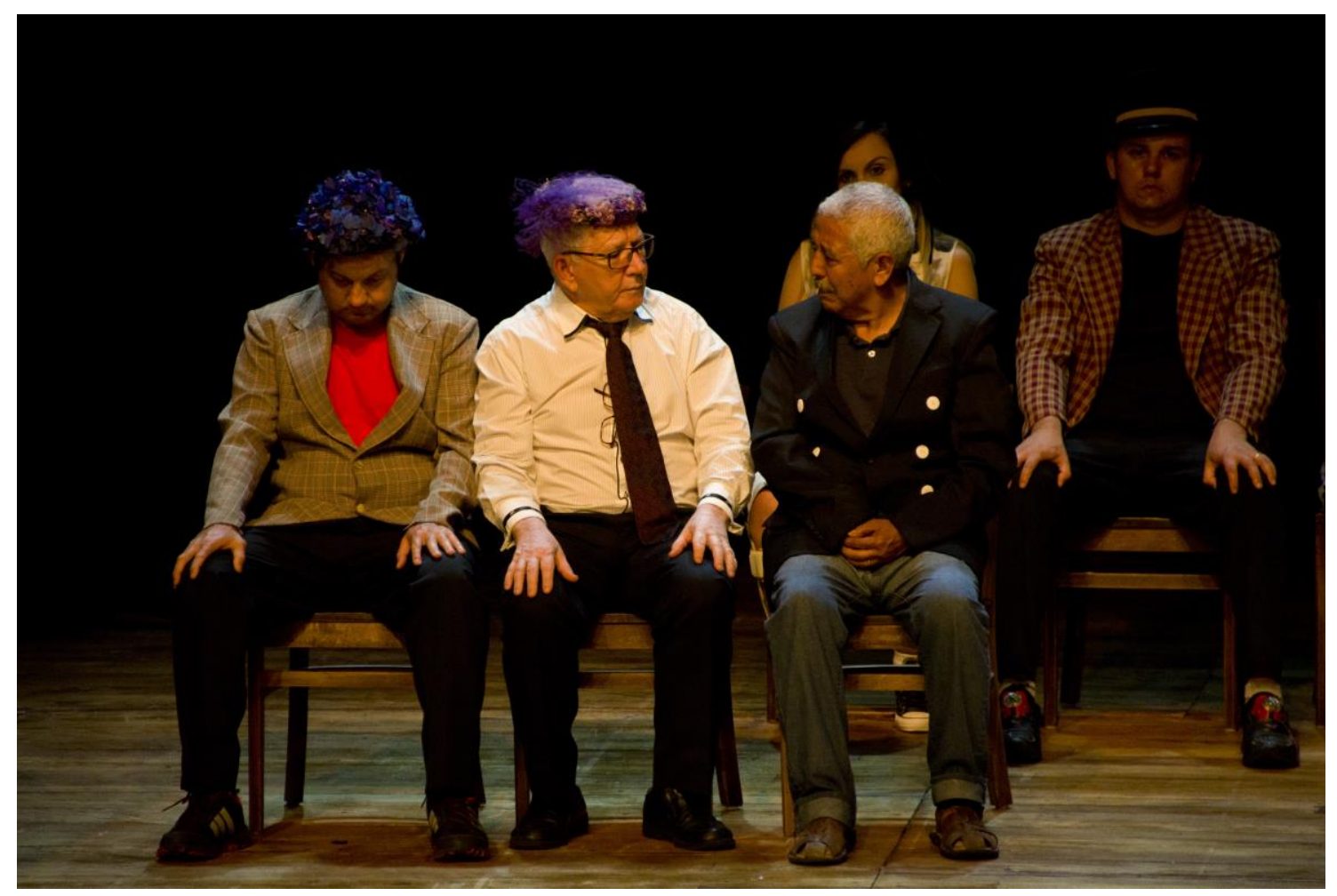

Da esquerda para direita: Fabrício Santos, João Correa, Sebastian Velasquez, Jennifer Pessanha e Michael Aguiar. Foto: Karina Bacci.

Na cena, havia uma camada estruturada (a ordem com que as pessoas falavam) e outra improvisada (a duração dos discursos). No aspecto improvisado, a duração de algumas falas poderia variar bastante, e decidi participar da cena, porque algumas vezes, no ensaio, essa variação fez com que a cena não acabasse nunca. Então eu intercedia (em língua inventada), 
jogando o foco para a próxima pessoa que falaria. Havia também um monólogo do Léo que terminava com "puta que o pariu". Às vezes ele esquecia esse xingamento final. Eu, sentada bem atrás dele, sussurrava pu... e ele se lembrava. Nas apresentações, não precisei interceder, o elenco estava afiado em suas marcações. Acho que eu quis participar dessa cena para poder inventar uma língua própria.

Fotografia 27 - Cena: Sala de espera do visto. Do outro lado do oceano - Ser em Cena, 2016

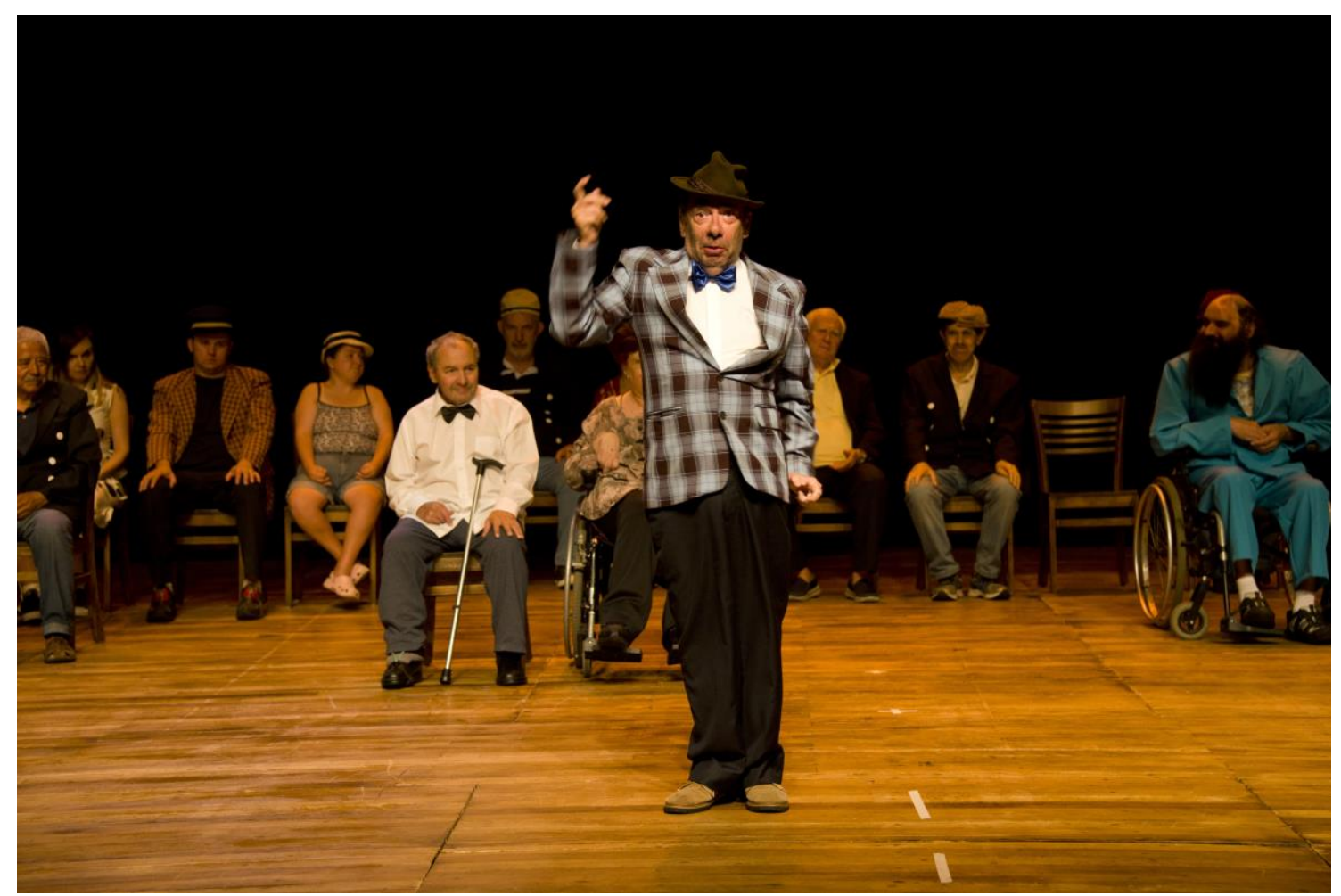

José Nelson e elenco da Ser em Cena. Foto: Karina Bacci.

Depois desse momento, Evelyn entrava como uma espécie de funcionária náutica e estabelecia um jogo com o elenco, de modo que, logo que ela aparecia, todas as pessoas da cena começavam a gritar e suplicar ao mesmo tempo, e quando ela parava (triangulando ${ }^{63} \mathrm{com}$ a plateia como funcionária sádica exercendo seu pequeno poder), silenciavam. Quando ela voltava a se mexer, voltavam os gritos, súplicas etc. Também aqui e ali escapavam vozes durante o momento de silêncio, que são bem-vindas para criar ruídos e tornar a cena menos "obediente" e mais viva.

\footnotetext{
${ }^{63}$ Termo do teatro em que um ator, antes de reagir a outro ator, olha com cumplicidade para a plateia, "triangulando" suas reações entre atores e plateia.
} 
Depois de fazerem esse jogo durante um tempo, entrava subitamente uma música cigana em que são cantadas as onomatopeias "tagaragaragaragara" ${ }^{4}$, enquanto Zé Nelson dançava e dublava essa voz (Zé Nelson é aquele com o corpo expressivo de um dançarino dos anos 1950, como é que eu posso descrever em um texto a beleza de uma dança?).

Havia uma pausa na música, em que Evelyn gritava: estão autorizados! Em seguida as pessoas começavam a dançar, jogavam os formulários para cima e faziam algazarra. Enquanto isso, um por vez, vinham na frente do palco e falavam o nome de um "país": Bauru, Afeganistão, Júpiter, vários México em sequência etc., e a cena dissolvia-se na dança geral.

A cena:

Joaquim: Meu coração é um pepino no meu coração, meu coração, nossa senhora, eu tô com um pepino aqui no meu coração... um problema, ai minha nossa senhora, meu coração, minha nossa senhora, assim não dá, meu deus do céu, pepino no meu coração! ${ }^{65}$

Armindo: Não, não é assim não, tem que ver ali, ali, mais em cima, mais para lá, mais embaixo, não é assim não.

Patrícia: Pi pi pi, pi pi pi pipipi pipipip pi pipipi pip! $!^{66}$

Léo: Patacão, patacão patacão, nheco nheco tagrágarágarágarágará. (discursa um tempo). Puta que o pariu. Maria Lucia e Onofre ${ }^{67}$ conversam: várias intenções, flertes, risadas, surpresa, divertimento.

Sebastian, João e Fabrício conversam, diálogo.

Armindo puxa o foco e joga para Roberto.

Roberto faz uma fala longa.

Celso e Patrícia conversam um pouco.

Evelyn chega, todos imploram ao mesmo tempo quando ela se movimenta. Quando ela para, todos congelam. O jogo se repete durante um tempo até ela sentar.

Começa música Fanfarre com gestos e dança de Zé Nelson.

Evelyn: Estão autorizados!

Todos dançam pelo espaço, cada um grita o nome de um país e sai do palco.

\footnotetext{
${ }^{64}$ É uma música do diretor sérvio Emir Kusturica que eu trouxe para o elenco ver como os recursos que tinham poderiam ser expressões artísticas, e essa música acabou entrando no espetáculo.

${ }^{65} \mathrm{O}$ que o ator tem: nossa senhora, pepino, meu coração. E o mundo é recriado com essas palavras. Essa fala é feita de uma mistura de palavras, que aumenta na fala do próximo ator, de modo que há um desmanche sucessivo do sentido.

${ }^{66}$ Patricia tem uma plasticidade sonora e mimética abrangente: esse discurso passeia por diferentes intenções e por várias oitavas.

${ }^{67} \mathrm{O}$ Onofre não fala quase nenhuma palavra em português, e quando faz esse exercício, faz monólogos que passam por diferentes intenções, risadas, pausas, diálogos com o invisível, broncas etc. É preciso dosar o tempo deles, e o meu, pois por mim o Onofre ou o Léo, por exemplo, poderiam falar por mais tempo na cena, mas temos outros 74 atores, o que me indica uma certa formatação de tempo nessa dosagem de experimentação que abra possíveis, mas não inviabilize.
} 


\title{
Existir mais
}

Apropriamo-nos de um recurso teatral e ele funcionou como um dispositivo de invenção de línguas, inventou artistas criadores que passam a "existir mais, mais intensamente, expandir-se, fazer existir ao seu redor outras existências" ${ }^{\prime 68}$. Esse dispositivo lida com instâncias que transbordam as da cena, legitima recursos pessoais, os transforma em linguagem. Para Lapoujade,

Mais uma vez, a legitimidade não mais repousa sobre um fundamento exterior ou superior, é cada existência que a conquista por um acréscimo da sua realidade. Ela é conquistada à medida que uma existência afirma e desvela sua arquitetura, se enriquece de determinações e ganha lucide ${ }^{69}$.

Criar condições para que essas falas pudessem existir deu a elas um acréscimo de sua realidade, que não estava repousada sobre fundamentos exteriores (uma gramática ou sonoridades a serem alcançadas), mas ganhou consistência pelos seus próprios fundamentos.

Acredito que a potência dessa cena está em nos conectar a alguma coisa viva, vibrante e sem nome. Ao entrar em contato com essas intensidades da cena, as nossas passam a reverberar em algum lugar.

\begin{abstract}
A partir de então, instaurar é como se tornar o advogado dessas existências ainda inacabadas, seu porta-voz, ou melhor, seu porta existência. Carregamos sua existência como elas carregam a nossa. Compartilhamos com elas a mesma causa, contanto que possamos ouvir a natureza das suas reinvindicações, como se exigissem ser amplificadas, aumentadas, enfim, tornadas mais reais. Ouvir essas reivindicações, ver nessas existências aquilo que elas têm de inacabado, é forçosamente tomar o partido delas ${ }^{70}$.
\end{abstract}

A autorização anunciada aos requerentes da sala de espera do visto também nos autoriza a sentir e perceber usos diferentes da linguagem (da língua e do teatro). Nessa instauração mútua, carregamos sua existência assim como elas carregam a nossa.

Lapoujade fala em "ver nessas existências aquilo que elas têm de inacabado". Inacabado pode ser uma linguagem que não tem o acabamento da

\footnotetext{
${ }^{68}$ PELBART, Ensaios do assombro. São Paulo: N-1 Edições, 2019. p.228.

${ }^{69}$ LAPOUJADE, 2017, p.91.

${ }^{70}$ Ibidem, grifo meu.
} 
gramática. Ou de uma existência que não tem o acabamento de um corpo que "funciona", ou de uma língua oficial. Por outro lado, o que não está acabado pode se transformar, contém virtualidades, está aberto a outras configurações.

Esse aberto que o elenco escancara com suas línguas inventadas não está sujeito às formas vigentes e constituídas, mas aponta para outros possíveis. Não se trata de ignorar o componente de sofrimento das pessoas que perderam seus recursos de linguagem, mas de poder ver quais outras identidades ou forças poéticas e políticas podem emergir desse inacabamento, sem restringir certas existências a uma única dimensão, a do sofrimento.

Ter que se reinventar aqui não é metafórico: as pessoas do elenco tiveram que mudar suas coordenadas e seu modo de vida de uma hora para outra. Para além da potência estética, essa cena dá mais margem de manobra a essas pessoas, encontra lugares de fluência, e é a vitalidade que surgiu na sua criação que transparece na cena.

Existe um costume inspirado na cabala judaica no qual, quando uma pessoa adoece, inventa-se um novo nome para ela, de modo que a morte, ao não encontrar a pessoa que veio buscar, vai embora de mãos abanando. Talvez as pessoas da sala de espera do visto, ao inventarem suas línguas próprias, também fiquem um pouco mais fluentes em jeitos de enganar a morte. E nós, quando estamos na sala de espera do visto (como artistas ou público), percebemos que "o outro não é apenas o dessemelhante - 0 estrangeiro, o marginal, o excluído - é também uma sensação de incompletude que nos mantém em suspenso, como inacabados, na espera de nós mesmos" ${ }^{\prime 11}$. Olhar para essa cena também pode mostrar em nós, o que temos de inacabado, e quais línguas podemos ainda inventar.

\section{MÁQUINAS DE TEMPO}

De acordo com Suely Rolnik, em seu livro Esferas da insurreição - notas para uma vida não cafetinada, entre as diferentes forças e formas de vida, há uma instância que são os fluxos, as forças que agem e nos atravessam, os mundos por vir que pedem passagem, e essa instância, pura pulsão de vida, é

\footnotetext{
${ }^{71}$ MEDEIROS, Virginia de apud PELBART, Ensaios do assombro, p.228.
} 
desagregadora porque não se fixa em uma forma. Ela descreve também outra instância, que é a forma, a tendência à permanência e ao consolidado.

Suely Rolnik nos aponta a importância de se reconhecer esses dois aspectos: se, por um lado, as pessoas ficam com medo de se desorganizar demais, tentando abafar a parte pulsional, tornam-se reativas ao invés de ativas. Se, por outro lado, se permitem ser atravessadas por esses incessantes mundos em criação, têm que inventar novas formas para "renomear, sentir e perceber o mundo"72. Não há síntese entre esses dois aspectos, mas uma

[...] tensão entre, de um lado, o movimento que pressiona a subjetividade na direção da conservação das formas em que a vida se encontra materializada e, de outro, o movimento que a pressiona na direção da conservação da vida em sua potência de germinação $[\ldots]^{73}$.

Cada processo criativo tem suas especificidades: a linguagem escolhida, as coordenadas coletivas, o lugar onde acontecem os encontros, o tempo disponível, as características de cada pessoa e do grupo, etc.

O curso de performance do Programa Igual Diferente, do MAM, acolhe pessoas em seus mais "diferentes modos de estar no mundo" 74 , e procura dar condições para que essas pessoas se tornem criadoras. É um lugar de experimentação estético-clínica, de modo que os desejos e possibilidades do coletivo determinam quando e como os recortes dos processos criativos são realizados; ou seja, podemos definir a linguagem (performance, experimento cênico, publicação), a duração e a periodicidade das aberturas e compartilhamento com o público.

Algumas vezes, essa aposta faz com que seja preciso que o coletivo recrie seus próprios meios de expressão, ao se "buscar entender por onde a vida quer se criar e explorar outras possibilidades de conexões, compreensões e criações" ${ }^{\prime 75}$. Em 2019, a heterogeneidade do coletivo do curso de performance foi tão intensa que nos reinventamos para achar uma forma que

\footnotetext{
72 PRECIADO, Paul B. Prefácio. In: ROLNIK, Suely. Esferas da insurreição: notas para uma vida não cafetinada. São Paulo: N-1 Edições, 2018. p.18.

${ }_{74}^{73}$ ROLNIK, 2018, p.56.

${ }^{74}$ LEYTON, Daina. Asas para um desejo. In: Educação e acessibilidade: experiências do Museu de Arte Moderna de São Paulo. São Paulo: Museu de Arte Moderna de São Paulo, 2018. p.157.

${ }^{75}$ Ibidem, p.157.
} 
organizasse e abarcasse esses "mundos que pedem passagem"76, relatados a seguir.

No meio do ano, em uma das visitas que fez para fotografar a nossa turma, Karina Bacci, que também é professora de fotografia do Igual Diferente, fez um comentário que se aproximou de um diagnóstico: vocês conseguem transformar o caos em poesia. Não era caos no sentido de uma entropia total, mas é uma palavra que, para quem está de fora, pode descrever um pouco a sensação que se tinha em alguns momentos mais farfalhantes dos nossos encontros durante aquele ano. Como artistas e educadores, eu e Leonardo Castilho (que ministra o curso de performance junto comigo) temos experiência e uma certa margem de manobra para permitir que os corpos existam e se expressem em suas diferentes vibrações, e ao mesmo tempo também mediamos negociações que podem ser verbalizadas ou implícitas, corporais e afetivas, para estabelecer um diapasão coletivo que comporte essas diferenças.

Entre a nossa diversidade, havia dois participantes que naquele ano se encontravam em períodos mais agitados de suas vidas, trazendo outros ritmos e demandas para nossas dinâmicas, o que instaurou no resto do coletivo uma sensibilidade e um cuidado especiais para lidar com essas presenças.

Por um lado, isso gerou um engajamento forte de acolhimento e sustentação de todo o grupo, mas criava uma situação em que sempre havia a possibilidade de uma interrupção - o que aconteceu algumas vezes e fazia com que um de nós parasse o que estava fazendo para lidar com uma demanda específica. Especialmente com essa turma, além de mim e do Leo, outras pessoas do coletivo se dividiam nessas atenções.

Também havia uma flutuação da presença de alguns participantes que vinham de outra instituição; outros, com locomoção reduzida, tinham dificuldade com o transporte. Alguns eram assíduos, outros vinham de vez em quando. Essas especificidades exigiram uma mudança de rota e um esforço não somente nosso, dos professores, mas de toda a turma: se por um lado foi mais imprevisível, por outro gerou uma maior adesão coletiva para lidar com as variações.

\footnotetext{
${ }^{76}$ ROLNIK, 2018.
} 
Durante o ano criamos algumas cenas, improvisos, performances; e em meados do segundo semestre, tínhamos acumulado bastante material cênico. Quando começamos a imaginar um roteiro, percebemos que uma apresentação cênica não seria o melhor formato, pois o grau de entropia e improviso era maior do que a possibilidade de fixação. Os "mundos que pedem passagem" eram mais fortes do que a sua fixação em formas.

A forma de finalização das nossas atividades varia, e não há uma demanda exterior por produção cênica ao final do ano, mas tínhamos acumulado um material criativo potente e diversificado, e seria importante para nós encontrar meios de elaborar e metabolizar essas criações, descritas a seguir.

\section{Máquina do tempo}

Quando visitamos a exposição Sertão, em cartaz no MAM, uma obra chamou nossa atenção. Fui criado entre máquinas e fogo, do artista Randolfo Lamonier, era uma espécie de geringonça suspensa cheia de objetos antigos, plantas, luzes, uma minúscula TV, bichos de plástico etc. Conversamos sobre a obra, com a mediação de Laysa Elias, que faz parte da turma de performance e também é educadora do museu. Alguém comentou que parecia uma máquina do tempo, e resolvemos criar a nossa própria.

Nos encontros seguintes, trouxemos objetos de tempos diferentes (luzinhas de natal, bonecas, cacarecos antigos, espelhos, fitas VHS, faixa de miss etc.), e também colecionamos objetos do ateliê onde acontecem os encontros, como espelhinhos e bolas coloridas, o que resultou em nossa própria máquina do tempo: uma instalação-dispositivo, geradora de cenas e improvisações.

Um dos elementos da máquina era uma coleção de fotos antigas, em preto e branco, que Laysa achou na rua. Nossa máquina era feita de tempos sobrepostos: a vida de uma família dos anos 1950, projetadas por meio de um retroprojetor dos anos 1980, sobre objetos de diferentes décadas dos séculos XX e XXI. Essa máquina foi remontada pelo grupo algumas vezes, e em cada encontro ela "saía" de um jeito. Experimentávamos camadas: a montagem da máquina, a disposição das fotos e objetos escolhidos a cada dia, as diferentes possibilidades de relação dos nossos corpos com as projeções das fotos no 
espaço e as diferentes improvisações que surgiam. A máquina do tempo também era uma máquina de cenas: cada dia íamos parar em um lugar.

\section{Calendários}

Olivia tem uma relação muito próxima com datas e calendários. Muitas dessas datas são ligadas a um nome e/ou um acontecimento. Por exemplo o 27 de maio de 2012, que a llka estava estranha de coque com boca de china, o dia da escrivaninha, o 10 de novembro de 2016 que foi o dia do brigadeiro, que não é o 10 de maio de 2012 que foi o dia do não desculpo. Ela costuma dizer essas datas nos encontros, ou escrever em um papel, ou me mandar por WhatsApp.

Ela também cria perguntas a partir das datas, por exemplo: "Elisa no dia 22 de abril de 2011, você me amava? Quantas terças-feiras existem? O dia 22 de maio de 2012 foi antes ou depois do dia 14 de junho de 2009?".

Em 2019 as suas datas estavam habitando os nossos encontros mais intensamente, e era frequente suas perguntas aparecerem nas atividades, sejam elas quais fossem. Um dia as perguntas estavam surgindo sem parar.

Esse foi para mim um momento de mudança: como acolher o desafio? Como lidar com seu fluxo sem nomear como ruído, ou incômodo, mas inventando algum jeito de dar conta? Eu tentei olhar para esse excesso sem ser refratária ao que ela estava trazendo. O elemento de instabilidade que ela trouxe foi então metabolizado em criação: a partir das suas datas, sugeri que criássemos os nossos próprios calendários, inspirados no dela.

Cada um inventaria uma data com um título e um gesto para essa data. Muito depois desse dia, percebi que essa ação coletiva é um desdobramento, ou equivalente, das dinâmicas em que as pessoas improvisam a partir do corpo, deixando os movimentos de umas contaminarem as outras, que podem repetir ou transformar com o corpo o que veem, e nesse fluxo entram todo tipo de movimento, pausas, mudanças bruscas, rodopios, às vezes sons, às vezes perguntas.

Transformar essa particularidade em exercício coletivo deu uma nova potência para o grupo e gerou, em Olivia, um engajamento que eu nunca tinha visto. Ela faz os exercícios do seu jeito, que é único, e pode ser bem diferente do que foi proposto. Outras vezes ela pode não querer fazer o exercício e ficar andando, deitada, ou prestando atenção em outra coisa. No dia da criação das 
datas de cada pessoa, ela fez o exercício proposto várias vezes, seguindo as regras, podendo dar vazão à sua intensidade daquele dia, e inspirando outras pessoas do grupo.

A sua característica se transformou em uma gramática poética: criamos os nossos próprios calendários e experimentamos várias formas de relacionar e misturar os calendários de cada um: 1) todos se colocam na "máquina do tempo", e uma pessoa por vez sai de lá e faz sua data pelo espaço; 2) cada um escolhe um lugar no espaço para "fazer a sua data" (nomear um dia e fazer um gesto para esse dia), e depois, quem quiser vai nos espaços dos outros fazer as datas dos outros; 3) todos pelo espaço formando sobreposições, por exemplo, o dia que nasci peixe, o dia do debutante não desculpo etc.

\section{Língua de sinais performática}

Investigamos o potencial performático da língua de sinais, ou libras: a partir de algumas palavras em libras ensinadas pelo Leonardo Castilho, experimentamos transformar a palavra sinalizada em um movimento do corpo todo, ou então misturar gestos das libras a partir da combinação de duas ou mais palavras.

É difícil descrever o potencial poético desse exercício: ao misturar, por exemplo, o gesto da palavra ontem (Léo também nos trouxe palavras relativas ao tema do tempo que foi se instaurando) e da palavra cachorro, criávamos um equivalente corporal de um neologismo feito dessas duas palavras: cachorro + ontem. Experimentamos algumas vezes a invenção de novas palavras-corpo, e esse procedimento sempre gerava bastante animação: as pessoas riam, se divertiam, se enxergavam mais, e seus ritmos variados imantavam o espaço.

Além dessas cenas, tínhamos outras, criadas em improvisações, que foram constituindo nossa "coleção" cênica. Algumas tinham nome, outras tinham o nome dos que participavam dela. Todas essas cenas foram sendo escolhidas por mim, Léo e pelas pessoas do grupo que queriam repetir determinada cena ou improvisação.

Mesmo sem ter um conteúdo reconhecível (como um enredo, situação ou personagens), elas continham um acontecimento e uma densidade própria. Algumas eram mais estruturadas, outras variavam dentro de um tema ou mote corporal: Barbie quer ser um cachorro, Línguas inventadas, Andrea e Dersu, Órbitas, Consolação, Ale e Léo, Expressões em duplas. 
Com todo esse material na mão, estávamos em um impasse. Como conciliar as oscilações da turma e os atravessamentos que aconteciam a cada dia com a estruturação de uma sequência de cenas a serem apresentadas? Novamente, eu sentia uma sensação de desmanche ao mesmo tempo que tentava imaginar possibilidades. Era importante fazer alguma coisa com a nossa coleção de experimentos e cenas. Não se tratava da busca por um produto a qualquer custo, the-show-must-go-on, mas da necessidade de dar um corpo coletivo a essas invenções que tomavam forma (ainda que mudando suas formas a cada dia, mantinham uma consistência dentro da variação).

Como imaginar estratégias coletivas que dessem conta das intensidades dos nossos encontros? Como achar uma forma para nossas criações? Às vezes parece que para uma coisa nascer outra precisa se tornar impossível. Em outras palavras, a impossibilidade de ir por um certo caminho pode fazer com que se invente outros.

Novamente o diálogo com Suely Rolnik nos ajuda a esmiuçar os impasses daquele momento:

\begin{abstract}
O que orientará o desejo em seus cortes, nesse caso, é a busca de uma resposta ao ponto de interrogação que se colocou para a subjetividade ao se ver destituída de seus parâmetros habituais. Em suas ações, ele se conectará com pontos inabituais da superfície para fazer seu corte, buscando vias de passagem para a germinação e o nascimento do referido embrião de mundo que habita silenciosamente o corpo [ou ruidosamente, como no caso do nosso corpo coletivo]. A atualização desse mundo em estado virtual que seu gérmen anuncia se efetuará por meio da invenção de algo - uma ideia, uma imagem, um gesto, uma obra de arte, entre outros [...]. Seja qual for esse algo, o que conta é que ele carregue consigo a pulsação intensiva dos novos modos de ver e sentir - que se produziram na teia de relações entre os corpos e que habitam cada um deles singularmente -, do modo a torná-los sensíveis, promovendo desvios na superfície do mundo ${ }^{77}$.
\end{abstract}

Durante esse período, Gregório Sanches, educador e coordenador do Programa Igual Diferente, vinha filmando alguns de nossos encontros para fazer experiências de imagem, e no decorrer de suas visitas, a turma foi se sentindo à vontade com a presença da câmera; também em alguns dos encontros assistimos a essas experiências, de modo que fomos nos aproximando desse universo. Uma frase de Greg em nossas conversas me

\footnotetext{
${ }^{77}$ ROLNIK, 2018. p.60.
} 
marcou: a sua ideia, com as filmagens, era captar não o acontecimento, mas a potência do acontecimento. A ideia de experimentar o formato do vídeo para lidar com nosso material surgiu quase como um encaixe, um desdobramento do nosso fluxo.

Pensando no diálogo entre o processo estético e o terapêutico, a linguagem do vídeo tem uma poética que incorpora o imprevisto e a flutuação de um modo mais adequado que uma apresentação cênica (no caso do nosso processo de 2019).

Mudamos a rota e começamos a rever o nosso material à luz dessa linguagem. Passamos a lapidar e desenvolver nosso arcabouço criativo imaginando um roteiro de filmagens, e a novidade, abertura e instabilidade desse campo, inaugurava potencialidades diferentes das que vínhamos experimentando em nossas performances durante esses anos.

No vídeo, as cenas poderiam ser pensadas separadamente, e o ângulo de visão dessas cenas, decidido por nós, o que abre um campo imenso de possibilidades. Também seria possível editar o andamento das cenas. Era uma sensação de medo e liberdade, de criar a cartografia enquanto se experimenta um território novo, no qual é possível direcionar o olhar e editar o acontecimento.

Marcamos um dia de filmagem com o roteiro das cenas e improvisações que queríamos fazer. A filmagem permitiu que lidássemos com o que foi repetido durante o processo, e ao mesmo tempo incorporássemos variações do momento.

Também permitiu pensar nos nossos materiais de modo independente, como partes a serem entrelaçadas na edição. Deu tempo de fazer quase metade do planejado. Marcamos uma segunda diária de filmagem e fizemos mais uma parte, novamente desapegando de cenas que não iríamos conseguir fazer (pois não iria dar tempo de filmar tudo o que imaginamos), tentando impor silêncio no set, o que em alguns momentos poderia se tornar quase uma missão impossível, mas também acolhendo a luminosidade de cenas-surpresa.

A Laysa também trabalha com vídeo e nos ajudou a realizar as filmagens, além de editar o material, o que fez muita diferença. Sua presença no curso foi importante, funcionando como um eixo de suporte e interlocução prático e criativo a esse mundo das imagens. 
Há uma frase de Joseph Campbell que diz "onde você tropeçar, aí reside o seu tesouro"78. Não acredito nesses manuais que nos tiram o direito até de tropeçar. Às vezes um tropeço é só um tropeço. Mas nesse caso, Campbell estava certo. A mudança de rota foi frutífera e engendrou um desejo de novas experiências.

Algumas cenas foram acidentalmente apagadas e infelizmente não entraram no filme, poderíamos ter pensado em mais diárias de filmagem, ou até em futuros processos em que a filmagem e a edição do material fossem feitas também pela turma. Esses "desacertos" apontam para outros inícios, em que poderemos desdobrar as possibilidades do vídeo.

Felizes com a possibilidade de dar corpo às nossas invenções e achar jeitos de fazer caber as imprevisibilidades e os atravessamentos, assistimos juntos, em uma sessão no MAM, comendo pipoca, o nosso filme Lembrar não é acontecer $^{79}$, nomeado com uma das frases de Olivia.

Nas entrelinhas da produção de um filme, para dar conta das demandas e da intensidade do nosso processo, criamos uma rede de apoio e de sustentação, criativa e clínica, na qual

[...] o que importa aqui não é unicamente o confronto com uma nova matéria de expressão, é a constituição de complexos de subjetivação: indivíduo-grupo-máquina-trocas múltiplas, que oferecem à pessoa possibilidades diversificadas de recompor uma corporeidade existencial, de sair de seus impasses repetitivos e, de alguma forma, de se ressingularizar ${ }^{80}$.

Para recompor a nossa "corporeidade existencial coletiva", inventamos um filme, mas também inventamos outros modos de estar em um coletivo e de ser um coletivo. Nossa máquina do tempo também nos levou aos outros tempos de criação do vídeo, a máquinas de tempos que se equilibram entre as instituídas formas do mundo, e as "forças que o agitam, desestabilizando sua forma vigente" ${ }^{\mathrm{N1}}$ e criando outras.

\footnotetext{
${ }^{78}$ CAMPBELL, Joseph. A Joseph Campbell companion: Reflections on the art of living. Joseph Campbell Foundation, 2011. p.12.

${ }^{79} \mathrm{O}$ vídeo pode ser visto no Youtube: <https://www.youtube.com/watch?v=4gKI7gBiZ24>. Acesso em: 20 abr. 2020.

${ }^{80}$ GUATTARI, 1992, p. 17.

${ }^{81}$ ROLNIK, 2018. p.49.
} 


\section{LONGÍNQUO}

\section{O longínquo do outro e os outros de si}

Alguns dos dispositivos que utilizamos em nossos coletivos para a criação de outros de si, assim como diferentes entendimentos do enunciado, colaboram na instauração de uma linguagem própria. Essa linguagem valoriza "modos de existência distintos dos hegemônicos" promover aberturas e inventar outros possíveis, promovendo uma "redistribuição do sensível"83.

Ter consciência das diferentes camadas que compõem a espessura artística de uma obra é importante, pois "política e arte, tanto quanto os saberes, constroem 'ficções', isto é, rearranjos materiais dos signos e das imagens, das relações entre o que se vê e o que se diz, entre o que se faz e o que se pode fazer" ${ }^{\prime 4}$. Em épocas de turbulência política e social, em que há, muitas vezes, a tentativa de apropriação da arte para discursos moralizantes e cerceamentos ideológicos, esses rearranjos das relações também se dão entre quem vê e quem pode ser visto.

A busca por uma estética em trabalhos com aspectos sociais é também um gesto político ao ampliar as possibilidades de entendimento e fruição do que é belo. Assim como a dança moderna foi considerada uma aberração, uma deformidade para os critérios do império do balé clássico, quem sabe quais outros critérios e quais outros tipos de beleza podem surgir a partir dos corpos diferentes que participam de uma criação artística ${ }^{85}$ ?

Um dos procedimentos que utilizamos em nossos processos criativos é evidenciar as idiossincrasias, de modo a abrir uma clareira expressiva, colocar em foco algo que surgiu como um desvio, ou "erro" de entendimento do

\footnotetext{
${ }^{82}$ Ibidem, p.141.

83 RANCIERE, The Aesthetic Today. Palestra proferida na Yale School of Arquitecture de 2016 [on-line]. Disponível em: <https://www.youtube.com/watch?v=w4RP87XN-dl>. Acesso em: 1 jun. 2019.

${ }^{84}$ Idem, A partilha do sensível. São Paulo: Editora 34, 2009. p.59.

${ }^{85}$ Não estamos falando aqui em um sentido de superação, como se houvesse uma linha evolutiva em que uma corrente (dança moderna) seria mais evoluída do que outra (balé clássico), ou uma visão de mundo estivesse sendo aberta, num sentido progressista, mas colocamos esse exemplo para perceber o momento de descolamento de uma gramática homogeneizante, como o repertório de gestos do balé para uma composição estéticoexistencial mais heterogênea. Ainda assim, a dança moderna cria uma nova codificação. $O$ nosso exemplo serve para ilustrar como, ao experimentar novas coordenadas, não podemos nos guiar pelas antigas.
} 
enunciado, como nos casos da criação das cenas Mdse. Valerie, Paquita ${ }^{86} \mathrm{e}$ Matadores de $u_{r u b u^{87}}$, que analisaremos a seguir.

Fotografia 28 - Finnegans Ueinzz - Cia Ueinzz, 2009

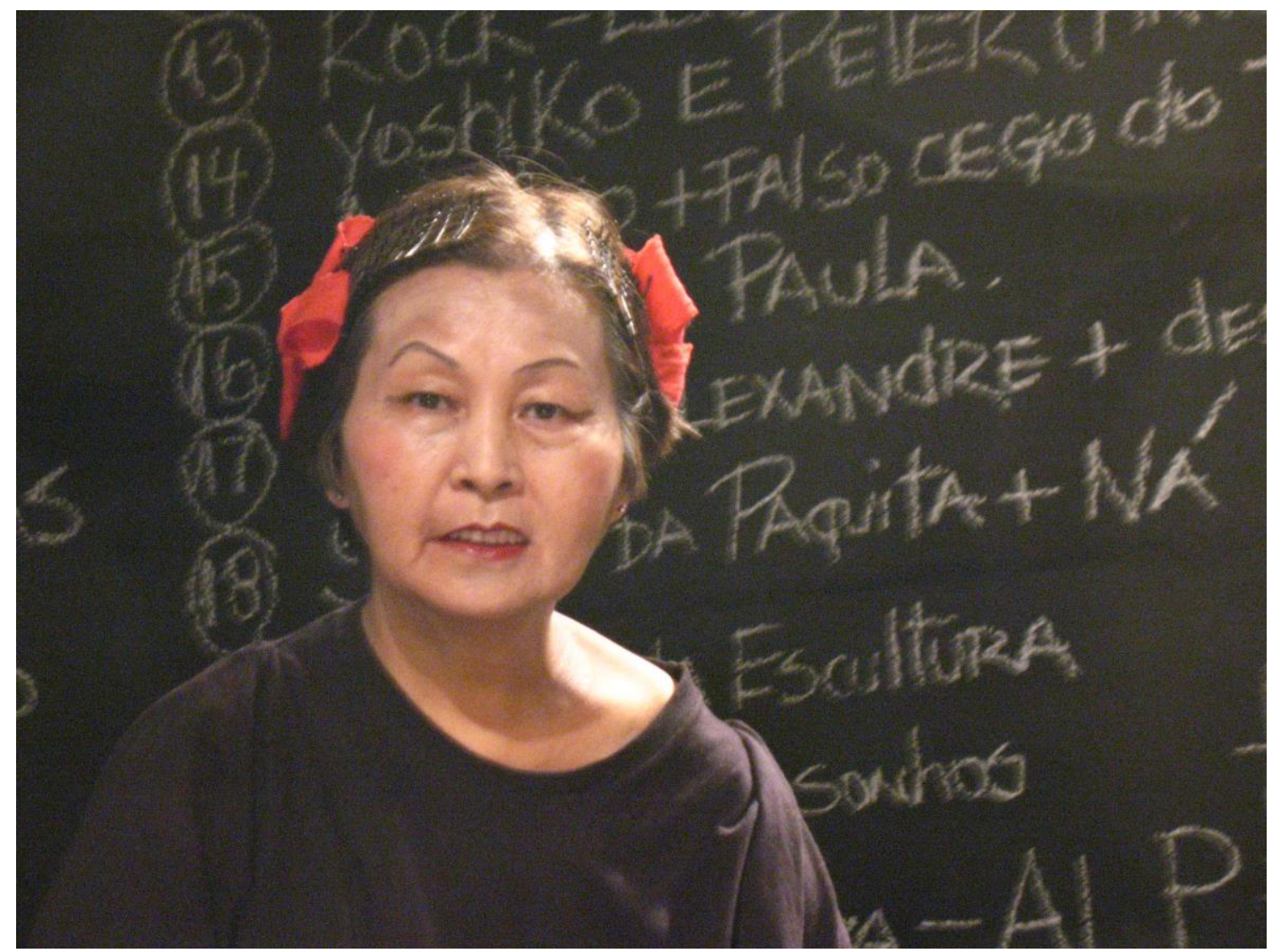

Yoshiko Minie. Foto: Simone Mina.

Em 2009, criamos o espetáculo Finnegans Ueinzz a partir da obra Finnegans Wake, de James Joyce. Assim como a narrativa de Ulisses - outra obra do mesmo autor - acontece durante o percurso de um dia, a proposta de James Joyce é que Finnegans Wake seria a noite desse dia.

Partimos do mais simples: o que acontece à noite? As pessoas sonham. Pedimos para as pessoas do elenco narrarem seus sonhos, e a partir disso realizamos algumas formas de dispor essas narrativas no espaço e no tempo.

Optamos pela seguinte forma: várias pessoas realizam as narrativas simultâneas enquanto saem do fundo do palco e caminham em direção à plateia, espalhando-se e criando múltiplos focos, uma polifonia em que se ouvem trechos das narrativas, dependendo das posições das pessoas do

\footnotetext{
${ }^{86}$ Espetáculo Finnegans Ueinzz, com a Cia. Ueinzz.

${ }^{87}$ Espetáculo Silêncios, moléculas dinossauros, com o grupo de teatro da ONG Ser em Cena.
} 
elenco e do público, e da intensidade da voz que pode aumentar ou diminuir de acordo com a narrativa.

Nos coletivos descritos neste estudo, não há uma separação rígida entre ensaio, aquecimento, improvisação ou laboratório, que se embaralham e se contaminam dependendo do que surge no dia. Existem planos e propostas, por exemplo, de aquecimento, mas de dentro do aquecimento pode surgir um gesto ou um movimento tão particular que muda o percurso do encontro, e de repente estamos ensaiando uma cena. Do mesmo modo, não acreditamos na necessidade de aquecimento como regra. Há dias em que todos estão tão carregados de atravessamentos que é preciso um esfriamento. Ou então há dias em que apenas estarmos ali juntos é o suficiente, ainda que esse "estar juntos" sempre gere acontecimentos, mínimos que sejam, como olhar a janela de vidro em uma tarde de chuva ${ }^{88}$. Nos exercícios e jogos, as regras e os enunciados incorporam o desvio. De acordo com Sanchez:
A prática artística participa na profanação alterando momentaneamente as condições de enunciação, tornando visível o escondido, cometendo atos de sabotagem seletivos, reorganizando as peças até o absurdo, detendo temporalmente o funcionamento do mecanismo, invertendo a direção das linhas ou as voltas, produzindo maquetes efêmeras entendidas como objetos de observação ou como experimentos de subjetivação alternativos ${ }^{89}$.

Muitas vezes essas profanações ou sabotagens acontecem por um entendimento diferente, ou mesmo vontade de fazer diferente do que foi enunciado. No caso do procedimento descrito, antes de criarmos a simultaneidade de narrativas, cada participante foi convidado a contar um sonho aos demais, a partir da proposta de que era um sonho que ocorre durante o sono. Valéria foi contar o seu. Ela queria falar e gostava de fazer as cenas, era uma das participantes mais antigas e assíduas. Quando ela fala é com uma intensidade hesitante, como se tivessem forças enormes colidindo dentro dela, e essas forças às vezes parecem tão intensas que ela fala com um fiapo de voz.

\footnotetext{
${ }^{88}$ Estudo de caso descrito no segundo capítulo.

89 SÁNCHEZ, José A. A pesquisa artística e a arte dos dispositivos. Questão de Crítica, v. VIII, n. 65, ago. 2015. Disponível em: <http://www.questaodecritica.com.br/2015/08/a-pesquisaartistica-e-a-arte-dos-dispositivos/>. Acesso em: 11 fev. 2020.
} 
Todos nós passamos, em um momento ou outro, por esse tipo de intensidade, mas existem pessoas que ficam mais tempo ali, ou que habitam essa intensidade com menos margem de manobra. Assim como outras pessoas do grupo - e também em nossos momentos abissais - parece que as vezes é por um triz que conseguimos fazer algo ${ }^{90}$.

Para que ela pudesse contar o sonho, o performer Eduardo Lettiere a conduz para a área cênica, sai, solta a mão dela e se afasta. Valéria senta no chão, ajoelhada sobre os pés, fala de modo pausado e fica um pouco corada ao fazer uma revelação, que demora certo tempo para acontecer ${ }^{91}$ :

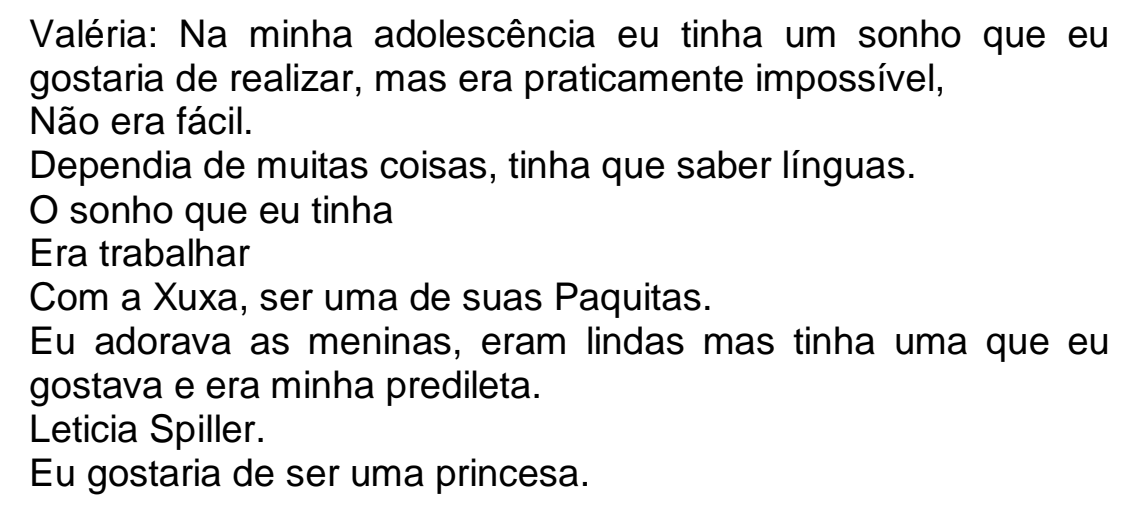

Depois da narrativa, Eduardo pega de novo na mão de Valéria e vão embora. Apesar da indicação inicial ser a de um sonho de quando se está dormindo, Valéria trouxe esse desejo antigo (sonho como sinônimo de desejo), e aqui resolvemos não somente manter a sua narrativa, mas abrir uma clareira expressiva que pudesse conter e fazer caber a cena, achando uma forma para isso acontecer.

Em seu relato havia o contraste entre a profundidade da sua revelação e a superficialidade do universo televisivo do tema. Era uma narrativa delicada e vulnerável, e por isso mesmo tocante; não poderia entrar no meio de uma polifonia de vozes, de uma paisagem sonora entrecortada de trechos dos sonhos do resto do elenco. A narração simultânea dos sonhos era uma das últimas cenas do espetáculo. Deixamos a cena de Valéria acontecer em outro momento, separada e protegida. Nesse caso, observamos uma das estratégias

\footnotetext{
${ }^{90}$ De acordo com Peter Pal Pélbart, "é por um triz que nos apresentamos, é por um triz que não morremos, mas nada disso deve ser ocultado, é um ingrediente que faz parte e faz parte dessa estética, ou dessa ética" (PELBART, O teatro da loucura. Poliética, São Paulo, v. 1, n. 1, p.119-129, 2013. Disponível em: <https://revistas.pucsp.br/PoliEtica/article/view/15206>. Acesso em: 2. abr. 2020.

${ }^{91}$ A divisão das linhas na citação é uma tentativa de reproduzir as pausas da atriz.
} 
para projetar dimensão estética aos corpos singulares, que pode ser: fazer uma separação da cena, ou abertura dessa clareira. Ao circunscrever a cena, damos a ela outro lugar.

E depois, no encadeamento dramatúrgico do espetáculo, o sonho da Paquita funciona como uma espécie de teaser, um pequeno preâmbulo do que virá, como uma folha que rodopia antes da tempestade.

Outra situação de improviso, acontecida nos encontros da ONG Ser em Cena durante a criação do espetáculo Do outro lado do oceano, traz um exemplo diferente de como legitimar uma singularidade a partir de um desvio do enunciado proposto.

O enunciado: uma pessoa entra e se posiciona em uma imagem parada, verbalizando "eu sou X". Uma segunda pessoa entra e propõe outra imagem que se relaciona com a primeira, faz sua posição e anuncia "eu sou Y". A terceira faz a mesma coisa. Então a primeira sai e entra uma nova, de modo que sempre há um quadro vivo com três pessoas em cena e a mais antiga sai do quadro. Eventualmente, em alguns desses quadros, podemos indicar para as pessoas darem movimento à cena. É um exercício simples que pode gerar materiais interessantes.

Hugo, um senhor elegante de uns 60 anos que sempre vinha aos encontros de terno e camisa social, entra em cena andando e faz uma espécie de mímica contida do voar com os braços. Pára, olha para a plateia, diz: "eu sou um urubu", e fica parado nessa posição. Depois entra Ane, como que se esgueirando, posiciona-se em um local onde o "urubu" não a vê, aponta uma arma imaginária e diz: "eu sou uma matadora de urubu". Também fica congelada com a arma em punho.

A partir desse diálogo, propusemos uma sequência de matadores de matadores que no final se matam, em câmera lenta e de maneira melodramática, e o urubu sai ileso. Ou seja, depois de Ane, entram mais pessoas, uma de cada vez, se posicionam com uma "arma" atrás do último matador e falam: "eu sou o matador da matadora de urubu", e assim por diante.

Alguns demoram para falar, o que confere suspense à cena, suspense que cabe nessa atmosfera kitsch de quase matança geral. Mais para o final, Jansen entra, coloca-se em sua posição, olha para o público e diz: "urubu urubu urubu urubu urubu urubu". Isso criou uma surpresa. 
O modo de Jansen fazer a cena produz um pequeno abalo que desperta a percepção de quem vê. Além disso, a própria cena traz essas descontinuidades, pois, mesmo com outras pessoas falando o texto "certo", a partir da segunda pessoa, o público sabe o que vai acontecer (pelo menos por um tempo), e ficamos olhando como cada uma e cada um vai fazer a sua entrada e a sua apresentação.

Como diz Sergio Zlotnic,

Nesse jogo, algo notável se dá: os atores deixam de ser afásicos - sem deixar de sê-lo! As afasias se tornam coadjuvantes. Pois a sua língua peculiar-desviante - pousa noutro léxico: o da cena teatral. Ali, suas singularidades e equívocos ganham lugar e legitimidade. Ali, a língua do afásico flutua com toda liberdade ${ }^{92}$.

Nos dois casos, tivemos desvios do dispositivo proposto. Em ambos, as vulnerabilidades e particularidades instauraram uma potência estética relacionada a um modo de representar que partiu de um entendimento próprio de um enunciado (contar o sonho, ser matador de urubu). Para Julia Guimarães Mendes,

[...] o "erro" pode tanto projetar uma dimensão de autenticidade sobre essas presenças como também expressar um tipo de vulnerabilidade plena de significados para o contexto atual, que pode remeter à simbologia de uma representação em crise permanente $^{93}$.

Aqui, assim como nos outros coletivos abordados neste estudo, não se trata de colocar as pessoas como elas são em cena. Não se garante essa potência só porque se têm em cena grupos vulneráveis, desviantes ou de outros tipos de heterogeneidade. Para se abrir essa clareira expressiva é preciso algo além de um emolduramento do que seria excêntrico: é importante que possamos construir possibilidades ficcionais para essas singularidades, e aprimorar o repertório cênico - existencial de cada um e cada uma.

Procuramos modos de fazer com que cada pessoa possa ampliar seu repertório criativo, desenvolver o que pode ser desenvolvido dentro de suas

\footnotetext{
${ }^{92}$ ZLOTNIC, Sergio. Do outro lado do oceano [on-line]. SP Escola de Teatro, s.d. Disponível em: <http://www.spescoladeteatro.org.br/noticias/ver.php?id=5542>. Acesso em: 7 jun. 2019.

${ }^{93}$ MENDES, Julia Guimarães. Teatros do real, teatros do outro: os atores do cotidiano em cena contemporânea. São Paulo, 2017. Tese (Doutorado em Teoria e Prática do Teatro) Escola de Comunicações e Artes, Universidade de São Paulo. p.51.
} 
próprias características. E ao mesmo tempo, realizar isso em um grupo em que cada um tenha suas possibilidades, seus limites e seus atravessamentos. Essa heterogeneidade que, de certa forma, acontece em qualquer ajuntamento coletivo, em alguns desses casos (como em coletivos que envolvem pacientes de hospitais psiquiátricos ou pessoas com afasia, por exemplo), torna-se mais evidente e suscita diferentes formas de abordagem. Dentre essas formas de abordagens, alguns dispositivos e conceitos do teatro e da performance são potentes para se criar outros de si mesmo: no lugar de personagens, criamos figuras, construímos personas, inventamos molduras ficcionais.

Esses conceitos têm suas diferenças e seus atravessamentos, e vou me estender um pouco sobre eles a partir de algumas experiências práticas, de modo a oferecer pistas de dispositivos de criação, mais do que de traçar definições ou delimitações teóricas.

\section{Fundo e superfície}

As figuras têm características ou funções que criam uma moldura e um reconhecimento imediatos, contextualizando os movimentos e gestos dos performers dentro de um enquadre ficcional, como pudemos ver no caso dos matadores de urubu, ou no trecho anterior que descreve a cena da cantora fantasma. Uma cena com marinheiros ou outra com criaturas marinhas que faziam parte do espetáculo Do outro lado do oceano nos ajudarão a entender diferentes possibilidades de criação de figuras e de molduras ficcionais.

Em um dos encontros da Ser em Cena, pedi aos participantes que fizessem um gesto ou um movimento que se relacionasse a um momento significativo da vida deles, e nós não precisaríamos reconhecer o que representava ou significava. Entre o conjunto de gestos produzidos, alguns tendiam para uma tentativa de aproximação realista, outros mais abstratos,

mas de modo geral me surpreendeu a densidade e o grau de implicação deles com a proposta, o que resultou em uma anotação no inventório de que aquilo poderia ser transformado em uma cena.

Nesse dia só vieram algumas pessoas da turma, todos homens e, em sua maioria, com mais de 50 anos, o que conferia certa atmosfera à cena.

Mantivemos o elenco original e repetimos essa improvisação algumas vezes, tentando fixar não os gestos, mas o trilho físico-emocional que instaurava a atmosfera correta (de acordo com o que foi criado da primeira 
vez). Achar a música adequada para essa atmosfera, ajudou muito, mas ao mesmo tempo foi importante que, nas primeiras vezes, eles fizessem sem a música, para não virar (no caso dessa cena, não é uma regra) uma muleta emocional que conduzisse os movimentos.

Fotografia 29 - Cena: Os marinheiros se lembram da terra. Do outro lado do oceano - Ser em Cena, 2016

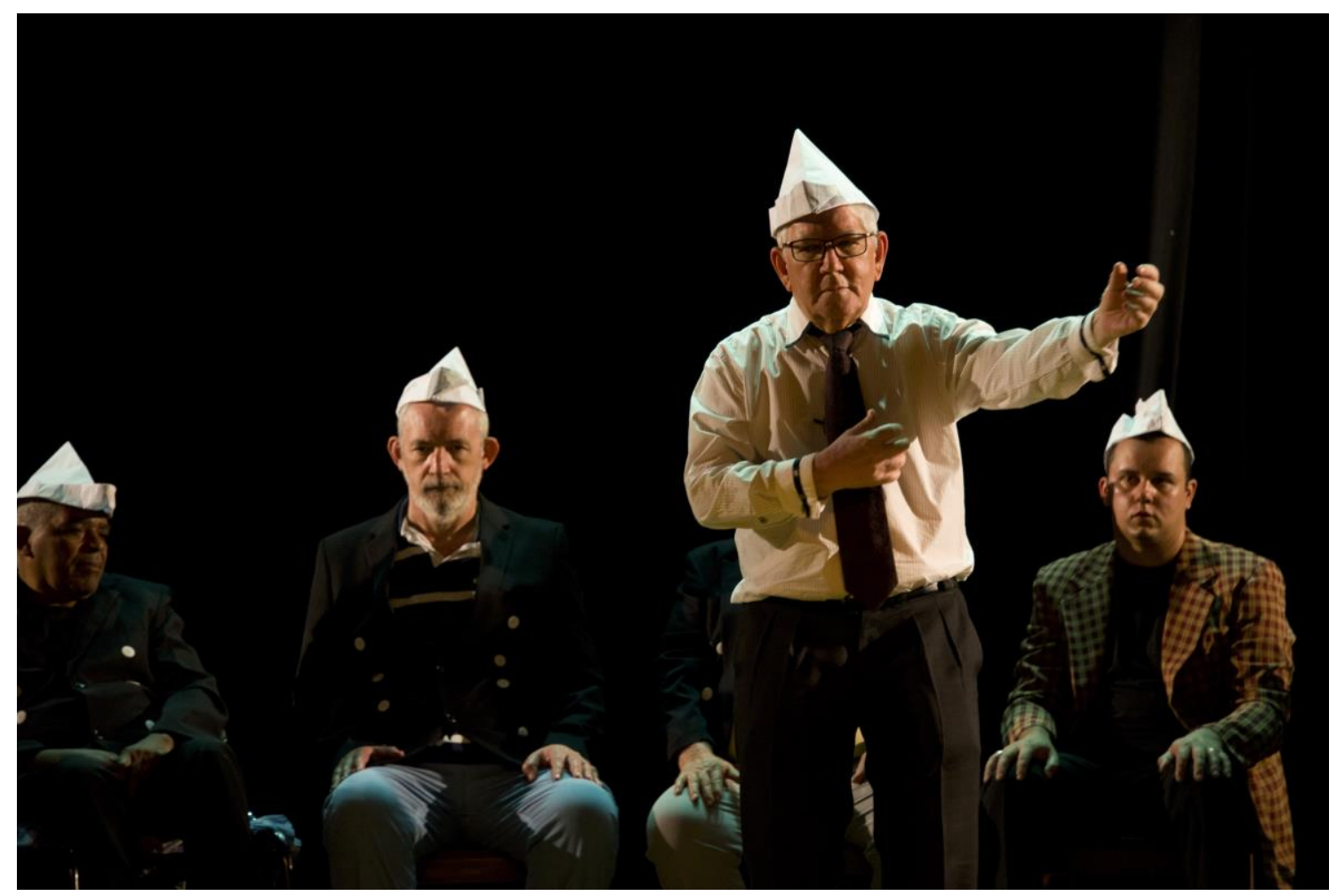

Roberto Souza, Ronaldo Serino, João Correa e Michael Aguiar. Foto: Karina Bacci.

No espetáculo, a cena aconteceu com eles sentados em semicírculo aberto $^{94}$, com chapéus de papel em formato de barco ${ }^{95}$. Posicionados dessa maneira, um de cada vez fazia os gestos ao som do grupo Les Musiciens de Lviv, uma banda masculina ucraniana ${ }^{96}$. O último (um senhor que tem um corpo extremamente flexível e sempre executa movimentos de dança com muita desenvoltura, especialmente danças de salão) saía dançando uma valsa com um par imaginário.

94 Optamos por eles sentados, pois essa turma tem, em sua maioria, pessoas mais velhas, alguns cadeirantes e com alguma dificuldade de locomoção.

${ }_{95}$ Contribuição da artista Marina Reis, que colaborou no figurino.

${ }^{96}$ Link da música utilizada disponível em: <https://www.youtube.com/watch?v=dJQWxdd16ys>. Acesso em: 12 abr. 2020. (Por favor, ouvir com fone de ouvido para não perder os graves do contrabaixo.) 
Nesse caso, eles não mudaram nada do que haviam feito, mas criamos uma moldura ficcional externa que deu uma nova camada à cena, ao contextualizar seus movimentos. Logo no início da cena, uma placa anunciava o título: Marinheiros se lembram da terra.

Com outra turma, durante um procedimento comum, de se pedir aos participantes que se movimentem de um modo diferente, prestando atenção às sensações, me chamou à atenção a qualidade de movimento do Massao. Ele estava com 80 anos e um pouco de dificuldade para andar, mas durante 0 exercício movia o corpo com muita graça e delicadeza, com uma imprevisibilidade de movimentos que eram como um respiro, e também com expressões que ora eram engraçadas, ora triangulavam com quem estava vendo, ora eram poéticas e lembravam a dança butoh. Novamente, é difícil explicar a potência de um acontecimento em palavras, mas alguma coisa em sua dança me deixou tocada.

Fotografia 30 - Cena: Comitê de observação das criaturas marinhas. Do outro lado do oceano - Ser em Cena, 2016

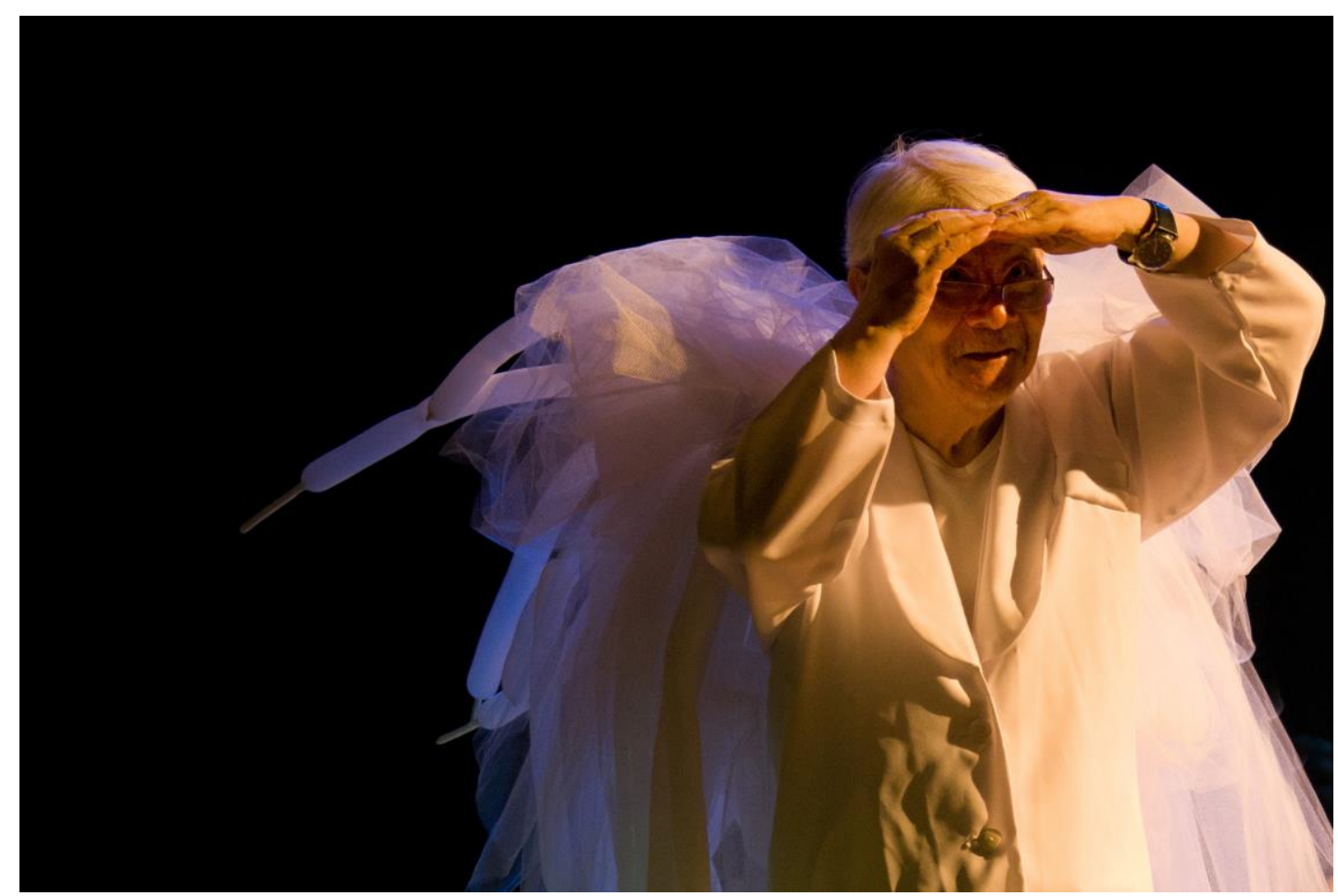

Massao Ukon. Foto: Karina Bacci.

Nos encontros seguintes, repeti o exercício coletivamente - e observava se ele mantinha a luminosidade da primeira vez, o que sempre acontecia, mesmo com uma certa variação dos movimentos. Não havia muita 
possibilidade de indicações ou trocas verbais, pois ele falava e entendia somente japonês ${ }^{97}$. Quem nos salvava um pouco era Antônia, sua esposa, que sabia algumas palavras básicas, e Evelyn, assistente de atividades na ONG, que também conhecia um pouco da língua.

Entre meus gestos e expressões, e o vocabulário de Evelyn e Antônia, continuamos, e um dia sugeri que todos se mexessem como se fossem criaturas marinhas. Experimentei outra música, e Massao fez uma dança mais bela ainda. Não sei o quanto de "criaturas marinhas" ele entendeu, mas eu visualizei ali um "papel" para ele.

Criamos uma cena chamada Comitê de observação das criaturas marinhas. Após o título narrado em off, entrava um grupo de pessoas, e um ator anunciava ao público: "boa noite, nós somos o comitê de observação das criaturas marinhas e vamos observar agora uma espécie raríssima e belíssima" ${ }^{\text {" }}$.

Então Massao entrava e fazia a sua dança. Ele interagia com as pessoas que estivessem no ambiente, que eram os atores da cena, e outras pessoas que estivessem assistindo, de modo que às vezes ficava bastante tempo de costas para a plateia, o que não era um problema no sentido de uma marcação tradicional de teatro. Mas havia dias em que ele ficava assim quase a cena toda e seria bom que sua dança acontecesse em diferentes direções. Propus que alguém atravessasse a frente da área cênica bem devagar, como um mergulhador, o que funcionou, pois ele começou a interagir com a pessoa. Depois fizemos um escafandro, e no dia em que ficou pronto, experimentamos uma epifania.

Suspeito que o escafandro funcionou melhor do que mil palavras que eu tenha dito sobre criaturas marinhas, fundo do mar ou qualidade de movimento ${ }^{99}$. No ano seguinte, a sua saúde estava mais comprometida, e duas

\footnotetext{
${ }^{97}$ Após o AVC, ele passou a falar somente em sua língua materna, o japonês, mas continuava tocando sax, atividade que exerceu durante mais de trinta anos como músico de uma banda de jazz tradicional de São Paulo.

${ }_{98}$ Também aqui escolhemos um ator que tem uma fala peculiar, um pouco lenta, o que combinava com a função de líder, ou porta-voz, do Comitê de observação das criaturas marinhas.

${ }^{99}$ Ele sabia estar participando da montagem de uma peça de teatro e gostava muito dessa atividade - Antônia relatava que, no dia do encontro, ele se trocava e ficava pronto sentado no sofá três horas antes de buscá-los - mas não sei o quanto percebia das cenas ou do espetáculo como um todo.
} 
atrizes participaram da cena ${ }^{100}$, formando como que um triângulo em que ele era o vértice. E elas faziam sombra do seu movimento com alterações de intensidade ou ritmo, o que fazia com que os três formassem uma espécie de cardume, ou que elas fossem nadadeiras dessa criatura.

Fotografia 31 - Cena: Comitê de observação das criaturas marinhas. Do outro lado do oceano - Ser em Cena, 2016

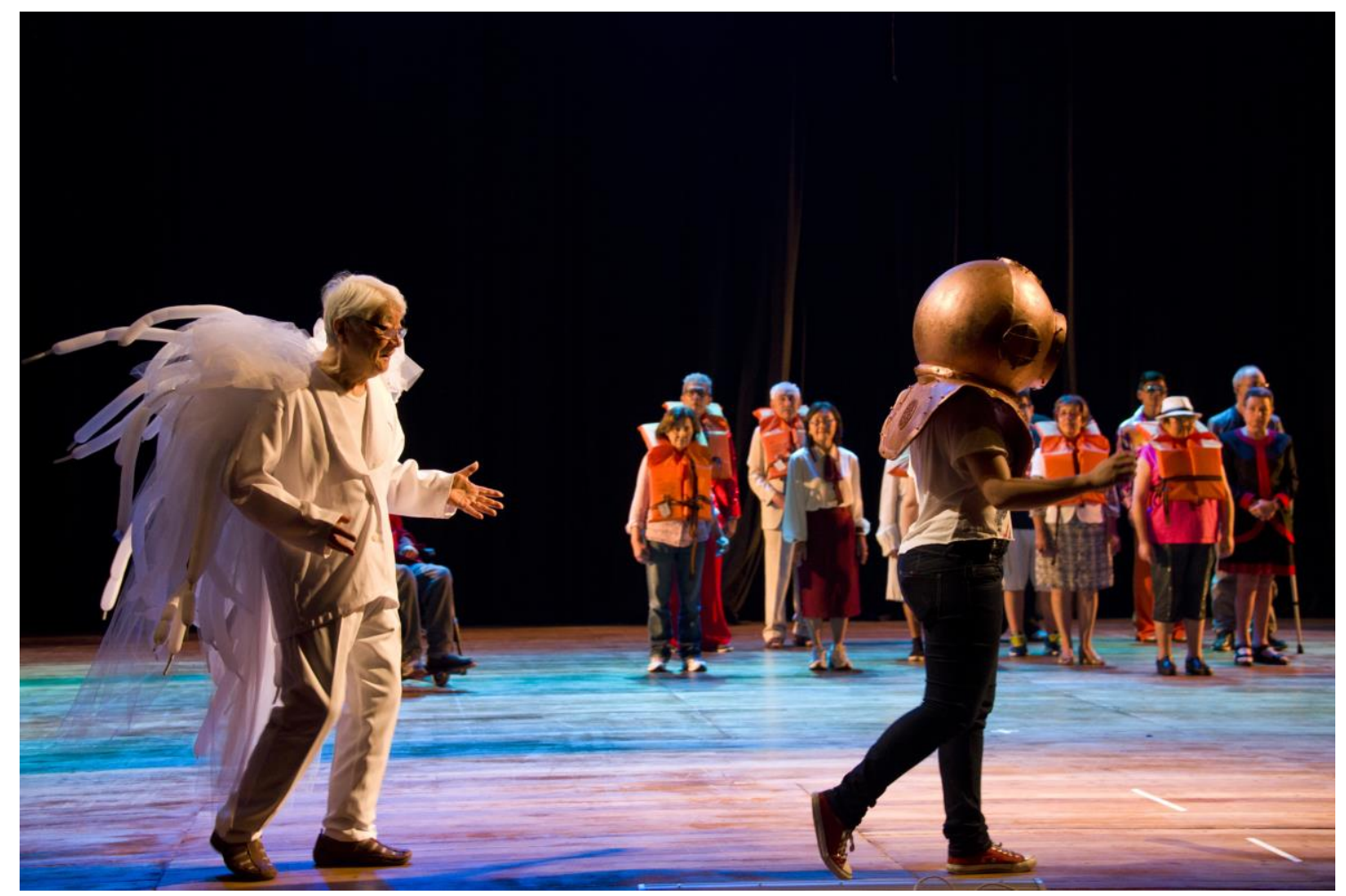

Massao Ukon e elenco da ser em cena. Foto: Karina Bacci.

O formato pode ser aberto. Nunca ficou claro para nós se elas eram partes dele ou seres separados, mas isso não quer dizer que poderia ser feito de qualquer jeito: ensaiamos bastante para conseguir a qualidade de sombras distorcidas dos movimentos delas em relação aos dele. A inserção delas na cena aconteceu porque, como ele vinha sofrendo algumas fraquezas momentâneas, elas o amparariam caso isso ocorresse, o que chegou a acontecer uma vez no ensaio e nos assustou.

Considerei suprimir a cena, mas Massao insistiu que gostaria de continuar participando. Dessa vez conversamos com a ajuda da Yoshiko, que havia se juntado ao grupo e falava japonês fluente. Avaliamos a situação com a

\footnotetext{
100 A ONG contrata assistentes para ajudar na montagem no segundo semestre, e essas assistentes acabam participando do elenco.
} 
equipe clínica e decidimos que as criaturas marinhas continuariam. De qualquer modo, foi um pacto acordado entre nós (Antônia, equipe da ONG e Massao), que envolvia um certo risco, mas decidimos sustentar o desejo do Massao (e nosso) e entendemos que era seguro e possível esse arranjo. As assistentes Dandara Lima e Amanda Muraca se desdobraram com sensibilidade nessa função múltipla de criar linguagem e rede de segurança ao mesmo tempo.

Esses dois casos, dos marinheiros e das criaturas marinhas, apontam diferentes possibilidades na criação de figuras, ou funções, e também evidenciam os ajustes mútuos para que algo aconteça, as negociações e os elementos mais imponderáveis que participam da criação de uma cena em nossos coletivos.

\section{Outros modos de ser}

Guardando semelhanças com as figuras e funções, mas com algumas outras particularidades, voltamos ao caso de Valéria.

Além de sua narrativa da Paquita, que acontecia quase no final do espetáculo, Valéria participava de duas cenas que criavam uma sustentação ficcional para ela, ou uma coerência própria dentro da peça.

$\mathrm{Na}$ quinta cena do espetáculo, um ator anunciava com pompa: "senhoras e senhores, Mademoiselle Valerie!". Valéria aparecia e era conduzida pelo "cocheiro" (outra figura) até sentar na base de uma escadinha de três degraus. O cocheiro se posicionava no degrau mais alto e "conduzia" outra atriz, que fazia os movimentos de um cavalo. Sem deslocamento pelo espaço, a cena sugeria um percurso de carruagem, no final do qual o cocheiro abria a porta e Mademoiselle Valerie saía.

Na cena seguinte, Valéria contracenava com outra atriz, Erika Inforsato, que desenvolvia um jogo gestual de arrumá-la, sinalizar para ela levantar e mudar o banco de lugar. Quando Valéria ia sentar, Erika deixava uma dúvida se iria retirar o banco novamente. Esse jogo conferia à cena um caráter de instabilidade conduzido pelas atrizes, que ficavam entre uma relação de poder, subserviência e insujeição.

As interpretações, assim como os figurinos das atrizes, não se fechavam em personagens de aristocrata, ou de camareira, mas mantinham pequenos 
indícios dessas funções ou posições: pérolas, grampos que uma colocava na outra etc. Assim, a narrativa da Paquita e as cenas que a precediam, evocavam alguém com traços aristocráticos, que não é mais somente a performer, mas que também não se completa como personagem com uma psicologia própria. A criação dessas outras de si de Valéria e de Erika podem ser pensadas a partir do conceito de persona.

Tive contato a primeira vez com essa palavra, quando fomos dirigidos por Renato Cohen em 1998 em nossa montagem final da graduação ${ }^{101}$ e investigamos na prática alguns conceitos descritos em seus livros:

Uma persona é uma galeria de personagens (por exemplo, velho chamado $\mathrm{x}$ com característica y). $\mathrm{O}$ trabalho do performer é de "levantar" sua persona. Isso geralmente se dá pela forma, de fora para dentro (a partir da postura, da energia, da roupagem desta persona). $\mathrm{O}$ fato de se trabalhar a partir do exterior faz com que, em geral, as personas não sejam realistas, muito embora tenham uma energia própria, que guardam uma verossimilhança com o modelo original ${ }^{102}$.

Além das práticas com Renato, alguns workshops e cursos que fiz com Cristiane Paoli-Quito também foram valiosos para compor e acessar esses outros de si, como visto no segundo capitulo. Tanto com Cohen como com Quito, cada participante partia de diferentes equilíbrios e dinâmicas corporais e deslocamentos pelo espaço, ou então de partes do corpo que conduzem os movimentos, para se criar um corpo diferente do seu, que se move e se relaciona nessa outra lógica sem, no entanto, fechar seu significado a uma ideia de personagem ou função.

Também acrescento as experiências que tive com o diretor e dramaturgo Maurício Paroni, com quem trabalhei como atriz em alguns espetáculos. Maurício utilizava frequentemente as imagens do pintor Egon Schiele para nos inspirar a compor personagens, não como tema (reproduzir as pessoas retratadas) mas pelo modo com que fazia seus retratos. Nas suas pinturas, parte das figuras está esboçada, feita a mão em um rabisco a lápis, que de repente se transforma em uma pintura mais "bem-acabada", com cores e texturas. Essa imagem que ele trazia nos liberava de um vício inconsciente e

\footnotetext{
${ }^{101}$ Ana Goldenstein Carvalhaes, que foi aluna e trabalhou com Renato Cohen, investiga esse tema em sua dissertação de mestrado, Persona performática: alteridade e experiência na obra de Renato Cohen (São Paulo: Perspectiva, 2012).

${ }^{102}$ COHEN, 1989, p.107-8.
} 
muito comum nas atrizes e atores, de se interpretar que se está interpretando: interpretar o que se imagina ser uma boa interpretação, o que geralmente produz uma qualidade impostada e solene. O exercício proposto por Maurício resultava em uma vitalidade e despretensão na interpretação e na criação de personagens.

Mais do que tentar estabelecer o que essas diferentes aproximações têm em comum - o que pode ser entendido como uma certa irreverência ou liberdade de composição, que não procura entender a psicologia de um personagem, mas parte de elementos externos e geralmente corporais -, começamos a perceber a diversidade de possibilidades de criações desses outros de si.

Fotografia 32 - Curso de performance do Igual Diferente - MAM, 2018

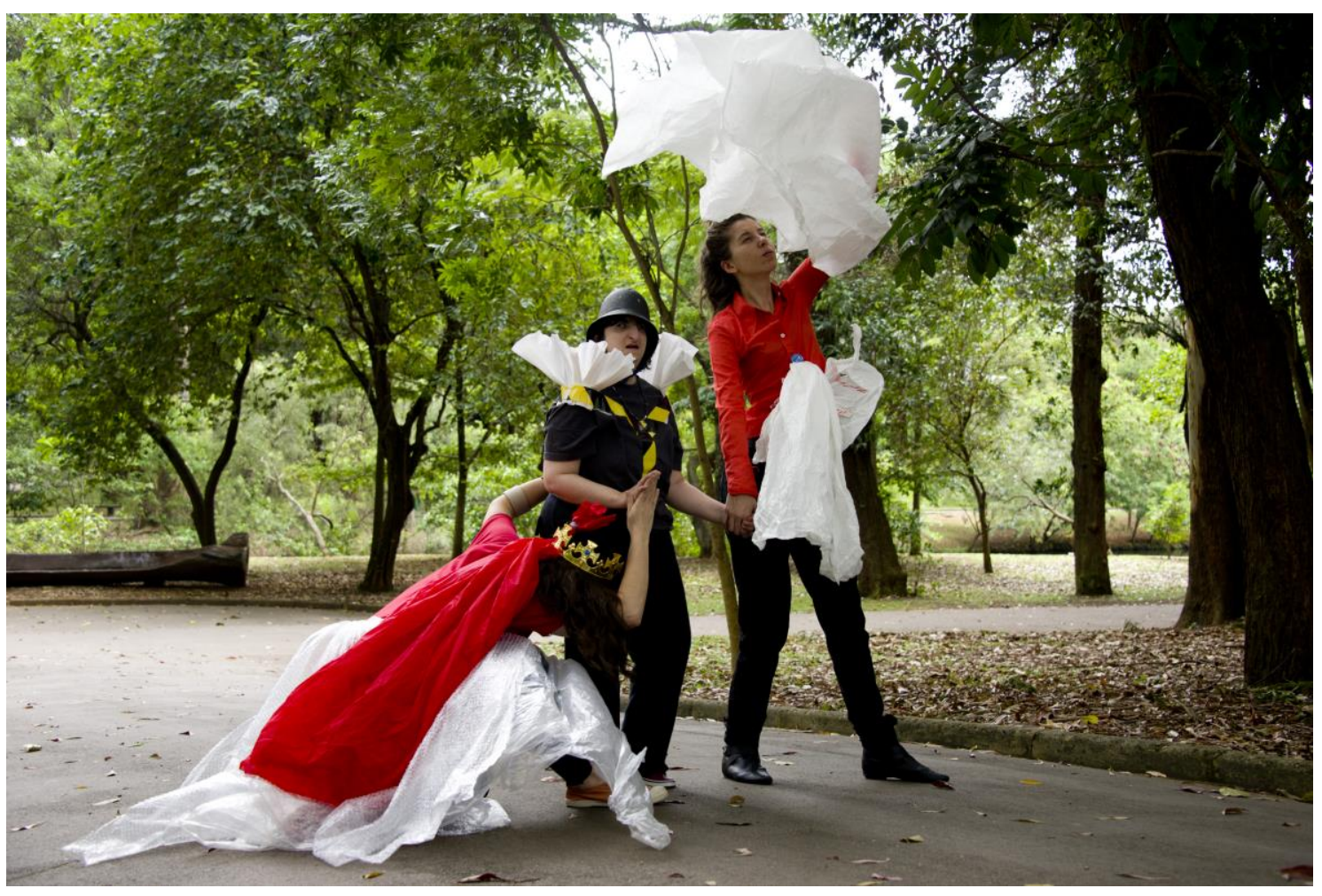

Fernanda Zardo, Ana Cardelli e Barbara Jimenez. Foto: Karina Bacci.

A persona não é mais a pessoa, mas também não é um personagem. Guarda traços de um e de outro, habitando uma zona híbrida, o que de certa forma protege o performer, pois ele não está ali sendo simplesmente ele 
mesmo, e também não precisa estar submetido à ilusão de coerência exigida de uma personagem ${ }^{103}$.

Estamos falando de um outro de si mesmo que transborda da cena. Em nossos coletivos, para algumas pessoas, esses transbordamentos acontecem naturalmente, de modo que, por um lado, esse dispositivo "cai como uma luva" para certas pessoas; por outro, há que se ter um cuidado no fechamento dos exercícios. Em um dos coletivos, após um exercício de relaxamento em que as pessoas deitaram de olhos fechados, um participante me indagou se eu observei se o seu corpo ficou no lugar durante o exercício de relaxamento. Esse mesmo participante, durante exercícios os mais simples, como fazer um gesto com as mãos, me perguntava às vezes se eu conseguia ver se ele tinha conseguido sair do personagem. É possível abrirmo-nos à reflexão a respeito de como a presença, considerada uma unidade mínima na equação cênica, também pode ser questionada - o que nos levaria a encarar o indivíduo como sendo perpassado muito mais por fluxos, atravessamentos e contágios.

Há um estudo de Philip Auslander ${ }^{104}$ que, por meio da filosofia desconstrutivista, questiona as diferentes teorias teatrais que abordam 0 conceito de presença.

Para a presente dissertação, mais do que embarcar em uma tarefa de tentar definir exaustivamente o que seria presença, tarefa esta que foge do escopo deste trabalho, é mais útil pensar como, em nossas práticas, experimentamos a maneira pela qual a ideia de persona pode se afinar com diferentes possibilidades ou densidades dessa presença, dentro e fora da cena:

No teatro, a presença é a matriz do poder; o teatro de resistência pós-moderno deve, portanto, expor o conluio da presença com autoridade e resistir a esse conluio, recusandose a estabelecer-se como o Outro carismático ${ }^{105}$.

\footnotetext{
103 Jean-Pierre Sarrazac já antevê essas questões a respeito da coerência ou unidade do personagem em seu livro Léxico do drama moderno e contemporâneo (São Paulo: Cosac Naify, 2012, p.137). Em seu verbete sobre crise do personagem, diz que "muito antes do teatro do absurdo, Strindberg e Pirandello haviam iluminado as contradições, incoerências e pontos de vista múltiplos e cambiantes de uma 'alma' supostamente única", ou então na pergunta: "As consequências dessa perda de identidade são capitais, pois se não é mais o 'eu' no palco, quem é esse 'outro'?".

104 AUSLANDER, Philip. From Acting to Performance: Essays in Modernism and Postmodernism. [S.I]: Routledge, 2002. p. 66.

${ }^{105}$ Ibidem, p.63.
} 
Quando Auslander termina esse trecho falando de uma recusa do Outro carismático, proponho um deslocamento: a questão não é recusar o Outro carismático, mas desvincular carisma de técnica ou saber específico, de modo que o carisma pode emergir de outros pressupostos, como a vulnerabilidade.

A presença pode ser vulnerável, frágil, e dessas qualidades extrair sua força, visto que pode ser a potência de um "modo de vida que ganha legitimidade dos mais diferentes modos, com outras qualidades de presença e de corpos que não os treinados para o palco" ${ }^{106}$.

Ao contrário de uma presença "forte", relacionada com produtividade, desempenho, vigor,

Um dos desafios contemporâneos na blindagem dessa cultura do atletismo, do vigor, é poder desenvolver/sustentar uma vulnerabilidade. É preciso ter a força de sustentar uma fraqueza, para não ter a fraqueza de sustentar apenas uma força ${ }^{107}$.

Essa discussão da presença pode ser um operador de leitura para pensarmos o conceito de persona. Para Renato Cohen, a persona é criada a partir das idiossincrasias, das particularidades da pessoa, e traz uma carga de fugacidade e de entrelaçamento entre arte e vida cujas fronteiras ficam borradas $^{108}$. Ao trazer à tona as diferentes qualidades que uma presença pode ter, a ideia de persona se materializa em suas inexatidões, assimetrias, em seus estados fluidos, inacabados e múltiplos ${ }^{109}$.

\section{Uma cor indefinível}

Iza Cremonini foi atriz da Cia. Ueinzz desde sua fundação. A sua densidade existencial transbordava para a cena e para fora dela, e qualquer coisa que ela fizesse capturava a nossa alma. Havia nela algo de Klaus Kinski, e também de uma qualidade pré-verbal e mágica, anterior às palavras,

\footnotetext{
${ }^{106}$ FABIÃO, Eleonora. Poéticas e politicas da cena contemporânea. Sala Preta, n. 8, p. 245. DOI: https://doi.org/10.11606/issn.2238-3867.v8i0p235-246.

${ }_{107}$ PELBART, Palestra proferida no Centro de Referência da Dança, 21 de junho de 2018.

${ }^{108}$ COHEN, Work in progress na cena contemporânea. São Paulo: Perspectiva, 1998.

109 Com relação a essa discussão e à ideia de personagem, Jacó Guinsburg me relatou em uma conversa que a "performance nada mais é do que o teatro com pretensões hipernaturalistas". Mais do que tentar escolher um "lado" entre essa afirmação e a de Richard Schechner, para o qual o teatro faz parte da performance, podemos imaginar que o que diferencia persona de personagem são gradações diferentes de formalização, ficcionalização de um personagem, e de abertura a esse entrelaçamento entre arte e vida.
} 
qualidade que Antonin Artaud buscava e tantos artistas perseguem. Era às vezes amorosa, e outras, muito difícil.

Iza convivia com abismos, e construía figuras, ou personas, que eram, assim como sua personalidade, enigmáticas e intensas. Durante a criação do espetáculo Finnegans Ueinzz, no procedimento descrito dos sonhos, ela nos trouxe um relato que, no lugar de entrar na travessia simultânea dos sonhos coletivos, também (assim como o de Valéria) entrou separadamente em outro momento.

Ela também criou uma cena que se relacionava com a narrativa onírica, com um elemento final que mencionava o teatro e personagens. Essa composição tinha um efeito surpreendente e um pouco cômico (a comicidade possível dentro da densidade de Iza), graças ao contraste entre sua afirmação de que somos personagens e sua figura polissêmica, construída com um casquete ${ }^{110}$ de pérolas, um cajado de madeira que ela segurava e uma calça jeans, formando uma colagem de tempos, estilos e lugares.

O seu terceiro texto era um monólogo que ela trouxe e que, assim como Massao, desde a primeira vez que ela nos mostrou, estava praticamente pronto. Às vezes só é preciso dar sustentação para que algo aconteça, e legitimar o improvável. O texto de Iza virou a cena final do espetáculo. Uma colagem, ou orquestração, feita de diversos tempos, lugares e vozes, palavras inventadas, outras línguas, conversas com um ente invisível, devir animal. Caleidoscópio de assuntos e intensidades que, apesar de não ter uma linha do Finnegans Wake de James Joyce, de alguma forma se aproximava, traduzia e dava corpo a esse acontecimento múltiplo e inclassificável.

A seguir os dois trechos finais de Iza (aqui também as quebras de linhas correspondem às pausas da fala):

\section{Cena 17: Parque}

Você é presa fácil. Você transparece medo, isso não é viver, não adiantam os modismos, nunca você conseguirá se livrar deles se não for forte, porque na verdade, uns ou outros, pela literatura, pela música, pelo que seja, não se foge, de sermos todos personagens de Nelson Rodrigues.

Cena 31: Iza

\footnotetext{
${ }^{110}$ Tipo de chapéu feminino elegante dos anos 1920.
} 
Três luas, três luas esperei,

Para estar no meu local,

Que é meu de direito,

Meu e da criatura aprendiz Tosco,

Três luas, onde acontecimentos terríveis aconteceram.

Levaram-na! Levaram-na de nós!

Sem explicação, se houvesse um motivo,

Não houve um motivo para nós,

Para nós criaturas que convivemos com ela,

Criatura inteligente, garbosa,

Bonita, impaciente, impertinente,

Com ela trocamos muita coisa, mas levaram-na...

E agora, quando lembro disso,

E é sempre aqui no meu local, no meu sótão,

Onde tenho o direito de ficar isolada,

Uma criatura isolada.

Meus dedos no início ficam verdes,

Sobe a coloração verde até a cintura,

Ela vai se tornando mais forte,

Acima da cintura do lado esquerdo,

Onde tenho quase um rotor que não para de funcionar,

Aí fico rubra, uma criatura rubra.

Em certas luas, eu me arrisquei a falar, in certain moons,

Apesar do exemplo, do conselho da natureza, minha única amiga: - Não fale. Falei.

Eles cortaram o prolongamento do meu corpo,

Deceparam o meu rabo, que era lindo,

Uma pelagem delicada, uma cor indefinível,

Uma musculatura como a dos dinossauros jovens,

Era lindo, mas... tenho projetos, o quê Tosco?

Ah, sim, ubutu ubutu, ohróroró.

Eu sou terrível, vou lhe contar,

Eu ponho tudo pra baralhar,

Não sei mais o que cantar,

Porque não sei a letra, não me interessa,

Oh sim, letra maravilhosa que vocês nos deram,

Muito, vinte e quatro horas ela é o nosso hino,

Ah isso, veio cumprimentar? Ohró, Ohró.

Maldito! Execrável és!

És um deles, és uno,

São vários os deuses, mas ele é uno,

Travestido, cabelos, corpo, linguagem, vestimentas,

Adaptações mil, mas ele é uno,

E é com ele que eu vou brigar.

Estou... tosco, outra vez? Ah, sim, que eles vão,

Procurem um líder,

Que aqui eles vão pela floresta

Em busca da madeira que precisam.

Estou a tempos, pensando em fios e cordas,

Em uma maneira de caçá-los a todos,

Porque eles são invisíveis, por isso que nos vencem,

Por que somos corpóreos, criaturas corpóreas,

Eu os caçarei a todos, todos,

Vou ter essa possibilidade, eu sei o momento, 
Os transformarei em pó, de pó em óleo,

Esse óleo será guardado em crateras no fundo mar,

Em lugar inacessível, onde só eu vou, só eu conheço,

Depois esse óleo será pincelado nas escarpas,

Nas pedras, ficará estratificado,

Desaparecerá, eles desaparecerão, os deuses,

Obsoletos, atualmente,

Mas a natureza pode mudar de opinião,

Daqui anos,

Pode achar também que a obra dela está obsoleta,

Então fará uma revolução de terra e mar,

Onde as escarpas se baterão, virarão migalhas,

A terra se misturará, não restará nada,

Nessa calmaria de centenas, milhares,

Não se sabe quanto tempo,

Surgirão as moléculas, que se chamarão outras coisas,

Dali, surgirão outras criaturas?

Pergunto, valerá o que está sendo feito hoje?

Só saberemos depois...

Esses outros de si, sejam personas, figuras, ou quems, surgem e tomam forma de acordo com os recursos cênico-existenciais do performer, e das características do processo e do espetáculo que estamos criando. Podem aparecer de uma vez, ou serem criadas aos poucos.

De modo geral, podem ter uma moldura ficcional mais direcionada à ideia de figuras ou personagens, mais reconhecíveis (a cantora emoldurada, as criaturas marinhas, o cocheiro, a vidente) ou sustentar uma criação de personas mais indeterminada, aberta a diferentes possibilidades de leituras e que escapam de categorizações. Mas em ambos os casos, nesses momentos, as pessoas desabitam sua condição patologizada de doentes, loucos ou desviantes e se tornam artistas criadores dessas outras formas de potência estética, que são instauradas justamente por assumir e legitimar outros modos de existência.

Ao criarem outros de si, também se produzem como criadores.

Para Jean Oury, "estar o mais próximo não é tocar: a maior proximidade é assumir o longínquo do outro" ${ }^{111}$. Imagino o quanto, na proximidade dessas criações, observando longínquos dos outros, os nossos territórios também não se ampliam.

A criação desses outros convoca artistas e público para lugares desconhecidos: artistas, que dão nascimento e corpo às suas personas; e

${ }^{111}$ OURY, Jean. Utopie, atopie et eutopie. Chimère, n. 28, 1996, p.75. 
público, que é imerso em um território no qual os mapas de acompanhar as peripécias de um personagem não servem.

No caso de Valéria e Jansen, partimos de algo que é culturalmente entendido como um limite, ou desvio, que pode ser por exemplo um limite de fala, ou de compreensão da proposta. Nós damos unidade e gramática para esse limite, mas preservando um componente de indeterminação, sem fechar um significado: uma gramática aberta como a da poesia, ou de uma língua inventada.

Nesses casos - assim como no caso de Iza, Massao, Erika ou os marinheiros -, não se fecha a ponto de se oferecer personagens ou drama, mas o suficiente para se ter alguma dimensão ou moldura ficcional; que pode ser fabular, conter figuras, personas, traços de personagens. Tem-se algum caminho aberto de leitura. É uma trilha, mas nunca um mapa. O público, ao entrar em contato com esses territórios cênico-existenciais, terá que inventar seus próprios mapas.

\section{Nós}

Esses mapas, ou leituras, contêm múltiplas camadas, às vezes contraditórias. Fomos convidados para apresentar Finnegans Ueinzz em um festival de teatro, Baltic Circle International Theatre Festival, na cidade de Helsinque, na Finlândia. Nessa ocasião, foi feita uma crítica sensível e elogiosa que reconheceu a singularidade artística do projeto. Reproduzimos a seguir trechos que destacam a maneira singular com que foram abordados alguns temas investigados aqui e experimentados pelo grupo. E também para observar como, de dentro dessa sensibilidade, pode sobrar sempre uma busca por sentido ou amarração.

No início a expressão facial dos atores está virada por dentro, como se seus pensamentos estivessem parcialmente náufragos, travados, presos. Contudo, sua presença não está afinada de um modo aflitivo ou angustiado, mas de uma ternura notável e de um modo digno. Essa impressão faz você ficar mais atento: você vê expressões que não querem expressar algo predeterminado, você vê rostos que não querem ser vistos de modo usual, que não querem falar em uma linguagem préfabricada. [...] Finnegans Ueinzz molda um rizoma de estilos teatrais, um organismo vivo em constante mudança, mas ensaiado, onírico, em vigília. O grupo escava uma arqueologia da mente e da linguagem ao combinar com sua própria lógica o 
singular, cenas borbulhantes e não conectáveis a citações de textos clássicos.

[...] O espaço muda de acordo com as posições e os ângulos que as pessoas estabelecem umas com as outras, o mundo é criado nessas relações, e nessas relações morre. A massa sonora funciona como uma encenação densa. A performance não deslumbra, mas foca de um modo indistinto, à medida que ao público é permitido construir suas próprias histórias, para iluminar seus próprios pontos de vista. A cena mais impressionante é a final, que amarra todos os fios soltos. Uma senhora, de face pétrea, conta que ela foi proibida de falar. Ela falou e foi punida. Mesmo assim ela falou.

A única dimensão social a ser seriamente considerada culmina na seguinte questão para o teatro atual: quem pode repensar o palco, quem pode também fazer com que esse palco seja da plateia? A performance da Companhia Teatral Ueinzz talvez não seja a única resposta, mas certamente é uma de suas sementes mais significativas. Em Finnegans Ueinzz o mundo não dorme em um tempo passado ${ }^{112}$.

O acolhimento inesperado vindo do outro lado do mundo, ressoa a afinidade com nossas investigações ao falar de "expressões que não querem expressar algo predeterminado", ou quando menciona o aspecto de ser um trabalho "ensaiado e em constante mudança". Também quando descreve poeticamente seu aspecto onírico e caleidoscópico e quando fala de uma abertura na qual "ao público é permitido construir suas próprias historias", o artigo identifica nosso esforço em pensarmos na instauração de uma gramática cênica que dá à obra uma tessitura própria.

Porém, posteriormente, a autora escreve que "a cena mais impressionante é a final que amarra todos os fios soltos". Apesar de fazer uma leitura sensível e favorável ao nosso trabalho, esse trecho traz uma questão para o nosso argumento. Se quisermos ficar com essa imagem, ela não amarra os fios, mas compartilha outro emaranhado. O monólogo de Iza tem vários elementos que fazem e desmancham sentidos móveis, que podem ou não ser relacionados ao que veio antes, mas nunca amarrados. Assim como imaginar uma linha do tempo é uma ficção, amarrar todos os fios soltos é outra. Também é ficção a coerência do personagem, ou de si mesmo.

\footnotetext{
112 SAKO, Maria. Companhia de Teatro Ueinzz mergulha no inconsciente. Helsingin Sanomat, 22 nov. 2009. Tradução John Laudenberger e Akseli Virtanen.
} 
O uso desses termos não é somente um jogo de linguagem, mas evidencia um jogo de forças a que estamos submetidos, que tencionam nossas oscilações entre fazer sentidos e desmanchar sentidos, na cena e na vida.

Os enunciados políticos ou literários [ou cênicos] fazem efeito no real. Definem modelos de palavra ou de ação, mas também regimes de intensidades sensíveis. Traçam mapas do visível, trajetórias entre o visível e o dizível, relações entre modos do ser, modos do fazer e modos do dizer. Definem variações das intensidades sensíveis, das percepções e capacidades dos corpos. Assim se apropriam dos humanos quaisquer, cavam distâncias, abrem derivações, modificam as maneiras, as velocidades e os trajetos segundo os quais aderem a uma condição, reagem a situações, reconhecem suas imagens ${ }^{113}$.

Reconfiguramos o "mapa do sensível"114 quando experimentamos cenas em que não há personagens, mas personas e figuras, nas quais não acontecem histórias, mas fluxos, repetições, silêncios, quase cenas. O espaço desse quase não é o de algo incompleto, mas uma brecha-abismo que se abre para o que é indeterminado, ingovernável, hesitante, não circunscrito a uma positividade do significado fechado, de uma história linear ou do drama de uma personagem.

Para James Joyce, uma grande parte da vida acontece "em um estado que não pode ser compreendido corretamente com o uso da linguagem desperta, da gramática correta e da trama sequencial ${ }^{115 " . ~ T e n t a m o s ~ h a b i t a r ~ e ~ c o m p a r t i l h a r ~}$ esse lugar.

Talvez os encontros com esse tipo de alteridade nos coloquem, como criadores e espectadores, em contato com características nossas que desconhecíamos (ou que não olhamos ou tentamos abafar). Criar com e observar outros modos de se mover e de estar no mundo - como pessoas com afasia, surdos, pacientes de hospitais psiquiátricos ou pessoas muito diferentes que se juntam em um mesmo grupo - pode nos apontar configurações outras para além dessas que se apresentam. O contato com corpos não domesticados, ou descontrolados, que falham e hesitam, com desejos não

\footnotetext{
${ }^{113}$ RANCIÈRE, 2009, p.59.

114 Ibidem, p.59.

${ }^{115}$ Carta de Joyce para Harriet Shwa Weaver. In: HAYMAN, David. The "Wake" in Transit. [S.I.]: Cornell Univ. Press, 1990. p.36.
} 
capturados (ou pelo menos não capturados pelos mesmos aparatos gerais de captura) pode nos mostrar outras possibilidades de criar e de pertencer.

Fotografia 33 - Finnegans Ueinzz - Cia Ueinzz, 2009

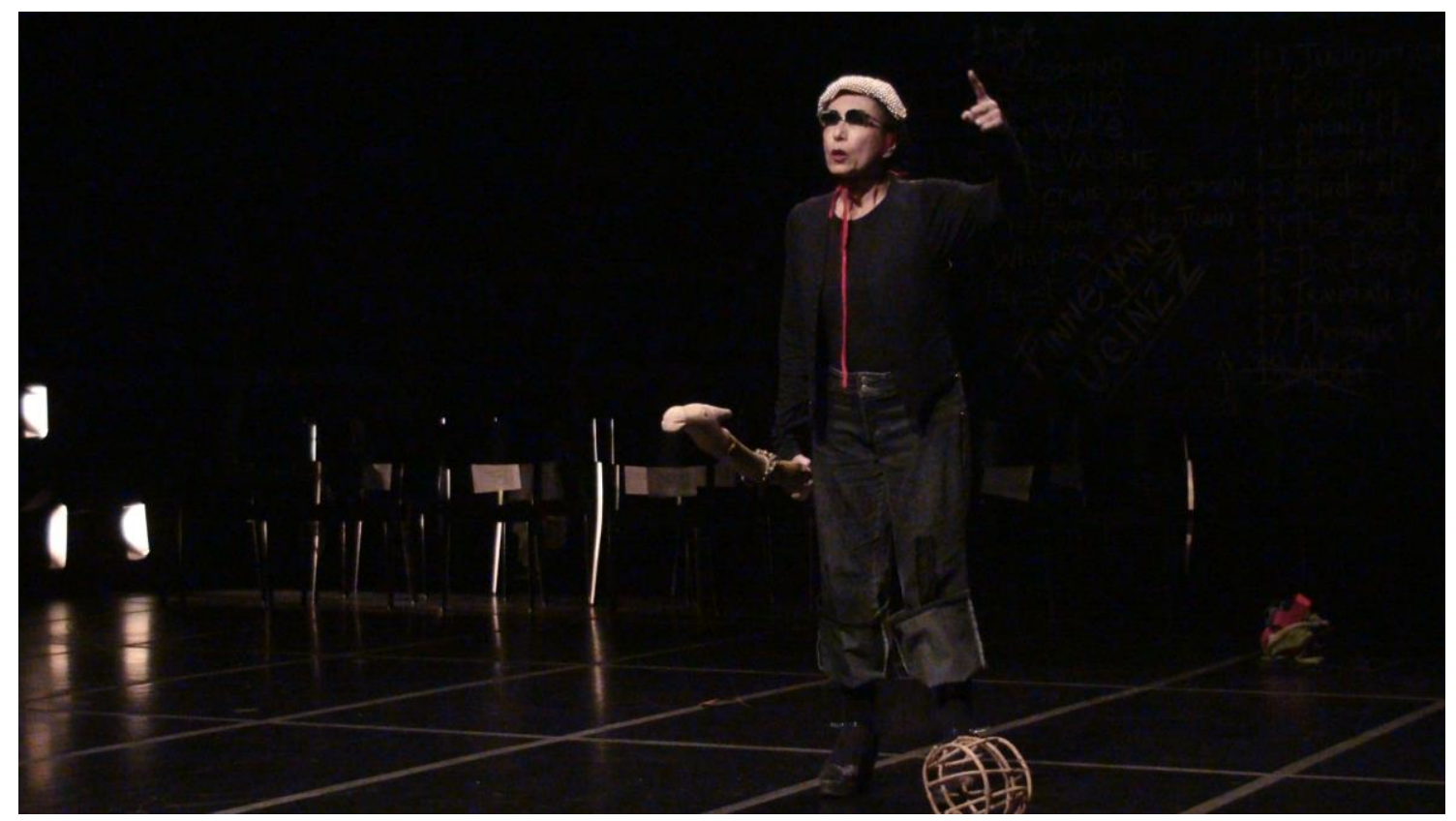

Iza Cremonine. Foto: Simone Mina.

\section{Encenação heterogênea}

A heterogeneidade não está presente apenas na percepção de temporalidades que se diferenciam a partir do vivido, como vimos no primeiro capítulo. Tampouco apenas na diversidade de pessoas, na possibilidade de diferirem de si mesmas, ou então na multiplicidade de procedimentos e dispositivos de criação, como vimos no segundo capítulo. Mas ela pode ser um fundamento da própria linguagem. O teórico e dramaturgo Benard Dort traz alguns elementos que podem ancorar nossa ideia de uma encenação heterogênea.

Ele investiga, na passagem do teatro moderno para o contemporâneo, como se deram algumas transformações das relações entre texto e cena - e posteriormente entre os elementos da cena - na composição de um espetáculo. Dort descreve como, ao longo do século $\mathrm{XX}$, a pessoa responsável pela direção de uma peça procurava criar uma obra em que os elementos cênicos convergiam para uma totalidade na qual as partes se encaixavam e se confirmavam. Porém, na segunda metade do século $X X$, começa pouco a pouco a haver um desmanche dessa ideia de unidade: 
[...] constatamos hoje uma emancipação gradual dos elementos da representação teatral e observamos uma mudança estrutural: a renúncia à unidade orgânica ordenada a priori e o reconhecimento do fato teatral enquanto polifonia significante, aberta para o espectador ${ }^{116}$.

Dort também descreve como a encenação (que chama de representação) foi se emancipando da vontade soberana do encenador:

Inicialmente o encenador foi o único a decidir sobre sua organização semântica. Agora os outros criadores do teatro reivindicam uma responsabilidade paralela e uma relativa autonomia. Texto, espaço, interpretação se emancipam. Assim se esboça uma nova concepção da representação. Ela não pretende mais uma fusão ou união das artes. Ela aposta, ao contrário, em sua independência dentro do espetáculo. ${ }^{117}$

Mais adiante, Dort analisa como essa "representação não unificada" era feita não somente da autonomia e da independência dos diversos elementos cênicos, mas também de seu tensionamento, ou embate, nomeando esse processo de uma concepção agonística de encenação ${ }^{118}$, não no sentido de agonia, mas de luta. É uma concepção de encenação na qual os elementos lutam entre si, de modo que a teatralidade seria feita do "deslocamento dos signos" 119 e de sua combinação impossível, e não de sua concordância. Assim, ele nos traz uma discussão que tem sido importante para se entender a cena contemporânea e que se conecta com as ideias vistas no inicio deste capítulo: o conceito de beleza discordante, não apaziguada, de Whitehead, e as análises de Deleuze sobre os filmes de Hans-Jürgen Syberberg, em que temos a sobreposição de camadas que vão em direções opostas, por exemplo entre som e imagem. Essas concepções, que vêm da filosofia, do cinema e do teatro, convergem para a divergência: a ideia de uma arte e um tipo de beleza que existem a partir do contrastante e não do apaziguamento, que produzem uma abertura de leituras, de entendimentos e produções de mundo e de sentido. Dort conclui: "Enquanto construção, a teatralidade é o questionamento do sentido" 120 .

\footnotetext{
${ }^{116}$ DORT, Bernard; UHIARA, Rafaella. A representação emancipada. Sala Preta, v. 13, n. 1, 2013, p.51.

117 Ibidem, p.53

118 Ibidem, p.54.

${ }^{119}$ Ibidem, p.55.

120 Ibidem, p.55.
} 
Como o crítico francês aponta, se ao longo do século $\mathrm{XX}$ o diretor procurava criar uma unidade, essa ideia foi se desfazendo e, já na segunda metade do século, podemos falar de heterogeneidades em diálogo, combate ou disputa, que engendram uma encenação que não está interessada em apaziguar ou em formar um todo harmonioso, ou mesmo em construir um sentido único.

Assim, voltando aos coletivos estudados nesta dissertação, percebo que nossos processos de criação instauram uma encenação heterogênea, que se espalha para além dos corpos e dos indivíduos. A heterogeneidade acabou se constituindo, para mim, como encenadora, um elemento de linguagem, de composição dramatúrgica e de encenação. Esse pensamento se dá em algumas camadas (que existem e se alimentam simultaneamente):

1. A encenação é heterogênea se pensarmos nos procedimentos e dispositivos de criação, vindos de variadas linguagens e áreas, como: diferentes tipos de dança, butoh, teatro, psicanálise, filosofia, performance, artes visuais etc.;

2. Essa encenação híbrida une pontos disparatados que não são somente elementos diferentes, mas elementos de campos de referências e imaginários diferentes;

3. Os espetáculos que criamos têm várias dimensões: históricas, afetivas, clínicas, estéticas, sociais, micropolíticas. Qualquer espetáculo pode ter essas dimensões, mas elas ficam evidentes quando há um elenco de corpos que se desviam de um padrão de "normalidade".

Além dos estudos de caso relatados durante a dissertação nos quais podemos ver as práticas e criações que constituem essa encenação heterogênea, gostaria de acrescentar dois exemplos, das áreas de sonoplastia e figurino, do espetáculo Do outro lado do oceano. (Criei a sonoplastia com a colaboração de Peri Pane e Nicholas Wahba, e figurino com a colaboração de Marina Reis, Evelyn Eduardo e de todo o elenco.)

$\mathrm{Na}$ sonoplastia, criamos uma colagem que incluía texturas sonoras não melódicas feitas por computador, trechos da música "brega-cult" "Piranha", de Alípio Martins, trecho de músicas pop americanas da banda Bom Iver, música 
clássica, trecho de canção de músicos de rua da Ucrânia e uma banda tocando dixieland ao vivo. Ou seja, aqui temos uma dramaturgia sonora que foi elaborada a partir de elementos contrastantes, heterogêneos.

Nos figurinos, havia uma inspiração inicial no filme La nave va, do cineasta Frederico Fellini, mas assim como nos procedimentos de criação, a paleta também incorporava desvios: conviviam no espetáculo roupas de época, um ator vestido de fraque e bermuda, roupas de hippie dos anos 1970, vestido de veludo do século XVIII, terno, escafandro, camiseta de caveira, vestido de gala com lantejoulas vermelhas, coletes salva vidas etc. Nessa diversidade de roupas, havia uma tessitura, e cada figurino foi cuidadosamente pensado ${ }^{121}$.

É importante lembrar que a ideia de uma encenação heterogênea não quer dizer que vale tudo. Mesmo com a aparente profusão de elementos nos exemplos citados, há uma criação dos próprios parâmetros: tanto das obras criadas, quanto das dinâmicas dos encontros. Por mais que os processos sejam feitos de modo a acolher as dissonâncias, as assimetrias e os desvios, há uma tessitura estética e existencial sendo feita por meio da heterogeneidade. Não é uma tessitura lisa ou harmônica, mas feita de fricção, composta de fios diferentes, que faz um tecido que não é plano, nem achatado, mas rugoso, feito de diferentes espessuras e materiais. Os elementos não estão costurados, mas tramados de modo a criar alguma estrutura, algum chão, mas que não é o chão da unidade ou da harmonia. Félix Guattari traz reflexões que nos ajudam a pensar uma encenação heterogênea:

Todo descentramento estético dos pontos de vista, toda multiplicação polifônica dos componentes de expressão, passam pelo pré-requisito de uma desconstrução das estruturas e dos códigos em vigor [...], a partir das quais tornarse-á possível uma recomposição, uma recriação, um enriquecimento do mundo (um pouco como se fala de urânio enriquecido), uma proliferação não apenas das formas mas das modalidades de $\operatorname{ser}^{122}$.

\footnotetext{
${ }^{121}$ Dentro das possibilidades de recursos: mostramos fotos do filme ao elenco, para que eles trouxessem propostas a partir de uma ideia de viagem de navio; também alugamos algumas roupas ou compramos em brechós. Além disso, a Ser em Cena tem parceria com uma loja de fantasias, o que não somente é levado em conta na criação do espetáculo, como também estimula a criação de algumas cenas.

${ }^{122}$ GUATTARI, 1992, p.115.
} 
Ao trabalhar com esses coletivos, para buscar essa "recomposição" e "proliferação das formas e das modalidades de ser", para além da linguagem heterogênea da encenação, também o meu processo como diretora terá que ser feito por um viés heterogêneo, no sentido de diferir de mim mesma, "me deixar desestabilizar pela alteridade"123, entender as necessidades de cada processo, e lidar com a multiplicidade de elementos - humanos, temporais, logísticos, processuais, fisiológicos, materiais etc. - que se apresentam. Cada coletivo, e cada trabalho ou processo criativo irão suscitar seu método próprio: "são novas maneiras de ser do ser que criam os ritmos, as formas, as cores, a intensidade da dança"124.

${ }^{123}$ Ibidem.

124 Ibidem, p.119. 
APÊNDICE - MÉTODO SEM MÉTODO 
Reuni alguns procedimentos e dispositivos de criação que foram experimentados nesses dezessete anos de trajetória com diferentes coletivos. Esse compêndio nasceu nos encontros e nas práticas, por meio de experimentação, tentativa e erro. São procedimentos que vieram do teatro, da performance, da dança, das artes visuais, da música e da vida em geral. Sem querer ser bula ou receita, é uma coleção sedimentada aos poucos, por descoberta, invenção ou recriação, em uma junção de estética, clínica e pedagogia que tem sido útil na elaboração e criação de espetáculos e performances. Compartilho aqui essa cartografia ainda e sempre em construção de alguns dos mapas que temos criado e que tentam inventar territórios.

\section{ANTENAGEM}

1. Estar de antenas abertas para o que surge fora do horário oficial.

2. Estar atenta às irrelevâncias, elas escondem outro tipo de relevância.

3. Estar atenta ao material que surge por acaso, é possível criar uma cena com quase nada, com indícios, com o que aparece.

4. Estar atenta é estar distraída, permeável.

6. A antenagem às vezes pode ser interrompida: Sebastian me deu um dicionário quéchua, o mapa de onde ele veio e a cópia dos seus documentos. Um papel dobrado e dobrado novamente, tirado amarrotado do bolso com um circulo preto quase apagado, um lugar do Panamá. Guardei para um dia. Ele morreu antes. Às vezes coloco cúmbias nas aulas. Mas naquela turma era para ele, para ver uma alegria só possível de alguém com aquelas latitude e longitude.

\section{Ver Tatear-junto.}

\section{ENCAIXES}

1. Estar aberto para encaixes não óbvios quando for criar a sequência das cenas.

2. Ou óbvios, se esta for a proposta. 
3. De qualquer modo, estar aberto para as possibilidades de encaixe das cenas, que pode acontecer por sobreposição, contraste, ritmo, densidade, tema etc.

4. Ilhas: podem haver ilhas de linearidade dentro da obra, em vez de se submeter tudo a uma lógica linear ou causal.

5. Criamos uma cena de montanha-russa em uma improvisação. Havia as cenas: seis modos de começar um amor e cinco modos de terminar um amor, anunciadas por seus títulos. A montanha-russa entrou depois dessas duas, com o título: o amor. Não sei se é um exemplo de encaixe óbvio ou não óbvio, mas é um bom exemplo de encaixe.

Fotografia 34 - Cena: O amor. Silêncios, moléculas, dinossauros - Ser em Cena, 2018

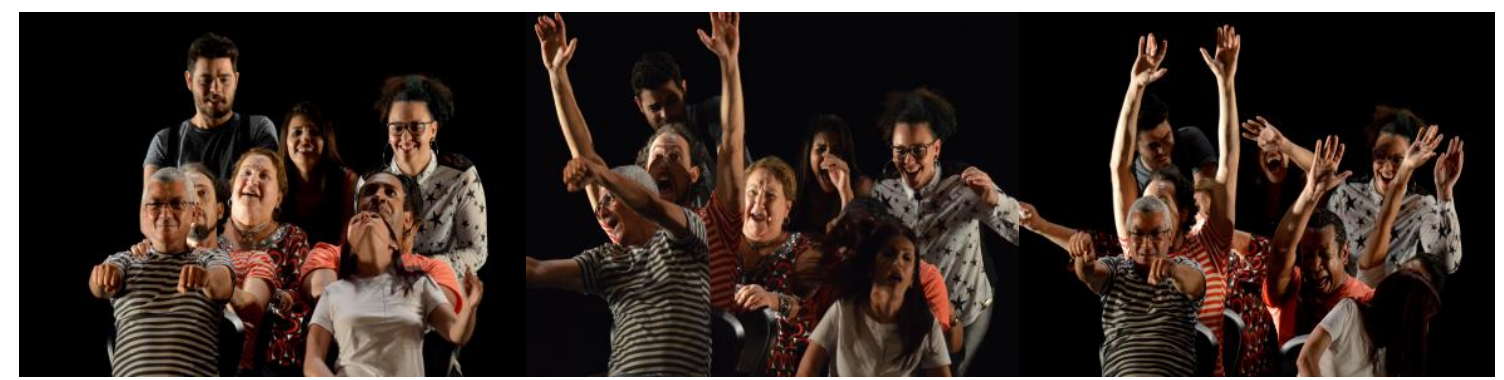

Da esquerda para direita, de cima para baixo: Marcos Mariano, Danielah Paulino, Carol Coelho, Fernando Falci, Neusa Moratore, Cayo Eduardo, Jansen Cavalcanti, Paula Maia. Foto: Fábio Barrocal.

\section{LISTAS}

1. A lista é um jeito de lidar com um número grande de pessoas de modo a preservar as singularidades de cada uma na criação de uma cena. Um dispositivo que acolhe diferenças e permite a convivência dos mais diversos elementos no mesmo conjunto. Em uma lista, não são os itens disparatados que chamam a atenção, mas o elemento agenciador que cria um plano de coexistência desses itens; afinal onde mais um dente de leite estaria ao lado de Constantinopla e de um peito? "Sabe-se o que há de desconcertante na proximidade dos extremos ou, muito simplesmente, na vizinhança súbita das 
coisas sem relação; a enumeração que as faz entrechocar-se possui, por si só, um poder de encantamento" 125 .

2. Lista de cenas de lista:

a) Coisas que caem: dentes, fruta, Constantinopla, peito, torre gêmeas;

b) Jeitos de cair depois de enunciar as coisas que caem;

c) 24 tipos de silêncio: parque em Santana, telefone que não toca, paz, um documento que sumiu, confissão, sem graça no elevador etc.;

d) xingamentos ${ }^{126}$.

3. No espetáculo Do outro lado do oceano, havia uma cena chamada embarque. Cada pessoa atravessava o palco e em algum momento parava, olhava para o público e continuava rumo ao embarque. Quem quisesse poderia se deslocar de um modo diferente do habitual. As 75 pessoas do elenco participavam. Imagino que a multiplicidade dos jeitos de atravessar tem vizinhança com a lista. Havia uma moldura ficcional mínima - atravessar o palco, parar e olhar - sem um denominador comum achatante. Diferentes registros de interpretação conviviam lado a lado no fluxo ininterrupto: introspecção stanislavskiana, jeito brincalhão, um que caminha assustado como que fugindo de algo, outra que quase chora e cria um personagem que vai embora para sempre, outro que corre na ponta dos pés, duas que dançam e rodopiam, outra que se esgueira como se estivesse em um filme expressionista alemão, ao lado de um senhor que procura alguém entre as pessoas, ou de outra que dá tchau aos amigos do público no meio da cena.

4. Outros motivos pelos quais a lista é importante: 4.1. Pode conectar um ponto a outro pelo desejo. 4.2. Modo de passar o tempo durante um medo (acalma) 4.3. Acalma porque dá a sensação que as coisas estão, pelo menos um pouco, ou por um tempo, sob controle.

\section{PENEIRA}

Lapidar a escuta para poder discernir e ouvir da melhor forma possível em cada caso: palpites, sugestões, pitacos, devolutivas, feedbacks, impressões, opiniões, achismos, considerações, leituras, críticas construtivas,

\footnotetext{
${ }^{125}$ FOUCAULT, Michel. As palavras e as coisas. São Paulo: Martins Fontes, 2016. p.X.
}

${ }^{126}$ A, b, d: espetáculo Finnegans Ueinzz. C: espetáculo Silêncios, moléculas, dinossauros. 
críticas destruidoras, ideias, provocações, propostas, pedidos, súplicas, ordens, insinuações, indiretas.

\section{QUADROS}

1. Também chamado de sketches, ou tableau.

2. Uma estrutura de cenas independentes, que surgem a partir do tema geral pensado para o espetáculo e que serão dispostas na obra a partir de outros elementos que não um encadeamento linear.

3. Uma "composição de signos gestuais que se constitui numa ilha de sentido: correspondendo a uma pausa no avanço em arrancos da ação dramática." 127

4. A estrutura de quadros permite se pensar a dramaturgia musicalmente (alternância de ritmos ou andamentos) ou espacialmente (storyboard).

\section{REINO-DO-TUDO-JUNTO ${ }^{128}$}

1. Também chamado de colagem, montagem, simultaneismo.

2. Não ter medo da heterogeneidade de elementos, "vale qualquer coisa, mas não de qualquer jeito" 129 .

3. "A lógica do simultaneismo, [reino-do-tudo-junto] no entanto, se é que tem uma lógica, não tende discretamente a uma resolução hegeliana de opostos. Requer que nossas mentes abarquem simultaneamente e sem síntese duas ou mais proposições contraditórias. (Neste sistema, são possíveis mais de duas.)"130

4. Colagem e montagem: "Embora as fronteiras entre esses dois conceitos sejam relativamente difusas, [...] nem por isso é impossível

\footnotetext{
${ }^{127}$ SARRAZAC, Jean-Pierre (org.). Léxico do drama moderno e contemporâneo. São Paulo: Cosac Naify, 2012. p.176. Para quem quiser se aprofundar nesse verbete, consultar o verbete Tableau (quadros) e também o verbete montagem/colagem (p.119).

${ }^{128}$ SHATTUCK, Roger. The Banquet Years: the Origins of the Avant Garde in France, 1885 to World War I: Alfred Jarry, Henri Rousseau, Erik Satie [and] Guillaume Apollinaire. [S.I.]: Vintage, 1968. p.349. Agradeço Silvia Fernandes pelas considerações feitas sobre esse procedimento em minha qualificação.

${ }_{129}$ Tiche Vianna durante as aulas na Unicamp, 1997.

${ }^{130}$ lbidem.
} 
estabelecer distinções. A montagem sugere a ideia de uma descontinuidade temporal, e a colagem, por sua vez, evoca a justaposição espacial de materiais diversos.

"Na prática teatral, a montagem e a colagem não são apenas técnicas de escrita, elas supõem também uma maneira de encenar, agenciar a luz, a música, a atuação... e sobretudo de deixar a obra de arte aberta (para o exterior, a atualidade), apta a integrar o acaso, o imprevisto e vislumbrar uma profusão de possíveis."131

Fotografia 35 - Do outro lado do oceano - Ser em Cena, 2016

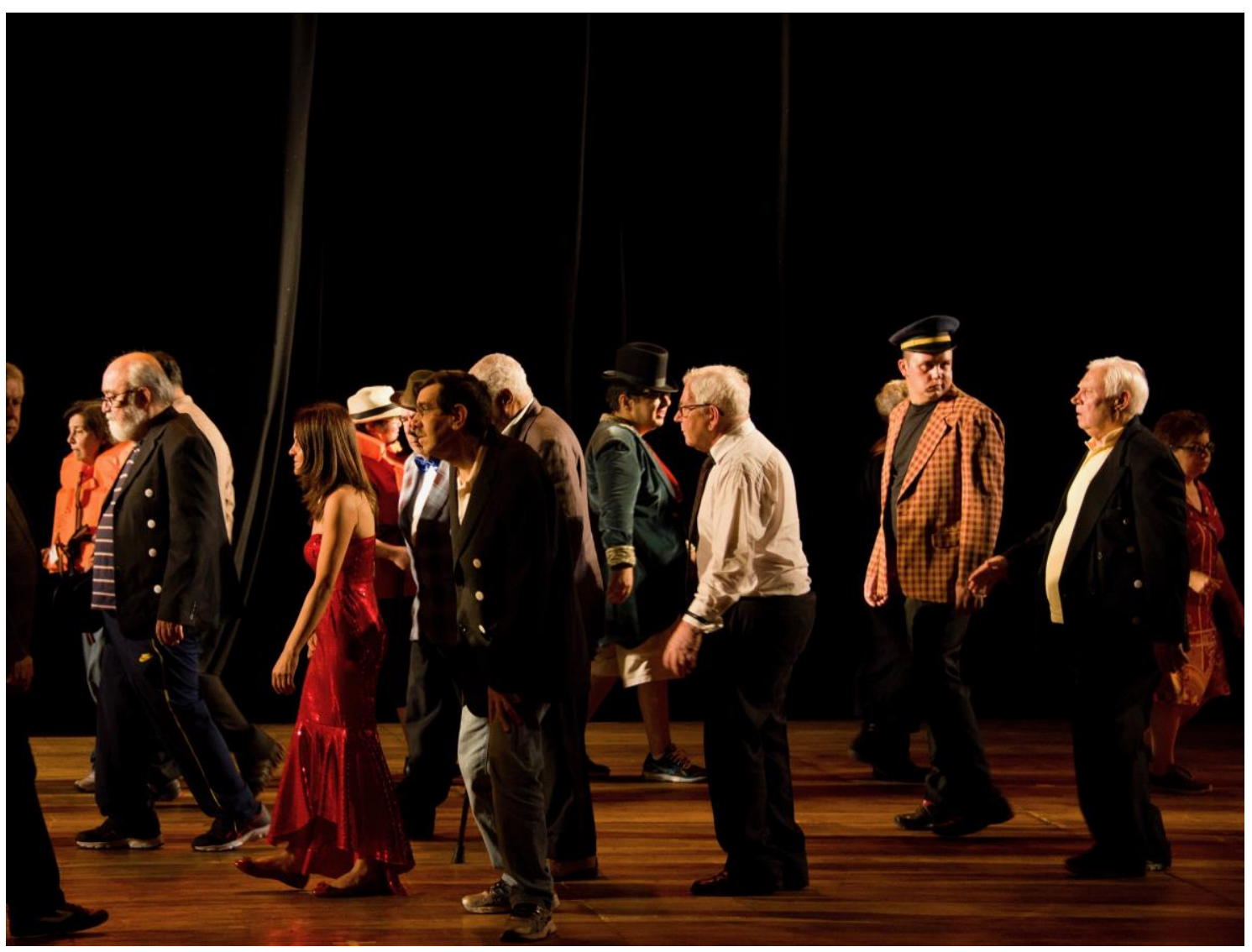

Da esquerda para direita: Antônia Ukon, José Lopes Ribeiro, Rita Gallo, Joaquim Falleiros, Victor Hugo (de chapéu), João Correa, Michael Aguiar, Edson Branco. Foto: Karina Bacci.

\section{RITMO}

Na criação de uma dramaturgia não ancorada em uma história linear, pensar no ritmo do espetáculo como um todo, composto por diferentes andamentos, pode ser um possível elemento norteador. Há o ritmo do andamento de cada cena e a composição destes andamentos. É uma escuta

${ }^{131}$ SARRAZAC, 2012, p.120. 
musical que organiza esse ritmo do espetáculo: independente do tema, qual o ritmo de cada cena? O que acontece ao se colocar em sequência duas cenas explosivas, ou duas cenas com o andamento parecido? E se essas cenas semelhantes forem distribuídas de modo a criar um percurso mais nuançado e com ritmos diferentes que se alternam?

\section{SILÊNCIO}

Momentos em que nada acontece. Deixar acontecer momentos em vazios. Detectar os tipos de silêncio (que são mais do que 24).

\section{STORYBOARD}

É um modo visual de organização das cenas: assim, é possível experimentar ordens e relações entre elas, por meio da disposição dos elementos no espaço (pessoas, cenários e objetos). Pensar a espacialidade por meio de desenhos se complementa com a organização do ritmo do espetáculo. Fazer esse procedimento conjunto (ritmo + desenhos + texto) amplia as possibilidades de criar sentidos.

\section{TATEAR JUNTO}

Criar espaços para a indeterminação, a errância. Acolher o inesperado, e prestar atenção, pois muitas vezes é de algo sutil que surge o material para a criação. Ver ANTENAGEM.

\section{TEMA ABERTO}

1. Começar por um tema aberto (que pode ou não conter uma história) permite que se desenvolva o processo de criação a partir das especificidades do elenco. Esse dispositivo é relacionado à estrutura de quadros e ao verbete das listas. Em um tema aberto, cabem vários personagens, tramas e subtramas, reviravoltas e cenas abstratas. 
2. É bom ampliar territórios e tentar inventar um mapa próprio dentro do tema aberto. Amor e morte nunca saem de moda mas podem estar contidos em agenciamentos mais específicos.

3. No espetáculo Silêncios, moléculas, dinossauros, há uma aparente coerência dada por uma cena inicial que descreve um manuscrito cujas partes teriam sido encontradas em diferentes lugares e tempos. Essa invenção permite o surgimento de elementos os mais diversos, como tremeliques, uma aula sobre moléculas e dinossauros, ou um a revolta de um bailarino.

\section{4. ver LISTAS.}

\section{VARIÁVEIS EXTERNAS}

Locomoção, improvisos sem fim, necessidade de ajuda com orientação espacial, mudança de ideia, falta de recursos (físicos, financeiros, emocionais, libidinais), pandemia, possibilidade de não fazer, aparições e desaparições inesperadas: criar levando em conta essas variáveis.

Fotografia 36 - Do outro lado do oceano - Ser em Cena, 2016

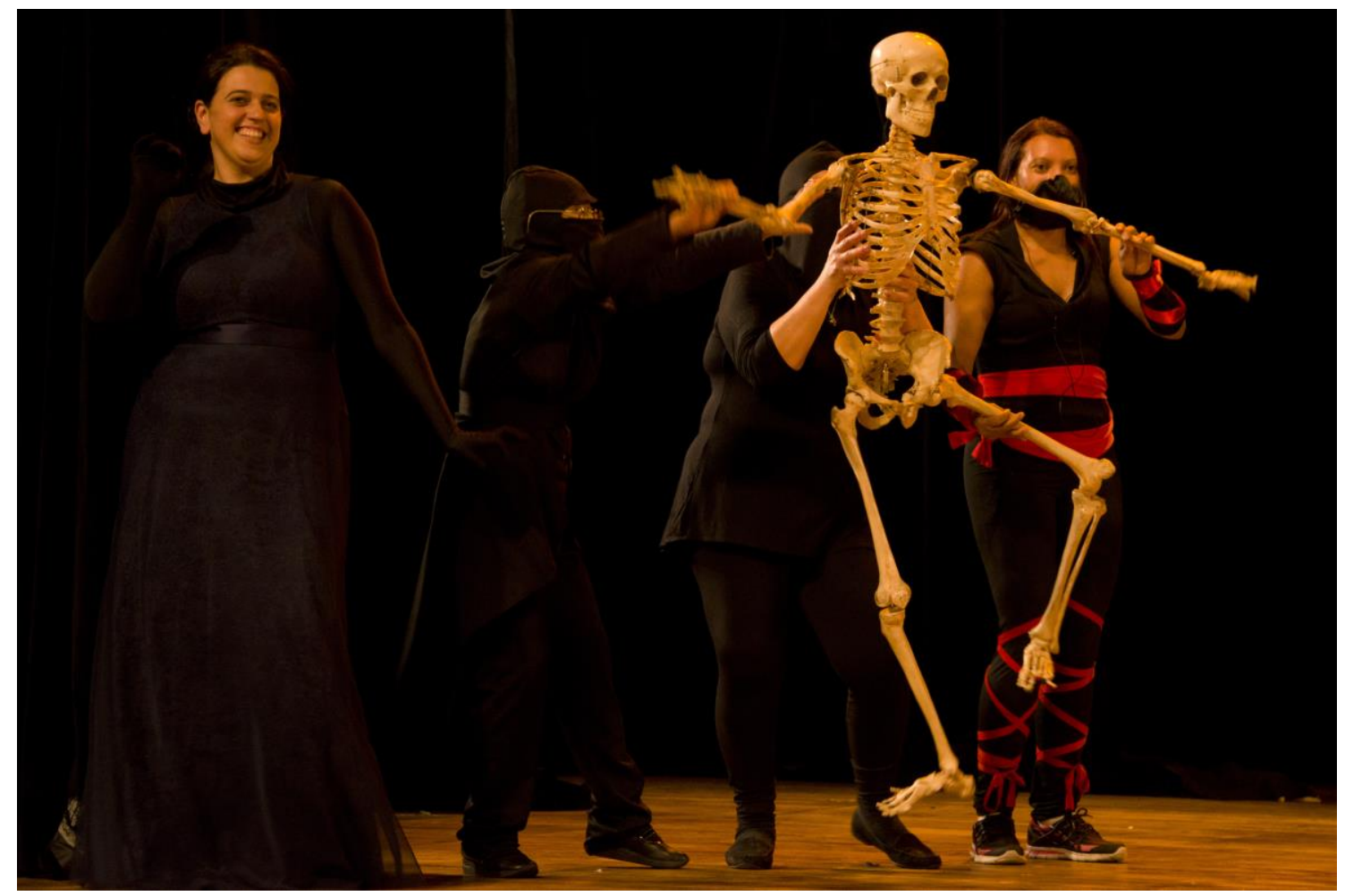

Michele Aied e elenco da Ser em Cena. Foto: Karina Bacci. 


\section{ERRÂNCIAS FINAIS}


Compartilho aqui uma coleção de apontamentos que vão em direções diferentes, a partir do vivido e também de mundos que possam ganhar consistência. Nessas errâncias finais alinhavo pensamentos que não pretendem concluir. É um texto para escrita e cena deixarem novamente de coincidir, enquanto continuamos tentando inventar, nesta e naquela, jeitos de que nos deem mais vida.

Comecei pelas bordas, fui lembrando momentos importantes com os coletivos, mas achava que em algum momento iria perceber melhor onde situar os casos investigados em relação ao que surgiria. Por se tratar de um percurso cronológico específico, quando triasse o material completo (cadernos, arquivos e vídeos), apareceriam todos os temas e casos a serem analisados. Mas, à medida que selecionava, os acontecimentos se desdobravam para dentro, se abrindo ao infinito, de modo que percebi, em certo momento, que seria uma ilusão conseguir "cobrir tudo". Em vez de pensar em bordas e centro, a ideia de fazer uma cartografia - escolher um percurso dentro desse infinito - foi uma estratégia que se mostrou mais adequada. Assim, pude escolher um material significativo, aprofundar-me nesse material e, ao mesmo tempo, lidar com o fato de que sempre tem mais.

Não sei quanto consegui de equilíbrio entre a costura das distâncias e proximidades: por um lado, me distanciar para analisar as próprias experiências e, por outro, conseguir olhar de perto para perceber outros pontos de vista e ampliar os conhecimentos.

Esta pesquisa abre algumas possibilidades. A primeira é olhar para fora, falar de outros grupos que trabalham com diferentes tipos de heterogeneidade, ver como lidam com a instauração de linguagens a partir de singularidades, como essas outras criações se relacionam e dialogam ou não com o que fazemos. A segunda possibilidade, que se relaciona com a primeira, é aprofundar o diálogo entre os nossos processos de criação e alguns conceitos da cena contemporânea (como a questão da presença e os elementos constituintes de uma encenação heterogênea), assim como com artistas que repensaram o lugar da arte e migraram para uma área híbrida, como Lygia Clark. 
Outra possibilidade é um desejo de voltar para a prática com nossos coletivos, depois desta investigação e desta travessia, e continuar a experimentar formas de reinvenção de estéticas e de éticas aprofundando ainda mais em uma busca de uma linguagem não domesticada ou domesticadora, mas, ainda assim, que comunique e irradie diferentes construções de sentido. Assim como esta pesquisa foi transformadora, acredito e desejo que também as criações possam ser transformadas.

Outras possibilidades incluem dormir três dias, respirar ar puro das montanhas, dançar como a Julie Andrews do meio daquela montanha, entrar na piscina de plástico, boiar no tanque aquático sem som e sem luz, fazer fotossíntese, me esparramar numa pedra perto da cachoeira para sempre. Respirar. Deitar olhando para o teto durante dias semanas meses. Dormir, dormir, dormir. Acordar ano que vem, quando já tiver acontecido a defesa a vacina e a queda do capitalismo, tiver chovido e secado várias vezes e a cidade acordar coberta de plantas.

Termino esta reflexão percebendo uma ampliação de território, depois de metabolizar essas experiências, mas ao mesmo tempo sem saber o que vai ser de tudo isso. É um território feito de indeterminação e instabilidade. No momento, estamos todos tentando descobrir jeitos de viver o presente e de imaginar futuros. O que quer que aconteça no mundo, não vai ser uma volta. $O$ que quer que aconteça, vai se tratar de uma reinvenção. Essas expressões soam familiares. Além do aspecto estético, de criação de linguagem, já analisado durante toda a dissertação, a tentativa de reinvenção é um universo já conhecido de muitas das pessoas dos nossos coletivos. Sobreviver depois do desastre. Mais do que imaginar que temos coisas a ensinar sobre a vida ou a realidade, talvez nós é que tenhamos que aprender com nossas atrizes a atores algo sobre a reinvenção de linguagem, de vida e de tempo. Ou reconstrução de si ${ }^{1}$. Não que muitas pessoas já não tentem isso em menor ou

\footnotetext{
${ }^{1}$ Segundo Laís Barreto Barbosa (comunicação pessoal), que em processo de pesquisa de doutorado, "para o autor [Oury] a criação artística é um processo de reconstrução de si mesmo, 'trata-se para um esquizofrênico de lutar contra o que é específico da psicose: uma estrutura fechada' (OURY, Jean. Création et schizophrénie. Paris: Éditions Galilée, 1989. p. 93, tradução nossa). A criação da obra e o processo criativo são a tentativa desta reconstrução de si mesmo".
} 
maior intensidade, mas em alguns momentos fica mais evidente que temos que achar outros jeitos.

Em um mundo cada vez mais acelerado e "instagramável", em que existências são validadas por uma valorização de imagens relacionadas à certa ideia de beleza, juventude, saúde e bem-acabamento, imaginar e experimentar outras formas de relação é não se submeter ao oficial, ao vigente, ao estabelecido e ao algoritmo. O que ancora o percurso com os coletivos, assim como a escrita desta dissertação, é uma vontade de desancorar, diferir de mim mesma, outrar. Esse não é um gesto simples, pois muitos de nossos gostos e comportamentos são heranças pré-formatadas, então se trata de desnaturalizar o que parecia natural, na arte e na vida.

Retomo o relato do final do segundo capítulo, do pescador que pescou um peixe tão grande que só a foto pesava 38 quilos. A carreta que carregava o bicho explodiu e carbonizou o peixe, e ninguém acreditava na história. O pescador decidiu então chamar algumas pessoas para fazer uma viagem, dessa vez em alto mar, pescar um peixe maior ainda e tentar descobrir o sentido da vida. Em uma das últimas cenas do espetáculo, ele falava que não encontrou o peixe nem o sentido da vida, mas descobriu uma receita de tilápia deliciosa. Se eu for encenar essa peça novamente não falaria em receita, mas que ele comeu um peixe delicioso. Nossas investigações e estudos de caso têm um pouco desse peixe. Sem receita, ponto de chegada (achar um peixe maior ainda) ou procura de sentido transcendente, os próprios modos com que escolhemos passar o tempo já são o que buscamos. Assim, comer um peixe não é tentar achar o sentido da vida, mas os sentidos de uma vida, e de uma vida que não promete transcendência, melhoria ou está em débito com um futuro ideal, seja de linguagem ou de corpo, mas que experimenta a potência do agora e os sentidos que surgem daqui.

\footnotetext{
${ }^{2}$ Renan Marcondes, performer e pesquisador, fez um mestrado em Poéticas Visuais na Unicamp sobre a relação entre corpo e objeto na arte da performance, e desenvolve, neste momento, um doutorado na ECA-USP sobre as questões de presença e performatividade em um contexto neoliberal de hipersaturação de imagens.
} 
Nesta dissertação, analisei alguns processos de criação. Para realizar esta investigação, relatei no primeiro capítulo o surgimento de cada experiência, coletando inícios e percebendo que havia sempre um antes, de modo que essa escavação temporal levou ao questionamento da própria ideia de começo.

Aproximando-me do final desta escrita, surge a pergunta: e quando é que alguma coisa termina?

Uma garrafa jogada no mar com uma mensagem dentro. Um corpo que se decompõe e vira terra que vira planta. Células que vivem e morrem dentro da vida de uma mesma pessoa. A luz de uma estrela que não existe mais. A comida depois de comida. Cogumelos que nascem apenas em lugares que sofreram colapso e devastação. Pé de galocha que vira vaso. Caroço que renasce. Palavra que vira ato.

Alguns eventos não cessam de se transformar e continuam instaurando inícios. Ou, dentro da ideia de tempos que coexistem, várias possibilidades podem conviver em um mesmo acontecimento. Se desmancharmos a imagem de uma "linha do tempo", libertamos o vivido de sua narrativa cristalizada.

Ou então um prazo pode ser um elemento organizador. Assim como uma data de apresentação ou de uma filmagem também são uma espécie de ponto final, mesmo que sejam uma abertura de processo. Mas para além dos espetáculos, experimentos ou produtos finais, como algumas das experiências relatadas terminaram?

Elas terminaram como as coisas em geral chegam ao fim, mais ou menos calmas, mais ou menos turbulentas, às vezes um final de ciclo necessário, outras vezes um corte abrupto. Geram tristeza ou alívio, ou ambos, e se transformam em outras coisas. Que outros mundos podem surgir de cada experiência? Não sei. Por enquanto, o que posso dizer é que a Aláit não apareceu mais, e os meus oito anos chegaram ainda que eu tenha evitado a festa. 


\section{REFERÊNCIAS BIBLIOGRÁFICAS}

ABBAGNANO, Nicola. Dicionário de Filosofia. São Paulo: Martins Fontes, 2003.

ALVES, Camila Araújo; MORAES, Márcia. Entre histórias e mediações: um caminho para acessibilidade estética em espaços culturais. Psicologia: Ciência e Profissão. Brasília, v. 38, n. 3, set. 2018, p.584-594. Disponível em $<$ http://www.scielo.br/scielo.php?script=sci_arttext\&pid=S141498932018000300584\&lng=pt\&nrm=iso >. Acesso em: 3 jul. 2020.

AMERICAN PSYCHIATRIC ASSOCIATION et al. Manual diagnóstico e estatístico de transtornos mentais: texto revisado (DSM-IV-TR). [S.I.]: Artmed, 2002.

ABECEDÁRIO de Gilles Deleuze, O. [on-line]. Entrevista concedida a Claire Parnet. Escrito por Bernardo Rieux. Produzido por Éditions Montparnasse, Paris, 1988-89. Transcrição integral do vídeo, para fins exclusivamente didáticos. Disponível em: <http://stoa.usp.br/prodsubjeduc/files/262/1015/Abecedario+G.+Deleuze.pdf>. Acesso em: 9 jun. 2019.

AUSLANDER, Philip. From Acting to Performance: Essays in Modernism and Postmodernism. [S.I]: Routledge, 2002.

AGAMBEN, Giorgio. O que é o contemporâneo? e outros ensaios. Chapecó: Argos, 2009.

BAND, Elisa. Sonhos. Revista Vocare, ano1, n. 1, nov. 2011. p.45. Disponível em: <https://docero.com.br/doc/n515ne0>. Acesso em: 15. jul. 2020.

BERGSON, Henri. A evolução criadora. Rio de Janeiro: Opera Mundi, 1971.

Matéria e memória: ensaio sobre a relação do corpo com o espírito. São Paulo: WMF Martins Fontes, 2010.

BIALER, Marina. Ensinamentos dos esquizofrênicos para o tratamento institucional das psicoses. Estilos clin., São Paulo, v. 21, n. 3, p.657-670, dez. 2016.

Disponível

em

<http://pepsic.bvsalud.org/scielo.php?script=sci_arttext\&pid=S1415-

$71282016000300006 \&$ Ing $=p t \& n r m=i s o>$. Acesso em: 3 jul. 2020.

BISHOP, Claire. Artificial Hells: Participatory Art and the Politics of Spectatorship. [S.I]: Verso Books, 2012.

BORGES, Jorge Luís. Atlas. São Paulo: Companhia das Letras, 2010.

BOROVIK, Samira S. B. KA: a sombra da alma: performance e xamanismo no espetáculo de Renato Cohen. São Paulo: Annablume, 2014. 
BOURRIAUD, Nicolas. Estética relacional. São Paulo: Martins Fontes, 2009.

BRANDÃO, Ignácio de Loyola. Do outro lado do oceano. O Estado de S.Paulo, 14 abr. 2017, Caderno 2, p. C6.

BRYSON, Bill. Breve história de quase tudo. São Paulo: Companhia das Letras, 2005.

CAMPBELL, Joseph. A Joseph Campbell Companion: Reflections on the Art of Living. New York: Joseph Campbell Foundation, 2011.

.; ROBINSON, Henry Morton. Introdução a um assunto estranho. In: CAMPOS, Augusto de; CAMPOS, Haroldo de. Panaroma do Finnegans Wake. São Paulo: Perspectiva, 2001.

CARVALHAES, Ana Goldenstein. Persona performática: alteridade e experiência na obra de Renato Cohen. São Paulo: Perspectiva/Fapesp, 2012.

COELHO, Marcelo. Atores com afasia mostram a difícil viagem da sobrevivência em peça. Folha Online, 21 dez. 2016. Disponível em: <https://www1.folha.uol.com.br/colunas/marcelocoelho/2016/12/1843234-

atores-com-afasia-mostram-a-dificil-viagem-da-sobrevivencia-em-peca.shtml>. Acesso em: 9 jun. 2019.

COHEN, Renato. Performance como linguagem. São Paulo: Edusp/Perspectiva, 1989. 1998.

Work in progress na cena contemporânea. São Paulo: Perspectiva,

CORNAGO, Oscar; FERNANDES, Sílvia; GUIMARÃES, Julia (orgs.). O teatro como experiência pública. São Paulo: Hucitec, 2019.

DELEUZE, Gilles. A imagem-tempo: cinema 2. Brasiliense, 2005.

. Crítica e clínica. São Paulo: Editora 34, 1997.

; GUATTARI, Félix. Devir-intenso, devir-animal, devir-imperceptível. In: Mil platôs. v. 4. São Paulo: Editora 34, 1997. p. 11-113.

; O anti-Édipo. São Paulo: Editora 34, 2010.

DELIGNY, Fernand. 0 aracniano e outros textos. São Paulo: N-1 Edições, 2015.

DIÁLOGOS na Mário: encruzilhadas. Evento on-line, disponível em: $<$ https://www.youtube.com/watch?v=8SsWv1hDEGk>. Acesso em: 28 jul. 2020.

DICIONÁRIO Básico Portuário [on-line]. Disponível em: <http://www.portosdoparana.pr.gov.br/Pagina/Dicionario-Basico-Portuario>. Acesso em: 30 mar. 2020. 
DORT, Bernard; UHIARA, Rafaella. A representação emancipada. Sala Preta, v. 13, n. 1, p.47-55, 2013.

DUNKER, Christian Ingo Lenz. Reinvenção da intimidade: políticas do sofrimento cotidiano. São Paulo: Ubu, 2017.

ECO, Umberto. Confissões de um jovem romancista. São Paulo: CosacNaify, 2014.

FABIÃO, Eleonora. Performance e teatro: poéticas e políticas da cena contemporânea. Sala Preta, n. 8, 2008, p.235-46. DOI: https://doi.org/10.11606/issn.2238-3867.v8i0p235-246.

FERNANDES, Sílvia. Teatralidades contemporâneas. São Paulo: Perspectiva, 2010.

Performatividade e gênese da cena. Rev. Bras. Estud. Presença, Porto Alegre, v. 3, n. 2, ago. 2013, p.404-19. Disponível em: $<$ http://www.scielo.br/scielo.php?script=sci_arttext\&pid=S2237-

26602013000200404\&Ing=en\&nrm=iso>. Acesso em: 7 jul. 2020.

.; GUINSBURG, Jacog (orgs.). O pós-dramático: um conceito operativo? São Paulo: Perspectiva, 2013.

FOUCAULT, Michel. As palavras e as coisas. São Paulo: Martins Fontes, 2016.

. História da loucura. São Paulo: Perspectiva, 1993.

O corpo utópico, as heterotopias. Trad. Salma T. Muchail. São Paulo: N-1 Edições, 2013.

- Sobre a história da sexualidade. In: Microfísica do poder. Rio de Janeiro: Graal, 2000.

FREUD, Sigmund. O estranho. In: Uma neurose infantil e outros trabalhos. Rio de Janeiro: Imago, 1976. (Edição Standard Brasileira das obras completas de Sigmund Freud, vol. 17.)

. Afasias. Rio de Janeiro: Jorge Zahar, 2014.

GARCIA-ROZA, Luiz Alfredo. Sobre as afasias, o projeto de 1895. Rio de Janeiro: Jorge Zahar, 2001.

GREINER, Christine. O corpo em crise, novas pistas e o curto-circuito das representações. São Paulo: Annablume, 2010.

Corpo: pistas para estudos indisciplinares. São Paulo: Annablume, 2005. Edição Kindle.

.; AMORIM, Cláudia. Leituras do corpo. São Paulo: Annablume, 2003. 
GUATTARI, Felix. Caosmose. São Paulo: Editora 34, 1992.

HAN, Byung-Chul. Agonia do Eros. Trad. Enio Paulo Giachini. Petrópolis: Vozes, 2017.

HAYMAN, David. The "Wake" in Transit. [S.I.]: Cornell Univ. Press, 1990.

INFORSATO, Erika Alvarez. Desobramento: constelações clínicas e políticas do comum. São Paulo, 2011. Tese (Doutorado) - Universidade de São Paulo.

JAKOBSON, Roman. Linguística e comunicação. São Paulo: Cultrix, 2014.

KHLÉBNIKOV, Velimir. KA. Trad. e notas Aurora Fornoni Bernardini. São Paulo: Perspectiva, 1977.

KRENAK, Ailton. Ideias para adiar o fim do mundo. São Paulo: Editora Companhia das Letras, 2019. Edição Kindle.

LAPOUJADE, David. As existências mínimas. São Paulo: N-1 Edições, 2017.

. Potências do tempo. São Paulo: N-1 Edições, 2017.

LAPPONI, Estela. Manifesto anti-inclusão [on-line]. Disponível em: $<$ http://estelapponi.blogspot.com/2012/05/anti-inclusao-manifesto.html>.

Acesso em: 7 jun. 2019.

LEYTON, Daina (org.). Educação e acessibilidade: experiências do Museu de Arte Moderna de São Paulo. São Paulo: Museu de Arte Moderna de São Paulo, 2018.

Paulo, 2015.

(org). Igual Diferente. São Paulo: Museu de Arte Moderna de São

- Entrevista com Daina Leyton no evento: Ibram Compartilhando Educação Museal em tempos de COVID-19. Disponível on-line em: <https://www.youtube.com/watch?v=-Ek20ck5Auk>. Acesso em: 17 jul. 2020.

(org.). Zine 20 anos Igual Diferente. Disponível em: <https://mam.org.br/publicacoes/livros/>. Acesso em: 17 jul. 2020.

LE FEUVRE, Lisa. Failure (Documents of Contemporary Art). [s.l.]: Whitechapel Gallery, 2010.

LIMA, Elizabeth Maria Freire de Araújo. Arte, clínica e loucura: território em mutação. São Paulo: Summus/Fapesp, 2009.

; PELBART, Peter Pál. Arte, clínica e loucura: um território em mutação.

História, Ciências, Saúde - Manguinhos, v. 14, n. 3, 2007, p.709-35.

MANNING, Erin. Always More than One: Individuation's Dance. [s.I.]: Duke University Press, 2013.

The minor gesture. [s.I.]: Duke University Press, 2016. 
MENDES, Julia Guimarães. Teatros do real, teatros do outro: os atores do cotidiano em cena contemporânea. São Paulo, 2017. Tese (Doutorado em Teoria e Prática do Teatro) - Escola de Comunicações e Artes, Universidade de São Paulo. doi:10.11606/T.27.2017.tde-31102017-145052.

NANCY, Jean-Luc. Being Singular Plural. [s.I.]: Stanford University Press, 2000.

OCUPAÇÃO Ueinzz, Sesc Paulista, 2011. [Catálogo]. São Paulo: Sesc, 2011. Disponível em: <https://issuu.com/varzeadesign/docs/ocupacaoueinzz>. Acesso em: 2 mar. 2020.

ORTIZ, Karin Zazo (ed.). Distúrbios neurológicos adquiridos: linguagem e cognição. São Paulo: Manole, 2005.

OURY, Jean. Utopie, atopie et eutopie. Chimère, n. 28, 1996, p.69-78.

. O coletivo. São Paulo: Hucitec, 2009.

PELBART, Peter Pál. Da clausura do fora ao fora da clausura. São Paulo: Brasiliense, 1989.

A nau do Tempo Rei: sete ensaios sobre o tempo da loucura. Rio de Janeiro: Imago, 1993.

A vertigem por um fio. São Paulo: lluminuras, 2000.

O corpo do Informe. In: GREINER, Christine; AMORIM, Cláudia. Leituras do corpo. São Paulo: Annablume, 2003.

2012. Palestra Peter Pál Pelbart [audiovisual]. Grupo OPOVOEMPÉ, 5 ago.
em: $<\mathrm{https}: / /$ www.youtube.com/watch?v=OJIWpsp2b6c\&t=264s>. Acesso em: 2 abr. 2020.

p.119-29. Disponível em: $<$ https://revistas.pucsp.br/PoliEtica/article/view/15206>. Acesso em: 11 mar. 2020.

Biblioteca de motins: leituras para incendiar o país. Palestra proferida na Flipei, 2019. Disponível em: <https://br.ivoox.com/es/peter-pal-pelbart-flipei2019-audios-mp3_rf_38403388_1.html>. Acesso em: 11 maio 2020.

Ensaios do assombro. São Paulo: N-1 Edições, 2019.

Pensar é estar à escuta da vida: o abecedário pandêmico de Deleuze. Curso ministrado em julho de 2020 no Atelier Paulista, São Paulo.

PRECIOSA, Rosane. Escrever/Balbuciar. Cadernos de Subjetividade, n. 12, 2010. 
Programa Vocacional-Projeto da Secretaria Municipal de Cultura, (publicação on-line). Revista Vocare, 2011. p. 45. Disponível em: <https://docero.com.br/doc/n515ne0>. Acesso em: 15 jul. 2020.

QUIJANO, Aníbal. Colonialidade do poder e classificação social. In: SANTOS, Boaventura de Sousa; PAULA, Meneses Maria. Epistemologias do sul. Coimbra: Cortez Editora, 2014.

QUILICl, Cassiano S. O ator-performer e as poéticas da transformação de si. São Paulo: Annablume, 2015.

RANCIÈRE, Jacques. A partilha do sensível. São Paulo: Editora 34, 2009.

. O inconsciente estético. São Paulo: Editora 34, 2009.

The Aesthetic Today. Palestra proferida na Yale School of Arquitecture de $2016 \quad$ [on-line]. Disponível em: <https://www.youtube.com/watch?v=w4RP87XN-dl>. Acesso em: 1 jun. 2019.

RIBEIRO, Martha. Corpos sublimes: o teatro-festa de Pippo Delbono II vangelo della teatralità. Sala Preta, v. 18, n. 1, 2018, p. 313-27.

ROLNIK, Suely. Cartografia sentimental. Porto Alegre: Editora da UFRGS, 2011.

. Esferas da insurreição: notas para uma vida não cafetinada. São Paulo: N-1 Edições, 2018.

SAFATLE, Vladimir. O circuito dos afetos: corpos políticos, desamparo e o fim do indivíduo. São Paulo: Autêntica, 2016.

SAKO, Maria. Companhia de Teatro Ueinzz mergulha no inconsciente. Helsingin Sanomat, 22 nov. 2009. Tradução John Laudenberger e Akseli Virtanen.

SÁNCHEZ, José A. A pesquisa artística e a arte dos dispositivos. [on-line]. Trad. Luciana Eastwood Romanolli. Questão de Crítica - Revista eletrônica de críticas e estudos teatrais, v. VIII, n. 65, ago. 2015. Disponível em: <http://www.questaodecritica.com.br/2015/08/a-pesquisa-artistica-e-a-arte-dosdispositivos/>. Acesso: 11 fev. 2020.

SANTOS, Boaventura de Sousa; PAULA, Meneses Maria. Epistemologias do sul. Coimbra: Cortez Editora, 2014.

SANTOS, Milton. A natureza do espaço: técnica e tempo, razão e emoção. São Paulo: Edusp, 2002.

SARRAZAC, Jean-Pierre (org.). Léxico do drama moderno e contemporâneo. São Paulo: CosacNaify, 2012.

SHATTUCK, Roger. The Banquet Years: the Origins of the Avant Garde in France, 1885 to World War I: Alfred Jarry, Henri Rousseau, Erik Satie [and] 
Guillaume Apollinaire. [S.I.]: Vintage, 1968.

SEARLE, John R. Expressão e significado: estudos da teoria dos atos da fala. São Paulo: Martins Fontes, 2002.

SCHECHNER, Richard; APPEL, Willa. By Means of Performance intercultural studies of theatre and ritual. Cambridge: Cambridge University Press, 1997.

SCHULZ, Bruno. Lojas de canela. São Paulo: CosacNaify, 2014.

SILVA, Lidia Olinto do Valle. Conjunctio oppositorum e o parateatro de Jerzy Grotowski e companhia (1970-1982). Campinas, 2016. Tese (Doutorado em Teatro, Dança e Performance) - Instituto de Artes, Universidade Estadual de Campinas. Disponível em: <http://repositorio.unicamp.br/bitstream/REPOSIP/325730/1/Silva_LidiaOlintoD oValle_D.pdf>. Acesso em: 20 abr. 2020.

SONTAG, Susan. Against Interpretation: And Other Essays. [S.I.]: Macmillan, 1966.

THOMSON, Rosemarie Garland. Extraordinary Bodies: Figuring Physical Disability in American Culture and Literature. [S.I.]: Columbia University Press, 2017.

VIEIRA, Cristiane Paoli. Movimento-imagem-ideia - o percurso de uma prática. São Paulo, 2016. Tese (Doutorado) - Universidade de São Paulo.

WHITEHEAD, Alfred North. Adventures of ideas. [S.I.]: The Free Press, 1967.

YOUNG, Stella. Eu não sou sua inspiração, muito obrigada [on-line]. Palestra no TED, 2014. Disponível em:

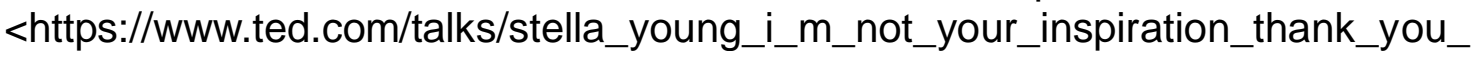
very_much?languageopt-br>. Acesso em: 1ํ jun. 2019.

ZLOTNIC, Sergio. Nunca preste atenção! [on-line]. SP Escola de Teatro, 5 nov. 2014. Disponível em: <https://www.spescoladeteatro.org.br/noticia/nuncapreste-atencao/>. Acesso em: 3 jul. 2020.

Nunca preste atenção! [on-line]. SP Escola de Teatro, 5 ago. 2014. Disponível em: <http://www.spescoladeteatro.org.br/noticia/nunca-presteatencao/>. Acesso em: 2 jun. 2019.

Palavra é lugar [on-line]. SP Escola de Teatro, 6 abr. 2015. Disponível em: < https://www.spescoladeteatro.org.br/noticia/palavra-e-lugar/>. Acesso em: 4. abril. 2020.

Anamnese [on-line]. SP Escola de Teatro, 2 out. 2017a. Disponível em: $<$ http://www.spescoladeteatro.org.br/coluna/anamnese/s. Acesso em: 2 jun. 2019.

É preciso emburrecer [on-line]. SP Escola de Teatro, 2 out. 2017b. 
Disponível em: <http://www.spescoladeteatro.org.br/coluna/e-precisoemburrecer/>. Acesso em: 2 jun. 2019.

. Criar é matar a morte [on-line]. SP Escola de Teatro, 2 out. 2017c. Disponível em: <http://www.spescoladeteatro.org.br/coluna/criar-e-matarmorte/>. Acesso em: 2 jun. 2019.

As palavras e as coisas! [on-line]. SP Escola de Teatro, 2 out. 2017d. Disponível em: <http://www.spescoladeteatro.org.br/coluna/e-mail-zzzzlotgmailcom-as-palavras-e-as-coisas/>. Acesso em: 2 jun. 2019.

Do outro lado do oceano [on-line]. SP Escola de Teatro, s.d. Disponível em: <http://www.spescoladeteatro.org.br/noticias/ver.php?id=5542>. Acesso em: 7 jun. 2019.

ZOURABICHVILI, François. O vocabulário de Deleuze [on-line]. Trad. André Telles. Rio de Janeiro: Centro Interdisciplinar de Estudo em Novas Tecnologias e Informação, 2004. Disponível em: <http://escolanomade.org/wpcontent/downloads/deleuze-vocabulario-francoiszourabichvili.pdf?fbclid=IwAR1gNi4QleCGRniZ8NkPwJbqXt2dL52oJ6xMn7Yqz AQe7efHdquh6JF1SE8>. Acesso em: 11 maio 2020. 